PABLO BIONDI

\title{
OS DIREITOS HUMANOS E SOCIAIS E O CAPITALISMO: \\ ELEMENTOS PARA UMA CRÍTICA
}

São Paulo

2012 


\section{PABLO BIONDI}

\section{OS DIREITOS HUMANOS E SOCIAIS E O CAPITALISMO: ELEMENTOS PARA UMA CRÍTICA}

Dissertação apresentada à Universidade de São Paulo para obtenção do título de Mestre em Direito

Área de concentração:

Direitos Humanos

Orientador: Professor Doutor Marcus Orione Gonçalves

Correia

São Paulo 
Autorizo a reprodução e divulgação total e parcial deste trabalho, por qualquer meio convencional ou eletrônico, para fins de estudo e pesquisa, desde que citada a fonte.

Catalogação da Publicação

Faculdade de Direito da Universidade de São Paulo

BIONDI, Pablo.

Os direitos humanos e sociais e o capitalismo : elementos para uma crítica / Pablo Biondi ; orientador Marcus Orione Gonçalves Correia. - São Paulo, 2012. $184 \mathrm{fl}$

Tese (Mestrado) - - Universidade de São Paulo, 2012.

1. Direitos Humanos - individuais e sociais. 2. Capitalismo. 3. Crítica marxista. 
Nome: BIONDI, Pablo

Título: Os direitos humanos e sociais e o capitalismo: elementos para uma crítica

Dissertação apresentada à Faculdade de Direito da Universidade de São Paulo para a obtenção do título de Mestre em Direito

Aprovado em:

Banca Examinadora

Prof. Dr. Instituição:

Julgamento: Assinatura:

Prof. Dr. Instituição:

Julgamento: Assinatura:

Prof. Dr. Instituição:

Julgamento: Assinatura: 
Dedico esta obra aos moradores do Pinheirinho, cuja saga de coragem e ousadia revela, pelo seu lado triste, a que serve o direito. Mas que novos Pinheirinhos apareçam! Que os despossuídos possam erguer novas barricadas de esperança contra a covardia dos donos do mundo e contra as ordens judiciais por eles encomendadas. 


\section{AGRADECIMENTOS}

Quando penso na enorme quantidade de pessoas a quem devo agradecimentos, sou tomado por um sentimento ambíguo. De um lado, alegra-me pensar em cada uma delas e no quanto foram e são importantes para mim. De outro, angustia-me a necessidade de me ater, neste espaço limitado, a referências singelas que não dão conta de revelar a importância de cada uma dessas pessoas nos caminhos que percorri.

Parentes, amigos, companheiros de luta e professores contribuíram decisivamente para que eu chegasse à finalização de uma dissertação de mestrado, influindo, ainda, nos rumos teóricos de minha pesquisa e na escolha da causa com a qual ela mantém uma ligação inseparável. Causa esta que, apesar de exigir tanto de nós, "nos dá a maior das felicidades, a consciência de participar da construção de um futuro melhor, de levar sobre nossas costas uma partícula do destino da humanidade e de não viver em vão". Palavras certeiras de Leon Trotsky.

Quero agradecer, em primeiro lugar, à minha estimada família: Leonor, Joyce, Leyla e Nelson (in memoriam). Sem ela, eu nada seria. Recebi dela, com muitos esforços e sacrifícios, uma instrução de qualidade que me preparou para os desafios da vida. Mas, acima de tudo, ela me deu educação, e no sentido mais completo e humano que se possa dar ao termo - o que envolve, naturalmente, o afeto, o amparo e a confiança. Devo a ela todas as condições e circunstâncias que me permitiram estudar e que clarearam minha visão para os caminhos pelos quais enveredei. Devo-lhe, ainda, uma formação de caráter que me deu as forças necessárias para nadar contra a corrente sempre que foi preciso. Graças a minha família, aprendi que temos que nos manter firmes para entrar pela porta estreita, mesmo que as portas amplas se apresentem como mais convidativas.

Agradeço ao meu orientador, o professor Marcus Orione Gonçalves Correia, talvez o único docente da pós-graduação da FDUSP politicamente disposto a orientar uma dissertação com propósitos de crítica radical. Seu acompanhamento atencioso, em notável harmonia com a mais ampla liberdade acadêmica, permitiu que este trabalho navegasse por águas seguras. Suas correções e os cuidados para os quais direcionou minha atenção foram fundamentais. Sou muito grato também pela confiança que me foi depositada e pela oportunidade de ser seu orientando uma experiência sem igual. $\mathrm{O}$ aprendizado em suas aulas, dirigidas pela mais rica 
dialética, e a participação no seu grupo de estudos, verdadeira escola de saber crítico, alçaram-me a vôos dos quais não me julgava capaz.

Agradeço ao professor Márcio Bilharinho Naves pelas observações pertinentes na banca de qualificação, pelo exame rigoroso do texto, pelas correções que fez e pelo incentivo generoso. E, em especial, pelo material bibliográfico de elevada qualidade que tão graciosamente me foi fornecido.

Agradeço ao professor Alysson Leandro Barbate Mascaro por todo o seu aporte teórico, pelas orientações que culminaram numa importante reestruturação dos capítulos da obra, pelas indicações bibliográficas imprescindíveis e por se colocar, com a amabilidade que lhe é peculiar, à disposição para ajudar.

Agradeço aos amigos e colegas do grupo de estudos do professor Marcus Orione Gonçalves Correia pelo desenvolvimento coletivo de que fazemos parte e por nossos debates tão proveitosos. Divido com eles os méritos que este trabalho possa ter, eximindo-os, no entanto, das imperfeições decorrentes de minhas insuficiências. Faço questão de citar cada um desses colegas: Flávio Batista, Thiago Barison, Rafael Menezes, William Castanho, Jonnas Esmeraldo, Danilo Uler e Aton Fon. Particularmente, agradeço ao Flávio, por partilhar seus conhecimentos comigo e com os demais, e ao William, pelas nossas instigantes conversas de almoço.

Dos meus tantos e tão valiosos(as) amigos(as) da faculdade, devo citar aqueles e aquelas com quem mais discuti os temas de que trato nesta pesquisa, e isto graças à maravilhosa convivência com que me presentearam. Foram anos intensos, marcados por uma solidariedade de experiências que me liga a esses(as) amigos(as) para sempre. São eles(as): Vinícius Mota, Renan Quinalha, Luiz Mendonça, Gabriel Muniz, Marcos Minari, Thiago Leal, João Bosco, Danilo Queiroz, Rafael Miranda, Vitor Polacchini, Regina Vieira, Ana Navarrete, Rafaela Barbosa, Lígia Trindade, Talita Melo, Isadora Brandão, Flávia Annenberg, Flávio Prol, Nayara Meira, Paulo Yamamoto, Ana Bianchi, Renata Elias, Esther Ambrozio, Ana Flora Pontes e Leonardo Lima. Gostaria de agradecer, destacadamente, ao "Vini”, por manter comigo laços de fraternidade tais que o tornam um amigo de todas as horas e por cada uma das lições de vida que me apresentou; ao Renan, por ser uma referência teórico-prática inspiradora e por todo apoio que dedicou a mim; e ao "Minari", por nossas divertidas incursões filosóficas e pelas palavras de amizade e sabedoria que me estimularam. 
Há ainda uma lista de pessoas a quem devo um agradecimento muito especial, na medida em que aprendi muito com cada uma delas e na medida em que partilho com elas os mesmos ideais e práticas. Estou politicamente irmanado a elas sob o estandarte da IV Internacional, uma bandeira sem nódoas que, ao não capitular ao revisionismo social-democrata e ao rechaçar a degeneração stalinista, defendeu e ainda defende o programa libertário e igualitário de Marx até as últimas consequências. Cito os(as) companheiros(as) de jornada que me são mais próximos: Aleksei Neves, Israel Luz, Heitor Mota, Gabriela Hipólito, Débora Manzano, Thiago Clemente, Tairo Esperança, Ticiane Natale, Alexandre De Chiara, Riccardo Silva, Ana Lucia Marchiori, Luís Cláudio Silva, Bruno Colares, Alberto Albiero Jr., Fabiana do Amaral, Cláudio Rennó, Julia Eid, Zenilda Vital, Regiane Moura, Gilberto de Souza e Américo Gomes. Agradeço enfaticamente ao meu grande amigo Aleksei, ao lado de quem vivi os melhores momentos do meu engajamento e com quem desenvolvi uma relação de estima e confiança muito peculiar, e à Ana Lucia, pelos incentivos constantes e pelos ensinamentos que colho de suas intervenções e posturas.

Last but not least, agradeço a Thaísa Ribeiro, Simone Henrique, Tatiana Waldman e Denise Moretti pela reconfortante amizade, pela agradável companhia ao longo do curso de pós-graduação e pelo intercâmbio de aprendizados.

A cada uma dessas pessoas citadas, estendo minha mais sincera gratidão e reconhecimento por tudo. 
"A crítica arrancou as flores imaginárias dos grilhões, não para que o homem os suportem sem fantasias ou consolo, mas para que lance fora os grilhões e a flor viva brote".

"O direito jamais pode ser mais elevado do que a estrutura econômica da sociedade e o desenvolvimento cultural correspondente". 


\section{RESUMO}

BIONDI, P. Os direitos humanos e sociais e o capitalismo: elementos para uma crítica. 2012. 184 f. Tese (Mestrado) - Faculdade de Direito, Universidade de São Paulo, São Paulo, 2012.

Este estudo propõe uma ligação decisiva entre o capitalismo e os assim chamados direitos humanos e sociais. O objetivo é provar que o desenvolvimento histórico dos direitos humanos, considerando sua primeira dimensão e sua segunda dimensão, não é baseado no desenvolvimento do espírito humano e da consciência universal, mas sim no processo capitalista de produção e reprodução social. Ao se seguir um caminho teórico marxista, é possível perceber que toda a forma jurídica, até mesmo os direitos humanos, está profundamente comprometida com uma estrutura capitalista de sociedade. Em adendo, este fato implica consequências importantes para todos os programas políticos e perspectivas reformistas. Os direitos civis e políticos, tanto quanto os direitos sociais, são parte de um maquinário burguês que faz do direito um instrumento de exploração e preservação do status quo, apesar do progresso relativo que eles podem trazer com eles. O Estado de Direito é apenas uma maneira particular pela qual o Estado burguês, em tempos de normalidade, emprega sua violência. $E$ as políticas de bem-estar social não são nada além de uma intervenção estatal para apoiar o ciclo de acumulação do capital conforme necessidades concretas (e políticas). Não há nenhum tipo de esclarecimento, bondade ou senso de decência humana nos direitos relacionados à democracia liberal e às instituições de bem-estar social, mas sim contingências de determinados momentos da luta de classes e da dinâmica econômica de reprodução sob o sistema capitalista. A verdadeira emancipação só é viável pelo fim das classes sociais, um difícil horizonte que começa com uma estratégia socialista. E quanto mais a revolução socialista modifica as relações de produção para estabelecer o controle social pela classe trabalhadora, tanto menor é a hegemonia da forma jurídica sobre a vida, porque o direito perece junto com o fim da produção e da circulação de mercadorias. A luta pelo socialismo como a luta por um novo e superior tipo de vida civilizada que nenhum dos direitos humanos poderia prover à humanidade.

Palavras-chave: Direitos humanos - individuais e sociais. Capitalismo. Crítica marxista. 


\begin{abstract}
BIONDI, P. Human and social rights and capitalism: elements for a critique. 2012. 184 f. Tese (Mestrado) - Faculdade de Direito, Universidade de São Paulo, São Paulo, 2012.
\end{abstract}

This study proposes a critical link between capitalism and the so-called human and social rights. The objective is to prove that the historical development of human rights, considering their first dimension and their second dimension, is not based on the development of the human spirit or of a universal consciousness, but on capitalist process of social production and reproduction. By following a marxist theoretical path, it is possible to realize that all juridical form, even human rights, is deeply compromised with a capitalist structure of society. In addition, this fact implicates important consequences for all reformist political programs and perspectives. Civil and political rights, as much as social rights, are part of a bourgeois machinery which turn law into an instrument of exploitation and preservation of status quo, despite the relative progress they may bring with themselves. The rule of Law is only a particular manner by which bourgeois state, in times of normality, employs its violence. And the policies of welfare are nothing but a state intervention to support the cycle of accumulation of capital according concrete (and political) necessities. There is not any sort of enlightenment, kindness or sense of human decency in the rights related to liberal democracy and the institutions of welfare state, but only contingences from a determined moment of struggle of class and economical dynamics of reproduction under capitalist system. A true emancipation is only viable by the end of social classes, a difficult horizon that begins with a socialist strategy. And the more a socialist revolution changes the relations of production in order to establish a social control by working class, the lesser is the hegemony of the juridical form over life, because law perishes tied to the end of production and circulation of commodities. The struggle for socialism reveals itself as a struggle for a new and superior kind of civilized life which none of the human rights could provide to mankind.

Keywords: Human rights - individual and social ones. Capitalism. Marxist critique 


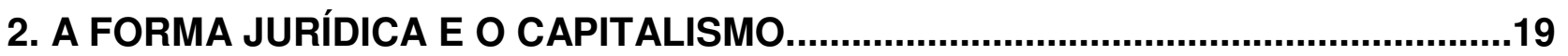

2.1. O conceito de modo de produção......................................................................19

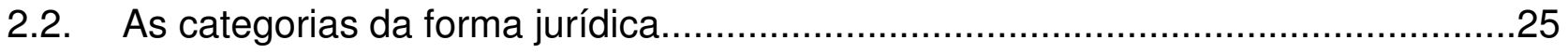

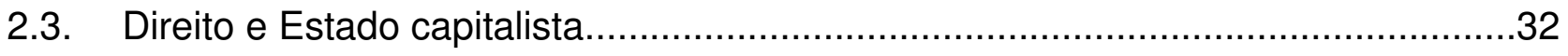

3. O MOdO DE PRODUÇÃo CAPITALISTA E OS DIREITOS hUMANOS

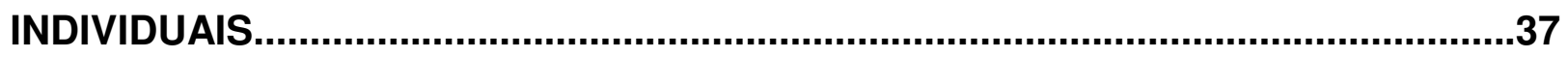

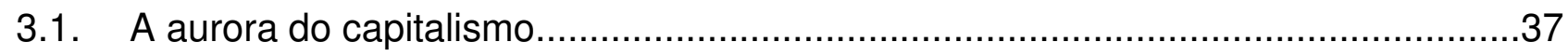

3.2. A natureza de classe dos direitos civis e políticos....................................................

3.3. As liberdades democráticas e o Estado de Direito................................................59

3.4. Um exemplo prático: o espaço dos conflitos sociais na democracia liberal.............73

4. O MODO DE PRODUÇÃo CAPITALISTA E OS DIREITOS hUMANOS

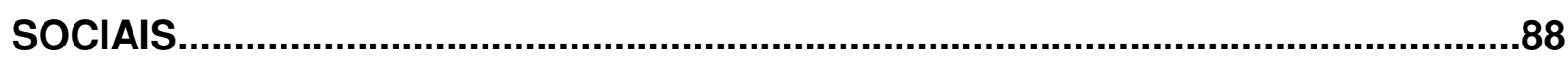

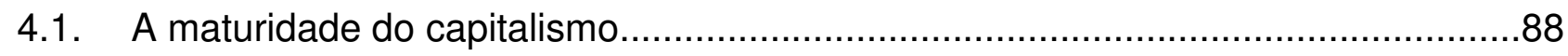

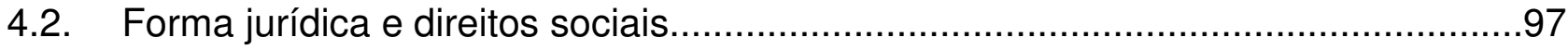

4.3. Luta de classes, reprodução econômica e direitos sociais.................................106

4.4. Um exemplo prático: o direito do trabalho ..........................................................125

5. O SOCIALISMO COMO ALTERNATIVA SUPERIOR AOS DIREITOS

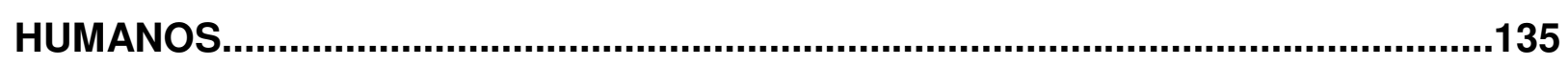

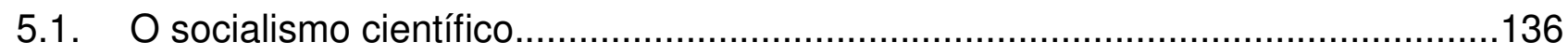

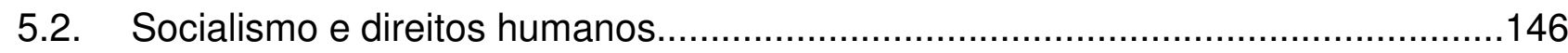

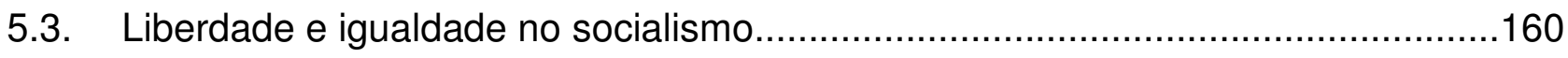

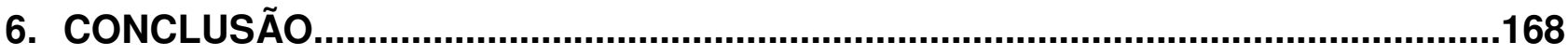

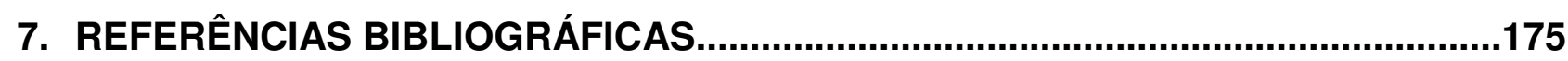




\section{INTRODUÇÃO}

Os direitos humanos, em regra, são concebidos como a glória da civilização, como sua obra-prima. É como se a sua evolução revelasse a própria evolução do espírito humano, com a crescente percepção, pela humanidade, de seu potencial e beleza imanentes.

Esta concepção, amplamente espraiada no mundo jurídico, encontra-se melhor concretizada no pensamento de Fábio Konder Comparato, para quem o fundamento axiológico dos direitos humanos deriva do aperfeiçoamento da idéia de essência humana, isto é, de um atributo - a humanidade - comum a todos os indivíduos, sem relação com qualquer concretude histórica e social. A evolução desta ideia teria se operado em frentes múltiplas (religião, filosofia e ciência), num movimento culturalmente amplo de busca pela dignidade do homem. Faremos um resumo ${ }^{1}$ breve e despretensioso da teoria citada para, a partir dele, apresentar as inquietações que fundamentam a escolha de nosso tema.

$\mathrm{Na}$ religião, o aludido movimento evolucionista começa com a proclamação de um Deus que contempla todos os povos, partindo do profeta Isaías e se aprofundando com o cristianismo. O homem abstrato e universal estaria presente numa das epístolas do apóstolo Paulo, em que se afirmava que, perante Cristo, não há divisões de credo, gênero ou raça.

$\mathrm{Na}$ filosofia, consolidou-se a noção de dignidade humana e de direitos inatos ao homem, independentemente de sua nacionalidade. Isto teve início na Grécia Antiga, com os estóicos, que pensavam os homens como sendo todos filhos de Zeus e, portanto, portadores de uma condição comum. Mais adiante, nos primórdios da Idade Média, Boécio se apropriou do conceito grego de pessoa para indicá-lo como o substrato de todos os homens, como o conteúdo da essência da humanidade. E finalmente, a Modernidade concebeu o homem como ente racional, e o nome mais relevante para o fundamento axiológico dos direitos humanos foi Kant. Na perspectiva deste filósofo, o homem é uma figura dotada de dignidade graças à sua autonomia. Neste sentido, ele é um ser singular, o único apto a construir seu próprio destino. E é por ser singular que ele não pode ser trocável como uma coisa, não pode possuir um preço, devendo, ao contrário, ser respeitado como pessoa.

\footnotetext{
${ }^{1}$ Vide a introdução da obra: COMPARATO, Fábio Konder. A afirmação histórica dos direitos humanos, 7a. ed.. São Paulo: Saraiva, 2010.
} 
Este respeito é a fonte do imperativo categórico pelo qual o homem só deve ser fim em si mesmo, nunca um meio para se atingir um fim. A valorização da imagem do homem (inclusive no reconhecimento de seus direitos básicos) apresenta-se como um objetivo autojustificado e autorreferenciado.

Na ciência, por fim, o evolucionismo de Darwin também destacou o caráter único do homem como o último horizonte da evolução dos seres vivos. Nenhuma outra espécie é capaz de governar a si mesma e de governar as demais, ou de desenvolver a arte e a própria ciência. Nenhuma outra é capaz de estender os domínios de seu império pela imensidão do globo. Além disso, os estudos na genética comprovaram que cada pessoa carrega consigo uma identidade biológica própria, embora sem prejuízo de seu pertencimento à espécie humana. Este fato fortaleceria o conceito de dignidade, cuja origem remonta à filosofia.

Para Comparato, o apogeu da afirmação dos direitos humanos se dá na Era Moderna, com as bandeiras ideológicas do mote da Revolução Francesa (evento central no referido período): Liberdade, Igualdade e Fraternidade. A mais acabada expressão da essência humana se positivaria no anúncio desses princípios, cuja efetivação iniciava pela queda dos óbices do Antigo Regime, isto é, do conjunto de suas instituições feudais. Antes das conquistas do século XVIII, não se poderia falar propriamente em direitos humanos na medida em que os homens eram tidos como desiguais desde o nascimento (as teorias desenvolvidas na Antiguidade e na Idade Média não tiveram repercussão social prática). Os privilégios estamentais cristalizavam papéis determinados às pessoas de acordo com uma hierarquia rígida, o que se opunha a qualquer pretensão de direitos numa perspectiva de universalidade. A ruptura com estes arcaísmos ocorreria sob influência do iluminismo, quando se percebeu que todos os seres humanos encontram na razão um elemento comum, e que esta mesma razão não admite desigualdades justificadas pela natureza ou pela divindade.

Os ideais iluministas colocaram a tríade da liberdade, igualdade e fraternidade como oriunda da razão humana e, portanto, como causa primeira dos direitos inerentes aos homens. Logo, esses três princípios estariam agraciados com um alcance universal. Acompanhariam o homem independentemente do espaço e do tempo, como insinuou a Declaração dos Direitos do Homem e do Cidadão. Seriam direitos naturais e inerentes à humanidade, conforme se registrou na tradição 
jusnaturalista. A cada um destes elementos corresponde uma geração ou dimensão dos direitos humanos, cabendo-nos tratar das duas primeiras.

A liberdade que se afirmou a partir da independência dos EUA e da Revolução Francesa foi a chamada "liberdade dos modernos", para se usar a expressão de Benjamin Constant. Ao contrário da "liberdade dos antigos", em que prevalece a participação no espaço público, nas decisões importantes da polis, a liberdade reconhecida no século XVIII era radicalmente negativa. Consubstanciavase ela na imposição de proibições ao Estado, que só poderia obrigar os cidadãos por normas produzidas por seus representantes eleitos democraticamente.

A igualdade, em seu turno, restringiu-se inicialmente ao âmbito formal, declarando-se todos os homens como cidadãos, isto é, como indivíduos inseridos num igual patamar social e jurídico (igualdade perante a lei). Os votos de cada cidadão possuem o mesmo peso político: um voto por cabeça, sem qualquer discriminação.

Não obstante este avanço, as condições de vida da maioria não melhorariam com a mera abstenção do Estado liberal, adstrito a funções limitadas e rígidas para não espoliar os cidadãos. Seria necessário pensar o homem não só como ser abstrato, como indivíduo atomizado e independente, mas também como ser concreto, com carências determinadas. O homem não existe apenas como cidadão; ele é também trabalhador, deficiente, idoso, criança etc. E é justamente esta constatação que explicaria a justiça dos direitos econômicos e sociais: junto ao igual tratamento dos iguais na exata proporção de sua igualdade, projeta-se, como complemento irrenunciável, o desigual tratamento dos desiguais na exata proporção de sua desigualdade.

Nisto consiste, de maneira muito enxuta, o pensamento convencional acerca dos direitos humanos, apesar de uma ou outra nuança, dependendo do autor. Ocorre que, infelizmente, não podemos nos contentar com esta caminhada idílica que começa na Antiguidade em direção à liberdade e à igualdade atuais. Uma única questão basta para derrubar esta teoria, ou ao menos para abalar sua confortável convicção:

É somente em um momento muito preciso da história, sob uma estrita determinação social, exatamente quando as relações de produção capitalistas vão se constituindo, que a liberdade e a igualdade aparecem como se fossem inerentes à própria natureza do homem. Por que essas categorias, por tanto tempo ignoradas, por tanto tempo negadas, agora se 
tornam tão imprescindíveis para a própria identificação da humanidade do homem ${ }^{2}$ ?

O que Márcio Bilharinho Naves faz, como marxista, é localizar historicamente o fenômeno do direito e suas categorias, buscando as determinações que o caracterizam. A liberdade e a igualdade, figuras fundamentais do direito, e em especial dos direitos humanos, têm uma história por trás de si. Não são dados a priori progressivamente captados pelo conhecimento humano. Não são tesouros de verdade absoluta que estiveram enterrados pela eternidade até que, cessada a ignorância dos homens, enfim viessem à tona. Aqui, impõe-se a conclusão de Marx acerca do caráter do fenômeno jurídico perante o todo social, contrariamente a qualquer leitura impregnada de um viés idealista:

\begin{abstract}
Minhas investigações me conduziram ao seguinte resultado: as relações jurídicas, bem como as formas do Estado, não podem ser explicadas por si mesmas, nem pela chamada evolução geral do espírito humano; essas relações têm, ao contrário, suas raízes nas condições materiais de existência, em suas totalidades, condições estas que Hegel, a exemplo dos ingleses e franceses do século 18 , compreendia sob o nome de 'sociedade civil'. Cheguei também à conclusão de que a anatomia da sociedade burguesa deve ser procurada na Economia Política ${ }^{3}$.
\end{abstract}

Está claro a esta altura que as elaborações usuais sobre direitos humanos carregam com elas, ainda que não declaradamente ou em termos exatos, o pecado original do idealismo. Mesmo com a vasta erudição de um Fábio Konder Comparato, não se ultrapassa o limitado horizonte da evolução do espírito humano. Ignora-se a estreita ligação entre capitalismo e direito que se verifica nas tramas do tecido da história.

É a partir da crítica ao idealismo nos direitos humanos, então, que nossa proposta de investigação busca um paralelo com o desenvolvimento do capitalismo. Adotaremos, pela necessidade de delimitação, um recorte que contemplará apenas os direitos das duas primeiras "dimensões", ou seja, os direitos civis e políticos seguidos dos direitos econômicos e sociais. Haveremos de demonstrar ainda, ao longo do estudo, que esta divisão é ideológica, e que a forma jurídica e seu caráter

\footnotetext{
${ }^{2}$ NAVES, Márcio Bilharinho. Direito, circulação mercantil e luta social. In: ALVES, Alaôr Caffé et al. Direito, sociedade e economia: leituras marxistas. Barueri: Manole, 2005, p. 26. Impressiona como, em querelas como esta, pode haver mais lucidez e clareza intelectual em uma pergunta do que em quinhentas respostas.

${ }^{3}$ MARX, Karl. Contribuição à crítica da economia política, 2ª. ed.. Tradução de Florestan Fernandes. São Paulo: Expressão Popular, 2008, p. 45. Daremos seguimento a este excerto oportunamente.
} 
não mudam, quer se trate das liberdades abstratas do liberalismo, quer se trate das prestações do Estado providência.

Apresentemos agora nosso itinerário, apontando como ele contemplará os direitos humanos em sua forma e conteúdo ${ }^{4}$.

Começaremos investigando a relação do capitalismo com a forma jurídica, já que os direitos humanos efetivamente integram a dinâmica da ordem jurídica e da reprodução social, e isto nos termos da localização que a estrutura da sociedade capitalista lhes reserva. Disto advêm importantes discussões: como se opera a separação dos níveis no interior de um modo de produção (estrutura e superestruturas) e como a superestrutura jurídica, em particular, apresenta suas categorias fundamentais (sujeito de direito e relação jurídica). Também terá lugar, neste capítulo inicial, uma rápida reflexão sobre o Estado, tendo como foco o fecho do esquema da crítica marxista do direito.

No capítulo posterior, dedicar-nos-emos aos direitos humanos individuais. Comentaremos a formação histórica do capitalismo para dela extrair a base dos direitos civis e políticos, o que nos permitirá compreender as características e tendências das liberdades democráticas e do Estado de Direito, que não são mais do que o conteúdo daqueles direitos. Tudo isto tendo em vista a natureza do Estado capitalista, elemento imprescindível para se indagar sobre o espaço das lutas sociais na democracia liberal, localizando em seu interior as pressões no sentido de sua negação e degeneração.

Ulteriormente, chegaremos aos direitos humanos sociais. Cumpre situá-los no contexto do amadurecimento do capitalismo, pensando-os conforme o esquema da forma jurídica e agregando ponderações econômicas (reprodução do sistema) e políticas (luta de classes), o que levará a duas questões: qual o espaço dos direitos sociais no capitalismo e se eles são anticapitalistas, como alguns propõem (tácita ou expressamente), seja no conteúdo ou na forma. Empregaremos como exemplo prático o direito do trabalho.

O último capítulo da obra é reservado para apresentar o socialismo como uma alternativa superior aos direitos humanos, desmentindo a opinio communis que vê

\footnotetext{
${ }^{4}$ Já no capítulo primeiro, utilizaremos o arsenal crítico de Eugeny Pasukanis para identificar no direito a presença de caracteres que compõem uma forma jurídica cuja compleição independe das leis, decretos e outras normas estatais. Nosso eixo de análise encontra-se na principal obra do jurista soviético: PASUKANIS, Eugeny B. A teoria geral do direito e o marxismo. Tradução de Paulo Bessa. Rio de Janeiro: Renovar, 1989.
} 
neles o último estágio possível da civilização. Será necessário, então, explicar em que consiste o socialismo, afastando-o das experiências malsucedidas que falaram em seu nome sem lhe fazer jus, como é o caso da União Soviética. Caberá, a seguir, examinar a localização categorias jurídicas numa sociedade socialista e contrastar as noções capitalistas de liberdade e igualdade com as noções revolucionárias de liberdade e igualdade.

Eis aí o percurso da crítica dos direitos humanos que queremos realizar. Feito todo este trajeto, esperamos ter amealhado elementos para uma conclusão sobre a natureza social do objeto de estudo escolhido, o que nos autorizará, inclusive, a formular uma caracterização sobre os horizontes reformistas que apostam no direito (e nos direitos humanos acima de tudo) como um instrumento de emancipação social. 


\section{A FORMA JURÍDICA E O CAPITALISMO}

A exploração do homem pelo homem é uma constante, mas sua forma mudou, é menos 'grosseira', dissimula-se com os cenários da igualdade, recobre-se com um verniz de boas maneiras ${ }^{5}$.

Leon Trotsky

Neste capítulo, nosso desafio será o de apurar os liames entre capitalismo e direito, delineando os parâmetros de discussão que nortearão esta obra. Vimos em Marx que as raízes das relações jurídicas e do Estado encontram-se nas condições materiais de existência da sociedade. Caberá agora esmiuçar os desdobramentos desta percepção conforme o arcabouço teórico oferecido pelo marxismo.

\subsection{O conceito de modo de produção}

Não se pode aproximar direito e capitalismo, numa leitura marxista, sem mencionar a relação entre estrutura e superestrutura, a qual é objeto de inúmeras incompreensões. Corriqueiramente se insinua que o materialismo histórico consiste em propor apenas que a economia determina tudo, e que as outras dimensões da existência social são meros reflexos dela. Nosso estudo enfrentará esta incompreensão, assumindo a tarefa de lançá-la por terra.

Quando um marxista fala de uma estrutura capitalista e de uma superestrutura jurídica, está pressuposta a ideia de um modo de produção capitalista, isto é, de um todo organizado e hierarquizado a partir de uma estrutura econômica. Localizemos em Marx como estão dispostos os elementos em discussão:

O resultado geral a que cheguei e que, uma vez obtido, serviu-me de guia
para meus estudos, pode ser formulado, resumidamente, assim: na
produção social da própria existência, os homens entram em relações
determinadas, necessárias, independentes de sua vontade; essas relações
de produção correspondem a um grau determinado de desenvolvimento de
suas forças produtivas materiais. A totalidade dessas relações de produção
constitui a estrutura econômica da sociedade, a base real sobre a qual se
eleva uma superestrutura jurídica e política e à qual correspondem formas
sociais determinadas de consciência. O modo de produção da vida material
condiciona o processo de vida social, política e intelectual. Não é a

${ }^{5}$ TROTSKY, Leon. Questões do modo de vida. A moral deles e a nossa. Tradução de Diego Siqueira e Daniel Oliveira. São Paulo: Instituto José Luís e Rosa Sundermann, 2009, p. 51. 
consciência dos homens que determina o seu ser; ao contrário, é o seu ser social que determina sua consciência ${ }^{6}$.

Nesta passagem, Marx explica que as comunidades humanas se organizam numa totalidade (modo de produção), mas que esta totalidade é formada por níveis ou instâncias. Em outras palavras, o pensador alemão "não pode contentar-se em indicar-nos que a sociedade é um todo: ele acrescenta que este todo é estruturado"”. Os modos de produção da vida material realizam-se em níveis diferentes, que guardam entre si uma hierarquia ontológica, o que não quer dizer, de modo algum, que um seja uma "sombra" do outro. A vida material da humanidade é produzida tanto na "estrutura econômica da sociedade" como na "superestrutura jurídica e política" que se eleva sobre ela, embora as primeiras e principais determinações se encontrem na primeira. E não poderia ser de outra maneira, pois o intercâmbio com a natureza pelo trabalho, atividade pela qual os homens se abrigam das necessidades elementares, precede a feitura da arte, da religião, da política e do próprio direito. Colocando de outra forma, a produção da vida material pelo trabalho é um eixo que, enquanto tal, não exaure a realidade na sua inteireza, mas lhe molda as bases, o que é muito diferente. Marx e Engels enxergam a referida produção como "o primeiro ato histórico", como sendo "uma condição fundamental de toda a história, que ainda hoje, assim como há milênios, tem de ser cumprida diariamente, a cada hora, simplesmente para manter os homens vivos".

Portanto, é preciso conceber o modo de produção como um conjunto no qual se produz a vida social ${ }^{9}$, a despeito da imagem de um edifício, que costuma induzir a enganos (como se só a base do prédio importasse de fato). Com efeito, a base é o mais importante, mas os "andares" também compõem o edifício, ainda que com um estatuto ontológico inferior em termos de determinação causal. Ninguém negará que o direito é também causa, e não só um efeito. Contudo, inserido que está no modo

\footnotetext{
${ }^{6}$ MARX, Contribuição à crítica da economia política. Op. Cit., 2008, p. 45. Aqui está a continuidade do trecho prometida anteriormente. Optamos por seccioná-lo somente para melhor atender ao curso da exposição.

${ }^{7}$ MIAILLE, Michel. Introdução crítica ao Direito, 3. ${ }^{\text {a }}$ ed.. Tradução de Ana Prata. Lisboa: Estampa, 2005, p. 73.

${ }^{8}$ MARX, Karl; ENGELS, Friedrich. A ideologia alemã: crítica da mais recente filosofia alemã em seus representantes Feuerbach, B. Bauer e Stirner, e do socialismo alemão em seus diferentes profetas. Tradução de Rubens Enderle, Nélio Schneider e Luciano Cavini Martorano. São Paulo: Boitempo, 2007, p. 33

9 "O modo de produção não tem de maneira nenhuma o significado unilateral económico que se the costuma dar: é o conceito que designa a maneira como uma sociedade se organiza para produzir a vida social" (MIAILLE, Op. Cit., 2005, p. 68).
} 
de produção, a causalidade advinda do fenômeno jurídico é muito menor do que a causalidade advinda imediatamente da produção material, além de ser ela mesma condicionada à materialidade econômica, como veremos logo mais, ainda neste item.

E que não se esqueça que as superestruturas possuem uma existência própria, relativamente autônoma. O direito, enquanto forma, não existe apenas nas mentes dos indivíduos e na atividade intelectual dos juristas. Pasukanis realça que ele possui "uma história real, paralela, que tem seu desenvolvimento, não como um sistema conceitual, mas como um sistema de relações ${ }^{10 "}$. O tribunal e o processo são, na perspectiva deste autor, a realização completa da forma jurídica, demonstrando que os fenômenos jurídicos são objetivos, tanto quanto os econômicos.

Prossigamos. É no interior do complexo chamado modo de produção que ocorre a interação entre a estrutura e as superestruturas; resta saber como ela se dá. Uma vez afastada a equivocada compreensão de que as superestruturas seriam projeções ou ilusões, é hora de dar combate às leituras do marxismo que, declarando-se "modernas" ou "antidogmáticas", negam a existência de determinações econômicas. Para alguns revisionistas, falar em termos de estrutura e superestrutura seria um dogmatismo que engessaria a análise de fenômenos como o direito. O PC do B, típica organização reformista, apresenta por um de seus portavozes o entendimento de que o direito é um fenômeno social de composição múltipla, "não só sob a forma jurídica, mas sim sob a dimensão das relações sociais, como forma de produção e reprodução dos seres humanos em determinada sociedade $^{11 " .}$. Tal totalização abstrata é tão vazia que torna a realidade ininteligível, não nos dizendo absolutamente nada. Uma "composição múltipla" atirada ao vazio, infensa a critérios de determinação, conduz a esta conclusão:

Para garantir a sobrevivência do ser humano e a execução de seus objetivos essenciais, é necessária a instauração de uma ordem que direcione e organize as relações sociais. Como ficou comprovado toda sociedade precisa de normas - por mais rudimentares que sejam -, não importa o grau de desenvolvimento ou o conteúdo destas relações. Para determinada sociedade - não importa se capitalista, socialista ou comunista - continuar existindo e alcançar seus objetivos, é necessário que os meios

\footnotetext{
${ }^{10}$ PASUKANIS, Op. Cit., 1989, p. 8.

11 SILVA, Leandro Alves. Direito e marxismo: um encontro necessário. Disponível em: < http://www.fmauriciograbois.org.br/portal/impriminot.php?id sessao $=8 \& i d$ noticia $=2280>$. Acesso em 23 de abr. 2011.
} 
de adaptação social, notadamente o direito, garantam a continuidade dessa sociedade.

O direito é o instrumento que cumpre a função de dar estruturas a estas relações sociais, dando-Ihes forma e condições de consolidar os objetivos de determinada sociedade. Ele funciona como estruturador e mediador das relações sociais, econômicas e políticas; portanto, relações de poder. $O$ direito serve como amálgama e orientador da sociedade em desenvolvimento ${ }^{12}$.

Como se vê, o direito acaba sendo desfigurado como um conjunto qualquer de normas, bem ao gosto do rude positivismo. Com isto, estaria dada a eternidade do direito (ubi societas, ibi ius), já que nenhuma sociedade se organiza sem normas $^{13}$. Mas a elaboração não para por aí: o autor consegue enxergar no direito um instrumento que dá estrutura às relações sociais (sejam elas quais forem), consolida os "objetivos" da sociedade (sejam eles quais forem) e ainda estrutura, novamente, as relações sociais, econômicas e políticas, além de Ihes servir como um mediador.

Pululam diversas obscuridades desta orientação. Limitar-nos-emos a duas: se o direito cumpre todas aquelas funções, o que resta? Para esta importante corrente reformista, o direito é não só onipotente (estrutura todas as relações), como também onipresente, e em qualquer época das sociedades. Outro ponto obscuro: se o direito serve como "amálgama e orientador da sociedade em desenvolvimento", como um aparo para as relações humanas, como se dá a interação com estas relações? Pela regulação, dirá o autor, imerso na concepção normativista. $E$ quanto às relações políticas, econômicas e sociais? Como interagem entre si? Esta informação nos é omitida, mas é inteiramente presumível. Quando eliminou as categorias "ultrapassadas" de estrutura e superestrutura, nosso teórico aceitou tacitamente que tudo determina tudo (o que é o mesmo que dizer que não há determinações), cabendo ao direito arquitetar este quiproquó. Por conseguinte, os eventos históricos restam entregues ao acaso, como se fossem aleatórios, ou melhor, carentes de

\footnotetext{
${ }^{12}$ SILVA, Op. Cit., 2011.

${ }^{13}$ A crítica de Kashiura Júnior cai como uma luva: "Ignorar o caráter histórico da forma jurídica é a atitude típica das correntes que tomam como a forma do direito a forma do comando externo, da vontade tornada obrigação, da norma (hipótese à qual se atribui conseqüência jurídica) etc. Tratamse todas de formas vagas, alheias à dinâmica real das sociedades, que, independentes do conteúdo, pura e simplesmente permanecem inalteradas ao longo da história. Em verdade, são abstrações tão vazias que podem se reportar à história humana inteira sem exigir descer às minúcias das relações sociais dominantes em cada período, aos detalhes das ordens sociais, à estrutura dos modos de produção" (KASHIURA JÚNIOR, Celso Naoto. Dialética e forma jurídica - considerações acerca do método de Pachukanis. In: NAVES, Márcio Bilharinho (org.). 0 discreto charme do direito burguês: ensaios sobre Pachukanis. Campinas, SP: UNICAMP, Instituto de Filosofia e Ciências Humanas, 2009, p. 57).
} 
causas objetivamente identificáveis. As ciências humanas não têm razão de ser neste esquema, que está longe de ser marxista, embora se autoproclame como tal.

Já basta. Voltaremos ao fundador do materialismo histórico, malgrado o pesar que isto possa causar aos revisionistas. Ao ser interpelado por uma crítica publicada num periódico teuto-americano, que dizia que o condicionamento do processo da vida social, política e intelectual pelo modo de produção da vida material seria verdadeiro no capitalismo, mas não na Idade Média (sob o reinado do catolicismo) e nem em Roma ou Atenas (sob o reinado da política), Marx respondeu:

De início, é estranho que alguém se compraza em pressupor o desconhecimento por outrem desses lugares-comuns sobre a Idade Média e a Antiguidade. O que está claro é que nem a Idade Média podia viver do catolicismo, nem o mundo antigo, da política. Ao contrário, é a maneira como ganhavam a vida que explica por que, numa época, desempenhava o papel principal a política, e, na outra, o catolicismo. De resto, basta um pouco de conhecimento da história da República Romana para saber que sua história secreta é a história da propriedade territorial. Já Dom Quixote pagou pelo erro de presumir que a cavalaria andante era compatível com qualquer estrutura econômica da sociedade ${ }^{14}$.

A resposta tem o mérito de deixar nas entrelinhas que "a determinação econômica pode ser pensada como uma determinação em última instância, e não

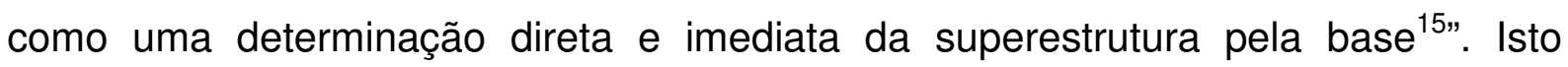
significa que elementos superestruturais como a política e a religião podem ser dominantes numa sociedade, é dizer, podem "desempenhar o papel principal", conforme definir a estrutura econômica. E esta base define a instância dominante ao combinar meios de produção e força de trabalho, originando inúmeras possibilidades de relações de produção e distinguindo as diferentes épocas econômicas da humanidade.

Logo se vê, então, como o marxismo é plenamente capaz de enfrentar diferentes situações com desenvoltura e criatividade, algo bem distante da caricatura

\footnotetext{
${ }^{14}$ MARX, Karl. O capital: crítica da economia política: livro I, vol. I, 26ª . ed.. Tradução de Reginaldo Sant'Anna. Rio de Janeiro: Civilização Brasileira, 2008, p. 104, nota de rodapé. Nossas referências à obra $O$ capital, a partir de agora, observarão um padrão particular: abreviação "C.", seguida pelos números do livro e do volume em algarismos romanos, com os números das páginas citadas em algarismo indo-arábicos ao final. No caso: C., I, I, p. 104, nota de rodapé.

${ }^{15}$ NAVES, Márcio Bilharinho. Marx: Ciência e Revolução. São Paulo: Quartier Latin, 2008, p. 117. Confira-se o também o aporte de Althusser com sua perspectiva de sobredeterminação: "a economia determina, mas em última instância, a longo prazo, diz de bom grado Engels, o curso da História. Mas esse curso 'abre o seu caminho' através do mundo das formas múltiplas da superestrutura, das tradições locais e das circunstâncias internacionais" (ALTHUSSER, Louis. A favor de Marx, 2. ㄹ ed.. Tradução de Dirceu Lindoso. Rio de Janeiro: Zahar, 1979, p. 98).
} 
mecanicista pintada por seus críticos e detratores. Basta utilizar o arsenal teórico com argúcia. A Nicos Poulantzas, notável expoente do marxismo francês, não faltou esta argúcia quando pontuou que "o tipo de unidade que caracteriza um modo de produção é o de um todo complexo com dominância, em última instância, do econômico: dominância em última instância ${ }^{16 ",}$, para a qual reservou o termo de "determinação", dele fazendo um uso bastante acurado. Analogamente, embora com outra terminologia, Étienne Balibar prefere dizer que "a economia é determinante na medida em que determina qual das instâncias da estrutura social ocupa o lugar determinante", sendo que, no modo de produção capitalista, conclui-se que "esse lugar é ocupado pela própria economia ${ }^{17 " . ~}$

Outra contribuição interessante de Balibar foi pensar os modos de produção sem qualquer nódoa de dogmatismo, movendo-se em direção oposta à tradição stalinista, que cristalizou cinco modelos (escravista, feudal, capitalista, socialista, comunista $\left.^{18}\right)$. Esta cartilha positivista, imposta por fraudes, aberrações teóricas e terrorismo de Estado, em nada corresponde ao potencial dinâmico dos conceitos marxistas. Há modos de produção que nunca existiram sob forma independente, (como o "modo de produção mercantil" e o "modo de produção camponês"), os quais não entram na "periodização", e outros cujas condições gerais podemos apenas prever (como o socialismo). No mesmo diapasão, a ideia de uma formação social que combine diferentes modos de produção em concreto só faz enriquecer as potencialidades de explicação do real pelo marxismo.

Retornando ao foco do presente item, parece-nos que o conceito de modo de produção e suas categorias passaram por bom exame. Nosso trajeto até aqui forneceu o material necessário para o próximo passo, que é a análise específica da superestrutura jurídica.

\footnotetext{
${ }^{16}$ POULANTZAS, Nicos. Poder político e classes sociais. Tradução de Francisco Silva. São Paulo: Martins Fontes, 1977, p. 13. E prossegue o autor na página seguinte: "O que, portanto, distingue um modo de produção de outro (e que por conseguinte especifica um modo de produção) é esta forma particular de articulação que seus níveis apresentam entre si: é o que doravante designaremos pelo termo de matriz de um modo de produção".

${ }^{17}$ BALIBAR, Étienne. Sobre os conceitos fundamentais do materialismo histórico. In: ALTHUSSER, Louis (org.). Ler O capital: vol. II. Tradução de Nathanael C. Caixeiro. Rio de Janeiro: Zahar, 1980, pp. $179-180$.

${ }^{18} \mathrm{O}$ stalinismo deliberadamente silenciou sobre o modo de produção asiático de que Marx chegou a falar por conta de sua inconveniente semelhança com a estrutura social da URSS depois do triunfo da contrarrevolução burocrática. E não satisfeito, Stalin ainda proclamou, em 1936, que o socialismo havia sido efetivamente instaurado naquele país. Esta questão será examinada no último capítulo de nosso estudo.
} 


\title{
2.2. As categorias da forma jurídica
}

Considerando que o direito é uma instância ou um nível de um modo de produção, faz-se mister pensá-lo como uma peça neste conjunto, mas sem lhe tolher a individualidade. $\mathrm{O}$ modo de produção determina o lugar que o direito ocupa na sociedade, o que não exclui, como vimos de passagem com Pasukanis, a história real e paralela das categorias que compõem a forma jurídica. E é por elas que a crítica deve começar.

Tratar da forma jurídica implica esmiuçar conceitos que são "utilizáveis em qualquer domínio do direito em decorrência de sua natureza abstrata", de sorte que a sua "significação lógica e sistemática permanece a mesma, independentemente do conteúdo concreto ao qual sejam aplicados ${ }^{19}$ ". Esses conceitos foram todos organizados pela dogmática jurídica (ou técnica jurídica ${ }^{20}$, se quisermos), sem que isto afaste seu valor científico. Pasukanis explica:

\begin{abstract}
O fato, portanto, de que a dogmática jurídica é uma disciplina prática, e em certo sentido técnica, não nos permite concluir que os conceitos dogmáticos não possam evoluir para o corpo de uma disciplina teórica correspondente. Podemos concordar com Karner (isto é, Renner), quando afirma que a ciência do direito começa onde termina a dogmática jurídica. Mas daí não se conclui que a ciência do direito deva simplesmente lançar fora as abstrações fundamentais que exprimem a essência teóriça da forma jurídica. A própria economia política começou efetivamente o seu desenvolvimento pelas questões práticas, extraídas sobretudo da esfera da circulação do dinheiro ${ }^{21}$.
\end{abstract}

Percebe-se claramente a perspectiva dialética de Pasukanis, com todo o seu rigor. O jurista soviético nos conduz à chamada crítica imanente, procedimento pelo qual os conceitos e premissas de um sistema filosófico são estimulados e desenvolvidos na sua lógica até que esbarrem nos seus limites intrínsecos, até que

\footnotetext{
${ }^{19}$ PASUKANIS, Op. Cit., 1989, p. 11.

${ }^{20}$ Alysson Mascaro comenta com perspicácia a insuficiência teórica do positivismo, que confunde técnica e ciência: "É preciso reconhecer que a técnica que permeia as normas jurídicas é grande parte desses objetos, mas não tudo. Por isso uma ciência do direito ou é um conhecimento amplo, dialético, envolvendo várias ciências e analisada dentro da história social, ou então ela será um conhecimento empobrecido, meramente técnico e restrito" (MASCARO, Alysson Leandro. Introdução ao estudo do Direito. São Paulo: Quartier Latin, 2007, pp. 52-53).

${ }^{21}$ PASUKANIS, Op. Cit., 1989, p. 13. Analogamente, Bernard Edelman indica que "les catégories juridiques disent sans dire la realité des rapports dont elles sont l'expression". Em língua vernácula: "as categorias jurídicas dizem sem dizer a realidade das relações de que são a expressão" (EDELMAN, Bernard. Le droit saisi par la photographie: élements pour une théorie marxiste du droit. Paris: Flammarion, 2001, p. 13). As citações de textos em idiomas estrangeiros serão traduzidas livremente por nós.
} 
a contradição neles embutida revele uma essência oposta à aparência. Neste sentido, a crítica marxista começa no campo do adversário, abstendo-se de rechaçar arbitrariamente seus paradigmas, como se fossem mero lixo ideológico. Com o direito, não há que ser diferente.

As principais categorias da forma jurídica, para Pasukanis, são o sujeito de direito e a relação jurídica. A primeira é a base do fenômeno jurídico, e na medida em que "o sujeito é o átomo da teoria jurídica, seu elemento mais simples, indecomponível ${ }^{22 ",}$, assim como a mercadoria é o elemento mais simples da sociedade capitalista ${ }^{23}$.

Começar pela categoria do sujeito de direito não é nada casual para Pasukanis, que buscou em Marx uma imprescindível indicação metodológica:

\begin{abstract}
A população é uma abstração se deixo de lado as classes que a compõem. Essas classes são, por sua vez, uma palavra sem sentido se ignoro os elementos sobre os quais repousam, por exemplo: o trabalho assalariado, o capital etc. Esses supõem a troca, a divisão do trabalho, os preços etc. $\mathrm{O}$ capital, por exemplo, não é nada sem trabalho assalariado, sem valor, dinheiro, preços etc. Se começasse, portanto, pela população, elaboraria uma representação caótica do todo e, por meio de uma determinação mais estrita, chegaria analiticamente, cada vez mais, a conceitos mais simples; do concreto representado chegaria a abstrações cada vez mais tênues, até alcançar as determinações mais simples. Chegado a esse ponto, teria que voltar a fazer a viagem de modo inverso, até dar de novo com a população, mas dessa vez não como uma representação caótica de um todo, porém como uma rica totalidade de determinações e relações diversas. O primeiro método constitui o caminho que foi historicamente seguido pela nascente Economia Política. (...) $\bigcirc$ último método é manifestamente o método cientificamente extato. O concreto é concreto, porque é a síntese de muitas determinações, isto é, unidade do diverso. Por isso, o concreto aparece no pensamento como o processo da síntese, como resultado, não como ponto de partida, embora seja o verdadeiro ponto de partida e, portanto, o ponto de partida também da intuição e da representação. No primeiro método, a representação plena volatiza-se na determinação abstrata; no segundo, as determinações abstratas conduzem à reprodução do concreto por meio do pensamento ${ }^{24}$.
\end{abstract}

Tem aí, nitidamente, a razão de ser da escolha de Pasukanis em partir do sujeito de direito e não da ordem jurídica. Na sociedade burguesa, onde o direito

\footnotetext{
${ }^{22}$ PASUKANIS, Op. Cit., 1989, p. 81.

23 "A riqueza das sociedades onde rege a produção capitalista configura-se em 'imensa acumulação de mercadorias', e a mercadoria, isoladamente considerada, é a forma mais elementar dessa riqueza. Por isso, nossa investigação começa com a análise da mercadoria" (C., I, I, p. 57).

${ }^{24}$ MARX, Karl. Contribuição à crítica da economia política, Op. Cit., 2008, pp. 256-257. Este movimento do abstrato ao concreto é peculiar à dialética de Marx, e sua ausência em Hegel fortaleceu o tom idealista de suas conjecturas. Acabou por lhe conduzir à ilusão de conceber o real como resultado do pensamento, e o pensamento como uma potência autodeterminada.
} 
encontrou seu maior desenvolvimento, o sujeito de direito apresenta-se como a abstração mais elementar da forma jurídica (o que revela sua especificidade e sua historicidade). Nesta abstração, encontramos o correto ponto de partida em direção à concretude (a ordem jurídica). Importa lembrar que, dialeticamente, "o abstrato é tomado para conduzir ao seu concreto: o processo de superação do abstrato é processo de reprodução pelo pensamento do concreto ${ }^{25 " \text {. }}$

É na produção material da vida que está a chave para a explicação dos fenômenos sociais. Nesta perspectiva, a origem do sujeito jurídico situa-se no momento em que suas características foram inauguradas na prática social, cabendo entender por sujeito um núcleo de direitos e obrigações, uma individualidade que se encontra no mesmo plano que as outras, sendo livre para estabelecer relações e realizar interesses. Ora, é apenas num universo em que a vida é fabricada atomisticamente que estão colocados os requisitos objetivos para que o sujeito de direito tenha lugar na história. Este universo é aquele em que os indivíduos estão inseridos numa certa divisão do trabalho que os leva a trocar os bens que produziram de modo insular. A mercadoria, assim, converte-se na forma social necessária que os produtos assumem na divisão do trabalho instaurada pelo capitalismo.

Marx afirmou que a troca mercantil exige que os responsáveis pelas mercadorias se comportem, reciprocamente, como pessoas cuja vontade reside nessas coisas, "de modo que um só se aposse da mercadoria do outro, alienando a sua, mediante o consentimento do outro, através, portanto, de um ato voluntário comum $^{26 " . ~ E ́ ~ e x a t a m e n t e ~ n e s t e ~ a t o ~ v o l u n t a ́ r i o ~ d e ~ t r o c a ~ q u e ~ a s ~ m e r c a d o r i a s ~ s a ̃ o ~}$ permutadas, configurando-se uma relação jurídica entre os seus portadores, cujo conteúdo é dado pela relação econômica. Para o direito, o que importa é a forma do ato.

Tem-se então que o homem é colocado como sujeito em oposição às coisas que porta, e que esta categoria é abstraída do ato de troca. No mercado, os agentes detêm a liberdade formal de autodeterminação para trocar suas mercadorias e são considerados iguais, pois um não pode constranger o outro pela força na troca de valores equivalentes. Finalmente, reconhecem-se uns aos outros como proprietários

\footnotetext{
${ }^{25}$ KASHIURA JÚNIOR, Dialética e forma jurídica - considerações acerca do método de Pachukanis. Op. Cit., 2009, p. 65.

${ }^{26}$ C., I, I, p. 109.
} 
dos bens que oferecem, requisito prévio para qualquer troca. Nesses termos, o sujeito de direito é um "proprietário abstrato e transposto para as nuvens", é o desdobramento forçoso de uma sociedade que, ao se basear na produção de mercadorias, é presidida pela lei do valor, de tal sorte que "cada homem torna-se um homem em geral, cada trabalho torna-se trabalho social útil em geral, cada indivíduo torna-se um sujeito de direito abstrato ${ }^{27 ", .}$

No capitalismo, a produção de mercadorias alcança o seu apogeu. Havia mercado em outras formações sociais, há de se assumir. Contudo, é somente na sociedade burguesa que a produção de bens para a circulação mercantil deixa de ser marginal e passa a ser central, tornando-se o eixo de toda a reprodução da sociedade. A consequência disto não é nada desprezível para o estudo do direito: a forma jurídica só atingiu sua maturidade, isto é, a plenitude de seus patamares, sob o capitalismo. Eis a constatação de Pasukanis:

\footnotetext{
É apenas na economia mercantil que nasce a forma jurídica abstrata, em outras palavras, que a capacidade geral de possuir direitos se separa das pretensões jurídicas concretas. Só a contínua transferência de direitos que ocorre no mercado cria a idéia de um portador imutável destes direitos. No mercado, aquele que obriga, obriga-se simultaneamente. A todo momento ele passa da condição de credor à de obrigado. Assim foi criada a possibilidade de abstraírem-se as diferenças concretas entre os sujeitos de direito e englobá-los sob um único conceito genético ${ }^{28}$.
}

Quando a força de trabalho é tornada uma mercadoria, o fluxo mercantil deixa de se restringir aos círculos restritos e passa a envolver todo o tecido social, em contraste com outros modelos de sociedade. No escravismo e no feudalismo, por exemplo, o direito existe apenas em estado embrionário, confundindo-se com outras esferas sociais (como os costumes e a religião ${ }^{29}$ ). Seus elementos mostravam-se apenas como formas antediluvianas do direito, analogamente às formas antediluvianas do capital na Idade Média (o capital usurário e o capital comercial). Ao olharmos para a sociedade feudal, está claro que nela o direito não era uma esfera autônoma. Ele se fundia com os cânones da Igreja e com os costumes dos

\footnotetext{
${ }^{27}$ PASUKANIS, Op. Cit., 1989, p. 94.

${ }^{28}$ PASUKANIS, Op. Cit., 1989, pp. 90-91.

29 "O romano que pronunciava palavras sagradas para selar um pacto profano, o vassalo que se ligava por laços de dependência pessoal ao suserano, o sistema de provas conhecido como ordália e o direito oriundo das monarquias absolutas, para ficar apenas com os exemplos mais patentes, atestam a indiferenciação da forma jurídica em relação a outros domínios da vida social" (KASHIURA JÚNIOR, Dialética e forma jurídica - considerações acerca do método de Pachukanis. Op. Cit., 2009, p. 61).
} 
comerciantes. A igualdade entre as pessoas, própria do sujeito de direito, era restrita a esferas diminutas, de sorte que cada estamento possuía seus privilégios. Faltava a generalização das trocas para que o direito se emancipasse das outras instâncias e se enraizasse nas mais diversas atividades humanas, muito além daquelas diretamente ligadas à circulação mercantil.

O outro conceito básico do direito é a relação jurídica, a qual, na teoria pasukaniana, "é a célula central do tecido jurídico", sendo "somente nela que o direito realiza o seu movimento real ${ }^{30 " . ~}$. Neste ponto, o contraste com as teorias normativistas não poderia ser mais evidente: a norma deixa de ser o cerne, cedendo lugar ao dinamismo real das relações que os sujeitos travam entre si. Assenta-se uma "posição teórica antinormativista que recusa a prevalência da norma sobre a relação, isto é, que recusa a premissa de que é a norma que gera a relação jurídica ${ }^{31 " .}$

A norma, na verdade, é "tanto um elemento da moral, da estética, da técnica, quanto, ao mesmo título, um elemento do direito ${ }^{32, " . ~ S o ́ ~ f a z ~ j u s ~ a o ~ t i ́ t u l o ~ d e ~ n o r m a ~}$ jurídica quando se reporta a pessoas munidas de direitos. Estes direitos, por sua vez, não decorrem das normas, e sim das relações sociais. Eis porque o direito subjetivo é o fato primário, assentando-se sobre interesses materiais que independem de regulamentação externa. A ordem jurídica, concebida como uma cadeia de sujeitos vinculados entre si por relações recíprocas, nas quais os direitos se realizam, efetivamente corresponde à estrutura econômica de uma comunidade que se organiza pelas trocas.

No esquema pasukaniano, a norma jurídica é extraída de relações preexistentes, ou então representa, quando promulgada como lei estatal, "um sintoma que nos permite prever, com uma certa verossimilhança, o futuro nascimento de relações correspondentes ${ }^{33}$ ". Afinal, o que importa não é o conteúdo normativo em si, mas a sua vivência de fato no mundo real. A decadência da ciência burguesa do direito, como constata Pasukanis acerca do positivismo normativista encabeçado por Hans Kelsen, revela-se no ato de deliberadamente dar as costas à realidade, escolhendo estudar aquilo que "deveria ser" ao invés daquilo que "é".

\footnotetext{
${ }^{30}$ PASUKANIS, Op. Cit., 1989, p. 56.

${ }^{31}$ NAVES, Márcio Bilharinho. Marxismo e direito: um estudo sobre Pachukanis. São Paulo: Boitempo, 2008, p. 64.

${ }_{32}$ PASUKANIS, Op. Cit., 1989, p. 72.

${ }^{33}$ PASUKANIS, Op. Cit., 1989, p. 57.
} 
Acrescente-se ainda que uma norma emanada pelo poder político pode dispor sobre o conteúdo das relações jurídicas de diversas maneiras. Só não lhe é dado inibir ou subverter a forma jurídica, que se origina das relações de produção sem a necessidade do Estado como um elo intermediário. O direito escapa ao Estado, e o Estado não produz direito propriamente, podendo apenas criar condições favoráveis para tanto. A troca mercantil sempre se dá pela via contratual, queira a autoridade instituída ou não. Outrossim, estando generalizadas as trocas, toda vez que os indivíduos compuserem seus interesses nivelados pela igualdade formal (ou por gradações desta), estarão se comportando como sujeitos de direito entrelaçados por relações jurídicas.

Qualquer relação jurídica espelha-se, em maior ou menor medida, na figura do contrato, o "berço" do direito. Mesmo as ramificações do direito público carregam com elas a marca de nascença do contrato, ou, melhor dizendo, esta estrutura em estado vestigial. A forma jurídica é o reino da propriedade, da liberdade e da igualdade encarnado nos sujeitos de direito em contato uns com os outros nas suas relações jurídicas, e é por isso que ela se efetiva com mais conforto e plenitude na seara do direito privado. O direito público, portanto, "só pode existir enquanto refletir a forma jurídica privada na esfera da organização política, ou então deixa de ser um direito $34 "$.

Mais ainda: a liberdade e a igualdade jurídicas só encontram sua razão de ser em torno da propriedade privada, o sustentáculo da santíssima trindade que compõe o sujeito de direito. Como diz Edelman, "la mise en mouvement de la propriété privée crée bien une liberté et une égalité, mais cette liberté et cette égalité sont celles-là mêmes de la propriété privée $e^{35 " .}$.

Parece pertinente observar que o direito atua, ao fim e ao cabo, como um nivelador. A forma jurídica nada mais é do que "uma forma de relação voluntária

\footnotetext{
${ }^{34}$ PASUKANIS, Op. Cit., 1989, p. 75. Segundo a teoria deste autor, a forma jurídica é extraída da relação mercantil e repassada para as outras relações sociais, o que realça sua natureza privatista. A explicação de Silvia Alapanian é elucidativa: "Todo o direito está baseado na relação que estabelecem entre si os proprietários de mercadorias, de maneira que o direito é essencialmente privado, e as demais formas do direito (criminal, constitucional, etc.) estão baseadas na lógica das relações mercantis e, portanto, privadas, ou, pelo menos, contaminadas por elas (ALAPANIAN, Silvia. A crítica marxista do direito: um olhar sobre as posições de Evgeni Pachukanis. In: NAVES, Márcio Bilharinho (org.). $O$ discreto charme do direito burguês: ensaios sobre Pachukanis. Campinas, SP: UNICAMP, Instituto de Filosofia e Ciências Humanas, 2009, p. 40)

35 "A colocação em movimento da propriedade privada cria de fato uma liberdade e uma igualdade, mas esta liberdade e esta igualdade são aquelas mesmas da propriedade privada" (EDELMAN, Op. Cit., 2001, p. 110).
} 
entre sujeitos equivalentes ${ }^{36 " .}$. O formalismo que lhe é inerente abstrai as desigualdades factuais em todas as relações jurídicas, o que se dá em grau mais elevado no contrato de trabalho, cerne do direito do trabalho. No capitalismo, explorador e explorado são colocados numa mesma plataforma. Ambos são sujeitos de direito; ambos são proprietários contratantes, e Marx já identificava a lógica do vínculo entre eles:

\begin{abstract}
A esfera que estamos abandonando, da circulação ou da troca de mercadorias, dentro da qual se operam a compra e a venda da força de trabalho, é realmente um verdadeiro paraíso dos direitos inatos do homem. Só reinam aí liberdade, igualdade, propriedade e Bentham. Liberdade, pois o comprador e o vendedor de uma mercadoria - a força de trabalho, por exemplo - são determinados apenas pela sua vontade livre. Contratam como pessoas livres, juridicamente iguais. $O$ contrato é o resultado final, a expressão jurídica comum de suas vontades. Igualdade, pois estabelecem relações mútuas apenas como possuidores de mercadorias e trocam equivalente por equivalente. Propriedade, pois cada um só dispõe do que é seu. Bentham, pois cada um dos dois só cuida de si mesmo. A única força que os junta e os relaciona é a do proveito próprio, da vantagem individual, dos interesses privados ${ }^{37}$.
\end{abstract}

Neste trecho, fica claro o embuste contido na encantadora fórmula de igualdade do mercado, lastreada na troca simples, sendo que, em verdade, o que se tem é uma relação capitalista. O fato de que o capitalista e o trabalhador se encontram como detentores de mercadorias obscurece a extração do trabalho excedente. A compra da força de trabalho pelo proprietário dos meios de produção faz com que o trabalhador produza para si e para o capitalista mediante uma paga salarial que corresponde apenas ao valor da mercadoria que alienou, nunca ao valor total que efetivamente produziu. A igualdade formal jurídica é o intermediário necessário para que se efetive a desigualdade material de classe e o açambarcamento do labor alheio.

Nada disso se leva em conta sob o prisma do direito, pelo qual se enxerga apenas dois sujeitos livres, iguais e proprietários (ou potencialmente proprietários ${ }^{38}$ )

\footnotetext{
${ }^{36}$ KASHIURA JÚNIOR, Dialética e forma jurídica - considerações acerca do método de Pachukanis. Op. Cit., 2009, p. 61.

${ }^{37}$ C., I, I, p. 206. E logo adiante, na mesma página, Marx aduz que muda a "fisionomia" dos personagens envolvidos na operação mercantil (agora capitalista): "O antigo dono do dinheiro marcha agora à frente, como capitalista; segue-o o proprietário da força de trabalho, como seu trabalhador. $\mathrm{O}$ primeiro, com um ar importante, sorriso velhaco e ávido de negócios; o segundo, tímido, contrafeito, como alguém que vendeu sua própria pele e apenas espera ser esfolado".

38 "A forma jurídica da propriedade não está em contradição com a expropriação de um grande número de cidadãos, pois a condição de ser sujeito de direito é uma condição puramente formal. Ela define todas as pessoas como igualmente 'dignas' de serem proprietárias, não obstante não as torne proprietárias" (PASUKANIS, Op. Cit., 1989, p. 101).
} 
compondo seus interesses particulares. E não se diga que o direito do trabalho considera a desigualdade factual quando atribui, por lei, encargos contratuais diferentes a cada contratante. Enquanto contratantes, capitalista e trabalhador são sujeitos de direito. Em adendo, a coleta da mais-valia, que nada mais é do que o modo burguês de explorar mão-de-obra, permanece encoberta e intocada mesmo no contrato celebrado sob a legislação trabalhista mais rigorosa que se possa imaginar.

Quando se adota o sujeito de direito e a relação jurídica como eixos de estudo do direito, a distinção entre Estado e direito torna-se, enfim, nítida, e o direito internacional assim o demonstra. A forma jurídica está presente na celebração de um tratado entre países (estão aí os sujeitos de direito e a relação jurídica), apesar da ausência de um poder externo. Obviamente, a coerção vertical de um Estado traz mais estabilidade para as relações jurídicas, o que não quer dizer que ela seja um requisito essencial. Seja como for, o papel de uma ordem que cuide para que as relações jurídicas sigam fluindo, mesmo sem lhes originar, não pode ser ignorado.

\subsection{Direito e Estado capitalista}

Há muito que se dizer sobre o Estado, e em particular sobre o Estado capitalista. Tendo em vista os limites em que se circunscrevem esta obra, buscaremos expor apenas o indispensável para dar fechamento ao raciocínio e para preparar as abordagens dos próximos capítulos.

No que tange ao Estado, o marxismo é um verdadeiro divisor de águas. Assim como compreendeu a luta de classes como o motor da história e o conflito capital-trabalho como a relação social específica que molda a modernidade em última instância, viu no Estado a cristalização do domínio de classe. Onde o pensamento acrítico enxerga paz e harmonia, a dialética de Marx denuncia contradições fundamentais. Longe de ser o produto do acordo de indivíduos que se entregam a um contrato social ou o paroxismo da razão, o Estado é fator de subjugação das classes laboriosas e de reiteração dos pilares sociais. A igualdade jurídica chancelada pelo Estado não é mais do que a maneira como a desigualdade espoliativa do capitalismo se apresenta, num vivo contraste entre aparência e essência. 
No interior do espectro marxista, abarcando autores tão diferentes como Bukharin, Gramsci e Althusser, vinga a concepção elementar de que o Estado constitui um conjunto de aparelhos que, orientados para a reposição sistêmica, exercem funções repressivas (exército, polícia, tribunais etc.) e ideológicas (escola, mídia, igreja etc. $)^{39}$. A dominação burguesa se exerceria pela força ou pelo consenso, sendo que o consenso é sempre escudado na força. Ao fim da mansuetude das massas, vem o momento da violência organizada contra as ações dos irresignados. Assim, o Estado compreende as linhas de defesa de uma dada sociedade de classes, quer dizer, do seu modelo de exploração, seja tutelando contratos ou esmagando ameaças à propriedade, seja arregimentando corações e cérebros para a paz social. Sem esta intervenção estatal, o edifício que abriga a extração de sobretrabalho não se sustenta. Não haveria acumulação e reprodução possíveis.

Cumpre postular desde já que a concepção dicotômica (repressão-ideologia) do fenômeno estatal não é capaz de esgotá-lo, como nos previne Nicos Poulantzas. Este teórico enfatiza que leituras baseadas apenas da citada dicotomia reduzem o Estado a uma força que agiria apenas negativamente, proibindo e ocultando ${ }^{40}$. Não se trata de negar, de modo algum, o papel da força e do consenso, mas sim de lançar luz sobre a função econômica direta do Estado enquanto agente indispensável ao processo de reprodução do capital. Seria necessário, assim, falar também em aparelhos econômicos de Estado, se quisermos preservar a nomenclatura althusseriana. As intervenções estatais na economia, cada vez mais indispensáveis, configuram uma conduta positiva na preservação do capitalismo. A ideia de um Estado garante das relações de produção está indubitavelmente correta,

\footnotetext{
${ }^{39}$ Althusser, por exemplo, estabelece uma divisão entre aparelhos repressivos de Estado e aparelhos ideológicos de Estado, sendo que, nos primeiros, predomina o uso da coerção, ao passo que nos segundos predomina a cooptação. $\mathrm{O}$ aparelho jurídico, em particular, seria a um só tempo repressivo e ideológico. Conferir mais em ALTHUSSER, Louis. Aparelhos ideológicos de Estado: nota sobre os aparelhos ideológicos de Estado. Tradução de Walter José Evangelista e Maria Laura Viveiros de Castro. São Paulo: Graal, 2007. A teoria de Edelman é do mesmo tom, inferindo que "le Droit assume cette double fonction de fixer concrètement et 'imaginairement' - et il vaudrait mieux dire que la fixation concrète juridique est en même temps idéologique - l'ensemble des rapports sociaux" (EDELMAN, Op. Cit., 2001, p. 104). Traduzindo: "o direito assume esta dupla função de fixar concreta e imaginariamente - e seria melhor dizer que a fixação concreta jurídica é ao mesmo tempo ideológica - o conjunto das relações sociais".

40 "Em suma, o Estado também age de maneira positiva, cria, transforma, realiza. Não se pode tomar as atuais ações econômicas do Estado, a menos que se faça um jogo de palavras, sob o exaustivo ângulo da repressão e da doutrinação ideológica, ficando claro, contudo, que estes aspectos existem claramente na materialidade das atuais funções do Estado" (POULANTZAS, Nicos. 0 Estado, o poder, o socialismo, 4a. ed.. Tradução de Rita Lima. São Paulo: Paz e Terra, 2000, p. 29).
} 
desde que assumida com uma amplitude que abrigue medidas econômicas cotidianas em favor do capital, algo distante da imagem transmitida por um mero "vigilante" de prontidão.

Das dimensões do Estado que comentamos, aquela que se comunica mais diretamente com a forma jurídica é a repressiva ${ }^{41}$. Se os sujeitos de direito, por serem iguais entre si, não podem coagir seus pares a observarem as regras do jogo (assim como os portadores de mercadorias não podem subjugar uns aos outros no mercado), esta tarefa recai sobre uma autoridade que não se confunde com nenhum indivíduo, e que é capaz de, legitimamente, exercer a coação. Ela deve, monopolizando a violência, mensurar (e não atribuir) os direitos de cada um conforme cada relação jurídica, assegurando a igualdade dos sujeitos inspirada no critério de equivalência da lei do valor.

Ao considerarmos que a exploração das classes dominadas e a reprodução social, no capitalismo, mediatizam-se por uma relação mercantil (compra e venda de força de trabalho no processo de produção), podemos concluir com Joachim Hirsch que numa formação social capitalista é preciso que a exploração e a reprodução das classes "não se efetuem (...) diretamente pela utilização física da violência, mas através da própria reprodução das relações de produção, regida pela lei do valor ${ }^{42 " .}$ Em outras palavras, o açambarcamento do produto excedente opera-se exclusivamente no universo econômico, cabendo ao poder político uma atuação subsidiária. A equivalência entre os guardiões da mercadoria salário e os guardiões da mercadoria força de trabalho exige um tipo de Estado que observe a igualdade entre as partes, o que o impede de se associar expressamente a uma delas. Consequentemente, há uma separação do aparelho de coerção física em face da classe dominante, a qual se coloca na relação com a classe dominada como um conjunto de contratantes dispostos a trocar valores equivalentes com os trabalhadores que contratam. Os conflitos entre as partes devem ser submetidos à

\footnotetext{
${ }^{41}$ Dimensão esta que é ideologicamente envolvida pela "concepção jurídica de mundo", cumprindo um papel de secularização da visão teológica: "O dogma e o direito divino eram substituídos pelo direito humano, e a Igreja, pelo estado. As relações econômicas e sociais, anteriormente representadas como criações do dogma e da Igreja, porque esta as sancionava, agora se representam fundadas no direito e criadas pelo estado" (ENGELS, Friedrich; KAUTSKY, Karl. 0 socialismo jurídico, 2. a ed.. Tradução de Lívia Cotrim e Márcio Bilharinho Naves. São Paulo: Ensaio, 1995, pp. 24-25).

${ }^{42} \mathrm{HIRSCH}$, Joachim. Observações teóricas sobre o Estado burguês e sua crise. In: POULANTZAS, Nicos (org.). Estado em crise. Tradução de Maria Laura Viveiros de Castro. Rio de Janeiro: Graal, 1977, p. 88.
} 
apreciação de uma autoridade desinteressada, um aparato que, nestas circunstâncias, assume a feição de um ente público, que contempla a comunidade como um oceano de indivíduos que se nivelam apenas sob as lentes jurídicas. Está posta, enfim, a compleição do Estado propriamente capitalista, o fecho do esquema jurídico na maturidade das trocas mercantis.

Uma notável particularidade desse Estado capitalista, há de se observar, é a sua separação formal das classes sociais, em chamativa oposição aos Estados feudal e escravista. Joachim Hirsch intervém no seguinte sentido:

A separação formal entre o Estado e as classes sociais engloba um modo
específico de institucionalização das relações de classe. O que faz com que
as classes economicamente dominantes e as governantes - isto é, as
classes proprietárias e aquelas que dirigem os aparelhos de Estado - não
sejam idênticas ${ }^{43}$.

A dominação política é efetivada por agentes diferentes daqueles que efetivam a dominação econômica, o que joga mais água no moinho da ideologia burguesa e se materializa no perfil institucional do Estado burguês, baseado numa pretensa neutralidade que, em definitivo, reflete a configuração social de relações de classe mediatizadas pela igualdade jurídica.

Salta aos olhos, pelo que expusemos até aqui, a contradição entre aquilo que o Estado é (garante das relações de produção) e aquilo que o Estado sugere sobre si mesmo, e sem falsa modéstia (ente público, promotor do bem comum). Encarando a questão, Ruy Fausto indica que o Estado, em Marx, e no que diz respeito a sua dimensão mais relevante para a forma jurídica, é concebível em dois momentos: o da aparência (guardião da identidade dos contratantes) e o da essência (violência concentrada, uso da força de conservação). A utilidade deste enfoque, para o direito, está em demonstrar que a violência está no cerne do Estado, corresponde ao que ele é de fato. A força bruta que emprega é a força que a burguesia está impedida de empregar diretamente, e que é imprescindível para a manutenção do modo de produção capitalista. Trata-se da violência que cimenta os tijolos de um mundo de exploração, de um universo em que uma camada inteira da população é agredida economicamente, usurpada na riqueza que fabrica e no seu tempo de vida. Logo, "a violência do Estado (...) 'reflete' (...) a violência no interior da sociedade civil, isto é, a

\footnotetext{
${ }^{43} \mathrm{HIRSCH}$, Joachim. Teoria materialista do Estado: processos de transformação do sistema capitalista de Estado. Tradução de Luciano Cavini Martorano. Rio de Janeiro: Revan, 2010, p. 55.
} 
violência do capital $^{44 ”}$. No Estado, a violência da sociedade civil se manifesta, ainda que de modo distorcido, como se decorresse de uma entidade descomprometida com o conflito de classe. Direito e Estado caminham de mãos dadas para, como dizia Trotsky na epígrafe com que abrimos o capítulo, recobrir com "um verniz de boas maneiras" a exploração do homem pelo homem.

A seguir, voltaremos nossos olhares para os chamados direitos humanos de primeira dimensão. Sustentaremos que, em que pesem seu caráter progressista e os condimentos históricos oriundos das lutas dos trabalhadores, os direitos políticos e civis devem-se primordialmente à singularidade do uso da força pelo Estado capitalista no interior das relações sociais que tutela, reportando-se ao regime burguês de dominação.

\footnotetext{
${ }^{44}$ FAUSTO, Ruy. Marx: Lógica e Política: Investigações para uma reconstituição do sentido da dialética: tomo II. São Paulo: Brasiliense, 1987, p. 302. Conceber a violência do Estado como violência da comunidade, ou melhor, da exploração de uma parte da comunidade sobre a outra, é condizente com a interpretação poulantziana acerca do poder: "O conceito de poder não pode assim ser aplicado a um nível de estrutura: quando se fala, por exemplo, de poder de Estado, não se pode indicar com isso o modo de articulação e de intervenção do Estado nos outros níveis da estrutura, mas sim o poder de uma classe determinada, a cujos interesses o Estado corresponde, sobre outras classes sociais" (POULANTZAS, Op. Cit., 1977, pp. 95-96). Para Poulantzas, as relações de classe são relações de poder e as relações de poder são relações de classe.
} 


\title{
3. O MODO DE PRODUÇÃO CAPITALISTA E OS DIREITOS HUMANOS DE PRIMEIRA DIMENSÃO
}

\begin{abstract}
Antes de tudo, constatemos o fato de que os chamados direitos do homem, os droits de l'homme, diferentemente dos droits du citoyen, não são outra coisa senão os direitos do membro da sociedade civil (...), i.e., do homem egoísta, do homem separado do homem e da comunidade ${ }^{45}$.
\end{abstract}

Karl Marx

A ligação entre o modo de produção capitalista e os direitos humanos de primeira dimensão, tal como tencionamos demonstrar, deverá ser exposta em três momentos. Inicialmente, dar-se-á ênfase aos marcos históricos dos direitos civis e políticos, passando-se pela principal polêmica que envolve o marxismo nesta temática: seu atrevimento ao submeter à crítica aquilo que seria incriticável: os direitos civis e políticos, projetados como os fundamentos da civilização e da democracia. Demonstraremos seu caráter de classe e a falácia de sua universalidade. Logo adiante, e inevitavelmente, a democracia liberal será examinada e criticada nos seus fundamentos, conforme as indicações da teoria marxista do Estado. Ao final do capítulo, comentaremos as tendências desta democracia nos instantes em que a luta de classes se agiganta, em que suas tensões forçam o liberalismo a degenerar no seu contrário, mesmo que sob um véu liberal.

Antes, entretanto, convém esboçar uma linha de desenvolvimento histórico que reflita o contexto e as bases materiais da chamada primeira dimensão dos direitos humanos. Capitalismo e direitos humanos caminham de mãos dadas na história, fato que se verifica já no nascimento da ordem capitalista.

\subsection{A aurora do capitalismo}

A dinâmica econômica capitalista caracteriza-se, historicamente, pela transformação do dinheiro em capital, pela extração do excedente do trabalho em favor do capital e pela obtenção de mais capital com o investimento do excedente extraído. Este é o movimento em que se perfaz a acumulação de capital. No

\footnotetext{
${ }^{45}$ MARX, Karl. Para a questão judaica. Tradução de José Barata-Moura. São Paulo: Expressão Popular, 2009, p. 63.
} 
entanto, tal movimento só é possível num cenário favorável, cuja constituição, do ponto de vista histórico e mesmo lógico, antecede o capitalismo.

Capital é valor que se expande no processo capitalista de produção, em que se verifica a compra e venda da mercadoria força de trabalho. Esta mercadoria diferencia-se das demais por ser a única capaz de criar valor. Ao adquirir, pelo contrato de trabalho, o direito de se apropriar do que o trabalhador produz em sua jornada, o capitalista despende apenas o necessário para repor a força de trabalho (e nisto consiste o salário). O valor produzido que excede esta reposição configura um mais valor, um excedente, o qual se denomina mais-valia. Eis a fonte primária do lucro capitalista, destacando que, embora surja na produção, esta mais-valia só se realiza na esfera da circulação, com o "salto mortal da mercadoria".

Temos, assim, que na base desta relação social chamada capital, ou deste processo a que se chama capital, localiza-se a compra e venda da força de trabalho. Tal operação mercantil, invariavelmente, exige a concentração de capital monetário nas mãos de uma classe, de um lado, e a despossessão de bens de outra classe, de outro. Em outras palavras, para que alguém compareça ao mercado para comprar força de trabalho e que alguém compareça para vendê-la, faz-se indispensável um contexto em que um expressivo contingente populacional se veja obrigado a trabalhar (sob pena de inanição) para quem detenha o dinheiro para a paga salarial e os meios de produção para o processo produtivo. E é desta maneira que dinheiro e meios de produção assumem a forma social de capital.

Coloca-se aí a questão de como uns se consagraram à posição de possuidores enquanto outros foram condenados, à maneira de Adão, no mito bíblico, a ter de manter a própria existência (e a da burguesia, no caso) com o suor do próprio rosto. E esta referência bíblica, feita pelo próprio Marx, não é casual. Para que as principais classes do capitalismo tenham se estruturado, pressupõe-se uma acumulação de riquezas prévia para uma minoria e uma despossessão prévia para a maioria. Pressupõem-se, portanto, processos anteriores ao modo capitalista de produção, que dele não decorrem, e daí se falar numa acumulação primitiva, que "desempenha na economia política um papel análogo ao do pecado original na teologia ${ }^{46 "}$.

\footnotetext{
${ }^{46}$ C., I, II, p. 827. E prossegue, ainda nesta página: "Adão mordeu a maçã e, por isso, o pecado contaminou a humanidade inteira. Pretende-se explicar a origem da acumulação por meio de uma história ocorrida em passado distante. Havia outrora, em tempos muito remotos, duas espécies de
} 
Estudar a formação histórica do capitalismo, portanto, exige que se aborde o surgimento dos detentores do capital (burguesia) e dos detentores de força de trabalho (proletariado). E mais do que explicar o surgimento de cada classe, cabe analisar o processo de edificação da estrutura especificamente capitalista, ou seja, o movimento que culmina numa específica relação entre o estrato que produz e 0 estrato que se apropria do excedente produzido ${ }^{47}$.

A burguesia desponta, nos seus começos, como mais uma camada do mundo feudal, embora não pertença originalmente a este universo. Sua origem está na generalização do comércio na Europa medieval, sem a qual esta classe teria continuado na marginalidade econômica e política, ou seja, seguiria ofuscada pela tripartição estamental do feudalismo. Esta expansão comercial que comentamos, por sua vez, deve-se ao crescimento demográfico acentuado a partir do século $X$ e às Cruzadas. Foram estes eventos que favoreceram a ascensão dos mercados e de seus agentes. No norte (mar do norte e mar Báltico), surgiu uma rota comercial nunca antes verificada, que desembocou nas grandes feiras que se constituíram na Inglaterra, França, Bélgica, Alemanha e Itália. Nestas feiras, negociavam-se por atacado imensas quantidades de mercadoria, e dos mais variados pontos do mundo conhecido.

A urbanização caminhou pari passu com o processo de expansão comercial, sendo por ela fomentada. Foi nas cidades, onde os mercadores eram muito influentes, que se originou o anseio por liberdade comercial, isto é, liberdade para mercadejar sem as restrições feudais, para estabelecer tribunais da classe comerciante e para fixar impostos à sua maneira. Alguns direitos (privilégios) feudais foram comprados de senhores feudais para que a cidade caminhasse para a independência. E quando esta independência não foi possível pela via pacífica, ela foi obtida à força. Perceba-se que, em alguns casos, o poder desta burguesia

gente: uma elite laboriosa, inteligente e sobretudo econômica, e uma população constituída de vadios, trapalhões que gastavam mais do que tinham. A lenda teológica conta-nos que o homem foi condenado a comer o pão com o suor de seu rosto. Mas a lenda econômica explica-nos o motivo por que existem pessoas que escapam a esse mandamento divino. Aconteceu que a elite foi acumulando riquezas, e a população vadia ficou finalmente sem ter outra coisa para vender além da própria pele. Temos aí o pecado original da economia. Por causa dele, a grande massa é pobre e, apesar de se esfalfar, só tem para vender a força de trabalho, enquanto cresce continuamente a riqueza de poucos, embora tenham esses poucos parado de trabalhar há muito tempo".

${ }^{47}$ Armando Boito Jr. frisa que "é a formação da estrutura de um modo de produção, e não a gênese de cada um de seus elementos, que configura o processo de transição para esse modo de produção" (BOITO JR., Armando. Os problemas da análise poulantziana de Estado feudal. Crítica Marxista, São Paulo, n. 7, pp. 67-88, 1998, p. 83). 
comercial ascendente ultrapassou em muito o espaço das cidades. A Liga Hanseática da Alemanha, que possuía postos e armazéns fortificados e espalhados da Holanda à Rússia, praticamente monopolizava o comércio do norte da Europa com o resto do mundo. Tinha a força de um Estado em si: estabelecia tratados comerciais, protegia sua frota mercante com navios de guerra, combatia piratas e tinha assembleias de governo que elaboravam suas próprias leis. Mais conhecido ainda é o poderio das cidades italianas que controlavam o circuito mercantil no Mediterrâneo.

E não foram apenas os comerciantes que encontraram na associação um meio de proteger seus interesses. Os artesãos criaram suas corporações de ofício, onde o espírito capitalista estava de todo ausente. Inicialmente, as corporações atinham-se ao preceito católico de "preço justo", de sorte que o lucro excessivo levava ao pelourinho. Predominava a condenação moral à usura e à riqueza ostensiva. Com o desenvolvimento do mercado e do capital comercial, entretanto, as concepções morais tipicamente medievais cederam lugar à aceitação dos preços de mercado. A noção do justo preço se enquadrava apenas na economia local e estável, organizada em torno da lógica do valor de uso dos bens, tal como se dava no feudalismo.

Algumas corporações de ofício se tornaram ricas e poderosas, chegando, inclusive, a subjugar as demais. À medida que crescia a procura pelas cidades, os mestres envidavam esforços para preservar seus privilégios, criando obstáculos para a ascensão profissional. Os artesãos eram mal remunerados e enfrentavam longas jornadas de trabalho. Pessoas que não conseguiam se associar acabavam condenadas à mendicância. Esta situação deflagrou uma série de revoltas na Europa ocidental, uma luta entre privilegiados e desprivilegiados. Depois desse período de desordem, as corporações principiaram a enfraquecer e o poder das cidades livres entrou em declínio. Passaram a ser controladas de fora, por um nobre, um príncipe ou um rei mais forte do que os que até então existentes, num processo incipiente de unificação de regiões em torno de um Estado nacional.

Essas transformações foram da mais alta relevância para a época. Nas palavras de Castel:

A sociedade medieval passou, assim, de uma civilização essencialmente agrária, estreitamente dominada pelas grandes propriedades eclesiásticas e por um poder senhorial e guerreiro, a uma bipolaridade entre comunidades 
rurais mais diversificadas e comunidades urbanas mais prósperas e mais independentes. A cidade, sem dúvida, permanece quantitativamente marginal, mas é a partir dela que se desenvolvem o artesanato, as trocas comerciais, a economia monetária, as técnicas bancárias do capitalismo comercial $^{48}$.

Era cristalina a decrepitude do feudalismo, sendo ainda catalisada pelo advento de guerras e, principalmente, pela Peste Negra. A servidão recuou muito na Europa a oeste do Elba, convivendo com o trabalho livre. Entretanto, o suporte da sociedade feudal não ruiu de imediato. Persistiu por séculos, assim como as instituições que the eram correlatas, até que o capitalismo, plenamente desenvolvido, estabeleceu seu império na modernidade.

Com as Grandes Navegações, possibilitadas pelos avanços tecnológicos da época (bússola, astrolábio e novas técnicas de navegação) e impulsionadas pela necessidade dos comerciantes de quebrarem o monopólio veneziano no intercâmbio com o Oriente, a burguesia se fortaleceu enormemente. A lucratividade dos novos empreendimentos era exorbitante ${ }^{49}$, e a área de atuação dos mercados estendeu-se, paulatinamente, para a América, África e Ásia, sobretudo para as duas primeiras. Foi neste momento que Portugal, Espanha, Holanda, Inglaterra e França despontaram à eminência comercial.

Mas estes novos empreendimentos eram também muito custosos, e demandavam um volume muito maior de capitais. As respostas encontradas nos séculos XVI e XVII foram as sociedades por ações, o endividamento público e o crédito bancário. Este último, inclusive, tornou-se decisivo não só nas transações econômicas. Graças aos engenhos militares baseados na pólvora, a atividade bélica tornou-se bastante onerosa. "Por obra das armas de fogo", diz o pensador Robert Kurz, "alterou-se profundamente a estrutura dos exércitos. Os beligerantes não podiam mais se equipar por si próprios e tinham de ser providos de armas por um poder social centralizado ${ }^{50 "}$. O dinheiro da burguesia, assim, foi o fiel da balança em diversas guerras, tendo no Estado um demandante voraz.

\footnotetext{
${ }^{48}$ CASTEL, Robert. As metamorfoses da questão social: uma crônica do salário. Tradução de Iraci D. Poleti. Petrópolis: Vozes, 1998, p. 110.

${ }^{49}$ Lembrando que o lucro comercial no período pré-capitalista advém de trocas desiguais e de operações de rapinagem. Diferentemente do que ocorre na era capitalista, em que o lucro comercial é deduzido da mais-valia formada no chão de fábrica.

${ }^{50}$ KURZ, Robert. Os últimos combates, 5..$^{\text {a }}$ ed.. Tradução de José Marcos Macedo. Petrópolis: Editora Vozes, 1998, p. 242.
} 
Apesar do acúmulo de poder econômico e político pela burguesia no período, importa esclarecer que isto sucedeu no interior de comunidades onde ainda predominava o feudalismo. Mesmo na Inglaterra, pioneira da produção capitalista, as mercadorias ainda não eram predominantemente produzidas na perspectiva do capitalismo ${ }^{51}$. A distinção marxiana entre subsunção formal do trabalho ao capital e subsunção real do trabalho ao capital enseja o bom entendimento do que estamos afirmando. Na primeira, o capital opera como mero consumidor do que se produz artesanalmente, conservando a independência de quem produz. Na segunda, o capital se assenhoreia do processo produtivo, inclusive no tocante à técnica de produção. Comanda-lhe inteiramente pelas exigências da valorização, e por isso a manufatura foi a primeira forma de produção propriamente capitalista, inaugurando a era da exploração da mão-de-obra à maneira capitalista.

Percebe-se, então, que o capitalismo nasce com a produção capitalista, e aqui não há nenhuma redundância. O marxismo vivenciou uma interessante tertúlia historiográfica protagonizada por Paul Sweezy e Maurice Dobb, sobre a qual muitos autores incidiram, dentre eles, destacadamente, Robert Brenner. Examinaremos brevemente este debate, adotando como referência o trabalho de Eduardo Barros Mariutti ${ }^{52}$.

De acordo com Sweezy, a transição do feudalismo ao capitalismo foi conduzida, determinantemente, pelo comércio em ampla escala, que teria subvertido a lógica interna da sociedade feudal, baseada que era na produção de valores de uso. Este tipo de sociedade, por repousar em mecanismos de reprodução social tidos como demasiado estáveis (a servidão feudal e a precária técnica produtiva vigente), não poderia gestar em si nenhum antagonismo capaz de desencadear sua própria superação. Somente a intervenção de elementos externos poderia trazer as mudanças mais significativas, e por isso a expansão comercial teria sido decisiva.

Com efeito, o próprio Marx identificou no comércio o seu potencial desagregador e desestabilizador em face de comunidades tradicionais. Mas isto não o impediu de rechaçar expressamente a hipótese de Sweezy:

\footnotetext{
51 "No todo, entretanto, parece evidente que naquele século [XVII] a indústria doméstica na Inglaterra, em vez de fábrica ou oficina manufatureira, continuou sendo a forma mais típica de produção" (DOBB, Maurice. A evolução do capitalismo. Tradução de Affonso Blacheyre. Rio de Janeiro: Zahar, 1965, p. 179).

${ }^{52}$ MARIUTTI, Eduardo Barros. Balanço do debate: a transição do feudalismo ao capitalismo. São Paulo: Hucitec, 2004.
} 
As descobertas geográficas, por certo, provocaram grandes revoluções no comércio e maior velocidade no desenvolvimento do capital mercantil, e estas transformações constituíram fator fundamental de aceleração da passagem do modo feudal de produção para o capitalista. Mas justamente esse fato levou a concepções de todo errôneas. A expansão súbita do mercado mundial, a multiplicação das mercadorias em circulação, a luta entre as nações européias para se apoderarem dos produtos asiáticos e dos tesouros americanos, o sistema colonial, contribuíram substancialmente para derrubar as barreiras feudais da produção. Entretanto, o moderno modo de produção, em seu primeiro período, o manufatureiro, só se desenvolveu onde se tinham gerado as condições apropriadas no curso da Idade Média ${ }^{53}$.

Marx deixa claro, como se vê, que a concentração de mercadorias nas mãos de uma burguesia não é condição suficiente para que o capitalismo se desenvolva. Aliás, o teórico alemão vai além, propondo que a exacerbação do capital em sua forma comercial ou mercantil é sintoma de uma sociedade que não conhece a capitalização do seu processo produtivo ${ }^{54}$.

A estrutura social feudal não pode ser ignorada, e parece ser esta a preocupação do fundador do materialismo histórico quando atenta para o fato de que "o capital dinheiro, formado por meio da usura e do comércio, era impedido de se transformar em capital industrial pelo sistema feudal no campo e pela organização corporativa da cidade ${ }^{55 ",}$, sendo que tais entraves só cairiam com a dissolução da vassalagem e com a expulsão dos camponeses de suas terras.

Maurice Dobb, por sua vez, seguiu mais de perto a posição marxiana ${ }^{56}$. Sua análise privilegia as contradições internas do modo de produção feudal, pois entende que os resultados dos embates entre senhores e servos foram preponderantes na passagem para o capitalismo. A influência do comércio, neste diapasão, só poderia ser fecunda na medida em que a organização social assim

${ }^{53}$ C., III, V, pp. 443-444.

54 "O desenvolvimento autônomo e preponderante do capital como capital comercial significa que a produção não se subordina ao capital, que o capital, portanto, se desenvolve na base de uma forma social de produção a ele estranha e dele independente. O desenvolvimento autônomo do capital mercantil está, portanto, na razão inversa do desenvolvimento econômico geral da sociedade" (C., III, $\mathrm{V}$, p. 438).

${ }^{55}$ C., I. II, pp. 864-865.

${ }^{56}$ Eduardo Mariutti identifica corretamente uma viragem nas teses de Marx sobre a transição. Se nos trabalhos iniciais predominava uma concepção que privilegiava o desenvolvimento das forças produtivas e da divisão do trabalho, nos trabalhos de maturidade o fator da contradição no interior de uma forma social de produção (luta de classes) ganha realce. A segunda tendência é claramente a que melhor utiliza o método dialético, pois percebe a sociedade nova como erigida sobre os escombros da sociedade velha, quer dizer, como fruto do desenvolvimento das contradições que levaram o mundo velho a perecer e que, ao mesmo tempo, providenciaram a gênese do mundo novo. Diz Mariutti: "Podemos concluir que, no plano lógico, os elementos que constituem um modo de produção são obrigatoriamente gerados durante a crise do sistema que o precedeu" (MARIUTTI, Op. Cit., 2004, p. 180). 
permitiu. O efeito dissolvente de uma torrente de mercadorias "depende, antes de mais nada, da solidez e da estrutura interna do antigo modo de produção ${ }^{57 " .}$.

Não se pode olvidar que as relações servis sufocavam as unidades produtivas e desviavam a maior parte dos recursos da produção para a esfera do consumo improdutivo. A nobreza via no aumento da exploração do produtor direto o único meio de manter o luxo e a prodigalidade, e isto por conta da própria natureza de uma economia baseada em valores de uso. Investir na produtividade como meio de intensificar a extração de sobretrabalho é medida concebível tão somente no capitalismo já consolidado, quando a manufatura cede lugar à indústria e quando o governo da economia pelo valor cria a modalidade da mais-valia relativa. Eis porque o baronato intensificou continuamente a espoliação sobre as classes produtivas, ensejando a fuga de servos para a cidade, em algumas ocasiões, ou uma pauperização suficientemente drástica para abalar a reprodução social no seu conjunto, o que acarretou iniciativas extravagantes, como os cercamentos. Ambos os expedientes colaboraram para a formação do contingente necessário para a exploração da força de trabalho nas manufaturas, agora completamente nua e desgarrada de obrigações feudais. Finalmente o capital deparava-se com a força de trabalho enquanto mercadoria. A esfera da produção, neste instante, abriu suas portas para a burguesia.

A conclusão a que se pode chegar é a de que o capitalismo só se firma na história quando o capital invade e assume o controle da produção, o que só é possível quando os produtores diretos estejam imersos em condições favoráveis para tanto. Indubitavelmente, foi graças à constituição histórica do proletariado que o modo capitalista de produção conseguiu se erigir.

Como citamos de passagem, uma parcela da classe proletária é originária dos artesãos que passaram a ser explorados por seus mestres nas corporações de ofício (mestres que, na lógica feudal, "degeneraram”, é dizer, lançaram-se à acumulação de capital). Não é daí, todavia, que a classe proletária provém majoritariamente, tampouco do ócio e imprevidência de seus antepassados, como presume a lenda liberal.

Refutando a tese absurda de que, num longínquo passado, uma elite laboriosa e parcimoniosa amealhou riquezas, enquanto que uma massa de vadios e

\footnotetext{
${ }^{57}$ C., III, V, p. 443.
} 
pródigos teria desperdiçado suas oportunidades, Marx percebe que "a chamada acumulação primitiva é apenas o processo histórico que dissocia o trabalhador dos meios de produção", e que "é considerada primitiva porque constitui a pré-história do capital e do modo de produção capitalista ${ }^{58 " . ~ E n t r e t a n t o, ~ e s t a ~ d i s s o c i a c ̧ a ̃ o ~ s e ~ d e u ~}$ pela violência nua e crua, sendo inscrita "a sangue e fogo nos anais da humanidade". Os camponeses foram expulsos de suas terras, as quais passaram a integrar o circuito mercantil, inicialmente, pelos arrendamentos. Buscando a sobrevivência no meio urbano, amargaram condições de miséria, tornando-se sujeitos a compor as fileiras do exército industrial.

Ademais, foi importantíssima a participação do Estado, rebaixando os salários e estendendo as jornadas de trabalho compulsoriamente, com legislações sanguinárias, além de ter promovido a expropriação colonial de inúmeras populações fora da Europa ${ }^{59}$. A força se apresentou como uma verdadeira "potência econômica", como uma "parteira" da nova sociedade, e a classe proletária foi o produto desta violência originária.

Uma vez consolidada a estrutura de classes do capitalismo que deu ensejo às manufaturas e, posteriormente, à industrialização, a subsunção real do trabalho ao capital fez-se presente, propiciando o regime de produção tipicamente capitalista. Marx observa que a força de trabalho do trabalhador da manufatura não funciona se não estiver vendida ao capital e que ela só opera dentro da oficina do empregador e em conformidade com a técnica do patrão. O resultado é que este trabalhador só consegue desenvolver sua atividade produtiva como "acessório da oficina do capitalista".

Reproduzimos abaixo a explanação mais detalhada destes efeitos:

O que perdem os trabalhadores parciais, concentra-se no capital que se
confronta com eles. A divisão manufatureira do trabalho opõe-lhes as forças
intelectuais do processo material de produção como propriedade de outrem
e como poder que os domina. Esse processo de dissociação começa com a
cooperação simples, em que o capitalista representa, diante do trabalhador
isolado, a unidade e a vontade do trabalhador coletivo. Esse processo
desenvolve-se na manufatura, que mutila o trabalhador, reduzindo-o a uma
fração de si mesmo, e completa-se na indústria moderna, que faz da ciência

${ }^{58}$ C., I, II, p. 828.

59 "As descobertas de ouro e prata na América, o extermínio, a escravidão das populações indígenas, forçadas a trabalhar no interior das minas, o início da conquista e pilhagem das Índias Orientais e a transformação da África num vasto campo de caçada lucrativa são os acontecimentos que marcaram os albores da era da produção capitalista. Esses processos idílicos são fatores fundamentais da acumulação capitalista" (C., I, II, p. 864). 
uma força produtiva independente de trabalho, recrutando-a para servir ao capital $^{60}$.

A industrialização não é mais do que o prolongamento desse processo de mutilação do trabalhador enquanto ser produtivo, e a revolução industrial deve ser pensada nesta perspectiva, e não como a decorrência imediata e necessária dos melhoramentos tecnológicos ${ }^{61}$. Trata-se de um fenômeno social e historicamente condicionado, longe de ser um desdobramento da técnica, e que foi dirigido pelo imperativo de extração crescente de mais-valia do trabalho humano. Daí porque, nas relações sociais capitalistas, a maquinaria não só não poupa a maioria da humanidade do fardo dos trabalhos rudes, como também reforça o papel do homem como acessório na produção, como um "apêndice da máquina". Tudo para maximizar a valorização do capital.

O crescimento industrial foi capitaneado, nas diferentes nações, por fabricantes de mercadorias de consumo de massa (principalmente produtos têxteis), porque o mercado para tais mercadorias já existia e os homens de negócios podiam ver claramente suas possibilidades de prosperar. Quanto ao protagonismo britânico no início, ele se explica pelas atividades agrícolas predominantemente dirigidas para o mercado (arrendatários empregavam camponeses sem terra e pequenos agricultores), pela disseminação das manufaturas por um interior não feudal e por uma agricultura com produtividade apta para abastecer a população crescente nas cidades e para fornecer trabalhadores "em excesso" para a indústria. No mais, pesou ainda a revolução inglesa do século $X \mathrm{VII}{ }^{62}$, que eclode com o movimento cromwelliano e encontra seu desfecho na coroação de um Guilherme de Orange tolhido de poderes absolutos pelo parlamento burguês.

\footnotetext{
${ }^{60}$ C., I, I, p. 416.

61 "Felizmente poucos refinamentos intelectuais foram necessários para se fazer a revolução industrial. Suas invenções técnicas foram bastante modestas, e sob hipótese alguma estavam além dos limites de artesãos que trabalhavam em suas oficinas ou das capacidades construtivas dos carpinteiros, moleiros e serralheiros: a lançadeira, o tear, a fiadeira automática. Nem mesmo sua máquina cientificamente mais sofisticada, a máquina a vapor rotativa de James Watt (1784), necessitava de mais conhecimentos de física do que os disponíveis então há quase um século (...). Dadas as condições adequadas, as inovações técnicas da revolução industrial praticamente se fizeram por si mesmas, exceto talvez na indústria química" (HOBSBAWM, Eric J.. A era das revoluções: Europa 1789-1848, 12a . ed.. Tradução de Maria Tereza Lopes Teixeira e Marcos Penchel. Rio de Janeiro: Paz e Terra, 2000, pp. 46-47).

62 "Embora verdade que a revolução burguesa na Inglaterra do século XVII percorreu distância relativamente pequena em sua política econômica e social, ela conseguira o bastante para acelerar muitíssimo o crescimento do capital industrial no meio século seguinte (...) e preparar o terreno para a revolução industrial no século seguinte" (DOBB, Op. Cit., 1965, p. 218).
} 
Logo se vê que a afirmação histórica da burguesia exigiu luta política, e a experiência francesa aponta este fato em sua radicalidade. Não estamos dizendo que esta burguesia tenha sido efetivamente revolucionária, já que a Revolução Francesa foi dirigida e impulsionada por camadas populares e pequeno-burguesas, sem falar que a ambição dos grandes empresários sempre se restringiu a uma monarquia constitucional. O que importa aqui foi a necessidade do malogro do Antigo Regime para que o modo de produção capitalista pudesse explorar melhor suas potencialidades. E como nenhuma classe renuncia a seus privilégios pacificamente, o embate com a aristocracia de origem feudal foi inevitável.

Excetuando-se a prematura experiência inglesa, tal embate se inicia com mais radicalidade na França e logo se espalha pelo continente: a nobreza europeia investe contra a revolução, a revolução se defende e se fortalece, encerrando-se com o Termidor. Ao derrotar os "excessos" do jacobinismo, a classe burguesa garantiu uma estabilidade interna temporária e arquitetou um arranjo institucional que lhe era conveniente, sendo oposto à institucionalidade feudal. As obras da era napoleônica, inspiradas nas linhas ideológicas da Declaração dos Direitos do Homem e do Cidadão (o grande marco ideológico da Revolução Francesa), assim o demonstram: as codificações, as cortes de Justiça, o funcionalismo estatal, o sistema financeiro nacional, a infra-estrutura educacional etc. Aí está a formação do Estado burguês moderno com seus traços mais exatos e definidos, que só vieram a triunfar com a completa destruição do Estado feudal absolutista.

Também foi indispensável um combate externo, em que os exércitos de Napoleão atuaram para estabelecer um mercado europeu para a nascente indústria francesa e para instaurar regimes aliados. Ao final, a vitória da contrarrevolução aristocrática na Europa apenas prolongou a agonia do poder nobiliárquico, cuja decadência era irreversível àquela altura da história e do estágio atingido pelas relações burguesas. O triunfo pelas armas não era capaz de conter as novas forças desencadeadas pela indústria capitalista ${ }^{63}$.

\footnotetext{
63 "A grande indústria criou o mercado mundial, preparado pela descoberta da América. O mercado mundial expandiu prodigiosamente o comércio, a navegação e as comunicações. Por sua vez, esse desenvolvimento repercutiu sobre a extensão da indústria, e à medida que indústria, comércio, navegação e ferrovia se desenvolviam, a burguesia crescia, multiplicava seus capitais e relegava para o segundo plano as classes tributárias da Idade Média" (MARX, Karl; ENGELS, Friedrich. Manifesto do Partido Comunista. Tradução de Sueli Tomazzini Barros Cassal. Porto Alegre: L\&PM, 2006, pp. 25-26).
} 
As referidas forças não englobavam apenas a burguesia industrial. $O$ proletariado fez sentir seu peso enquanto sujeito social no período imediatamente posterior, e a Primavera dos Povos de 1848 forçou inúmeros regimes burgueses e aristocráticos a introduzir alterações em seu quadro institucional. O sufrágio universal e os direitos sindicais enfim emergiram, inaugurando uma nova época para o processamento da política, na medida em que legalizava a luta de classes, ao menos em parte.

Os desdobramentos políticos e jurídicos de todas estas transformações serão debatidos nos itens seguintes deste capítulo. No entanto, por uma mera questão de datação histórica se consegue entrever que as declarações de direitos e as constituições liberais são contemporâneas do modo de produção capitalista em seu processo de construção, que passa pela revolução industrial e pelas revoluções burguesas. Resta saber quais as implicações deste fato para o mundo dos direitos humanos.

\subsection{A natureza de classe dos direitos civis e políticos}

Uma vez delineado o contexto histórico e material dos direitos civis e políticos, cumpre investigar sua natureza social: se são efetivamente universais, ou seja, se de fato se reportam aos interesses de toda a humanidade, ou se são perpassados por um recorte de classe que desmente o seu discurso, colocando o modo como se apresentam em franca contradição com a sua essência. Vejamos de perto este discurso.

Lê-se na teoria tradicional dos direitos humanos, que ora ilustramos com a obra de Fábio Konder Comparato, que o artigo I da Declaração de Direitos de Virgínia de 1776 "constitui o registro de nascimento dos direitos humanos na História ${ }^{64 " . ~ V e j a-s e ~ s u a ~ r e d a c ̧ a ̃ o: ~}$

Todos os seres humanos são, pela sua natureza, igualmente livres e independentes, e possuem certos direitos inatos, dos quais, ao entrarem no estado de sociedade, não podem, por nenhum tipo de pacto, privar ou despojar sua posteridade; nomeadamente, a fruição da vida e da liberdade, com os meios de adquirir e possuir a propriedade de bens, bem como de procurar e obter a felicidade e a segurança ${ }^{65}$.

\footnotetext{
${ }^{64}$ COMPARATO, Op. Cit., 2010, p. 62.

65 Todas as citações de trechos de declarações de direitos que utilizarmos doravante serão reproduzidas do livro "A afirmação histórica dos direitos humanos".
} 
Com efeito, a independência dos Estados Unidos da América antecedeu a Revolução Francesa, e a ideologia burguesa já está toda lá. A concepção individualista do homem, a metáfora contratualista (neste caso, de inspiração na filosofia de John Locke) e a adoração da propriedade privada (sem a qual não se concebe a fruição da vida e da liberdade) dão forma ao indivíduo burguês, o "proprietário abstrato e transposto para as nuvens" de que falava Pasukanis a partir do eixo "liberdade-igualdade-propriedade-Bentham" de que falava Marx. O que se introduz como novidade agora é a absolutização desta imagem. A condição do sujeito de direito é tida como inata ao homem, ou seja, advém de sua natureza.

No tocante à Declaração dos Direitos do Homem e do Cidadão de 1789, que também proclama que os homens nascem livres e iguais em direitos no seu dispositivo inicial, a absolutização é ainda mais intensa. Já no preâmbulo, considerase que "a ignorância, o descuido ou o desprezo pelos direitos humanos são as únicas causas das desgraças públicas e da corrupção dos governos", cabendo à Assembleia Nacional reconhecer e declarar, "na presença e sob os auspícios do Ser Supremo", os direitos do Homem e do Cidadão.

$\mathrm{Na}$ visão de Comparato, o que se passa é somente o reconhecimento solene de um mesmo conceito de dignidade cuja origem remete à Antiguidade. Seria a partir do "período axial" ${ }^{66 "}$ que o ser humano passaria a ser considerado, "em sua igualdade essencial, como ser dotado de liberdade e razão, não obstante as múltiplas diferenças de sexo, raça, religião ou costumes sociais ${ }^{67 ", ~ e s t a n d o ~ p o s t o s, ~}$ então, os fundamentos intelectuais para a pessoa humana e seus direitos. Certamente, um pensador imbuído de preocupações humanistas está sujeito a se inclinar perante aproximações entre filosofias de tempos e realidades distantes para defender, com a melhor das intenções, a justeza da dignidade do homem e o apreço por sua figura. Este caminho, apesar de tentador, é bastante incorreto. Engels não se deixa enganar:

A crença de que todos os homens, pelo simples fato de sê-lo, têm alguma coisa de comum que os torna iguais, na proporção em que exista êsse ponto comum, é naturalmente antiquíssima. Mas o postulado moderno da

\footnotetext{
${ }^{66} \mathrm{O}$ autor utiliza uma nomenclatura proposta por Karl Jaspers, que divide o curso inteiro da história mundial em duas etapas, tendo como divisor de águas o período entre os séculos VIII e II a.C.. Este período formaria o eixo histórico da humanidade, e por isso é designado como axial.

${ }^{67}$ COMPARATO, Op. Cit., 2010, pp. 23-24.
} 
igualdade difere radicalmente desta idéia e, pelo contrário, faz ressaltar da própria natureza, comum a todos os homens, dessa igualdade dos homens como tais, o princípio da equiparação política e social de todos os sêres humanos, ou, pelo menos, de todos os cidadãos de um Estado, ou de todos os indivíduos de uma mesma sociedade ${ }^{68}$.

A noção de igualdade humana e de direitos do homem, este "princípio de equiparação política e social", só pôde prosperar com o capitalismo ${ }^{69}$. A burguesia inscreveu estes direitos em sua bandeira de guerra contra os resquícios feudais do Antigo Regime. Era preciso quebrar os privilégios e as barreiras alfandegárias que inibiam o livre fluxo comercial e o fortalecimento das manufaturas, além de liberar definitivamente a terra e a força de trabalho para o mercado e, por conseguinte, para a valorização do capital. Os direitos humanos anunciados nos movimentos de revolução burguesa, neste sentido, são os caracteres do sujeito de direito promovidos a expoentes da civilização capitalista, sempre embebidos num fetichismo jurídico em grau extraordinário. Este fetiche, que mais se assemelha a uma teologia laicizada nas declarações, encontra-se justamente no encanto desta fórmula universal que invoca todos os homens.

Norberto Bobbio, consagrado apologista da ordem burguesa, oferece uma boa noção do que dizemos em sua defesa apaixonada dos monumentos da civilização capitalista. Em seu livro $A$ era dos direitos, ele informa que a Declaração dos Direitos do Homem e do Cidadão foi atacada tanto pelos conservadores e reacionários quanto pela esquerda e por Marx, embora por razões diferentes. A crítica pela esquerda, que estaria sintetizada na obra "A questão judaica" e que denuncia que o homem individualista do documento em tela consiste no indivíduo burguês egoísta, seria infundada pelos argumentos abaixo:

Também a crítica marxista não captava o aspecto essencial da proclamação dos direitos: eles eram expressão da exigência de limites ao superpoder do Estado, uma exigência que, se no momento em que foi feita podia beneficiar a classe burguesa, conservava um valor universal. Basta ler o primeiro dos artigos que se referem à liberdade pessoal: 'Ninguém pode ser acusado, preso e detido senão nos casos determinados pela lei, etc.' (é o artigo que consagra o princípio do 'garantismo', 'nulla poena sine lege'); depois, pode-se meditar sobre o

${ }^{68}$ ENGELS, Friedrich. Anti-Dühring: filosofia, economia política, socialismo, 2ª ${ }^{\text {a }}$ ed.. Rio de Janeiro: Paz e Terra, 1990, p. 87.

69 "A origem dos direitos humanos está, portanto, no próprio funcionamento da circulação mercantil generalizada. A liberdade, a igualdade e a propriedade surgem como prerrogativas do sujeito econômico egoísta, prerrogativas determinadas pelo próprio mercado que constitui o sujeito econômico" (KASHIURA JÚNIOR, Celso Naoto. Crítica da Igualdade Jurídica: contribuição ao pensamento jurídico marxista. São Paulo: Quartier Latin, 2009, p. 123). 
que ocorreu nos países em que são (ou ainda são) evidentes as funestas consequências do desprezo por tais princípios, já que o questionamento de sua universalidade atinge indiscriminadamente tanto os burgueses quanto os proletários ${ }^{70}$.

O mau procedimento de Bobbio é assombroso. O notório jusfilósofo ataca uma formulação marxista com base em apenas uma obra, tendo a infelicidade de escolher uma em que o método marxista ainda não se faz presente em sua inteireza. Mas mesmo numa abordagem eivada de alguns vícios idealistas, o Marx de $A$ questão judaica enxergou muito além do que permitiram as lentes embaçadas do teórico italiano. A crítica marxiana naquele texto traz em si inquietações que em momento algum acometem Bobbio: por que deve haver uma separação entre homem e cidadão, entre homem e comunidade? Por que os direitos naturais e imprescritíveis do homem devem ser a liberdade, a igualdade, a propriedade e a segurança, e isto na constituição radical de 1793 ?

Ao invés de idolatrar estes direitos, Marx busca compreendê-los. A liberdade humana é colocada como "o poder pertencente ao homem de fazer tudo o que não prejudica os direitos alheios" (art. 6), cabendo à lei desenhar estes limites. Ora, o que se tem é um direito humano à liberdade que "não se baseia na vinculação do homem com o homem, mas, antes, no isolamento do homem relativamente ao homem", de sorte que "cada homem encontre no outro homem, não a realização, mas antes a barreira da sua liberdade ${ }^{71}$ ". Outrossim, a igualdade significa que cada homem seja igualmente uma mônada que repousa sobre si, que seja igualmente um átomo voltado aos cuidados de si mesmo. A propriedade é o direito ao desfrute do patrimônio conforme o interesse pessoal, e a segurança é o princípio que converte a sociedade em meio para que o indivíduo dê vazão à mesquinharia embutida nas relações sociais e consagre o isolamento de sua vida na fruição de seus direitos.

Registre-se que somente com as observações feitas em $O$ Capital, muito bem aproveitadas por Pasukanis, é que se pode conhecer o substrato material dos "direitos do homem" e de sua orientação egoísta. Não obstante, o texto criticado por Bobbio, se bem compreendido, já é suficiente para ir além da ideologia burguesa que envolve as declarações, trazendo uma contribuição crítica respeitável. Ocorre que o filósofo italiano não o entendeu, assim como não entendeu o marxismo como

\footnotetext{
${ }^{70}$ BOBBIO, Norberto. A era dos direitos. Tradução de Carlos Nelson Coutinho. Rio de Janeiro: Campus, 1992, pp. 125-126.

${ }^{71}$ MARX, Karl. Para a questão judaica. Op. Cit., 2009, p. 64.
} 
um todo. Acreditou, errônea e candidamente, que a crítica marxista seria a de que o proletariado não estaria contemplado pelos direitos humanos, chegando a dizer que bastava uma leitura da Declaração para se perceber que não há cortes pelo critério de classe.

Porém, a questão não é a inclusão ou não do proletariado, e sim como ela se dá. É absolutamente dispensável o exercício de literalidade a que Bobbio convida os marxistas. Ninguém ignora que, juridicamente, as garantias de uma constituição moderna são aplicáveis a todos os cidadãos. Entre esse belo enunciado e o mundo prático, no entanto, existe um abismo preenchido por inúmeras mediações, e a principal delas, como pretendemos demonstrar em breve, é o conflito de classe. Afinal, um regime político não é o que ele diz de si mesmo nas constituições que promulga e nos tratados que assina. Ele é aquilo que a realidade material e seus antagonismos determinam que ele seja. Se a liberdade e a igualdade contida nos direitos humanos de primeira dimensão decorrem da circulação e da produção mercantis, é mister ao menos cogitar os limites destes direitos, o que será feito mais adiante. Há de se demonstrar que a liberdade e a igualdade dos direitos humanos curvam-se às necessidades do mercado capitalista, e não da humanidade.

Bobbio se enche de júbilo ao ensinar que o aspecto essencial da proclamação dos direitos humanos de primeira dimensão é colocar freios no poder do Estado. Afirma ainda que esta exigência, num primeiro instante, até poderia beneficiar a classe burguesa, mas isto não afastaria o valor universal dos direitos do homem. Caso o autor estivesse atento para a lógica dos eventos históricos, não teria se deixado enfeitiçar por este senso comum. Se a classe burguesa, como vimos, estava em luta contra as estruturas feudais, não poderia lhes combater parcialmente. Não há nada no ambiente feudal que interesse ao capital, e por isso as instituições medievais caíram por terra, uma a uma, na proporção em que o capitalismo se desenvolvia. Logo, a extensão dos benefícios da derrocada do Antigo Regime forçosamente atingiria as outras classes, até mesmo porque, em alguns casos, coube ao proletariado o protagonismo desta transformação (como na Rússia de 1917). Com a queda do feudalismo, cedo ou tarde as classes laboriosas seriam liberadas da servidão e das formas correlatas de controle político, o que não quer dizer que não seriam submetidas a outra modalidade de exploração, com seus mecanismos políticos particulares. Naquilo que Norberto Bobbio enxerga uma consequência lógica do valor universal dos direitos humanos, o materialismo 
histórico revela a disputa por mão-de-obra, algo muito menos romântico. Observe-se esta citação de Engels, tão longa quanto reveladora:

\begin{abstract}
A emancipação dos entraves feudais e a implantação da igualdade jurídica, pela abolição das desigualdades do feudalismo, eram um postulado colocado na ordem do dia pelo progresso econômico da sociedade, e que depressa alcançaria grandes proporções. Embora proclamado êste postulado da igualdade de direitos no interêsse da indústria e do comércio, não havia mais remédio senão torná-lo extensivo também à grande massa de camponeses que, submetida a tôdas as nuanças de vassalagem, que chegava até a servidão completa, passava a maior parte de seu tempo trabalhando gratuitamente nos campos do nobre senhor feudal, além de ter de pagar a êle e ao Estado uma infinidade de tributos. Postos neste caminho, não havia outro remédio para os burgueses senão exigir também a abolição dos privilégios feudais, da isenção de impostos para a nobreza, dos direitos políticos singulares de cada categoria social feudal. E como a sociedade não vivia mais num império mundial como o romano, mas sim dividida numa rêde de Estados independentes, que mantinham entre si relações de igualdade e tinham chegado a um grau quase burguês de desenvolvimento, era natural que aquelas tendências adquirissem um caráter geral, ultrapassando as fronteiras dos Estados e era natural, portanto, que a liberdade e a igualdade fossem proclamadas direitos humanos. Para compreender o caráter especificamente burguês de tais direitos humanos, nada mais eloqüente que a Constituição norte-americana, a primeira em que são definidos os direitos do homem, na qual, ao mesmo tempo, se sanciona a escravidão dos negros, então vigente nos Estados Unidos, e se proscrevem os privilégios de classe, enquanto que os privilégios de raça são santificados ${ }^{72}$.
\end{abstract}

Em resumo, não se pode servir a dois senhores. A burguesia não podia partilhar sua mão-de-obra com a nobreza. Adicionando-se a este fator a transcendência territorial da forma mercantil, que não faz cerimônia para se inserir neste ou naquele Estado, dá-se por desmistificado o caráter universalista dos direitos humanos. Resta imaginar como Bobbio tentaria se desvencilhar do encurralamento em que a menção de Engels sobre a escravatura coloca sua tese. A Declaração dos Direitos do Homem e do Cidadão que lhe é tão cara não pode ser pensada separadamente das Cartas norte-americanas (Declaração de Independência, Declaração de Direitos de Virgínia e o Bill of Rights da Constituição estadunidense), todas atravessadas pelo espírito liberal da burguesia. Tanto nas colônias da França ${ }^{73}$ como nos EUA, os direitos do homem conviveram muito bem com a escravidão e ignoraram a tal dignidade humana. Como escravos não portam mercadorias (ao contrário, eles próprios são oferecidos no mercado), não são

\footnotetext{
${ }^{72}$ ENGELS, Op. Cit., 1990, p. 89.

${ }^{73}$ A escravidão nas colônias francesas foi abolida apenas cinco anos depois da Declaração de 1789 , graças à radicalização jacobina. Em 1802, foi reinstituída pelo então cônsul Napoleão, perdurando até o ano de 1848.
} 
dignos, para o capitalismo, de portar direitos. Não há valor universal que se ocupe deles.

Em Engels e Marx, portanto, o caráter de classe dos direitos humanos é apresentado em franco contraste com o discurso liberal idealista. Todavia, se nossos liberais mais recalcitrantes não se sentem confortáveis com a abordagem marxista, é recomendável que examinem os escritos de Thomas Paine, um de seus representantes oficiais.

Paine foi um dos ideólogos do movimento de independência dos Estados Unidos, donde se originou a Declaração de Virgínia, em que se registrou, pela primeira vez num documento oficial, a concepção burguesa de mundo e de homem (vide a transcrição de seu artigo primeiro no início do tópico). Como bom liberal, o autor professa que a sociedade é uma benção, enquanto que o governo é um "mal necessário"; que a melhor forma de governo é a que garante segurança pelo menor custo e pelo maior benefício; que sua origem é a incapacidade da virtude moral para governar e que seu propósito é a segurança dos indivíduos enquanto proprietários ${ }^{74}$.

Militante da causa da independência, Paine ataca a coroa inglesa, num primeiro instante, com uma crítica à figura da monarquia em si, destacando a irracionalidade das instituições que lhe são inerentes. É nesta toada que vai o seu panfleto, até que, esgotada a argumentação no âmbito da filosofia política, envereda diretamente para os interesses materiais, desafiando aqueles que eram favoráveis à reconciliação com a metrópole:

\begin{abstract}
Desafio o mais ardoroso defensor da reconciliação a apresentar uma única vantagem que este continente possa colher da sua ligação com a GrãBretanha. Reitero o desafio: não se tira uma só vantagem. O nosso milho alcançará o seu preço em qualquer mercado da Europa, e os bens que importamos terão de ser pagos onde quer que os compremos.

Mas os prejuízos e as desvantagens que sofremos com essa ligação são incontáveis, e o nosso dever com relação à humanidade como um todo, bem como a nós mesmos, instrui-nos para renunciarmos à aliança, porque qualquer submissão à Grã-Bretanha, ou dependência dela, tende diretamente a envolver este continente em guerras e disputas européias,
\end{abstract}

\footnotetext{
74 "O governo, como uma vestimenta, é o emblema da inocência perdida; os palácios dos reis são construídos sobre as ruínas das moradas do paraíso. Se os impulsos da consciência fossem obedecidos de forma clara, uniforme e irresistível, ninguém necessitaria de outro legislador. Como não é esse o caso, os homens consideram necessário ceder uma parte de sua propriedade a fim de fornecer meios para a proteção do restante. A isso são levados pela mesma prudência que os aconselha, em qualquer outro caso, a escolher, dentre dois males, o menor. Conseqüentemente, sendo a segurança o verdadeiro propósito e finalidade do governo, segue-se irrefutavelmente que qualquer que seja a forma de governo que, com maior probabilidade, nos garantirá a segurança, com os menores custos e os maiores benefícios, ela será preferível a todas as demais" (PAINE, Thomas. Senso comum. Tradução de Ricardo Doninelli-Mendes. Porto Alegre: L\&PM, 2009, p. 11).
} 
pondo-nos em desacordo com nações que, caso contrário, procurariam a nossa amizade, e das quais não temos raiva nem queixa. Como a Europa é o nosso mercado, não devemos formar uma ligação parcial com quaisquer de suas partes. O real interesse da América é manter-se afastada das contendas européias, coisa que não conseguirá enquanto, por sua dependência da Grã-Bretanha, servir de contrapeso na balança das políticas britânicas.

A Europa está demasiadamente povoada de reinos para que a paz seja duradoura. E sempre que irrompe uma guerra entre a Inglaterra e alguma potência estrangeira, o comércio da América arruína-se por causa de sua ligação com a Grã Bretanha ${ }^{75}$.

Não restam dúvidas, pois, de que as Cartas norte-americanas, situadas no seu contexto de luta por independência, deixam entrever que, em verdade, exprimem apenas os anseios de uma burguesia cujo mote de liberdade é reduzível, em última análise, à liberdade comercial e às instituições acessórias (como o princípio do no taxation without representation). As noções de liberdade e igualdade invocadas nas declarações, tanto nos Estados Unidos quanto na França, reportamse à classe burguesa em ascenso.

Quanto ao argumento de Bobbio de que o cerne da Declaração dos Direitos do Homem e do Cidadão é o controle do poder do Estado, de modo a evitar abusos, não conseguimos imaginar nada mais etéreo e alheio à história. Em 1215, o baronato inglês impôs ao seu rei (ao "Estado" da época) um extenso rol de limitações ao exercício de suas faculdades de monarca feudal, e isto nada tem que ver com os direitos humanos, apesar de ser muito comum que o pensamento tradicional veja nesta Magna Carta, na pior das hipóteses, um "antecedente" dos direitos fundamentais. O que há de novo e de característico nas revoluções burguesas é o início da construção do Estado burguês, cujo uso da violência organizada, no seu momento maduro e em condições de normalidade, adquire feições completamente distintas.

Já escrevemos bastante acerca do aspecto geral das declarações e de sua origem histórica e material, mas teremos uma ideia incompleta dos direitos humanos de primeira dimensão se não caminharmos além. Estes direitos se manifestam no formato de liberdades públicas, como direitos civis e políticos. Estão enunciados nas declarações como liberdades em face da autoridade constituída, exprimindo centralmente os valores da liberdade, da igualdade e da propriedade. A liberdade efetiva-se na livre comunicação dos pensamentos, no livre culto, no livre trânsito e

\footnotetext{
${ }^{75}$ PAINE, Op. Cit., 2009, p. 31
} 
no poder de polícia. Esta noção de um poder de polícia pressupõe cidadãos, isto é, indivíduos munidos de direitos, e não súditos. Como os cidadãos são livres, resta à autoridade harmonizar o uso da liberdade, evitar que uma mônada interfira na outra, e em observância a critérios impessoais, com força e forma de lei.

A legitimidade desta lei advém da "vontade geral". No seu artigo sexto, ao colocar a lei como expressão da vontade geral, a Declaração dos Direitos do Homem e do Cidadão estabelece que "todos os cidadãos têm o direito de concorrer pessoalmente, ou por meio de representantes, à sua formação", devendo ela ser a mesma para todos, "quer proteja, quer puna". Numa só tacada, fixam-se a representação popular e a soberania popular. Cada átomo possui sua quota-parte na soberania nacional, embora não possa exercê-la pessoalmente. Aos indivíduos só é dado expor sua vontade pelo voto ou cumprir um mandato para fazer valer a vontade coletiva ${ }^{76}$. Portanto, o sufrágio se soma às demais liberdades como uma instituição-chave para a conformação política da sociedade civil, do agrupamento final de todos os átomos. O povo, abstratamente considerado como o corpo dos cidadãos, assume o lugar que antes era destinado a Deus na fundamentação do regime político. Bobbio justifica esta posição sem se fazer de rogado:

Hoje, o próprio conceito de democracia é inseparável do conceito de direitos do homem. Se se elimina uma concepção individualista da sociedade, não se pode mais justificar a democracia do que aquela segundo a qual, na democracia, os indivíduos, todos os indivíduos, detêm uma parte da soberania ${ }^{77}$.

E prossegue:

Numa democracia, quem toma as decisões coletivas, direta ou indiretamente, são sempre e apenas indivíduos singulares, no momento em que depositam seu voto na urna. Isso pode soar mal para quem só consegue pensar a sociedade como um organismo; mas, quer isso agrade ou não, a sociedade democrática não é um corpo orgânico, mas uma soma de indivíduos. Se não fosse assim, não teria nenhuma justificação o princípio da maioria, o qual, não obstante, é a regra fundamental de decisão democrática. E a maioria é o resultado de uma simples soma aritmética, onde o que se soma são os votos dos indivíduos, um por um ${ }^{78}$.

\footnotetext{
${ }^{76}$ O artigo 26 da Declaração dos Direitos do Homem e do Cidadão da Constituição de 1793 dispõe que "nenhuma parcela do povo pode exercer o poder do povo inteiro; mas cada segmento do soberano, reunido em assembléia, deve gozar do direito de exprimir sua vontade com inteira liberdade".

${ }_{77}^{70}$ BOBBIO, Op. Cit., 1992, p. 101.

${ }^{78}$ BOBBIO, Op. Cit., 1992, p. 102.
} 
Bobbio contrapõe individualistas a anti-individualistas, insinuando que estes últimos, necessariamente, pensam a sociedade como um organismo. Ao fazê-lo, indiretamente afirma que qualquer crítica ao individualismo é reacionária. Sua proposição permite que um crítico como Marx se enquadre no mesmo patamar que um Edmund Burke, o adversário da Revolução Francesa, apegado às tradições e aos costumes.

Nada mais leviano. Construir a crítica de um fenômeno não implica condenálo abstrata e indeterminadamente, e sim indicar os limites que o cercam. O marxismo está longe de advogar a extinção da figura do indivíduo ou de negar a individualidade humana. Só o que faz é apontar que o individualismo das revoluções burguesas, em que pese seu caráter progressista diante do obscurantismo medieval, alberga a exploração capitalista. A proposta para a humanidade que os marxistas defendem, bem ao contrário do que Bobbio imagina, almeja dar vazão ao vigor de cada individualidade com o fim da exploração, e não tolhê-lo.

Reservamos ao capítulo final desta obra o aprofundamento desta questão. Por enquanto, atentemo-nos ao fato de que, para o pensamento burguês hegemônico, o individualismo dos direitos do homem adquire um peso fundamental, projetando-se sobre as instituições políticas. A democracia é inequivocamente condicionada à concepção individualista, e o sufrágio é destacado como o intermediário entre elas, como o mecanismo absoluto que assegura o ambiente democrático.

Alternativamente às lições de aritmética de Bobbio, e dispensando 0 maniqueísmo, Márcio Naves apresenta uma visão crítica sobre o sufrágio. Na medida em que os cidadãos participam das decisões coletivas na democracia burguesa, isto é, exercem sua quota-parte na soberania nacional, "constitui-se um processo de circulação das vontades políticas análogo ao processo de circulação das mercadorias ${ }^{79}$ ", já que a representação, no sufrágio, funda-se na equivalência entre os cidadãos, tal como na equivalência mercantil. Obviamente, não se infere desta conclusão que o princípio "uma cabeça, um voto" seja forçosamente burguês. Ele o é num ambiente dominado pela circulação e pela produção de mercadorias, sem o qual não há igualdade jurídica, tampouco sujeitos de direito. O cidadão nada mais é do que o rosto político, ou público, do sujeito de direito.

\footnotetext{
${ }^{79}$ NAVES, Marxismo e direito: um estudo sobre Pachukanis. Op. Cit., 2008, p. 84.
} 
Voltemos a Bobbio e à doutrina liberal. Se o sufrágio é a base da democracia, então a extensão dele seria capaz de promover uma democracia completa. $O$ autor italiano vai além, afirmando, em mais uma de suas polêmicas com Marx, que a participação do proletariado nas eleições chegaria a modificar o sentido da concepção individualista da sociedade, tornando-a mais proletária que burguesa:

\begin{abstract}
Quanto à interpretação marxiana, ela é uma indébita generalização de uma observação histórica justa: se o contratualismo nasce com o crescimento do mundo burguês (mas quanta indeterminação nesta abusadíssima expressão!), a concepção individualista da sociedade, que está na base da democracia moderna, não é mais burguesa do que uma que seja proletária, ao contrário, é mais proletária que burguesa, já que, enquanto a burguesia governante iria se manter aferrada a um sufrágio limitado apenas aos proprietários, a extensão do sufrágio inclusive aos que nada têm apenas ocorreu com o impulso vindo de baixo propiciado pelo movimento operário. E o sufrágio universal é a condição necessária, se não suficiente, para a existência e o funcionamento regular de um regime democrático, na medida em que é o resultado do princípio fundamental da democracia, segundo o qual fonte de poder são os indivíduos uti singuli e cada indivíduo vale por um (o que, entre outras coisas, justifica a aplicação da regra de maioria para a tomada das decisões coletivas). ${ }^{80}$
\end{abstract}

A conquista do sufrágio universal pelo movimento operário, deste modo, esvaziaria a denúncia de que a democracia liberal é essencialmente burguesa. Afinal, o voto do trabalhador vale tanto quanto o voto do capitalista, e uma vez que a classe do primeiro é majoritária, a legitimidade das eleições estaria assegurada pelo critério da maioria. Já vimos que o caráter burguês da forma jurídica e da imagem do cidadão desmente esta tese. Quanto ao "impulso vindo de baixo", haveria aí um caráter operário que enriqueceria a democracia liberal, que the conduziria a um estágio aperfeiçoado, mais abrangente. Pois bem, ocorre que, apesar de reconhecer o papel da classe proletária no sufrágio universal, fato este que geralmente se esquece nas narrativas sobre o tema, Bobbio ignora um dado importantíssimo:

Com efeito, se bem olharmos, são três as etapas fundamentais que assinalam a conquista do sufrágio universal igualitário: 10 de agosto de 1792, Revolução de Fevereiro de 1848, agitações revolucionárias na Rússia de 1917. Todas estas três datas são estranhas à tradição liberal, que, antes, observa-as com desconfiança ou com aberta hostilidade ${ }^{81}$.

\footnotetext{
${ }^{80}$ BOBBIO, Norberto. O futuro da democracia: uma defesa das regras do jogo. Tradução de Marco Aurélio Nogueira. Rio de Janeiro: Paz e Terra, 1986, p. 145.

${ }^{81}$ LOSURDO, Domenico. Democracia ou bonapartismo: triunfo e decadência do sufrágio universal. Tradução de Luiz Sérgio Henriques. Rio de Janeiro: Editora UFRJ; São Paulo: Editora UNESP, 2004, p. 56. A despeito das conclusões do autor, encontramos na obra uma boa fonte de informações históricas.
} 
Losurdo não parte de acontecimentos que são desconhecidos por seu conterrâneo liberal. O que faz é tão somente frisar que o sufrágio universal se deu apesar do liberalismo, e não em consequência dele. O movimento operário não foi uma força mística que concorreu para o aperfeiçoamento contínuo da democracia liberal, e sim um fator da luta de classes que ensejou uma nova configuração político-institucional para a sociedade. A história do sufrágio universal é um dos momentos da história do conflito entre capital e trabalho, uma longa e extenuante queda-de-braço entre classes. Ao final, a classe trabalhadora venceu, conquistando o direito de abstrair sua condição material nas eleições e de participar da escolha de seus carrascos, ou seja, daqueles a quem o sistema capitalista confia o encargo de manter um ambiente político e econômico adequado à preservação e à expansão do capital.

Os arautos do reformismo, fazendo coro ao liberalismo clássico, hão de objetar-nos que menosprezar esta conquista não seria razoável. Estamos de acordo, e dizemos mais: deixar-se cegar por ela é uma falha simétrica. Não nos é saudosa a época do sufrágio exclusivo das classes possuidoras, e quanto a isso os opositores do marxismo não precisam se preocupar. Novamente, se denunciamos que nem o sufrágio universal e nem a democracia liberal como um todo trouxeram emancipação para as classes laborais, não o fazemos com a aspiração estapafúrdia de fazer retroceder a roda da história. Enquanto os reacionários questionam o presente com os olhos do passado, os revolucionários questionam o presente com os olhos do futuro, de um horizonte que esteja à altura da potência humana em todas as suas conquistas materiais e intelectuais.

Inevitavelmente, a discussão sobre os direitos civis e políticos direcionou nosso estudo para uma discussão sobre a democracia liberal. Estamos longe de travá-la em toda sua complexidade, e não poderemos sequer nos aproximar deste objetivo sem investigar o conceito de Estado de Direito, ao qual nos dedicaremos a seguir.

\subsection{As liberdades democráticas e o Estado de Direito}

Mencionamos anteriormente que o apanágio do Estado burguês seria que, nele, o uso da violência organizada, "no seu momento maduro e em condições de 
normalidade", adquire feições completamente distintas. Chegou o momento de explicarmos melhor esta concepção.

A maturidade do Estado burguês depende fundamentalmente da maturidade do próprio capitalismo, das relações burguesas de produção. É claro, porém, que a construção deste tipo de Estado não foi automática. O que se observa nas revoluções burguesas não é a mera conquista do poder por uma classe, e sim a destruição de instituições oriundas do feudalismo, o que abarca todo o aparato do absolutismo. Vale citar aqui, rapidamente, o debate sobre a natureza do Estado absolutista. Filiamo-nos à tese de que se trata de uma superestrutura feudal, seguindo os argumentos de Armando Boito Junior. O teórico brasileiro demonstra de maneira assaz convincente que a natureza de classe de um tipo de Estado está inscrita nos aparelhos que constituem a arquitetura institucional desse Estado, e não na política por ele implementada. Apontando em Poulantzas a contradição de que, em sua obra, "o Estado absolutista seria um Estado capitalista que organiza a dominação da classe feudal ${ }^{82 ",}$, Boito Junior indica que, sob o absolutismo, prevaleciam traços incompatíveis com a fisionomia do Estado burguês, como o caráter estamental do exército, a venalidade dos cargos estatais, o regime de propriedade parcelar e a adstrição do camponês à terra.

Continuemos. As condições de normalidade do Estado capitalista, por sua vez, referem-se a um momento não conturbado da luta de classes, em que as relações sociais em vigência não estejam sob alguma ameaça, não importando se houver ou não houver embates isolados. Com isso queremos dizer que, em regra, a utilização da força bruta pelo Estado capitalista é feita com vários dispositivos de controle que o diferenciam dos aparelhos estatais de outras formações. Em regra, o Estado de direito se aplica: a contenção dos adversários da ordem precisa passar por expedientes burocráticos e filtros institucionais, a exemplo dos mandados judiciais.

O Estado de direito é frequentemente conceituado, a despeito de alguns matizes dependendo do autor, como "um Estado moderno no qual ao ordenamento jurídico (...) é atribuída a tarefa de 'garantir' os direitos individuais, refreando a natural tendência do poder político a expandir-se e a operar de maneira arbitrária" ${ }^{83 " .}$

\footnotetext{
82 BOITO JR., Op. Cit., 1998 , p. 87.

${ }^{83}$ ZOLO, Danilo. Teoria e crítica do Estado de Direito. In: COSTA, Pietro; ZOLO, Danilo. O Estado de Direito: História, teoria, crítica. Tradução de Carlo Alberto Dastoli. São Paulo, Martins Fontes, 2006,
} 
Sabemos o quanto esta definição está carregada de ideologia, mas isto não a torna inútil. Ao contrário, é próprio da ideologia "confessar" um aspecto da verdade. A falsidade está em exacerbar este aspecto de tal modo que os demais acabem ocultados ou obliterados. Verifica-se, assim, uma "ilusão/alusão ${ }^{84 ", ~ t e r m o ~ q u e ~}$ tomamos emprestado de Althusser, indicando que a operação ideológica obscurece a realidade e, ao mesmo tempo, a revela em parte ao se referir a ela. Neste marco, a proclamação burguesa de igualdade e liberdade, a título de ilustração, constitui uma alusão à realidade, pois se reporta às condições materiais da circulação mercantil. Contudo, simultânea e determinantemente, há uma ilusão: a liberdade e a igualdade do mercado não se confundem com a liberdade e igualdade humanas ${ }^{85}$.

Sucede o mesmo com o Estado de Direito e suas liberdades democráticas. Há algo de verdade na garantia dos direitos individuais e na barreira ao arbítrio estatal, e se faz necessário conhecer a origem destas características. Não há de ser a dignidade humana, pelas mesmas razões que ela está descartada para as declarações de direitos ${ }^{86}$. Zolo esboça uma resposta, e se por um lado não traz informações que estejam propriamente equivocadas, por outro não é capaz de introduzir satisfatoriamente uma causalidade histórica. Este autor nos diz que o Estado de Direito é uma figura jurídico-institucional "que resulta de um processo evolutivo secular que leva à afirmação, no interior das estruturas do Estado moderno europeu, de dois princípios fundamentais: o da 'difusão do poder' e o da 'diferenciação do poder'87". O primeiro seria a tendência de restrição dos poderes do

p. 11. A leitura crítica deste autor o coloca muito a frente dos juristas convencionais, mas não é o bastante para desmistificar completamente o Estado de Direito. Faltam-Ihe as ferramentas teóricas do marxismo. De resto, destacamos que trabalharemos com um conceito geral de Estado de direito, é dizer, com o que há de comum entre os modelos do Rechtsstaat, do rule of Law e do État de droit.

${ }_{84}$ "Portanto, admitindo que elas [as ideologias moral, jurídica, política etc.] não correspondem à realidade, admitimos que elas se referem à realidade e que basta 'interpretá-las para encontrar, sob a sua representação imaginária do mundo, a realidade mesma desse mundo (ideologia = ilusão/alusão)" (ALTHUSSER, Op. Cit., 2007, p. 86).

${ }^{85}$ Tanto isto é verdade que a ligação entre os direitos humanos e o mercado capitalista é admitida (alusão), embora em tom entusiástico (ilusão), por um Ludwig von Mises, este apóstolo do credo capitalista: "A liberdade, tal como dela desfrutaram as pessoas nas democracias da civilização ocidental na época em que prevalecia o velho liberalismo, não era o produto de constituições, declarações de direitos, leis ou regulamentos. Estes documentos visavam apenas a salvaguardar a liberdade, firmemente estabelecida pelo funcionamento do mercado, contra os abusos cometidos pelos detentores do poder. Nenhum governo e nenhuma lei civil podem garantir ou propiciar um clima de liberdade, a não ser pela defesa e sustentação das instituições fundamentais em que se baseia a economia de mercado" (MISES, Ludwig von. O mercado. Tradução de Donald Stewart Jr.. Rio de Janeiro: José Olympio, 1987, p. 67).

${ }^{86}$ Danilo Zolo não deixa esquecer que "a noção de 'Estado de Direito' conviveu longamente com a escravidão dos negros africanos e, depois, com a discriminação racial” (ZOLO, Op. Cit., 2006, p. 10).

${ }^{87}$ ZOLO, Op. Cit., 2006, p. 31. 
Estado para dilatar o âmbito das liberdades individuais, ao passo que o segundo seria a distinção do sistema jurídico-político com relação a outros sistemas, como o ético-religioso e o econômico.

Tudo isso é correto, mas bastante epifenomênico. Ao contemplarmos a materialidade das coisas, podemos enxergar melhor. Os dois princípios anunciados por Danilo Zolo explicam-se, primeiramente, pelos caracteres da dimensão repressiva do Estado capitalista à luz da forma jurídica. A autoridade coloca-se como pública, como um terceiro imparcial que legitimamente monopoliza a violência na comunidade. E ela só se coloca como pública porque se erige sobre um conjunto de indivíduos juridicamente iguais, todos portadores de direitos e consagrados como cidadãos. Num ambiente organizado em tais marcos, o emprego da força bruta não pode ocorrer da mesma forma que ocorre em comunidades formalmente hierarquizadas, organizadas pela escravatura, pela servidão ou por outra via política (diretamente coercitiva) de extração do produto social que sobeja.

Registramos ao final do capítulo anterior que, no capitalismo, processa-se uma separação do aparelho de coerção física em face da classe dominante, e que a exploração se consuma pela própria reprodução das relações de produção, sendo regida pela lei do valor, e não pelo império da força. Nesta ordem de considerações, as esferas econômica e jurídico-política estão claramente apartadas, uma jamais se confunde com a outra, ao contrário do feudalismo, em que o feudo é, a um só tempo, unidade política e econômica. A separação em comento, aliada ao fato de que o Estado burguês se edifica sobre cidadãos livres e iguais para permutar seus bens, permite que os princípios de difusão e diferenciação sejam assimilados em conformidade com a história.

Convém salientar, no entanto, que esses princípios não possuem peso igual na teoria do Estado de Direito. O princípio da difusão do poder, pela própria definição de Zolo, ocupa lugar de destaque. Os direitos e liberdades individuais, objeto de tutela do Estado de Direito, são sua razão de ser. Segundo o jurista que temos acompanhado, o controle do poder se expressa por meio dos seguintes instrumentos normativos ${ }^{88}$ : unicidade e individualidade do sujeito jurídico, igualdade jurídica dos sujeitos individuais e certeza do direito. A unicidade e individualidade

\footnotetext{
${ }^{88}$ Normativos na opinião de Zolo, evidentemente. Nossos pressupostos pasukanianos afastam a centralidade da norma. É a consumação massiva das trocas mercantis que engendra as normas que Ihe convém, e não o oposto. A Lex mercatoria adveio da prática mercantil, e não do Estado. Foi ela quem antecedeu e inspirou os códigos comerciais nacionais.
} 
referem-se à aptidão dos indivíduos para serem titulares de direitos e para lograrem conseqüências jurídicas com seu comportamento. A igualdade jurídica reporta-se ao igual tratamento perante a lei (instrumento legislativo de caráter geral), seja na subsunção normativa, seja na aplicação das consequências jurídicas. Por fim, a certeza do direito consiste em se garantir a cada cidadão "a capacidade de prever, em linha de princípio, as conseqüências jurídicas seja dos próprios comportamentos, seja dos atores sociais com os quais entra necessariamente em contato" ${ }^{89}$."

Excetuando-se esse último atributo "normativo" do Estado de Direito, acreditamos que os demais estão contemplados por tudo o que pontuamos até aqui. Quanto à certeza do direito, sua vinculação com as demandas do circuito mercantil não poderia ser mais cristalina. Obviamente, quem quer fazer circular suas mercadorias precisa de clareza sobre as regras do jogo. A previsibilidade e o cálculo são indispensáveis aos negócios. Em nosso entendimento, tão indispensáveis que se aplicam até mesmo à violência do Estado, que passa a ser calculável, ou melhor, mensurável.

Em verdade, a violência estatal deve ser calculável no Estado de Direito tanto pela forma jurídica quanto pela natureza da economia capitalista. Afinal, forma e conteúdo só se apartam analiticamente. Na economia capitalista, observa-se uma trajetória de racionalização das técnicas produtivas que caminha da manufatura à indústria concentrada, dos pequenos capitais aos monopólios, das incipientes aplicações produtivas do capital comercial às finanças de grande monta. $O$ imperativo econômico de valorização do capital impõe cada vez mais uma fragmentação do trabalho (bem como do trabalhador) pela especialização e pela mecanização, além de introduzir crescentemente as formas fetichizadas do capital financeiro. Lukács captou esta tendência e a traduziu num "princípio da racionalização baseada no cálculo, na possibilidade de cálculo90". A necessidade de prever, com efeito, não é privativa do comerciante que se arrisca na circulação. A indústria e as finanças estão igualmente atreladas a esta racionalidade. Não por acaso, o desenvolvimento do fordismo e, depois, da acumulação flexível (normalmente nomeada pela experiência principiada no Japão, a saber, o toyotismo)

\footnotetext{
${ }^{89}$ ZOLO, Op. Cit., 2006, p. 39.

${ }^{90}$ LUKÁCS, Georg. História e consciência de classe: estudos sobre a dialética marxista, 2. ${ }^{\text {a }}$ ed.. Tradução de Rodnei Nascimento. São Paulo: Martins Fontes, 2012, p. 202. Acrescenta ainda, na p. 207, que "o princípio da mecanização racional e da calculabilidade deve abarcar todos os aspectos da vida" no capitalismo.
} 
trouxe consigo novas alternativas de gerenciamento empresarial e de aproveitamento do setor de serviços, sempre com o intuito de maximizar lucros e cortar despesas. A exploração do trabalhador não é, como nos primórdios do capitalismo, um fator que se resume ao número de empregados e de horas labutadas. Tornou-se necessário que a exploração seja qualitativamente eficaz, não apenas quantitativamente. Pois bem, estas técnicas de administração empresarial que emergiram para dar novo ânimo à extração de mais-valia nos períodos de crise do capital também se prestam a tornar os empreendimentos econômicos mais previsíveis e calculáveis.

O capital exige que o mundo esteja preparado para dar cumprimento a seus caprichos e fantasias da melhor maneira. Consciente disto, empenha-se em moldálo ao talante de seus interesses, inclusive no tocante à violência de classe organizada, o Estado. Não basta o monopólio da violência pela autoridade estatal. Esta exclusividade proporciona certa margem de certeza, mas se o uso da força for arbitrário, a dificuldade continua. Tem-se, então, que se o comportamento dos indivíduos (os agentes de mercado de fato ou potenciais) precisa ser calculável por parâmetros objetivos, que independem de qualquer agente (recebendo, assim, a coroa legal), não convém que a violência aplicável sobre eles fuja à regra. Aliás, o que se espera é que nada escape a esta regra na sociedade capitalista.

Basicamente, a calculabilidade capitalista demanda burocracia e legalidade, e em se tratando do Estado, ambos estão interligados. A burocracia consiste, no Estado de Direito, não apenas num meio de afastar as massas da condução dos negócios públicos. O seu conjunto de procedimentos invariáveis permite que os atos da autoridade pública sejam calculáveis, o que traz segurança aos indivíduos, tanto na administração quanto na atividade jurisdicional, e o direito concorre diretamente para isso:

O direito (...) pode e deve operar como instrumento de ritualização do exercício do poder. Em outras palavras, é preciso que os poderes do Estado (antes de tudo o executivo e o judiciário) estejam vinculados ao respeito de regras gerais. A 'lei', como modalidade normativa 'geral e abstrata' (típicoabstraente), deve substituir a commissio, ou seja, o comando pessoal do monarca e suas arbitrárias e não motivadas lettres de cachet. $\mathrm{O}$ direito como 'lei' pode obter, por meio de imposição de formas e de procedimentos gerais - muito mais do que por meio da prescrição de conteúdos ou fins particulares -, uma drástica redução da discricionariedade política. Um poder obrigado a se expressar segundo regras gerais no interior de formas 
predeterminadas é, de fato, um poder mais transparente - ou menos opaco - e por isso mais 'visível' e controlável por parte dos cidadãos ${ }^{91}$.

A esta ritualização do uso do poder a que se presta a burocratização do Estado, une-se a legalidade no bojo da tarefa mais elementar do Estado na democracia liberal (a qual se materializa funcionalmente como Estado de Direito ${ }^{92}$ ). Franz Neumann colabora com esta percepção:

\begin{abstract}
A tarefa primordial do Estado é criar um Estado Legal que garanta a execução dos contratos, pois uma parte indispensável para o sucesso empresarial é saber com um certo grau de certeza que os contratos serão respeitados. Contudo, essa calculabilidade e previsibilidade, desde que os competidores sejam de fôrças aproximadamente iguais, só podem ser conseguidas por meio de leis gerais, leis essas que devem ser tão definidas em seus pontos abstratos que o mínimo possível seja deixado à descrição do juiz. Em uma sociedade dessa natureza, o juiz fica, portanto, proibido de recorrer à Generalklauseln. Sempre que o Estado interferir na disposição do indivíduo sôbre sua liberdade e propriedade, deverá fazer que isso seja calculável antecipadamente, e não poderá nunca fazê-lo de forma retroativa, pois isso frustraria tôdas as expectativas existentes. Também não pode intervir extralegalmente, porque isso seria outrossim imprevisível. Não poderá ainda intervir com medidas isoladas, porque tal intervenção violaria o princípio de igualdade dos competidores. Além de tudo, o juiz deve ser independente, e os litígios devem ser decididos sem levar em conta os desejos do Govêrno. É por isso que deve haver uma separação de podêres que, sem contar com o seu significado político, é da maior importância para a organização do sistema competitivo, uma vez que provê uma divisão de competências e fixa os limites entre as várias atividades do Estado, garantindo assim a racionalidade do direito e a sua aplicação ${ }^{93}$.
\end{abstract}

Em Zolo e Neumann, predomina uma análise normativista do fenômeno jurídico, o que não prejudica nosso estudo. A norma jurídica é parte importante do direito, mesmo não sendo central. Em adendo, a lei enquanto um comando abstrato e geral com o condão de tornar calculáveis as relações sociais e o poder político só existe num espaço habitado por sujeitos-cidadãos, por sujeitos de direito. E se o poder político, em particular, é calculável no capitalismo, ele o é não porque a lei o cria com tal configuração, e sim porque este poder se encontra envolto por expedientes burocráticos intrincados e por uma arquitetura institucional liberal, forjada pela legalidade e pela separação de poderes.

\footnotetext{
${ }^{91}$ ZOLO, Op. Cit., 2006, p. 36.

92 "O liberalismo é uma doutrina do Estado limitado tanto com respeito aos seus poderes quanto às suas funções. A noção corrente para representar o primeiro é Estado de direito; a noção corrente para representar o segundo é Estado mínimo" (BOBBIO, Norberto. Liberalismo e democracia, 6. ed.. Tradução de Marco Aurélio Nogueira. São Paulo: Brasiliense, 2005, p. 17).

${ }_{93}$ NEUMANN, Franz. Estado democrático e Estado autoritário. Tradução de Luiz Corção. Rio de Janeiro: Zahar, 1969, p. 50.
} 
Expliquemo-nos. Os atributos da lei moderna (generalidade e abstração) são determinados pelo modo como vivem seus destinatários, que são os indivíduos formalmente livres e iguais do mercado capitalista (cidadãos, do ponto de vista político). A vida nestas circunstâncias exige uma crescente burocratização das instâncias empresariais e estatais para que as expectativas de comportamento sejam calculáveis, favorecendo o fluxo dos negócios. Acrescenta-se a isto uma legalidade que reforça a previsibilidade do aparato institucional do Estado, estabelecendo mecanismos de contenção do poder. Aí entra a separação dos poderes e suas conseqüências (judiciário independente, mandatos parlamentares, controle do executivo etc.), bem como a legalidade e suas conseqüências (irretroatividade, adstrição às formas legais, judiciário vinculado à lei etc.)

Especificamente no tocante à legalidade, indispensável a observação de Alysson Mascaro:

\begin{abstract}
A legalidade só se torna plena no capitalismo, e nele sua lógica ganha autonomia e se reproduz. A vitória de um governo de leis, não de homens, e a vitória do mecanismo institucional sobre a vontade do soberano só se tornam possíveis a partir do momento em que a lógica econômica é de auto-reprodução. O capitalismo enseja a ascensão de um modelo de instâncias sociais que subverte as bases das antigas manifestações político-jurídicas. O lugar do político, anteriormente o lugar do arbítrio pleno, da vontade sem peias, vai abrindo espaço para o controle, para a regulamentação, para os limites. O absolutismo talvez tenha sido a última expressão de um mundo político não plenamente adequado à autoreprodução econômica e seu conseqüente regime de plena legalidade ${ }^{94}$.
\end{abstract}

Há duas lições a se aprender de toda esta descrição dos atributos do Estado de Direito: (i) a lei não produz os direitos civis e políticos, sendo antes determinada pelas mesmas circunstâncias econômicas que determinam esses direitos, e com a função de Ihes tutelar; (ii) no Estado de Direito, a força bruta é empregada sob mediação da forma jurídica, perfazendo um direito público, o que é muito particular ao capitalismo e à democracia liberal. Esmiucemos as implicações desta última lição, de modo a encontrarmos o fecho de nosso esquema teórico sobre o assunto.

\footnotetext{
${ }^{94}$ MASCARO, Alysson Leandro. Crítica da legalidade e do direito brasileiro. São Paulo: Quartier Latin, 2003, p. 22. Sendo certo ainda que, com a legalidade, vem a impessoalidade, também em nítida oposição à estrutura feudal do Estado absolutista. Complementa o jurista pátrio: "A impessoalidade passa então a ser a marca aparente da legalidade, ao lado do pressuposto da igualdade formal e da liberdade nos limites da lei. Sua trajetória ideológica quer ser bem clara: rompe com o privilégio, rompe com o senhorio, estabiliza a instância política a tal ponto que ela é a administração política e não a fundação da política - a democracia moderna capitalista é formal e essencialmente representativa, como mera administração nos limites possíveis do direito - e completa a auto-reprodução econômica capitalista" (p. 36).
} 
A violência cometida pelo Estado na democracia burguesa ou liberal afigurase como uma limitação ou tolhimento de liberdades e direitos. Para cometê-la legitimamente, isto é, para limitar ou tolher liberdades e direitos em conformidade com os pressupostos da democracia liberal, o Estado deve obedecer a trâmites burocráticos determinados e a formas estipuladas em lei ${ }^{95}$. Nisto consiste a essência das liberdades democráticas sob o liberalismo: o direito de ser agredido pela autoridade de modo calculável e "racional". A violência organizada e concentrada da classe dominante é a mesma, só muda o método de utilização.

O Estado de Direito pode coagir os cidadãos tanto pelo poder de polícia quanto pelo Poder Judiciário. De um modo ou de outro, a forma jurídica marca presença. As medidas administrativas que coagem os cidadãos, que interferem na sua esfera individual de direitos, estão conformadas pela burocracia e pelos procedimentos. Qualquer limitação a direitos civis e políticos, principalmente aos de liberdade (no uso de força policial em tumultos, controle de fronteiras, fiscalizações em geral etc.), e de propriedade (na cobrança de tributos, tombamento, desapropriação etc.), em tese, só pode se dar nos termos calculáveis que temos apresentado. E no caso de excesso, de uso abusivo e desmedido da coerção, o Estado pode ser submetido à jurisdição ${ }^{96}$.

Em outras ocasiões, a violência estatal só é tolerada pelo filtro do Judiciário ${ }^{97}$. A supressão concreta, para um indivíduo, do desfrute de seus direitos é condicionada por um mandado de prisão ou de busca e apreensão, expedido por um juízo competente que permita o desenvolvimento de uma lide. O direito processual

\footnotetext{
95 "Dizendo que o Estado é obrigado pelo direito, pretende-se dizer, em primeiro lugar, que o Estado legislador é obrigado pelo direito a fazer certas leis e a não fazer outras. Pretende-se dizer, em seguida, que o Estado, depois de fazer uma lei, e enquanto essa lei subsistir, é obrigado pela própria lei que fez: pode modificá-la, revogá-la até, mas enquanto ela existir é obrigado a obedecer a essa lei tanto como os seus súditos; os seus funcionários administrativos, os seus juízes e os seus legisladores devem aplicar a lei e só podem agir nos limites que ela estabelece. E este o regime da legalidade" (DIGUIT, Léon. Fundamentos do direito. Tradução de Eduardo Salgueiro. Porto Alegre: Sergio Antonio Fabris Editor, 2005, p. 53).

96 "O Estado, em virtude da própria idéia, é o justificável dos seus próprios tribunais. Pode ser parte num processo, pode ser condenado pelos seus próprios juízes e é tido como um simples particular quando executa a sentença pronunciada contra si próprio" (DIGUIT, Op. Cit., 2005, p. 55).

${ }^{97}$ Karl Liebknecht referiu-se ao Judiciário afirmando que, nele, "o Estado eleva-se, em certo sentido, para além de si mesmo". Sua posição é a seguinte: "O Poder Judiciário constitui a função mais sublime do Estado, porque o próprio Estado - e, na verdade, também seu Poder Legislativo submete-se a esse Poder, criado por ele mesmo. Pelo menos, isso deve ser assim. Nos Estados Unidos da América, uma lei, declarada sem validade pela Suprema Corte Judiciária, é considerada, simplesmente, como eliminada. O juiz situa-se, em certa dimensão, acima do próprio Estado" (LIEBKNECHT, Karl. Acerca da Justiça de Classe. Tradução de Emil von München. São Paulo: Instituto José Luís e Rosa Sundermann, 2002, p. 23).
} 
penal é um ótimo exemplo em que esta lógica é levada ao paroxismo. No processo penal, o Estado é cindido em personalidades distintas: Poder Judiciário e Ministério Público, por exemplo. O primeiro personifica o Estado-juiz, o poder público encarregado de apreciar os conflitos entre os átomos da sociedade, ao passo que o segundo personifica a própria sociedade, que demanda contra um indivíduo acusado de atentar contra ela.

Ora, quando se tem uma situação em que o Estado precisa ajuizar uma ação para atacar o direito de um indivíduo, uma situação em que, dizendo de outro modo, a autoridade se converte em sujeito de direito para satisfazer um interesse seu (preservar a ordem), não resta dúvida que a forma jurídica se apoderou do uso da força, que esta forma não é o antagonismo da violência, mas antes o critério para a sua utilização precisa em cada caso concreto. O mesmo vale ao se pôr o Estado no polo passivo de uma ação: a oposição ao poder estatal é, com efeito, uma faculdade do cidadão. Uma pessoa comum pode processar um órgão estatal, encará-lo frente a frente perante os tribunais, equipada com todo o arsenal que o devido processo legal lhe tem a oferecer (caso haja reais possibilidades de acesso à Justiça).

Se olharmos para configurações políticas diversas, notaremos que nelas 0 Estado agride seus súditos sem utilizar o direito, aplicando a força sem qualquer cerimônia ou critério de medida. Nos regimes absolutistas, o monarca mandava e desmandava sem qualquer contenção legal ou burocrática, sua vontade era lei. $\mathrm{O}$ manuseio do poder nestas circunstâncias, ou em condições análogas, exclui a forma jurídica. Retornemos a Pasukanis:

Não é difícil provar que a idéia de submissão incondicional a uma
autoridade normativa externa não possui a mínima relação com a forma
jurídica. É suficiente tomarmos os exemplos limites que, devido a isto, são
mais claros. Peguemos uma formação militar, na qual muitos homens são
subordinados, em seus movimentos, a uma ordem comum, na qual o
princípio ativo e autônomo é a vontade do comandante. Ou, ainda, o
exemplo da Ordem dos Jesuítas na qual todos os irmãos da comunidade
executam, cegamente e sem discussão, a vontade do superior. Basta que
se aprofunde estes exemplos para se concluir que quanto mais o princípio
da regulamentação autoritária, que exclui toda referência a uma vontade
autônoma particular, seja aplicado de maneira conseqüente, tanto mais se
restringe o campo de aplicação da categoria direitog8.

O poder inconteste e desmedido da autoridade, portanto, não dá espaço para que a face política do sujeito de direito (a cidadania) se desenvolva. Resta apenas a

\footnotetext{
${ }^{98}$ PASUKANIS, Op. Cit., 1989, p. 73.
} 
face privada, imediatamente conectada à circulação de mercadorias, e que independe do Estado. Nos exemplos da Ordem dos Jesuítas e da formação militar, claramente inexiste um direito público, pois a independência individual de seus participantes, em termos políticos, é esmagada por uma hierarquia absoluta. Não há átomos, apenas engrenagens desprovidas de autonomia formal no interior de um aparelho. Para que não haja dúvidas, é suficiente compararmos a posição em que se encontra o acusado numa corte das Forças Armadas e numa corte civil. É, nesta, e não naquela, que a forma jurídica preside os procedimentos.

Para reiterar esta tese, será interessante analisar brevemente o avesso do Estado de Direito. Quando a democracia burguesa desmorona por obra das classes dominantes, cedendo lugar a um regime autoritário ou totalitário instaurado via Estado de exceção, a cidadania é negada em nome da manutenção da ordem. A natureza repressiva do Estado é liberada, dando-se vazão a toda a violência que lhe é constitutiva.

O Estado de exceção é um cenário político de indeterminação, onde o direito público pereceu e as classes estão em guerra aberta e declarada. Todos os filtros, todos os meios de represamento do embate político assumem um papel secundário, não decisivo. O desfecho do confronto não depende da orientação dos tribunais ou da correlação de forças nos governos e parlamentos. Autores como Giorgio Agamben entendem que, nesta hipótese, a ordem jurídica soçobra como um todo. Afirma ele que "o estado de exceção não é um direito especial (como o direito da guerra), mas, enquanto suspensão da própria ordem jurídica, define seu patamar ou seu conceito-limite ${ }^{99, "}$. Decerto que o filósofo exagera, e seu erro foi ter se enveredado pelo neokantismo. Para ele, investigar o Estado de exceção significa adentrar uma "terra de ninguém", uma zona cinzenta "entre o direito público e o fato político e entre a ordem jurídica e a vida ${ }^{100 " . ~ L i g e i r a m e n t e ~ c a m u f l a d a ~ e m ~ p a l a v r a s ~}$ elegantes, eis aí a separação neokantiana entre ser e dever-ser, tão celebrada por Kelsen, e na qual se acha a já mencionada confissão involuntária do normativismo e do positivismo jurídico sobre sua impotência científica. Este abismo entre a forma jurídica e o mundo real imaginado pelos positivistas, além de ser falso, desloca o

${ }^{99}$ AGAMBEN, Giorgio. Estado de exceção, 2. ${ }^{a}$ ed.. Tradução de Iraci D. Poleti. São Paulo: Boitempo, 2007, p. 15. Para este autor, suspende-se a ordem jurídica para garantir-lhe a existência e o regresso num momento favorável.

${ }^{100}$ AGAMBEN, Op. Cit., 2007, p. 12. 
debate do seu eixo correto, que é a natureza do Estado, no tocante a sua faceta repressiva, enquanto terror organizado.

Mais feliz foi a escolha de Nicos Poulantzas pelo método marxista. Mesmo que Poulantzas não disserte sobre o direito com a mesma desenvoltura e correção que Pasukanis, o pensador radicado na França não se ocupa de uma zona misteriosa de indeterminação entre o direito e o mundo vivente. As considerações que tece sobre o que acontece com o direito no Estado de exceção são as seguintes:

O direito, digamo-lo sucintamente, já não regula nada: é o arbitrário que reina. $O$ que caracteriza o Estado de exceção não é tanto o transgredir as suas regras, mas o fato de nem sequer estabelecer as suas próprias 'regras' de funcionamento: no sentido, entre outros, de um sistema, quer dizer, de um conjunto que preveja - e que permita prever - as suas próprias transformações ${ }^{101}$.

Nesta passagem, Poulantzas ilumina a primazia do arbitrário nas ações do Estado, demonstrando que, para sobreviver, ou apenas para não fazer uma concessão comprometedora, a classe capitalista está disposta a abrir mão da preciosa calculabilidade do comportamento estatal. Mas ela só abre mão em parte, e seria um engano pensar que a ordem jurídica como um todo é afastada. Prossegue o autor um pouco depois:

Pode mesmo dizer-se que o Estado de exceção em geral deixa, no essencial, intacto esse aspecto do direito que regulamenta os fundamentos econômicos do sistema capitalista, nele fazendo apenas, eventualmente, as simples modificações exigidas pelo estágio no interior do qual se situa. Para tomar um outro exemplo ilustre, também Luís Bonaparte não fizera mais que conservar e desenvolver o Código Civil $^{102}$.

O direito privado, desta forma, é conservado em meio às intempéries que levam ao afastamento do direito público. O que fica no lugar deste último é a violência desmedida e incalculável. Se no Estado de Direito a força bruta é utilizada em doses moderadas e determináveis, o regime de exceção não se orienta por uma dosagem, fazendo o que for necessário para a conservação da ordem. E mesmo

\footnotetext{
101 POULANTZAS, Nicos. Fascismo e ditadura. Tradução de João G. P. Quintela e M. Fernanda S. Granado. São Paulo: Martins Fontes, 1978, p. 344. Recordemos que as razões são políticas, como consta na página seguinte: "Esta ausência de limites, juridicamente fixados, liga-se assim ao mesmo tempo ao 'jogo' particular de intervenção do Estado de exceção face à instabilidade hegemônica, e ao acréscimo do seu papel de repressão sobre as massas populares".

${ }^{102}$ POULANTZAS, Op. Cit., 1978, p. 346.
} 
que os instrumentos coercitivos do Estado de exceção estejam constitucionalmente previstos (o estado de sítio, a lei marcial, os poderes de emergência etc.), a sua utilização é sempre obscura, amiúde por normas secretas. Ora, sendo desmedida e altamente verticalizada, a violência do Estado burguês, nas condições em tela, anula ou inibe a cidadania não só para os indivíduos (isto é, ataca direitos civis e políticos sem os quais o capitalismo pode passar), como também para as classes como um todo. A burguesia abre mão do exercício do poder pelo parlamento, enfraquecendo seu poder político em nome de seu poder social ${ }^{103}$. Ameaçado por uma crise política aguda, o burguês é inteiramente capaz de desacorrentar uma fera que, apesar de indomável, faz o serviço sujo, e a explicação para este fenômeno está na teoria dos aparelhos de Estado.

Salientemos nos escritos de Poulantzas o seguinte excerto:

É verdade que a forma de Estado de exceção é marcada por um
recrudescimento característico da repressão física organizada. Todavia,
pela reorganização global do Estado, o que importa aqui é a nova relação
entre o aparelho repressivo e os aparelhos ideológicos. No quadro desta
relação, a dominância de uma ou dos outros especifica formas de regimes
do Estado de exceção. Com efeito, esta dominância, consoante a relação
de forças e a distribuição do poder de classe no seio do sistema estatal,
pode ser detida: a) pelo próprio aparelho repressivo de Estado e um dos
seus ramos - o exército no caso das ditaduras militares, a administração
civil no caso dos bonapartismos, a política no caso do fascismo
estabelecido; b) por um aparelho ideológico de Estado: por exemplo, o
partido durante o primeiro período do fascismo no poder, ou a lgreja no
caso de ditaduras 'clericais militares' como a de Dollfus na Áustria

Não pretendemos de modo algum avançar em pormenores nas modalidades de Estado de exceção ${ }^{105}$. Interessam-nos na citação apenas dois apontamentos: (i) o rearranjo da forma de emprego da brutalidade estatal é tratada pelo teórico como uma reorganização global do Estado, na medida em que necessariamente implica uma nova relação entre os aparelhos repressivos e os aparelhos ideológicos; (ii) a exacerbação de um aparelho frente aos demais torna-o dominante, e é em torno

\footnotetext{
${ }^{103}$ Analisando o Estado de exceção na França no texto O 18 Brumário de Luís Bonaparte, Marx nota um momento em que "o burguês privado só pode continuar a explorar outras classes e a gozar pacificamente da propriedade, da família, da religião e da ordem com a condição de a sua classe ser condenada com as outras classes à mesma nulidade política" (MARX, Karl. A revolução antes da revolução. Tradução de José Barata-Moura e Eduardo Chitas. São Paulo: Expressão Popular, 2008, pp. 263-264).

${ }_{104}$ POULANTZAS, Op. Cit., 1978, pp. 340-341.

${ }^{105}$ Restringir-nos-emos a citar a obra em que Gilberto Bercovici aborda, dentre outros tantos temas, o estado de exceção, problematizando a concentração de poder estatal na esfera do Executivo, sobretudo nos EUA. Vale conferir: BERCOVICI, Gilberto. Soberania e constituição: para uma crítica do constitucionalismo. São Paulo: Quartier Latin, 2008.
} 
dele que o Estado organizará a dominação de classe ${ }^{106}$. No Estado de exceção, haverá de ser um aparelho predominantemente repressivo, cujo agir resulta na condenação dos indivíduos e das classes à nulidade política mencionada por Marx.

Felizmente para os capitalistas, a monopolização do poder estatal pelo exército ou pela administração civil está longe de ser um fardo insuportável. O clima para os negócios nestas circunstâncias pode não ser 0 melhor, mas é indubitavelmente mais reconfortante para a burguesia que um governo caia por uma articulação no interior do Estado do que por uma insurreição popular. E não importa quem estiver à frente, seja exército ou administração civil: o Estado continua sendo burguês, continua prestando-se ao serviço de conservação e garantia das relações de produção. A história dos países periféricos patrulhados pelo imperialismo estadunidense nos convence de que as burguesias nacionais não são nada criteriosas nas suas preferências políticas. Contentam-se com qualquer governo que contenha as lutas populares, ainda que ele seja instaurado e amparado por providência estrangeira. Os capitalistas, de fato, só cogitam a ideia de tirania se sua propriedade privada estiver sob alguma ameaça.

Com todas as ponderações que apresentamos até agora, damos por demonstrado que os direitos humanos de primeira dimensão, estes componentes elementares da democracia burguesa que são guarnecidos pelo Estado de Direito quando a luta de classes assim o tolera, são a medida da truculência estatal no uso de suas atribuições repressivas, o que nada tem que ver com a abstração da dignidade humana ${ }^{107}$.

Fizemos um contraste entre o Estado de Direito e o Estado de exceção para ilustrar a tese de que os direitos civis e políticos, não obstante tenham suas raízes na produção e na circulação capitalistas, podem ser afastados por interesses igualmente capitalistas, incorporados na razão preservativa de Estado. No próximo item, ocupar-nos-emos de dar continuidade a este raciocínio partindo da democracia propriamente, e não da sua negação. E partiremos da democracia no instante do

\footnotetext{
${ }^{106}$ Poulantzas aduz, em obra diversa, que "se tal ou qual aparelho detém o papel dominante no seio do Estado (partidos políticos, parlamento, executivo, administração, exército), não é apenas porque ele concentre o poder da fração hegemônica, mas porque ele consegue da mesma maneira, e ao mesmo tempo, cristalizar a função político-ideológica do Estado diante das classes dominadas" (POULANTZAS, Op. Cit., 2000, pp. 144-145).

107 "A verdadeira diferença entre democracia e ditadura consiste primeiro na ausência de limites no poder político da ditadura, em contraste com as restrições voluntárias que a democracia se impõe. É ùnicamente essa a significação do domínio dos direitos do homem" (NEUMANN, Op. Cit., 1969, p. 295).
} 
conflito, quando suas tensões internas são elevadas exponencialmente e seus limites são postos à prova.

\subsection{Um exemplo prático: o espaço dos conflitos sociais na democracia liberal}

O regime democrático-liberal espera que os conflitos da comunidade sejam travados conforme seus parâmetros institucionais. A luta legítima pelos rumos políticos possíveis da sociedade é aquela que preferencialmente se processa pelo aparato institucional do Estado (disputa eleitoral do parlamento) ou, quando muito, por ações exteriores ao âmbito estatal, sem que, contudo, contrarie-se o disposto pela legalidade (manifestações "pacíficas", "compatíveis com a democracia”).

Tudo orbita em torno da imagem da lei, este demiurgo da legitimidade democrática. Se quisermos entender o real papel da norma estatal positivada na ideologia burguesa liberal, basta iniciar as averiguações pelas declarações de direitos. A Declaração dos Direitos e Deveres do Homem e do Cidadão da constituição francesa de 1795, fruto imediato do Termidor imposto pela alta burguesia, dispõe:

Art. 5. Ninguém é homem de bem, se não observa sincera e religiosamente as leis.

Art. 6. Aquele que viola abertamente as leis declara-se sem estado de guerra contra a sociedade.

Art. 7. Aquele que, sem infringir abertamente as leis, as elude com astúcia ou destreza, fere os interesses de todos: ele se torna indigno da benevolência e da estima geral.

Onde estará a dignidade humana agora? O homem, supostamente o centro da ordem jurídica, seu senhor e destinatário, pode ser condenado ao status de pária social num átimo. É suficiente que não observe os comandos do Estado burguês para que deixe de ser "homem de bem" e se torne "indigno da benevolência e da estima geral".

A legalidade é, pois, o paradigma de bom senso, caráter e civilidade da sociedade burguesa. Quem Ihe faz apologia automaticamente homenageia a mentalidade burguesa ${ }^{108}$. Ludwig von Mises nos confirma, propondo que a coerção

108 "O elogio da legalidade é o elogio de um mundo cuja lógica faz com que a exploração seja relegada aos porões da vida social. (...) A lei garante um mundo cuja transação é formalizada pela aparência de equivalência social, e, ao sacralizar a igualdade legal, guarda nos porões escondidos da sociedade aquilo que o altar das leis não vê: a injustiça real, a coerção econômica, a desigualdade 
pelas normas do Estado não faz mais do que deter indivíduos dotados de "malignidade, imediatismo ou inferioridade mental ${ }^{109 ", ~ e ~ q u e ~ s o m e n t e ~ e s t a s ~ s u p o s t a s ~}$ feras têm razões para temer o tacão de ferro do Estado ${ }^{110}$.

Pela teoria liberal, a legalidade merece ser inviolável por emanar de uma esfera de representação popular. Argumenta-se em adendo que a dignidade humana permanece presente na sua imperatividade por conta de que a execução forçada da lei, isto é, o ato repressivo, obedece a ritos que se propõem a preservar a integridade da pessoa. Principiemos por este segundo argumento. Não há dúvida de que o uso da força pela administração e pela Justiça, no contexto normal da democracia burguesa, é um marco progressista da civilização. As espoliações abençoadas com a marca da coroa e os "julgamentos" promovidos pela Inquisição são episódios obscuros dos quais a humanidade pode ter orgulho de tê-los superado. Não obstante, a emergência de alternativas superiores não se fundamenta na graça do gênero humano. Confira-se o advento do direito penal. A irracionalidade dos juízos de Deus e a arbitrariedade dos magistrados do Absolutismo foram trocadas pelas orientações liberais do Estado de Direito, que beneficiam os indivíduos não só pela calculabilidade das decisões judiciais, mas também pelos princípios atinentes às penas. Não se admite que a pena passe da pessoa do condenado, nem os castigos físicos e o tratamento degradante no cárcere. Todos estes direitos, assim como os outros que compõem o rol de garantias do réu, são consagrados como fundamentais em vários tratados que abarcam direitos humanos de primeira dimensão e na maioria das constituições. E mais: a monopolização do ius puniendi por uma autoridade constituída legalmente afasta o caráter de vingança privada da pena de épocas anteriores.

Substituindo a vingança privada, o direito penal consiste num critério de vingança pública, numa medida da repressão estatal no exercício de suas atribuições punitivas. O emprego da força bruta, aqui, é calculável em detalhes.

que se mantém e a brutal diferença que o sistema social mantém e agrava" (MASCARO, Op. Cit., 2003, p. 23).

109 "O que se consegue através do aparato social de compulsão e coerção é o impedimento da ação de indivíduos cuja malignidade, imediatismo ou inferioridade mental impossibilitam a compreensão de que, ao praticarem atos lesivos à sociedade, estão prejudicando a si mesmos e a todos os outros seres humanos" (MISES, Op. Cit., 1987, p. 61).

110 "Na sociedade de mercado, a compulsão direta e a coerção só podem ser empregadas para prevenir atos prejudiciais à cooperação social. No mais, a polícia não interfere na vida dos cidadãos. Quem respeita as leis não precisa temer carcereiros e verdugos. A pressão necessária para o esforço conjunto de produção é exercida pela estrutura de preços de mercado" (MISES, Op. Cit., 1987, p. 72). 
Cada crime tem sua pena prevista, cada pena tem sua extensão estabelecida, cada circunstância qualificadora ou diminuidora, agravante ou atenuante, tem seu peso estipulado. Quanto mais intensa for a violência do Estado de Direito contra o indivíduo, tanto mais mensurável ela deve ser.

Este avanço costuma ser um inebriante canto de sereia para seus observadores. Eles olvidam que se a violência quantificável é ainda violência, a vingança pública é ainda vingança. Podemos dizer que o encarceramento de um indivíduo por uma quantidade de tempo legalmente prevista é algo mais "digno" (ou menos degradante) que as penas corporais da Idade Média. Só não se pode inferir disto que a dignidade humana conduziu a este desfecho ou motivou as transformações históricas. Filósofos como um Beccaria podem estar imbuídos de uma nobre e sincera compaixão pelos homens, mas este sentimento não é capaz de forjar novas leis ou de fomentar novos regimes.

Ao nos nortearmos pelo materialismo histórico, fica claro que estas mudanças se explicam por uma base material. A aplicação de penas, bem se sabe, é evento ordinário nas mais diversas épocas e nas mais diversas civilizações, passando por regimes políticos os mais diferentes. A democracia burguesa, como vimos, notabiliza-se pelo uso mensurável da brutalidade, sob mediação da forma jurídica. Ao condenado, no Estado de Direito, é dado receber a medida exata de repressão a que fez jus, o que se expressa no quantum de liberdade que perderá. A pena, nesta configuração jurídica, é a quantidade de violência, sempre calculada por critérios legais, que o Estado desfere contra o indivíduo, correspondendo à lesão que ele tenha causado à coletividade. Esta violência é proporcional ao crime cometido, ou melhor, é equivalente a ele. Trata-se da imposição, pelo Judiciário, de uma purgação ao sujeito de direito que corresponda, de algum modo, ao dano perpetrado pelo infrator. Visualizaremos melhor com uma disposição do Código Penal brasileiro em vigor: de acordo com o artigo 121 deste diploma legal, o ato de matar alguém, abstraindo-se quaisquer vetores favoráveis ou desfavoráveis, exige que o agente purgue de seis a vinte anos de reclusão. A operação é análoga à troca mercantil ${ }^{111}$ : há um sinalagma, um critério de equivalência, entre a conduta delituosa e a penalidade.

\footnotetext{
111 "O delito pode ser considerado como uma variedade particular de circulação, na qual a relação de troca, a relação contratual, é fixada pela ação arbitrária de uma das partes. A proporção entre delito e reparação igualmente se reduz a uma proporção de troca" (PASUKANIS, Op. Cit., 1989, p. 146)
} 
Os liberais, jubilosos de sua civilização burguesa (ou os pensadores que partilham da mesma metodologia), hão de nos atirar à face que as penas ditas aviltantes, ou cruéis, são proibidas, e que o encarceramento é, em contraste com elas, um ato de dignidade e de bonomia, não de vingança. De começo, precisariam convencer-nos de que as prisões carecem de vileza e crueldade, mas não é esta a explicação que devemos thes cobrar. Se Ihes perguntarmos por que somente na aurora da modernidade capitalista a privação quantificada da liberdade alçou-se ao patamar de penalidade predominante, por certo que nos lembrariam de que este instante histórico "coincide" com a eclosão das primeiras ideias iluministas. Estas ideias, por sua vez, só poderiam proceder da evolução do espírito humano ou de algo que exprima uma concepção semelhante. Pasukanis, ao contrário, procura a resposta na produção da riqueza social:

\begin{abstract}
Para que a idéia de possibilidade de reparar o delito com a privação de um quantum de liberdade pudesse nascer, foi necessário que todas as formas concretas de riqueza social estivessem reduzidas à forma mais abstrata e simples - o trabalho humano medido em tempo. Indubitavelmente, estamos diante de um exemplo de interação entre os diversos aspectos da cultura. $O$ capitalismo industrial, a Declaração dos Direitos do Homem, a economia política de Ricardo e o sistema de detenção temporária são fenômenos que pertencem a uma mesma época histórica ${ }^{112}$.
\end{abstract}

Quando a lei do valor impera no reino da reprodução social, o trabalho humano abstrato, que se mede apenas pelo tempo ${ }^{113}$, impõe a sua dinâmica ao modo de produção, inclusive na instância jurídica e nas instituições penais. Lembremos que a existência de um mecanismo de proporcionalidade nas penas é bastante anterior ao capitalismo (encontramo-lo na Lei de Talião do mundo antigo), e o mesmo vale para a figura do cárcere. É somente na sociedade capitalista, todavia, que se espraia a equivalência entre as condutas criminosas e a repressão penal, e foi somente nela que a prisão se elevou ao status de ser o castigo em si, já que antes ela era apenas o local onde o condenado aguardava sua punição.

Agora, lancemo-nos ao argumento liberal acerca da representatividade popular pelo parlamento. Esta posição, para autores como Bobbio e afins, ganhou

\footnotetext{
${ }^{112}$ PASUKANIS, Op. Cit., 1989, p. 159.

113 "Não é preciso dizer, pois, que uma hora de um homem vale uma hora de outro homem, mas sim que um homem de uma hora vale um outro homem de uma hora. O tempo é tudo, o homem não é mais nada; ele é no máximo a carcaça do tempo" (MARX, Karl. Miséria da Filosofia: Resposta à Filosofia da Miséria de Proudhon, 2ª . ed.. Tradução de Torrieri Guimarães. São Paulo: Martin Claret, 2007, p. 85).
} 
força com o advento do sufrágio universal. As leis produzidas pelas casas parlamentares, a partir de então, representariam finalmente a todos, não apenas as classes possuidoras. Em oportunidade anterior, opusemos a esta leitura o caráter capitalista da forma jurídica no tocante ao sujeito-cidadão, indicando que a cidadania política envolvia uma estrutura de exploração e dominação. É chegado o momento de dar prosseguimento à crítica, desta vez com enfoque nas determinações que atuam sobre o Estado burguês.

Qualquer Estado, enquanto tutor das relações de produção numa sociedade dividida em classes, desempenha um duplo papel. Conservar um modo de produção não implica apenas conformar os segmentos dominados na inércia, mas também organizar a dominação das classes proprietárias (o que envolve ainda as relações entre as frações dessas classes) e a administração dos negócios comuns que lhes concernem $^{114}$. No Estado burguês, em condições de normalidade (leia-se: democracia burguesa), tais atividade encontram no parlamento uma sede para a sua consumação e legitimação. Anotemos a contribuição de Mészáros a respeito:

\begin{abstract}
Em parte, o papel regulador essencial do Parlamento consiste em legitimar (e, desse modo, também 'internalizar') a imposição das severas regras da 'legalidade constitucional' sobre o trabalho potencialmente recalcitrante. Mas o papel do Parlamento não está, de modo algum, limitado a isso. No seu desenvolvimento histórico, sujeitar o trabalho à autolegitimação da 'legalidade constitucional' ficou em segundo plano em relação à sua função crucial, original e primeira, que consistiu e consiste em permitir à pluralidade de capitais encontrar, em todos os momentos do desdobramento da dinâmica do sistema, o necessário (mesmo que sempre temporário) modus vivendi e o equilíbrio de poder entre seus componentes. É assim que o capital social total pode afirmar suas regras na esfera política sob as condições da 'democracia parlamentar' ${ }^{\text {'115 }}$.
\end{abstract}

As referidas funções de legitimação da violência e de composição política entre os capitais, apesar de sediadas e chanceladas no parlamento, não são determinadas nesta instância. $O$ processo de arquitetura da política e das decisões

\footnotetext{
114 "Em relação principalmente às classes dominantes, em particular a burguesia, o Estado tem um papel principal de organização. Ele representa e organiza a ou as classes dominantes, em suma representa, organiza o interesse político a longo prazo do bloco no poder, composto de várias frações de classe burguesas (pois a burguesia é dividida em frações de classe), do qual participam em certas circunstâncias as classes dominantes provenientes de outros modos de produção, presentes na formação social capitalista: caso clássico, ainda hoje em dia, nos países dominados e dependentes, dos grandes proprietários de terra. Organização, na perspectiva do Estado, da unidade conflitual da aliança de poder e do equilíbrio instável dos compromissos entre seus componentes, o que se faz sob a hegemonia e direção, nesse bloco, de uma de suas classes ou frações, a classe ou fração hegemônica" (POULANTZAS, Op. Cit., 2000, pp. 128-129).

${ }_{115}$ MÉSZÁROS, István. Para além do capital: rumo a uma teoria da transição. Tradução de Paulo Cezar Castanheira e Sérgio Lessa. São Paulo: Boitempo, 2009, pp. 838-839.
} 
sobre o poder como um todo é exterior à esfera institucional, pois o capital é uma força extraparlamentar por excelência"116, que decide nos "bastidores" e depois encaminha seus imperativos econômicos para a chancela formal. Os mandatários da nação nas casas parlamentares não são mais do que correias de transmissão da burguesia para que seus desígnios sejam atendidos, e a possibilidade de candidaturas operárias levou não à perda do caráter burguês da democracia liberal, e sim a uma multiplicação de lobbies e a práticas de cooptação de lideranças dos trabalhadores.

O conteúdo dos projetos de lei (ou até a redação do projeto ${ }^{117}$ ) é decidido pelas empresas que contratam os prepostos do povo, sendo que a esta contratação chama-se financiamento de campanha. Nas eleições de 2010 no Brasil, os partidos da ordem, desde os ditos de "esquerda" (PT, PC do B etc.), passando pelos de "centro" (PMDB, PV etc.) e chegando aos de "direita" (PSDB, DEM etc.), foram agraciados por $\mathrm{R} \$ 99$ milhões das empreiteiras, $\mathrm{R} \$ 50$ milhões da agroindústria, $R \$$ 29 milhões das empresas de mineração, metalurgia e siderurgia e $R \$ 13$ milhões dos bancos ${ }^{118}$. Estas informações, aliás, não só reiteram a natureza burguesa do parlamento, como também anunciam um salto qualitativo nos seus serviços ao capital. A necessidade de mais segurança nos negócios, por conta dos volumes enormes de capitais aplicados a partir da era imperialista, aliada à importância cada vez maior da intervenção estatal no mercado (criação de infra-estrutura, fiscalização, fomento de demanda etc.), leva as empresas a se apoiarem ainda mais no Estado. O seleto grupo dos capitalistas monopolistas adquire como vantagem uma centralização de capital tamanha que lhe permite, em contraste com os concorrentes, ter acesso privilegiado a este nicho de mercado que se tornou o parlamento burguês, uma inegável plataforma de investimentos do clube dos poderosos. Com isso, aumenta a previsibilidade das políticas do Executivo e da

116 "O capital não é em si uma força parlamentar, apesar de seus interesses poderem ser adequadamente representados no Parlamento, como mencionamos antes. O que necessária e antecipadamente decide contra o trabalho no confronto político com o capital, confinado ao Parlamento, é o inescapável fato de que o capital social total não pode deixar de ser uma força extraparlamentar par excellence" (MÉSZÁROS, Op. Cit., 2009, p. 851).

117 Em 2010, Cândido Vaccarezza, deputado federal (PT/SP), apresentou um PL redigido por uma advogada ligada à Monsanto, notória multinacional do agronegócio, com o objetivo de legalizar o uso das sementes "Terminator". Este exemplo certamente é apenas uma gota no oceano.

${ }^{118}$ NAVARRO, Sílvio; COSTA, Breno. Construtoras ajudam a eleger $54 \%$ dos novos congressistas.

Folha de São Paulo, São Paulo, 07 nov. 2010. Disponível em $<$ http://www1.folha.uol.com.br/poder/826575-construtoras-ajudam-a-eleger-54-dos-novos-Congressistas.shtml>. Acesso em: 07 fev. 2010. 
orientação do Legislativo para os capitais privilegiados, e na exata medida em que ambas são encomendadas.

E é neste confortável balcão de altos negócios, em meio a estas transações nas quais os capitalistas apostam cifras milionárias, que o reformismo pretende, candidamente, lograr leis e medidas da administração capazes de emancipar os trabalhadores. Carlos Nelson Coutinho, entusiasmado com a "sociedade civil articulada e pluralista" que surgia na última fase do regime militar brasileiro, vislumbrava um futuro cor-de-rosa no qual uma democracia de massas se desenvolveria no Brasil e acabaria por renovar o parlamento, ao qual recairia o "papel insubstituível" de ser um "instrumento unitário que corporifique (...) a progressiva hegemonia das classes trabalhadoras na vida política brasileira ${ }^{119, "}$. Inequivocamente, a história não foi nada favorável a este agouro: o que as "contribuições" de campanha (em verdade, investimentos) nos mostram é o banquete capitalista naquele nicho de mercado.

Estendendo seus vaticínios para além das fronteiras nacionais, Coutinho imaginou que esta tendência valeria para todo o mundo capitalista. Segundo ele, a socialização da produção impulsionada pela indústria possibilitou o surgimento de sujeitos coletivos na política (associações operárias e profissionais, partidos de massa etc.), o que tiraria de cena o individualismo liberal. Haveria, então, uma socialização objetiva da participação política que "implica tendencialmente a passagem de uma democracia liberal clássica para uma democracia de massas ${ }^{120 " . ~}$ Esta democracia de massas seria, na tradição reformista (que tem em Togliatti seu principal expoente do século XX, com a defesa de uma "democracia progressiva"), um locus de conflito pautado pelas regras do jogo consensuais e um espaço que serviria como uma superestrutura de transição para uma sociedade socialista. A chave para o sucesso deste modelo seria uma engenhosa "articulação entre organismos populares de democracia de base e os mecanismos tradicionais de representação indireta (como os parlamentos) ${ }^{121 " .}$

\footnotetext{
${ }^{119}$ COUTINHO, Carlos Nelson. A democracia como valor universal: notas sobre a questão democrática no Brasil. São Paulo: Livraria Editora Ciências Humanas, 1980, p. 39.

${ }_{120}$ COUTINHO, Op. Cit., 1980, p. 27. Para o autor, a existência de sujeitos coletivos é em si transformadora, pois em nenhum instante ele se preocupa com o sentido da atuação destas entidades. A integração ao Estado não o incomoda, como se isto não estivesse no cerne do peleguismo sindical e da capitulação dos partidos operários.

${ }^{121}$ COUTINHO, Op. Cit., 1980, p. 28. Este autor assumiu a dianteira do reformismo nacional. No ano de 1980, em que Coutinho já maltratava o marxismo com suas elaborações revisionistas, a CUT e o PT ainda se orientavam pelo classismo, um conjunto de princípios políticos abertamente hostis a
} 
As previsões de Coutinho confirmaram-se parcialmente. Com efeito, houve uma articulação entre organismos populares e a esfera de representação indireta (tanto os parlamentos como o Poder Executivo). Não se pode negar que foi costurada uma harmoniosa relação política entre os condutores do Estado, os dirigentes oficiais da classe trabalhadora e a classe patronal: a social-democracia foi uma peça-chave na reprodução do capital no período do Welfare State na Europa, e ainda hoje, no Brasil, o princípio da "concertação social" é o norte da política. O erro foi supor que a emancipação social viesse por esse caminho. $O$ que se viu foi o oposto, porque ao Estado de bem-estar social (e às suas variantes mais "tímidas") sucedeu o neoliberalismo, e não o socialismo. E a reviravolta neoliberal ${ }^{122}$ foi engendrada e encomendada no bojo da "democracia de massas", sendo por ela igualmente executada. No paraíso democrático inefável pintado por Coutinho e seus afins, as burocracias sindicais celebram acordos indignos (sem prejuízo de seus privilégios e de suas rendas de fundo de pensão, naturalmente) e os trabalhadores são atacados por contrarreformas neoliberais vindas de coalizões encabeçadas pelo trabalhismo. Políticas neste sentido são feitas com o suporte da social-democracia e do sindicalismo conciliador e pelego, e nunca apesar deles ou contra eles.

Eis o que acontece quando se nutrem ilusões colossais sobre a natureza do Estado burguês e de seus aparelhos. Nem o sufrágio universal (Bobbio) e nem o relacionamento com organismos populares (Coutinho) impediram que os interesses da burguesia e os ataques contra os trabalhadores se realizassem pela via parlamentar. Ao contrário, o maior intercâmbio do parlamento com a classe trabalhadora, por mais que seja preferível à exclusão da cidadania, só fez legitimar a dominação burguesa. Os reformistas não percebem que eles próprios são importantes agentes de perpetuação do capital e de seu domínio. Ao incentivarem o movimento operário a se ajustar ao universo burguês, como se pudesse transitar impunemente por ele, como se pudesse jogar as regras do jogo sem capitular a elas, como se pudesse expulsar o inimigo de seu próprio campo, ou the submeter à sua "hegemonia", o tiro saiu pela culatra. Foram os "intrusos" que foram hegemonizados, que passaram a copiar as práticas e os discursos daqueles que, agora, não mais são seus adversários.

qualquer forma colaboração de classe e a qualquer tática que abale a independência dos trabalhadores e a confiança em suas próprias forças.

${ }_{122}$ As razões econômicas desta reviravolta serão explanadas no próximo capítulo. 
Uma vez que "o feitiço voltou-se contra o feiticeiro", o resultado não poderia ser outro: o trabalhismo reformista deixa de ser identificável com o trabalho, apesar de não perder sua influência sobre incontáveis setores obreiros (sendo esta a sua importância estratégica para o capital). Mészáros indica como óbvia a constatação de que a história do trabalhismo reformista "se caracteriza por sua integração progressiva à estrutura de comando político do capital e pela sua completa desintegração, por meio de sua ação capituladora mesmo como reformismo ${ }^{123}$."

O fato é que nem todos os reformistas revisam abertamente o marxismo. Não raro alguns reconhecem que o Estado é efetivamente um instrumento de dominação, e por isso dizem que a institucionalidade (em particular o parlamento) seria, para eles, apenas um dos muitos espaços de combate político, e sequer o mais importante - não seria mais do que a continuidade de uma luta essencialmente extraparlamentar no âmbito parlamentar. Se isso fosse verdade, não tomariam os ataques à classe trabalhadora desferidos pelos candidatos que ajudam a eleger como concessões necessárias e inexoráveis ao capital ou como um pequeno inconveniente da disputa por hegemonia (este emplasto que justifica qualquer barbaridade), e sim como atos de traição, como atos de lealdade à burguesia em detrimento dos trabalhadores. Sua postura se notabilizaria pela crítica ferrenha e pela apresentação de ultimatos às autoridades, e não por exigências midiáticas teatrais ou por manifestos pusilânimes.

Confirmando-se a natureza burguesa da democracia liberal e de suas instituições, logo se concebe os limites objetivos em que se inscreve o conjunto dos direitos políticos. Com os direitos civis não é diferente. Alguém poderia afirmar de boa-fé que, se por um lado as instituições de Estado estão sob o controle dos lobbies capitalistas, por outro este domínio não se daria, ou ao menos não ocorreria de modo tão agudo, no universo externo à institucionalidade, ou seja, na "sociedade

${ }^{123}$ MÉSZÁROS, Op. Cit., 2009, pp. 844-845. Processo análogo é observável com o Partido dos Trabalhadores no Brasil: "O PT se desfigurou ao ponto de ter mudado sua natureza de classe. Depois de quase uma década à frente do governo não deve continuar sendo considerado um partido operário independente ou reformista. Há muitos anos, o PT dos anos 1980 deixou de existir, mesmo mantendo o mesmo nome e, essencialmente, a mesma direção. Na verdade, desde meados dos anos 1990, pela via dos financiamentos eleitorais milionários, o PT deixou de ser uma expressão orgânica do movimento operário. O cordão umbilical que o unia no nascimento ao movimento operário deixou de existir" (ARCARY, Valério. Um reformismo quase sem reformas: uma crítica marxista do governo Lula em defesa da revolução brasileira. São Paulo: Instituto José Luís e Rosa Sundermann, 2011, p. 15). Mais adiante (p. 60), Arcary refere-se ao Partido dos Trabalhadores como a "máquina eleitoral mais profissional do Brasil", sendo, por isso, "integrada às instituições do regime e associada, estreitamente, a alguns dos mais poderosos grupos empresariais". 
civil. Nesta perspectiva, os conflitos encontrariam no domínio dos direitos civis uma área de livre trânsito e livre desenvolvimento. Contra esta suposição militam inúmeros fatores, a começar pela mera existência de aparelhos de Estado que transcendem o arcabouço repressivo. No mais, a regulação dos direitos civis é condicionada pelos imperativos burgueses da forma e da tutela jurídica, o que é da mais alta relevância.

Vejamos. Em seu "O 18 Brumário de Luís Bonaparte", Marx menciona a constitucionalização de direitos civis na França após a revolução de 1848, percebendo que estes direitos (liberdade pessoal, de imprensa, de palavra, de associação, de reunião, de ensino, de culto etc.) são limitados formalmente pelos direitos iguais dos outros e pela chamada segurança pública. Temos aí a estrutura elementar de qualquer carta política de uma democracia liberal ${ }^{124}$, em que cada parágrafo da constituição "contém em si, com efeito, a sua própria antítese, a sua própria câmara alta e câmara baixa: no fraseado geral, a liberdade; na glosa marginal, a supressão da liberdade ${ }^{125 ", . ~ A s ~ l i b e r d a d e s ~ p u ́ b l i c a s ~ s a ̃ o ~ e n t r a v a d a s ~ p o r ~}$ questões de ordem jurídica, e não apenas por contingências de ordem material e concreta (como o terrorismo policial nas periferias pauperizadas e as conversões de indivíduos a determinados credos por necessidade de socorro).

Aliás, estas liberdades são tão restritas que poderiam perfeitamente ser anunciadas pelo seu avesso sem qualquer prejuízo do conteúdo. Seria altamente concebível (embora politicamente inconveniente) redigir uma norma constitucional democrática que estabelecesse, por exemplo, que "são proibidas as reuniões em áreas públicas, ainda que pacíficas, a não ser que haja prévio aviso à autoridade competente". Evidentemente, a questão não se limita a um jogo de palavras. O que ocorre é a convivência conjugal entre a liberdade e sua negação no mesmo regime e, por que não, nas mesmas disposições normativas.

Pois o que serviria para dois proprietários avizinhados, impedidos de interferir na esfera privada do outro, serve para a política. Os direitos civis, espelhados no individualismo do mercado, prescrevem os contornos em que a ação política é tolerável ${ }^{126}$. A apreciação pelo Estado (o único ente com legitimidade para julgar

\footnotetext{
${ }^{124}$ A Constituição Federal brasileira de 1988 faz coro a este modelo, dispondo que reuniões pacíficas em áreas públicas são admitidas, desde que com prévio aviso à autoridade competente (art. 5., XVI). ${ }^{125}$ MARX, A revolução antes da revolução. Op. Cit., 2008.

126 "Os direitos e garantias fundamentais do homem e do cidadão positivados pelo Estado contemporâneo - a liberdade contratual, a igualdade formal, a propriedade privada e a segurança das
} 
numa comunidade de iguais) da linha que separa o chamado exercício regular de um direito do uso abusivo deste direito caracteriza a mais importante limitação que a democracia liberal impõe sobre a luta de classes, já que se trata de uma limitação oficialmente reconhecida e até mesmo enaltecida pela ideologia jurídica da burguesia.

Em regra, o direito abstrai as condutas, nivelando os atos de perturbação da ordem ou de interferências nas esferas privadas individuais. $O$ tratamento que a lei $e$ a administração têm para com um ato político que paralisa uma avenida não é diferente do tratamento para com um ato de arruaça qualquer. Abstraindo as razões, ao Estado pouco se importa se uma avenida foi paralisada por professores em passeata por ajustes salariais ou por torcedores de futebol em fúria. A repressão estatal ocupa-se apenas de eliminar o distúrbio sem discriminar suas intenções (eis a que serve o igualitarismo do direito), garantindo o direito fundamental de ir e vir dos transeuntes a caminho da exploração diária.

Isto que ora apontamos como um obstáculo insuperável à ação política na democracia liberal, diga-se logo, não incomoda em nada os juristas, nem mesmo a sua vanguarda pós-positivista, para quem tudo se soluciona no caso concreto com um cotejo de princípios. Os arautos do pós-positivismo hão de bradar que cabe à ordem jurídica preservar os direitos fundamentais em conflito, e que a melhor sorte de um ou de outro depende de cada lide. Esta fraseologia é elegante pelo tom de razoabilidade e eloqüência, mas não ajuda a luta dos trabalhadores. Se seus direitos estão constantemente tolhidos por outros direitos, sejam eles de indivíduos indeterminados (como os transeuntes) ou da sociedade em geral, então sua liberdade no agir político será sempre parcial, mutilada. Pode-se fazer passeata, com a condição de que seja uma "meia passeata", uma mobilização que não obstrua por completo o tráfego. Os trabalhadores podem cruzar os braços, desde que avisem o empregador com antecedência, que não ocupem o local de trabalho etc. Os servidores públicos podem entrar em greve, mas apenas se for uma "greve pela metade", garantindo um mínimo de serviço. Em todos estes cenários, o cotejo de princípios, a pretexto de não suprimir inteiramente nenhum direito fundamental, corrobora a mutilação da política de classe, a sua submissão à previsibilidade e às rédeas curtas do Estado, que atua em nome da democracia e do bem comum. 
Ousar ir além desta política recortada significa abusar de um direito, o que configura uma ilicitude ${ }^{127}$.

Chegamos, enfim, na luta de classes e nas suas derivações dentro dos marcos democráticos. No item anterior, consideramos o predomínio dos direitos civis e políticos (democracia liberal) como um período possível e conveniente no conflito entre as classes, passível de suspensão (na forma de estado de exceção), em contraste com as mais diversas teorias, inclusive algumas autoproclamadas marxistas, que enxergam na democracia uma conquista definitiva, um caminho sem volta. Pretendemos comprovar agora que mesmo nos marcos da normalidade institucional e do Estado de Direito, há ocasiões em que o tacão de ferro do Estado seja entregue ao arbítrio e à bestialidade. Esta é a última lição sobre a democracia burguesa que nossos reformistas teimam em não aprender, e é com ela que fecharemos o capítulo.

Transcrevamos, de início, algumas observações de Florestan Fernandes:

\begin{abstract}
Do micro ao macro, a sociedade capitalista contém toda uma rede de relações autoritárias, normalmente incorporadas às instituições, estruturas, ideologias e processos sociais, e potencialmente aptas a oscilar em função de alterações do contexto (ou, mesmo, de conjunturas adversas), tendendo a exacerbar-se como uma forma de autodefesa dos interesses econômicos, sociais e políticos das classes possuidoras e dominantes (ao nível institucional ou ao nível global). (...) A autodefesa cria um enrijecimento inevitável, nasça ela dos riscos de uma greve geral, das ameaças do movimento operário ou da viabilidade de uma revolução socialista. Automaticamente, os requisitos do contrato, do consenso e da representação sofrem um debilitamento, que se traduz por uma exacerbação das formas de dominação burguesa. O componente autoritário oscila, as relações autoritárias ganham saliência e a democracia fica um privilégio dos mais iguais (ou das elites no poder) ${ }^{128}$.
\end{abstract}

Como se vê, a luta de classes pode desencadear impulsos autoritários do interior da democracia liberal, sem que o Estado de Direito efetivamente degenere

\footnotetext{
${ }^{127}$ A proposição mais "radical" atingida pelo pensamento burguês sobre o tema está em Dworkin: "Se tenho o direito de expressar minhas idéias sobre questões políticas, o governo erra ao considerar ilegal que eu assim proceda, mesmo que pense que sua ação é no interesse geral. Se, além disso, o governo torna meu ato ilegal, comete um novo erro ao acionar a lei contra mim. Meu direito contra o governo significa que é um erro da parte do governo impedir-me de falar" (DWORKIN, Ronald. Levando os direitos a sério, 2. ${ }^{a}$ ed.. Tradução de Nelson Boeira. São Paulo: Martins Fontes, 2007, p. 295). Note-se que a solução encontrada adveio de um aprofundamento do individualismo, e não de sua superação. E nem poderia ser de outra forma quando se lida com átomos isolados, alheios a determinações de classe.

${ }_{128}$ FERNANDES, Florestan. Apontamentos sobre a "Teoria do Autoritarismo". São Paulo: Hucitec, 1979, pp. 13-14. A análise do autor lhe permite concluir o Estado de exceção "brota" do Estado democrático, e está embutido nele, revelando tendências autoritárias recônditas aos olhares não-dialéticos.
} 
em Estado de exceção. O recrudescimento das relações autoritárias que moldam a sociedade capitalista (lembremos do último item do capítulo precedente, quando citamos Ruy Fausto e sua concepção de que a violência do Estado "reflete" a violência do capital) torna a democracia um "privilégio dos mais iguais". Adaptando este entendimento para a tese que temos advogado, o uso da violência estatal, normalmente adstrito a formas burocráticas calculáveis, torna-se arbitrário, aclarando o despotismo de classe. Os direitos civis não são revogados, mas são neutralizados em casos concretos, quer dizer, para cada atitude de insubordinação das organizações das classes dominadas, que ficam isoladas por um cordão de inconstitucionalidade que circunscreve uma zona em que "vale tudo" na repressão.

llustremos com o que ocorre no Brasil, com sua democracia festejada internacionalmente. A repressão a movimentos sociais é expediente corriqueiro em terras brasileiras, e ela se dá pelo caminho liberal-democrático (acionar o Judiciário) e por caminhos alternativos, da autotutela violenta a telefonemas noturnos para comandantes de polícia eventualmente pertencentes ao círculo de amizades de quem faz a denúncia. Todavia, assistiu-se em 2008 a um salto qualitativo nas atividades de cerceamento da política. No Rio Grande do Sul, o Ministério Público, em parceria com a Brigada Militar, moveu uma cruzada contra o MST, pretendendo extinguir o movimento por motivos como: (i) escolas que fariam "lavagem cerebral nos alunos"; (ii) bibliotecas contendo livros "agressivos" de autores que insuflariam uma "estratégia confrontacional" (Che Guevara, Paulo Freire, Chico Mendes, Florestan Fernandes e outros); (iii) uma "fraseologia agressiva, abertamente inspirada nos slogans dos países do antigo bloco soviético ('pátria livre, operária, camponesa')". Onde estarão as liberdades de expressão e de associação, os direitos fundamentais? Os promotores, por certo, diriam que estão postas na Constituição para defender os cidadãos de bem e a democracia, e não para acobertar crimes dos inimigos do Estado. E antecipando a indagação que fizemos, trataram logo de ressuscitar a Lei de Segurança Nacional da ditadura militar, colocando-a, desta vez, como linha de defesa da democracia! E tudo isso para lançar o movimento dos trabalhadores sem-terra numa "terra de ninguém", numa zona especial sem liberdades públicas, onde a cidadania é reduzida, quando muito, à cruel dosimetria do Código Penal.

Não é preciso ser especialista em direito constitucional para compreender a incompatibilidade entre estas justificativas invocadas pelas autoridades do Rio 
Grande do Sul na perseguição ao MST e as liberdades democráticas anunciadas no artigo 5. da Constituição Federal. Trouxemos a lume esta experiência por ser ela a mais manifesta, caricata mesmo. Nas incontáveis demais, a argumentação das autoridades não é tão grosseira, e a repressão aos movimentos sociais causa pouca ou nenhuma estranheza no meio jurídico.

O caso em tela também ilustra que o Estado capitalista, ainda que em regime democrático, não necessariamente observa a legalidade por ele instaurada. Nicos Poulantzas corretamente vê neste fenômeno uma razão de Estado, um impulso de preservação do status quo que não se atém aos parâmetros estabelecidos quando eles não dão conta de sua tarefa. Observa-se, então, a negação do Estado de Direito no interior dele mesmo, isto é, sem que ele ceda lugar a um estado de exceção. O regime liberal fica intacto, agindo contra os agentes insubordinados (ou contra as comunidades sem voz nas favelas) como se não fosse regime liberal. A condição de classe das vítimas da democracia burguesa garante a esta o luxo de não atuar como democracia burguesa contra elas. A razão de Estado não é nada mais do que esta "vida dupla" do Estado burguês, "que significa que a legalidade é compensada por 'apêndices' de ilegalidade ${ }^{129,}$, e que o Estado se organiza para funcionar segundo a lei e contra lei, uma vez que as classes dominantes atuam segundo a lei ou contra a lei conforme melhor lhes aprouver ${ }^{130}$. Neste sentido, 0 Estado é sempre uma ditadura de classe, pois se compromete a conservar as relações de produção a qualquer custo, e a democracia está longe da fazer com que - Estado burguês fuja a esta lógica. Pelo contrário, ele persiste como "ordem funcional única de legalidade e de ilegalidade, de uma legalidade vazada por ilegalidade ${ }^{131 "}$.

Elucida-se, com isso, o enigma das várias violações pelo Estado dos direitos civis e da legislação que os afirma, ainda que em geral prevaleça a utilização calculável da força. Uma teoria revisionista, empolgada com os direitos humanos,

\footnotetext{
${ }^{129}$ POULANTZAS, Op. Cit., 2000, p. 82. Esta razão de Estado aparece como uma situação em que a política "pode deixar de lado a moral e o direito para agir em consideração do bem do Estado, de acordo com a necessidade política" (BERCOVICI, Op. Cit., 2008, p. 48).

${ }^{130} \mathrm{O}$ uso tático da legalidade, tipicamente defendido pelo bolchevismo, causa horror aos reformistas, amantes que são das "instituições democráticas", como se elas fossem um fim em si mesmas. Mal sabem eles que o uso da legalidade também é tático para a burguesia, com a diferença que ela, enquanto classe dominante, conta com chances infinitamente maiores de impunidade (vide o massacre de Eldorado dos Carajás em 1996 e tantas outras ocorrências em que as elites cometem crimes atrozes e nada lhes acontece).

${ }^{131}$ POULANTZAS, Op. Cit., 2000, p. 83.
} 
acaba sendo obrigada a tratar estes acontecimentos como meramente acidentais, quando na verdade eles são demonstrações certeiras do que realmente vem a ser o Estado burguês, ou uma discreta amostra do que ele tem a oferecer em situações de crise política.

Não obstante, não há dúvidas de que, para a classe trabalhadora, a democracia burguesa interessa mais do que a ditadura. Colocando em outras palavras, a primeira é preferível à segunda, o que não lhe abona e nem lhe redime perante a história e perante as necessidades de emancipação dos trabalhadores. Lênin nos adverte, com seu espírito de síntese usual, que "uma forma de opressão e de luta de classes mais ampla, mais livre, mais franca, facilitará enormemente ao proletariado a sua luta pela abolição das classes em geral ${ }^{132 ” . ~ A ~ n a ̃ o ~ s e r ~ u m ~}$ ambiente menos sufocante, nada há que se esperar do domínio dos direitos humanos de primeira dimensão.

${ }^{132}$ LENIN, Vladimir llitch. O Estado e a revolução: o que ensina o marxismo sobre o Estado e o papel do proletariado na revolução. Tradução revista por Aristides Lobo. São Paulo: Expressão Popular, 2007, p. 96. 


\section{O MODO DE PRODUÇÃO CAPITALISTA E OS DIREITOS HUMANOS SOCIAIS}

Todas as disposições tomadas pelo Estado capitalista, mesmo as impostas pelas massas populares, são finalmente e a longo prazo inseridas numa estratégia em favor do capital ou compatível com sua reprodução ampliada ${ }^{133}$.

Nicos Poulantzas

Agora que a primeira dimensão dos direitos humanos já foi objeto de uma análise crítica, resta fazer o mesmo com a segunda. E do mesmo modo que foi feito no capítulo anterior, traçaremos um panorama histórico para contextualizar os direitos sociais. Ao fazê-lo, não nos focaremos, como é a praxe, no constitucionalismo social (tendo na Constituição de Weimar de 1919 seu maior marco), e sim no Welfare State (sua ascensão e queda), por ter sido o modelo mais acabado de sistema de direitos sociais que o capitalismo já conheceu.

Posteriormente, passaremos ao exame dos direitos sociais numa perspectiva pasukaniana. Utilizaremos as categorias da forma jurídica (sujeito de direito, relação jurídica e Estado - aqui como "Estado-juiz" ou "Estado providência") neste campo para, em seguida, estudar as determinações econômicas e políticas de seu conteúdo. Contemplaremos, assim, as necessidades de reprodução da mão-de-obra no mecanismo de acumulação e as influências da luta de classes neste processo.

Esta investigação nos conduzirá ao enfrentamento do caráter contraditório dos direitos sociais. Ao se constatar que o capitalismo afirma estes direitos (não pode passar sem eles, e é somente nas sociedades capitalistas que eles existem), e ao mesmo tempo os nega (o neoliberalismo, principal instrumento de ataque aos direitos sociais, não é mais do que a vazão das tendências do capital), é preciso definir como esta contradição se resolve no plano prático. Haveremos de averiguar se tais direitos são anticapitalistas, como afirmam autores como Fábio Konder Comparato, ou se neles predomina o caráter conservador do sistema que os engendra, mesmo que este mesmo sistema se ocupe constantemente de atacá-los. Citaremos o direito do trabalho como referência de estudo, considerando que nele a luta de classes está imediatamente colocada.

\subsection{A maturidade do capitalismo}

${ }^{133}$ POULANTZAS, Op. Cit., 2000, p. 188. 
Nossa narrativa sobre o capitalismo no capítulo anterior havia se dado até meados do século XIX, com a entrada em cena do proletariado enquanto agente político. O principal impulsionador deste evento foi o avanço da indústria capitalista, ou seja, a conquista do mundo pelo capital industrial. Marx e Engels narram este acontecimento nos anais da literatura política mundial de forma memorável:

\begin{abstract}
Pressionada pela necessidade de mercados sempre mais extensos para seus produtos, a burguesia conquista a terra inteira. Tem que imiscuir-se em toda a parte, instalar-se em toda a parte, criar relações em toda parte.

Pela exploração do mercado mundial, a burguesia tornou cosmopolita a produção e o consumo de todos os países. Para grande pesar dos reacionários, retirou da indústria sua base nacional. As antigas indústrias nacionais foram aniquiladas e ainda continuam a ser nos dias de hoje. São suplantadas por novas indústrias cuja introdução se torna uma questão de vida ou morte para todas as nações civilizadas: essas indústrias não empregam mais matérias-primas locais, mas matérias-primas provenientes das mais longínquas regiões, e seus produtos acabados não são mais consumidos somente in loco, mas em todas as partes do mundo, ao mesmo tempo. (...) A auto-suficiência e o isolamento regional e nacional de outrora deram lugar a um intercâmbio generalizado, a uma interdependência geral entre as nações ${ }^{134}$.
\end{abstract}

E para além de estabelecer um intercâmbio inédito entre os povos, ainda que calcado na exploração, o capitalismo acelerou, naquela época, o progresso das forças produtivas em escala extraordinária, como nenhum outro modo de produção existente poderia acelerar. O século XIX conheceu inovações formidáveis no domínio humano sobre a natureza, como o maquinismo, a aplicação da química à indústria e à agricultura, a navegação a vapor, as ferrovias, o telégrafo e os primeiros usos da eletricidade.

A concretização de todas essas maravilhas e de muitas outras, mesmo atualmente, perfaz-se à custa de exploração e alienação humanas ${ }^{135}$, e demanda centralização de capital. O último quarto do século XIX presenciou esta concentração de modo muito intenso, levando Lênin a propor uma periodização da história dos monopólios nestes moldes ${ }^{136}$ : i) anos 1860-1880: ponto culminante do desenvolvimento da livre concorrência. Os monopólios não passam de embriões

\footnotetext{
${ }^{134}$ MARX; ENGELS, Manifesto do partido comunista. Op. Cit., 2006, pp. 29-30.

135 Sob o capitalismo, "o trabalho produz maravilhas para os ricos, mas produz privação para o trabalhador. Produz palácios, mas cavernas para o trabalhador. Produz beleza, mas deformação para o trabalhador. Substitui o trabalho por máquinas, mas lança uma parte dos trabalhadores de volta a um trabalho bárbaro e faz da outra parte máquinas. Produz espírito, mas produz imbecilidade, cretinismo para o trabalhador" (MARX, Karl. Manuscritos econômico-filosóficos. Tradução de Jesus Ranieri. São Paulo: Boitempo, 2009, p. 82).

${ }_{136}$ Conferir em LÊNIN, Vladimir llich. O imperialismo: fase superior do capitalismo, 4. ${ }^{\text {a ed. }}$ Tradução de Olinto Beckerman. São Paulo: Global, 1987.
} 
pouco perceptíveis; ii) após a crise de 1873: grande desenvolvimento dos cartéis, embora apenas em caráter excepcional e sem estabilidade; iii) expansão do fim do século XIX e crise de 1900-1903: os cartéis tornam-se uma das bases da vida econômica, e o capitalismo "transforma-se" em imperialismo, quer dizer, assume esta faceta em definitivo. Inaugura-se então uma época em que é possível inventariar os recursos do planeta e partilhá-los de acordo com os interesses dos monopólios mais poderosos, fato que, em princípio, pressupunha também uma partilha territorial do planeta ${ }^{137}$.

Note-se que, na época do livre-cambismo, a burguesia enxergava nas colônias apenas uma excrescência do mercantilismo, até mesmo um fardo fiscal. Com o monopolismo, isto mudou. A importância do colonialismo foi revigorada aos olhos daqueles que, desde então, buscavam espaços para aplicar seus capitais excedentes. No mais, era preciso ainda alocar o "excedente da população" para evitar "guerras civis". Numa palavra, controle da luta de classes.

Aliás, a luta de classes é central para o entendimento do período. A aguda crise econômica de 1857 e a guerra civil nos EUA, que abalou a indústria têxtil inglesa ao prejudicar as exportações de algodão, fomentaram uma situação exasperadora para a classe operária europeia. Em 1864, surgia como resposta a I Internacional, embora esta organização, apesar de suas importantes intervenções, só ganhou projeção com o apoio oferecido à Comuna de Paris, em 1871.

O advento da Comuna, que apresentou os rudimentos da forma política em que se poderia dar a ditadura do proletariado, ensejou um incisivo contra-ataque das classes dominantes, e não apenas na esfera política, com as perseguições às correntes mais radicais. A notável prosperidade econômica posterior aos espasmos de crise, imediatamente associada à monopolização imperialista dos capitais, permitiu conquistas nas áreas trabalhista e previdenciária, principalmente na Alemanha, que veio a se tornar o epicentro do movimento operário internacional até o início do século XX.

E foi na Alemanha, então, que se consolidou o principal bastião da classe trabalhadora: a II Internacional. Organizando a classe trabalhadora em partidos

\footnotetext{
137 "Se os capitalistas partilham o mundo, tal sucede não em virtude de sua particular maldade, mas porque o grau de concentração já atingido os obriga a comprometerem-se nesta via a fim de obterem lucros; e partilham-no 'proporcionalmente' aos capitais, 'segundo as forças de cada um', porque, em regime de produção mercantil e de capitalismo, não poderia existir qualquer outro modo de partilha" (LÊNIN, Op. Cit., 1987, p. 74).
} 
políticos, esta entidade foi decisiva também por ter divulgado o marxismo e por ter encampado, antes de sua falência e degeneração, a defesa do fim do capitalismo. $O$ instante mais ilustrativo de sua sucumbência foi a capitulação ao chauvinismo na votação favorável aos créditos de guerra. A ala radical de Rosa Luxemburgo e Karl Liebkecht havia sido derrotada pela ala conservadora encabeçada por Bernstein, e com isso a estratégia de uma revolução proletária contra as classes capitalistas de todo o mundo havia naufragado. Prevaleceu a aliança com as burguesias nacionais e a aquiescência com a distribuição limitada de riquezas extorquidas nos domínios coloniais, alimentando uma aristocracia operária que se colocou como suporte da estratégia reformista ${ }^{138}$.

Ainda neste capítulo veremos de modo mais aprofundado as relações entre reprodução econômica capitalista, luta de classes e direitos sociais. Por enquanto, basta indicar a contradição: por um lado, os trabalhadores enfrentaram seus patrões e obtiveram, não raro à custa de sangue, melhorias consideráveis em suas condições de vida e de trabalho; por outro, estas mesmas melhorias eram indispensáveis para o movimento econômico, tanto para viabilizar a manutenção da oferta de mão-de-obra disciplinada (resignada com o sistema econômico) como para ampliar minimamente os horizontes da circulação mercantil, sem falar na necessária formação de exércitos para os combates interimperialistas que estavam por vir. 0 regime monopolista conduz a rivalidades entre as nações imperialistas, e importa dizer que se trata de um desdobramento do modo capitalista de produção, como explicou Lênin:

A Inglaterra, uma vez tornada capitalista, e tendo adotado o livre-câmbio, por volta dos meados do séc. XIX, pretendeu desempenhar o papel de 'oficina do mundo inteiro', de fornecedora de artigos manufaturados de todos os países que deviam, em troca, abastecê-la de matérias-primas. Porém, a Inglaterra, a partir do último quartel deste século, começou a perder este monopólio. Outros países, que se haviam defendido graças a direitos alfandegários 'protetores' tornaram-se, por seu turno, Estados capitalistas independentes. No limiar do séc. XX, assistiu-se à constituição de um outro gênero de monopólios: primeiro, associações monopolistas em todos os países de capitalismo evoluído; em seguida, a situação de monopólio de alguns países muito ricos, onde a acumulação de capitais

138 "Os grandes lucros extraídos da exploração dos países coloniais e semicoloniais permitiram às grandes potências dar algumas migalhas a seus trabalhadores. Esses trabalhadores privilegiados constituíram a aristocracia operária, que foi a base social de fortes burocracias políticas e sindicais" (SAGRA, Alicia. A Internacional: um permanente combate contra o oportunismo e o sectarismo, 2.. ed.. Tradução de Paula Maffei. São Paulo: Instituto José Luís e Rosa Sundermann, 2010, p. 29). A autora acrescenta que o fracasso da insurreição russa em 1905 desmoralizou a ala revolucionária da II Internacional. 
atingia enormes proporcões. Nos países avançados formou-se um enorme 'excedente de capitais' ${ }^{139}$.

Os excedentes de capitais demandavam colônias para escoamento lucrativo, e as guerras vieram remediar a "desproporção entre, por um lado, o desenvolvimento das forças produtivas e a acumulação de capitais e, por outro lado, a partilha das colônias e das 'zonas de influência' do capital financeiro ${ }^{140, . ~ E m ~ 1912, ~}$ para exemplificar, a Alemanha produzia 17,6 milhões de toneladas de ferro fundido contra 9 milhões produzidas pela Inglaterra. Contudo, esta possuía domínios coloniais imensamente maiores que os da Alemanha, o que perfaz uma contradição extremamente conflitiva. Nesta ordem de considerações, é impossível entender as guerras mundiais e suas consequências fora da óptica do capitalismo. Eric Hobsbawm menciona acertadamente a fusão entre a política e a economia na Era dos Impérios, apontando que "as 'fronteiras naturais' da Standard Oil, do Deutsche Bank ou da De Beers Diamond Corporation estavam no fim do universo, ou melhor, nos limites de sua capacidade de expansão ${ }^{141}$ ". A partilha consensual do planeta não poderia se dar indefinidamente, e a disputa pelo direito de explorar as colônias assumiu a forma de guerra aberta. Do ponto de vista das nações, Grã-Bretanha e Alemanha combatiam pela hegemonia imperialista mundial.

Encerrada a Primeira Grande Guerra, com o saldo de uma incrível destruição de capitais, as potências vencedoras logo trataram de cuidar de seus interesses. Hobsbawm observa que o Tratado de Versalhes era dominado por cinco preocupações: i) colapso de regimes na Europa e Revolução Russa; ii) controle da Alemanha enquanto potência militar; iii) redivisão do mapa da Europa para enfraquecer a Alemanha e suprir o espaço deixado pelo colapso dos impérios russo, austro-húngaro e otomano; iv) políticas internas dos países vitoriosos (Grã-Bretanha, França e EUA) e os atritos entre eles; v) impossibilitar outra guerra de iguais proporções. $O$ fracasso na maioria destes pontos foi mais que evidente.

No entreguerras, o espectro do bolchevismo assombrou a Europa em particular. Explodiram levantes revolucionários na Rússia, na Alemanha, na Itália e na Hungria dentro do intervalo de 1917 a 1923, todos derrotados, com exceção da experiência russa (a qual desembocou, inclusive, na III Internacional - que seria,

\footnotetext{
${ }^{139}$ LÊNIN, Op. Cit., 1987, p. 60.

140 LÊNIN, Op. Cit., 1987, p. 97.

${ }^{141}$ HOBSBAWM, Eric J.. Era dos extremos: o breve século XX: 1914-1991, 2. a ed.. Tradução de Marcos Santarrita. São Paulo: Companhia das Letras, 2001, p. 37.
} 
anos depois, degenerada pelo stalinismo). Outras lutas revolucionárias, também mal-sucedidas, explodiram na década de 1930, novamente na Alemanha, na França e na Espanha. O contragolpe das classes dominantes, na maioria dos casos, vestiu a carapuça do nazi-fascismo.

Impõe-se concluir que o preço que o proletariado pagou por sua derrota foi altíssimo: o constitucionalismo social, que encontrou seu maior expoente na República de Weimar, cedeu seu espaço ao totalitarismo como despotismo absoluto de classe e como combustível necessário à reedição da guerra imperialista. $\mathrm{Na}$ realidade, os governos totalitários eram tudo o que o modo de produção capitalista precisava para revigorar sua reprodução econômica, pois a destruição bélica abre novos caminhos para capitais que não encontram aplicação lucrativa em tempos de estagnação. A Grande Depressão do pós-1929 não teria sido efetivamente superada sem uma tragédia das proporções de 1939-1945.

A Segunda Guerra Mundial foi uma extensão da primeira, uma continuidade dos conflitos inter-imperialistas que o Tratado de Versalhes não conseguiu dirimir. Os assassinatos em escala industrial e a queima de capitais só fizeram aumentar, e o mundo não seria o mesmo depois deste confronto. A superioridade industrial e financeira dos EUA finalmente se concretizou em hegemonia política internacional. O fordismo encontrou uma oportunidade para prosperar, caracterizando-se não só pela racionalização da tecnologia (incorporando as técnicas tayloristas de decomposição da atividade, medição rigorosa do tempo e estudo meticuloso dos movimentos) e da divisão do trabalho, cujo maior expoente é a linha de montagem com suas funções fixas e repetitivas, mas também por sua visão sobre o todo. A elevação da produtividade, a ponto de permitir a produção em massa, de nada serviria sem um correlato consumo de massa. Mais que isso, o trabalho deveria ser estruturado de tal maneira que os operários (ou ao menos uma parcela considerável deles) pudessem ter tempo e renda suficientes para consumir. Haveria de se forjar um novo sistema de reprodução da força de trabalho, uma nova filosofia de controle e gerência do labor, uma nova psicologia, uma nova estética etc. Numa palavra, reestruturação produtiva (e conseqüentemente social).

Vale assinalar que na fase do entreguerras faltavam as condições necessárias para o amadurecimento do fordismo, não obstante as idéias de Ford e Taylor já fossem conhecidas. Os impedimentos eram, basicamente, a organização do trabalho, as tradições artesanais (os trabalhadores resistiram ao modelo fordista 
de jornadas rotinizadas) e a insuficiência da intervenção estatal no período. O último problema foi superado pela própria dinâmica da guerra, em que os esforços nacionais de mobilização e a situação de emergência propiciaram uma atuação resoluta do Estado na economia, principalmente no campo financeiro ${ }^{142}$.

Já a oposição dos trabalhadores foi reduzida pela cooptação dos sindicatos mais influentes (lembrando que os maiores partidos da classe trabalhadora já haviam sido assimilados pelo regime burguês). Com as correntes mais subversivas enfraquecidas ou colocadas fora do caminho pela repressão policial e com as táticas colaboracionistas que se fizeram dominantes entre os dirigentes das organizações burocratizadas, enfim apareceu o momento adequado para os acordos.

A função central das organizações sindicais foi garantir uma relação de troca. Elas se ocupavam de colaborar com a administração das empresas em seus planos de expansão da produtividade à custa da degradação e da rotinização fordistas (convencendo ou pressionando a base para que se submetesse às condições de trabalho), pleiteando benefícios sociais e ganhos de salário real como contrapartida. Se a concentração de operários no chão de fábrica, decorrente da estrutura produtiva fordista baseada nas grandes fábricas, ameaçava os capitalistas, havia como contrapeso as entidades sindicais que zelavam pelo compromisso entre as classes. Cuidavam para que as reivindicações da base não ultrapassassem a lógica da mera barganha em torno do preço da força de trabalho, para que a luta de classes se processasse apenas nas negociações coletivas e no interior do direito do trabalho. Chancelando o arranjo compromissório, os governos social-democratas custearam o capital (investimentos) e o trabalho (direitos da cidadania concretizados pelo Welfare State) tanto quanto puderam.

O perfil do capitalismo no pós-guerra era, portanto, não apenas fordista. keynesianismo ascendeu à posição de corrente hegemônica no pensamento econômico, espelhando o modelo econômico que se enraizava na reprodução social $^{143}$. As ideias liberais foram ofuscadas ${ }^{144}$ pelo crescimento econômico inaudito

\footnotetext{
142 "A Segunda Guerra Mundial e sua esteira, no entanto, testemunharam uma extensão bastante grande das funções econômicas do Estado, de modo a torná-lo uma linha divisória qualitativa nesse aspecto. A forma que essa extensão tomou era menos a de qualquer contrôle direto sôbre a produção industrial, ou participação na mesma, do que uma grande extensão das despesas de Estado, e daí a influência de tais despesas sôbre o mercado, notadamente para os meios de produção ou bens de capital" (DOBB, Op. Cit., 1965, p. 472).

143 "Aceito amplamente a visão de que o longo período de expansão de pós-guerra, que se estendeu de 1945 a 1973, teve como base um conjunto de práticas de controle do trabalho, tecnologias, hábitos de consumo e configurações de poder político-econômico, e de que esse conjunto pode com
} 
proporcionado pela reconstrução dos países devastados pela guerra. O sistema capitalista desfrutava seus anos dourados.

Entretanto, a recuperação foi eficaz "em demasia". Os níveis de acumulação foram tão elevados que não havia mercados em número suficiente para garantir resultados lucrativos o bastante para as expectativas empresariais. Paralelamente, a indústria estadunidense, principal carro-chefe do capitalismo do pós-guerra, declinou perante a concorrência com o Japão e a Alemanha, principalmente, e o ramo automobilístico foi bastante ilustrativo quanto a isso.

O resultado desta acumulação em excesso foi a queda da taxa de lucros nos anos 70, que foi agravada pelos choques do petróleo. A reação ao problema operouse em duas frentes: na produção e na circulação. Na produção, partiu-se para a chamada "acumulação flexível ${ }^{145 ", ~ p e l a ~ q u a l ~ f o r a m ~ i n t r o d u z i d o s ~ n o v o s ~ p a d r o ̃ e s ~ d e ~}$ trabalho, produção e consumo voltados para a retomada de uma taxa de lucros atraente. As novas economias de escopo, orientadas para a redução de estoques (produção flexível, variada e em pequenos lotes), para a maximização do aproveitamento do trabalho utilizado e para o atendimento de demandas localizadas, com enfoque na qualidade dos bens oferecidos, derrotaram as economias de escala, de natureza fordista. A produção massificada e uniformizada já não dava conta das necessidades de valorização, não podendo competir com o modelo just-in-time.

É neste contexto que desponta o toyotismo, uma variante da acumulação flexível em comento, caracterizando-se pela polivalência do trabalho e pela absorção das técnicas de gestão dos supermercados dos EUA (que deram origem ao kanban - método de reposição dos produtos escoados e de administração do estoque) e as práticas de subcontratação, imersas num universo de horizontalização e

razão ser chamado de fordista-keynesiano" (HARVEY, David. Condição pós-moderna: uma pesquisa sobre as origens da mudança cultural, 16. ${ }^{a}$ ed.. Tradução de Adail Ubirajara Sobral e Maria Stela Gonçalves. São Paulo: Edições Loyola, 2007, p. 119).

144 "O capitalismo do pós-guerra foi inquestionavelmente (...) um sistema 'reformado a ponto de ficar irreconhecível' (...). Essencialmente foi uma espécie de casamento entre liberalismo econômico e democracia social (...), com substanciais empréstimos da URSS, que fora pioneira na idéia de planejamento econômico. Homens como Friedrich von Hayek (...) tinham defendido a pureza do mercado na Grande Depressão. Continuavam a condenar as políticas que faziam de ouro a Era de Ouro, quando o mundo ficava mais rico e o capitalismo (...) tornava a florescer com base na mistura de mercados e governos. Mas entre a década de 1940 e a de 1970 ninguém dava ouvidos a tais Velhos Crentes" (HOBSBAWM, Op. Cit., 2001).

145 "A acumulação flexível, como vou chamá-la, é marcada por um confronto direto com a rigidez do fordismo. Ela se apóia na flexibilidade dos processos de trabalho, dos mercados de trabalho, dos produtos e padrões de consumo. Caracteriza-se pelo surgimento de setores de produção inteiramente novos, novas maneiras de fornecimento de serviços financeiros, novos mercados e, sobretudo, taxas altamente intensificadas de inovação comercial, tecnológica e organizacional" (HARVEY, Op. Cit., 2007, p. 140). 
desconcentração das cadeias produtivas. E é este mesmo fator que explica o crescimento do setor de serviços em proporção jamais vista no fordismo, não só no varejo, distribuição e transporte, mas também nas consultorias, finanças, seguros etc. Os aperfeiçoamentos tecnológicos, notadamente na área da comunicação, jogaram água neste mesmo moinho.

Na circulação, notável foi o fenômeno da financeirização. A crise da década de 70 impulsionou a busca por meios alternativos de lucratividade, e a esfera das finanças revelou-se deveras receptiva ao montante de capitais que passou a desenhar a produção industrial. Este movimento contou ainda com o apoio das políticas econômicas dos EUA. A elevação dos juros em níveis draconianos e o abandono de Bretton Woods (isto é, do padrão dólar-ouro) só fizeram fomentar a especulação (o que não se pode fazer com uma moeda sem lastro, essencialmente fiduciária?) e a migração de capitais oriundos da produção, coroando o declínio da hegemonia industrial estadunidense e os esforços do governo em compensar esse declínio com o fortalecimento de sua moeda (paralelamente aos incrementos no campo armamentista).

Na outra ponta do Pacífico, a restauração capitalista venceu as muralhas da China, obtendo igual triunfo na Rússia e no Leste Europeu na década seguinte. O discurso neoliberal fez-se dominante no mundo, em meio a uma aparente inexistência de alternativas ao mercado. A globalização, que é antes uma mundialização do capital (e do capital financeiro, em particular) e das políticas neoliberais ${ }^{146}$, abre uma era em que a exploração capitalista e as formais mais fetichizadas dessa exploração cobrem o planeta em proporção inédita. Se voltarmos aos apontamentos de Marx e Engels no Manifesto Comunista acerca da conquista do globo pelo capitalismo, bastaria acrescentar a exportação de capitais e a ascensão das finanças para realçar a atualidade daquele documento, que já deixava indicações sobre a natureza expansionista do modo de produção capitalista.

\footnotetext{
${ }^{146}$ François Chesnais destaca que o adjetivo "global" surgiu no começo dos anos 1980, no âmbito das grandes escolas de administração empresarial dos EUA. Foi popularizado pelos consultores de estratégia e marketing e depois se difundiu amplamente com a imprensa econômica e financeira de língua inglesa, integrando as bases do discurso neoliberal. Ele nos informa que "em matéria de administração de empresas, o termo era utilizado tendo como destinatários os grandes grupos, para passar a seguinte mensagem: em todo lugar onde se possa gerar lucros, os obstáculos à expansão das atividades de vocês foram levantados, graças à liberalização e à desregulamentação; a telemática e os satélites de comunicações colocam em suas mãos formidáveis instrumentos de comunicação e controle; reorganizem-se e reformulem, em conseqüência, suas estratégias internacionais" (CHESNAIS, François. A mundialização do capital. Tradução de Silvana Finzi Foá. São Paulo: Xamã, 1996, p.23).
} 
A partir de então, começa o naufrágio do Estado de bem-estar social. O receituário neoliberal rotulou a legislação trabalhista como obstáculo ao crescimento e como fator de desemprego. A seguridade social foi anatematizada como um fardo insuportável à sociedade. O mercado foi elevado à condição de medida de todas as coisas. Uma autêntica divindade, à qual não caberia opor qualquer alternativa.

O impacto das mudanças por que passou o capitalismo nos direitos sociais será esmiuçado no item em que os relacionarmos com a reprodução econômica e com a luta de classes. Antes, convém efetivar um enquadramento jurídico destes direitos à luz da teoria pasukaniana.

\subsection{Forma jurídica e direitos sociais}

Alguns representantes da dogmática jurídica despenderam esforços hercúleos contra a nomenclatura dos direitos sociais, alegando, como quem ilumina a ciência com uma fabulosa revelação, que o direito só existe em sociedade, sendo sempre "social".

Uma crítica como esta serve apenas para denunciar a obtusidade de seus autores. O "social", aqui, aparece em nítido contraste com o "individual", a marca do liberalismo. Não é possível ignorar que o paradigma do direito liberal experimentou transformações ao longo da história. A questão é saber se estas transformações foram suficientemente extensas e incisivas para desnaturá-lo.

A concepção dominante sobre os direitos humanos de segunda dimensão os enxerga como uma resposta jurídica às desigualdades econômicas, uma compensação pelo desequilíbrio na distribuição da riqueza. Alguns autores chegam a captar o aspecto político destes direitos, apontando a concessão feita aos trabalhadores como meio de se apaziguar os ânimos revolucionários, conforme a famosa metáfora de se "entregar os anéis para preservar os dedos". Outros vão ainda mais longe, como é o caso de Fábio Konder Comparato:

O reconhecimento dos direitos humanos de caráter econômico e social foi o principal benefício que a humanidade recolheu do movimento socialista, iniciado na primeira metade do século XIX. O titular desses direitos, com efeito, não é o ser humano abstrato, com o qual o capitalismo sempre conviveu maravilhosamente; é o conjunto dos grupos sociais esmagados pela miséria, a doença, a fome e a marginalização. Os socialistas perceberam, desde logo, que esses flagelos sociais não eram cataclismos da natureza nem efeitos necessários da organização racional das atividades 
econômicas, mas sim verdadeiros dejetos do sistema capitalista de produção, cuja lógica consiste em atribuir aos bens de capital um valor muito superior ao das pessoas.

Os direitos humanos de proteção do trabalhador são, portanto, fundamentalmente anticapitalistas, e, por isso mesmo, só puderam prosperar a partir do momento histórico em que os donos do capital foram obrigados a se compor com os trabalhadores ${ }^{147}$.

Como se observa, o notável jurista localiza a historicidade dos flagelos sociais, afastando-se da noção ideológica que naturaliza as disparidades econômicas e suas consequências. Entretanto, haveremos de demonstrar seu equívoco ao afirmar que os direitos sociais seriam anticapitalistas. Na realidade, o que se constata é o exato oposto, a começar pelas determinações contidas na forma jurídica.

O direito, como estudamos anteriormente, é uma relação entre sujeitos que se espelha no circuito mercantil. No caso do direito do trabalho, chegamos a comentar, de passagem, que os polos da estrutura econômica (capitalista e trabalhador) são convertidos em figuras jurídicas, em contratantes nivelados pelo plano contratual, sendo que a diferença de ônus contratuais (maiores encargos para o empregador) em nada prejudica a exploração no chão de fábrica. Aliás, um mecanismo de espoliação lastreado numa operação mercantil não poderia apresentar-se de outra maneira a não ser sob a chancela da igualdade jurídica, que corresponde à equivalência dos bens trocados (força de trabalho e salário). Dedicaremos o último item do presente capítulo para aprofundar o tema e suas derivações mais importantes.

No que diz respeito aos direitos sociais, é bastante comum afirmar-se que eles se caracterizam por uma prestação positiva do Estado, em contraste com os direitos de primeira dimensão, cuja efetividade dependeria de uma abstenção da autoridade, ou seja, de uma conduta negativa que desse alguma abertura para o florescimento das liberdades individuais. Inclusive, este entendimento foi mitigado em alguma medida pelos esforços dos juristas progressistas, que, para enfrentar os argumentos conservadores da "reserva do possível", obtemperaram que mesmo os direitos civis e políticos dependem de condutas estatais positivas e, por isso, custosas, tal como a realização de eleições e a administração dos serviços de segurança. Seja como for, não nos deteremos neste assunto, dada a sua obviedade,

${ }^{147}$ COMPARATO, Op. Cit., 2010, pp. 66-67. 
muito embora jamais tenha ocorrido a alguns membros mais relutantes do Judiciário e da administração pública que qualquer direito tem o seu custo.

O que importa para nós é que esta prestação estatal é executada seguindo os ditames da forma jurídica. Quando, no capítulo precedente, comentamos a estrutura elementar do processo penal, indicamos que o Estado se desmembrava em duas funções: a de Estado-juiz, garante das relações jurídicas, e a de Ministério Público, parte interessada no processo e em contenda direta com o réu. Cumpre observar agora que esta ambivalência do Estado é extraída da contraposição inerente à sociedade burguesa entre o indivíduo e a coletividade, revelando-se nas diferentes atribuições do direito público (cuja origem privatista não pode nunca ser ignorada).

Leia-se agora uma passagem de Pasukanis sobre os papéis do Estado:

\begin{abstract}
Desde que o poder do Estado é representado como a encarnação de uma regra objetiva situada acima dos sujeitos-partes, ele se funde com a norma e torna-se o ponto mais elevado, impessoal e abstrato. A exigência do Estado surge como lei imparcial e desinteressada. Neste caso é praticamente impossível conceber o Estado como sujeito, seja porque está destituído de substancialidade, seja porque transformou-se em uma garantia abstrata das relações entre os sujeitos reais, proprietários de mercadorias. Esta concepção, como a concepção mais pura do Estado, é aquela defendida pela escola normativista austríaca, com Kelsen à frente. Nas relações internacionais, ao contrário, o Estado não surge como a encarnação de uma norma objetiva, mas como titular de direito subjetivo, isto é, com todos os atributos da substancialidade e do interesse egoísta. $O$ Estado desempenha o mesmo papel, quando atua a título de fisco, como parte em um litígio com pessoas privadas ${ }^{148}$.
\end{abstract}

O jurista soviético nota que, para além da função judicante, o Estado pode comportar-se, ele mesmo, como sujeito de direito, ilustrando com os casos do direito internacional (em que os Estados são partes em processos apreciados por cortes internacionais) e do direito tributário. $E$ aqui se impõem algumas colocações relevantes.

Consideramos o direito tributário como uma forma social especificamente capitalista, e há duas razões fundamentais que sustentam esta assertiva. Em primeiro lugar, deve-se perceber que a figura do tributo, que nada mais é do que a extração forçada de riqueza possuída por um agente econômico (o indivíduo proprietário ou uma coletividade) em benefício de um poder centralizado, alcança sua expressão mais bem acabada no capitalismo, onde o contribuinte, enquanto portador de mercadoria, é individualizável. Em segundo lugar, é típico da

${ }^{148}$ PASUKANIS, Op. Cit., 1989, p. 139. 
democracia burguesa revestir a exação estatal de mecanismos jurídicos e administrativos de controle, tornando-a previsível e passível de judicialização.

Em espírito de síntese, não seria desarrazoado definir o ramo do direito tributário como sendo a medida do poder do fisco e a quantificação da violência estatal admitida contra o patrimônio privado, em nítido contraste com a tão temida figura do confisco, que seria o uso desmedido das atribuições fiscais do Estado contra os cidadãos. Aqui, a figura da cidadania é fundamental. A autoridade, enquanto fisco, não se depara com súditos, e sim com contribuintes munidos de direitos. Há entre eles uma relação jurídica, cuja tutela dos direitos que dela decorrem cabe novamente ao Estado, mas agora enquanto um tribunal independente, e não mais como fisco. O Poder público cinde-se em duas identidades distintas para não julgar em causa própria, assim como aquela alma boa de Setsuan, do texto de Brecht, que teve de se bipartir em personalidades apartadas para enfrentar as agruras de seu ambiente.

Ao nos defrontarmos com os direitos sociais, salta aos olhos que a atuação estatal orienta-se em sentido análogo ao explanado quando estivermos no domínio do direito público. O Estado porta-se como sujeito devedor em face do beneficiário da prestação, que assume a posição de credor. Os direitos sociais, como direitos subjetivos que são, exigem três figuras essenciais: credor, devedor e objeto ${ }^{149}$. Não que isto afete o seu privatismo ou o seu publicismo, dependendo do ângulo. Aliás, cabe aqui a explicação de que estes direitos aparecem no direito público e no direito privado, constituindo uma categoria alternativa que transita por tais ramos. A abrangência dos direitos de segunda geração não permite a sua inclusão em apenas um dos domínios:

Atualmente, a abrangência subjetiva e objetiva dos direitos sociais é
extremamente maior. Assim, estes não se caracterizariam, no nosso
entender, como uma categoria distinta dos direitos público e privado, mas
permeariam ambos nos instantes em que ocorressem traços comuns
distintivos e que necessitassem de ser tratados sob a perspectiva da
proteção social maximizada. Expliquemos: pode haver direito social tanto
em áreas tradicionalmente afetas ao direito privado (como exemplo certas
relações de consumo ou aquelas estabelecidas por pequenos contratantes
no sistema financeiro de habitação) ou também ao direito público (como

${ }^{149}$ Confira-se a ponderação sobre esta estrutura dos direitos subjetivos em LOPES, José Reinaldo de Lima. Direito subjetivo e direitos sociais: o dilema do Judiciário no Estado Social de Direito. In: FARIA, José Eduardo Campos de Oliveira (org.). Direitos humanos, direitos sociais e justiça. São Paulo: Malheiros, 1994. 
exemplo tradicional tem-se o direito previdenciário, mas também seria possível a sua constatação no direito sanitário ou no direito tributário) ${ }^{150}$.

Nossa análise começa pela seguridade social, que certamente integra 0 direito público. Na seguridade, e em especial na previdência social, não há dúvidas de que a forma jurídica, com todo o seu individualismo arraigado, está presente nos direitos humanos sociais. O segurado coloca-se como portador de um direito subjetivo em face do sistema de seguridade, o titular da obrigação correspondente. E ao buscar alguma prestação do Estado para si, pode encontrar resistência por parte de órgãos administrativos encarregados de atender a população com serviços de saúde, assistência e previdência (evento cada vez mais comum com as diretivas neoliberais de amesquinhamento, contingenciamento e privatização dos serviços públicos). Restará ao cidadão procurar a Justiça e pleitear, dentro da formação clássica e liberal de uma lide (pretensão à qual se opôs resistência), uma ordem que obrigue a administração a conceder aquilo que sonegou. A bipartição do Estado, bem ao gosto do que acontece com a forma jurídica no direito público, aparece com clareza.

E mais. A concessão dos benefícios jamais é abundante. $O$ "generoso" Estado social os concede com a "avareza de um Shylock". Anote-se a observação de Robert Castel, que o define como "sobretudo parcimonioso, calculador e facilmente desconfiado quanto ao uso que é feito de seus subsídios", sendo ainda "mais o que busca ajustes mínimos do que o distribuidor desinteressado de uma massa de óbulos ${ }^{151}$ ". Da mesma maneira que o direito penal mede o uso da força bruta estatal contra a liberdade e que o direito tributário mensura o uso desta força contra o patrimônio no ato da exação, os direitos sociais dimensionam a medida exata da alocação de uma fração do tesouro nacional para disponibilizar estoques de força de trabalho no exército industrial de reserva. Sua razão de ser é a necessidade do capitalismo moderno de receber suprimentos de mão-de-obra cuja reposição seja o menos custosa possível. Seria inadmissível um Estado esbanjador nos seus gastos com saúde, educação, habitação e previdência para o povo.

No próximo item, comentaremos as atribuições econômicas do Estado no sentido de garantir a reprodução social (confira-se nosso primeiro capítulo).

150 SOUTO MAIOR, Jorge Luiz; CORREIA, Marcus Orione Gonçalves. O que é Direito Social?. In: CORREIA, Marcus Orione Gonçalves (org.). Curso de direito do trabalho. Vol. I. São Paulo: LTr, 2007, p. 24.

${ }^{151}$ CASTEL, Op. Cit., 1998, p. 346. 
Deixemos para depois o aprofundamento. Por ora, sabemos que, para atingir seus objetivos, a entidade estatal aplica penas, cobra tributos, organiza a administração etc. E ela o faz, no capitalismo, de forma calculável e previsível, sempre se dirigindo a sujeitos de direito. Ora, com a seguridade social não é diferente, mas isto se a encararmos como uma função moderna de Estado. O poder público encarregou-se de prover o exército industrial de reserva, poupando a classe capitalista deste fardo. O custo de manutenção daqueles que não estão aptos para o labor é rateado por toda a sociedade, ao que o capital agradece, dada a consequente diminuição de suas despesas com capital variável.

Cabe ao direito, e particularmente ao direito da seguridade social, governar o uso desta atribuição estatal. Quando observamos a forma jurídica aplicada à Previdência social, por exemplo, sua função aparece imediatamente, qual seja: contabilizar a quantidade de proteção a que faz jus o segurado, da mesma maneira que contabiliza a quantidade de liberdade que o condenado pela Justiça criminal deverá perder para quitar seu "débito" com a sociedade. O raciocínio é o mesmo, mudando-se apenas a direção. O direito previdenciário quantifica o crédito que 0 segurado adquire em face da coletividade e lhe dá o equivalente em termos de benefício, prestando homenagem à igualdade jurídica.

Note-se que o critério da equivalência está mais preocupado com a possibilidade de percepção em excesso de benefícios do que com a possibilidade de uma percepção abaixo do que corresponderia, por direito, às contribuições. Como bem disse Castel, para além de parcimonioso e calculista, o Estado social é "desconfiado". Ele se posta diante dos segurados e não gosta nada do quadro que se afigura diante de seus olhos: uma população de sujeitos de direito, de indivíduos constituídos à imagem e semelhança de um guardião de mercadorias. Uma constelação de "proprietários" abstratos que só cuidam de si, que buscam obstinadamente a maximização de seu interesse individual, que fazem do utilitarismo de Bentham sua profissão de fé. O segurado, nesta ordem de considerações, é mais que um oportunista em potencial; é como se ele estivesse inclinado a priori a querer retirar da coletividade mais do que the entregou, afrontando a regra de ouro da troca de valores equivalentes, esta máxima da sociedade do capital. Contra tão ignominioso risco de "enriquecimento sem causa", aparece o direito, o qual, ao proteger os contratantes do egoísmo do outro, também 
se ocupa de proteger a sociedade do egoísmo presumido de seus integrantes individualizados.

Para que não haja dúvidas, contemplemos as ponderações de Castel sobre a "propriedade social", que é a somatória das contribuições dos segurados e, nesta qualidade, encontra-se adstrita aos usos da seguridade social:

\begin{abstract}
O capitalismo realiza aí uma estranha operação de alquimia. Os poderes da propriedade são conservados. O direito está ligado ao depósito da cotização, é o que the dá seu caráter incondicional, diferentemente do direito ao socorro: como pagou, o cotizador é um detentor de direito no sentido absoluto e não importa o que lhe aconteça - mesmo se não tem 'necessidade' de sua prestação para sobreviver, se é, por exemplo, rico proprietário ao mesmo tempo que aposentado. Assim, essa propriedade de transferência não é incompatível com a propriedade clássica. Respeita as prerrogativas da propriedade privada e até as prolonga: só o pagamento individual dá acesso ao direito coletivo ${ }^{152}$.
\end{abstract}

O segurado terá seu caso avaliado não por suas necessidades concretas, e sim pelo seu histórico de cotizador, isto é, por sua capacidade de honrar o sinalagma da relação jurídica que conserva com o Estado-providência, capacidade esta que o promove a "co-proprietário" da propriedade social. O "social", aqui, está somente no fundo onde as contribuições são armazenadas, e não guarda qualquer relação com o modo de ser do direito em si. O cumprimento dos requisitos da prestação previdenciária é uma caminhada solitária, na medida em que o segurado, independentemente do que lhe ocorra, não poderá contar com as cotizações de outrem, por mais superavitário que seja o sistema. Ele é lançado à sua própria sorte, e precisa se acobertar como mônada isolada. Conquista e frui o direito na solidão de sua ilha ${ }^{153}$, com nítida similaridade em face do cidadão-proprietário que desfruta de seus pertences. Não há solidariedade real.

Cada proprietário de uma cota social, assim, encontra no seu semelhante um obstáculo à sua liberdade na forma de desfrute do sistema, tal como Marx criticou nos direitos humanos de primeira dimensão. O cidadão só é considerado solidário quando cotiza. Tão logo que, por alguma razão (como o desemprego), deixe de

\footnotetext{
${ }^{152}$ CASTEL, Op. Cit., 1998, p. 406.

${ }^{153}$ Anote-se a reflexão de Flávio Batista em sua genial tese de doutorado: "Todo direito subjetivo, por mais que a doutrina jurídica tente atribuir-lhe o aspecto coletivo ou difuso, é individual, porque, no limite, somente assim pode ser exigido e fruído. Além disso, todo direito subjetivo é patrimonial, se não originariamente, ao menos se tornando patrimonializável com a sistemática da responsabilidade pelo descumprimento das obrigações jurídicas" (BATISTA, Flávio Roberto. Crítica da tecnologia dos direitos sociais: uma contribuição materialista histórico-dialética. Tese (doutorado). São Paulo: USP, 2012, p. 158).
} 
contribuir, passa a ser estigmatizado como um aproveitador, um "caronista" ("free rider"). Contra ele se levantam suspeitas indignas, fomentando interpretações judiciais estarrecedoras, conforme relata Marcus Orione Gonçalves Correia:

\begin{abstract}
Em direitos sociais, para a sua melhor interpretação, é indispensável que abandonemos a péssima ideia de que se faz do outro, especialmente o outro excluído, mais pobre. A imagem desse outro como alguém que quer tirar vantagem do sistema, que se coloca em situação de trapaceiro ou vagabundo, deve ser imediatamente afastada. (...) É de se abismar mesmo com algumas expressões utilizadas para os direitos sociais, tais como benefício previdenciário (benefício!), período de graça e coisas deste tipo. (...) Também o é a velha e já surrada presunção de má-fé de quem postula o direito social, como já visto anteriormente. Assim, dá-se, por exemplo, com alguém que vai postular um auxílio-doença. Não é incomum a pergunta, oriunda mesmo do que é reproduzido nos noticiários de TV, se a pessoa não está fingindo a doença. A eterna presunção de má-fé em que é concebido o que busca o direito social. A desconfiança do opressor com as malícias, para enganá-lo, do oprimido ${ }^{154}$.
\end{abstract}

Em que pese o estigma sobre os pobres, porém, há de se admitir que o protagonista da peça que apresentamos é o homem abstrato das primeiras declarações de direitos. Se ele é um trabalhador que experimentou vicissitudes e que quer apenas assegurar seu futuro, ou se é o herdeiro de uma fortuna colossal, por exemplo, isto em nada importa à forma jurídica, que nele encontra nada mais que a imagem genérica de um segurado, a face "social" do sujeito de direito. Como qualquer outro sujeito de direito, enfrentará a desconfiança da administração e terá de levar seu conflito em face dela ao Judiciário, esta instituição que, apesar de ser poder público, nem por isso se confunde com o órgão interpelado, que constará como parte no processo. E para completar, o segurado está irremediavelmente separado da comunidade. Quando pretende acioná-la para conseguir socorro, ela se traveste de Estado e se opõe a ele, interpelando-o de volta como átomo, é dizer, negando-Ihe o pertencimento a uma classe estruturada e dissolvendo-o num oceano de individualidades volatilizadas.

Aliás, o escamoteamento das classes, próprio do direito, permanece e se incrementa nos direitos sociais. Assim como, na seara justrabalhista, o trabalhador abstrai sua origem econômica para se defrontar com seu algoz na qualidade de contratante, este mesmo trabalhador, ao recorrer à seguridade social, abstrai

154 CORREIA, Marcus Orione Gonçalves. Interpretação dos direitos fundamentais sociais, solidariedade e consciência de classe. In: CANOTILHO, J. J. Gomes; CORREIA, Marcus Orione Gonçalves; CORREIA, Érica Paula Barcha (Coord.). Direitos fundamentais sociais. São Paulo: Saraiva, 2010, p. 133. 
novamente seu pertencimento a uma classe esmagada pelo Estado burguês; sublima-se esta entidade que converte os recursos públicos em instrumento de repressão policial e de penúria para o proletariado, penúria imediatamente associada ao rentismo do capital financeiro e à sustentação do capital produtivo. A ideologia do Estado como provedor do bem comum ganha reforço com o direito, e particularmente com os direitos sociais, cuja expressão jurídica propõe uma imagem distante daquilo que o aparelho estatal efetivamente é: um comitê executivo dos assuntos da burguesia.

Graças ao direito, o horizonte imediato do trabalhador, ao se esbarrar com o capital e o Estado, é judicializar sua demanda. No caso dos direitos sociais, sobressai a judicialização da conflitividade entre os trabalhadores e o aparato estatal, afastando-se, deste modo, a possibilidade e a imperatividade de se aniquilar o Estado. Analogamente, o direito do trabalho conspira constantemente a favor da resolução judicial das tensões e contra a luta direta dos trabalhadores (greve, ocupações de fábrica etc.).

Retomemos o esquema básico dos direitos humanos que mencionamos na introdução, e que resume o pensamento hegemônico sobre o tema. A liberdade contida nos direitos civis e políticos seria, na geração seguinte, complementada pela igualdade contida nos direitos econômicos e sociais, cabendo-lhes, até mesmo, remediar o formalismo exacerbado da geração pioneira. A insuficiência desta leitura repousa no seguinte: de acordo com nossas primeiras observações sobre os direitos de segunda dimensão, divisamos que a igualdade oferecida pelo direito é a mesma do modelo anterior. Repetem-se o nivelamento e a abstração da condição de classe e dos conflitos que a envolvem. Além do quê, a natureza egoística e atomística do sujeito jurídico segue conduzindo a distribuição dos direitos sociais. Os destinatários destes direitos são sempre subjetivados.

Pudemos perceber, em suma, que o segurado é ainda um sujeito de direito. Primeiramente porque precisa descolar-se de seu agrupamento e acionar um poder externo para dirimir conflitos com a administração. Ao final, o órgão administrativo e o titular de um direito social acabam nivelados numa lide, não importando quem ganhará a contenda, e esta é a igualdade jurídica formal, a única afiançada pelo direito. Depois, porque se presume contra o titular do direito social o ímpeto utilitarista. E no caso da previdência, inclusive, acha-se ainda o inconfundível 
elemento individualista da permuta ${ }^{155}$, da correlação entre contribuições e benefício. É o reino do cada cotizador por si, do salve-se quem puder. O "homem egoísta", "separado do homem e da comunidade", não estava de passagem na "afirmação histórica dos direitos humanos".

Qualquer semelhança com a estrutura mercantil da sociedade capitalista não é mera coincidência, e sim sobredeterminação. A forma jurídica, inicialmente adstrita à circulação imediata das mercadorias, foi angariando novos domínios à medida que o capital foi se apossando da reprodução social. Logo, é insustentável, para não dizer quimérica ou cerebrina, a interpretação corrente pela qual os direitos humanos seriam burgueses apenas na sua origem, sendo redimidos na geração seguinte graças às supostas universalidade e concretude dos direitos sociais. A continuidade da forma jurídica lança por terra a tese de uma "autocorreção" ideal dos direitos humanos. Até porque, convenhamos, as formas sociais não são dadas à autocrítica. Kashiura Jr. corrobora a ideia que tentamos passar:

\begin{abstract}
O que ocorre, na realidade, não é uma transformação cabal que faz os direitos humanos 'mudarem de lado', tampouco uma completa libertação com relação à sua gênese histórica, mas uma alteração de conteúdo, ou melhor, uma extensão da sua forma para conteúdos anteriormente estranhos a ela. É o mesmo que se passa com a forma da mercadoria, que num certo contexto passa a englobar coisas que anteriormente não englobava, como a terra, ou com a forma do direito, cuja gênese é a relação privada entre proprietários de mercadorias, mas que passa a englobar relações entre indivíduo e Estado ${ }^{156}$.
\end{abstract}

Não se deve esquecer: os direitos humanos sociais são ainda direitos humanos, e os direitos humanos, por sua vez, são ainda direito. A assimilação de novos conteúdos pela forma jurídica nunca é um acontecimento inocente.

\title{
4.3. Luta de classes, reprodução econômica e direitos sociais
}

\footnotetext{
${ }^{155}$ Lembrando que o caráter sistêmico de contribuições e de equilíbrio em nada altera a relação de troca, que é apenas "diferida", para se usar a expressão de Batista: "A previdência social nada mais é do que uma relação de troca diferida: recebe o benefício aquele que, atingido pela contingência, tiver feito previamente suas contribuições para a manutenção do regime. É claro que, evidentemente, a equivalência não será definida individualmente, mas na perspectiva de equilíbrio entre todos os participantes do sistema de previdência social. Eis aí mais uma característica prevista no artigo 201 da Constituição Federal: a necessidade de adoção de critérios que preservem o equilíbrio financeiro e atuarial. Em outras palavras, a previdência social é tão socialista quanto um contrato de seguro, ou seja, nada" (BATISTA, Op. Cit., 2012, p. 181).

${ }^{156}$ KASHIURA JR., Crítica da Igualdade Jurídica: contribuição ao pensamento jurídico marxista. Op. Cit., 2009, p. 141
} 
Não nos basta demonstrar a natureza capitalista dos direitos sociais apenas com relação à forma jurídica. É hora de sustentarmos esta tese levando em conta o conteúdo das atividades estatais que perfazem esses direitos.

Comecemos pela referência "inaugural ${ }^{157 "}$ dos direitos humanos sociais: a Constituição de Weimar. Segundo autores como Comparato, nela estaria corporificado o compromisso ao qual a burguesia alemã foi obrigada a se vincular em virtude do ascenso operário da época. A função social da propriedade consagrada no art. 153 (com a célebre redação de que "a propriedade obriga"), as disposições referentes à educação, a previsão de políticas de pleno emprego e o abrigo de garantias trabalhistas e previdenciárias seriam indícios de um "golpe" desferido contra o capitalismo, uma verdadeira imposição de baixo às elites alemãs.

Existe algo de verdadeiro nesta afirmação. Se é óbvio que tais medidas em nada alteram as relações de produção capitalistas, também é certo que elas não surgiram espontaneamente, ou que as classes dominantes tenham lhes apoiado de bom grado. O erro está em imaginar alguma forma de subversão nelas. Não que elas não sejam preferíveis ao constitucionalismo liberal clássico. O que acontece é que os juristas progressistas, entusiasmados com o compromisso firmado entre as classes, ignoram que foi por ele que o operariado alemão acabou politicamente desarmado, sendo esta uma decisiva fonte de derrotas. Pensemos na impotência do proletariado em deter o avanço do nazismo, ao que se devem adicionar outros fatores, é claro (como a política suicida do "social-fascismo" encampada por Stálin).

Quando se fala em Weimar, é comum esquecer as armadilhas da colaboração de classes. Um olhar mais atento aos eventos históricos faz-se exigível:

A formação da república alemã [de Weimar] desvendou a verdadeira função
do contrato social. Teve início com os seguintes contratos: o primeiro, e
mais importante, foi aquêle realizado entre Ebert de um lado e Hindemburgo
e Groener, por outro (...). Êsse contrato estabelecia, do lado positivo, o
restabelecimento da 'paz e ordem', e, do lado negativo, a luta contra o
bolchevismo. O chamado acôrdo Stinnes-Legien, de 15 de novembro de
1918 , deveria exercer o mesmo efeito na esfera social; os empregadores
prometeram não tolerar os sindicatos organizados sob coação e reconhecer
sòmente os independentes, colaborar com êles, e fixar condições de
trabalho por meio de contratos salariais. Na verdade, esse acôrdo não
sòmente significava o fim do bolchevismo como também o fim da
possibilidade de qualquer espécie de socialismo e fornecia a base do

157 Antes houve a Constituição mexicana de 1917, que normalmente é citada, e a Constituição soviética de 1918, que normalmente é mantida sob as sombras nas narrativas dos juristas. Escolhemos a Carta Weimeriana pelo seu contexto de aguda luta de classes num país de capitalismo desenvolvido e pela sua proeminência nos debates acerca do assunto. 
sistema sob o qual viveu a Alemanha de 1918 a 1930. No dia 4 de março de 1919, o Partido Social-Democrata de Berlim e o Gôverno do Reich concordaram com a introdução de conselhos nas fábricas e com a legalização de sua posição na Constituição. Foi tornado bem claro que tais conselhos nada teriam em comum com os conselhos dos soviéticos, de trabalhadores revolucionários e de soldados. Pelo acôrdo de 26 de janeiro de 1919 entre o Reich e os estados federados ficou garantida a organização federal do Reich. O quinto e último contrato (que na verdade incluía todos os outros) entre os três partidos de Weimar - o do Centro, o SocialDemocrata e o Democrático - estatuía a conservação da velha burocracia e do Judiciário, rejeitava o sistema soviético, estabilizava o poder político da Igreja, sancionava as liberdades civis, embora um tanto restritas por novos direitos sociais fundamentais, e introduzia a democracia parlamentar ${ }^{158}$.

O cerne do pacto da social-democracia com os representantes oficiais do capital foi o combate ao bolchevismo e à sua linha de poder operário. Nada mais prático: a burocracia capitulacionista manteria seus privilégios de aristocracia operária, ao passo que os burgueses seriam beneficiados com o isolamento da esquerda mais radical. E nas circunstâncias da época, a manobra mostrou-se vital. A burguesia germânica olhou para suas adjacências a leste e torceu o nariz para o que viu acontecer no antigo império russo. Um regime monárquico, com suas excrescências semifeudais, estava sendo sepultado por uma classe trabalhadora extraordinariamente impaciente com a fome e a guerra. E como se não bastasse, a derrocada do regime evoluiu rapidamente para a expropriação das classes dominantes, isto é, para a defloração da propriedade privada num curso espetacular de revolução permanente ${ }^{159}$.

O fim da guerra de 1914-1918 propiciou na Alemanha uma situação semelhante à que a Rússia se encontrava. A classe burguesa ligou os pontos e percebeu que poderia ser a próxima a ser expropriada, sobretudo diante do insistente internacionalismo de Trotsky e Lênin ${ }^{160}$. Aliou-se por conveniência à social-democracia e apoiou um regime republicano de democracia liberal com uma

\footnotetext{
${ }^{158}$ NEUMANN, Op. Cit., 1969, p. 58

159 Trotsky resumiu assim sua teoria sobre a revolução permanente: "A ditadura do proletariado, que sobe ao poder como força dirigente da revolução democrática, será colocada, inevitável e muito rapidamente, diante de tarefas que a levarão a fazer incursões profundas no direito burguês da propriedade. No curso de seu desenvolvimento, a revolução democrática se transforma diretamente em revolução socialista, tornando-se, pois, uma revolução permanente" (TROTSKY, Leon. A teoria da revolução permanente. Tradução de Diego Siqueira e Hermínio Sacchetta. São Paulo: Instituto José Luís e Rosa Sundermann, 2010, p. 314)

${ }_{160}$ Leon Trotsky ficou conhecido como o principal expoente do internacionalismo na sua ardorosa polêmica contra a tese do socialismo num só país. Seria injusto, contudo, ignorar todo o trabalho de Vladimir Lênin em favor da estratégia internacionalista. Na Conferência de Zimmerwald, apenas a título ilustrativo, "Lenin enxergava a necessidade e a urgência da construção da III Internacional. No entanto, Rosa Luxemburgo e Trotsky opinavam que se deveria ir mais devagar e que o central era realizar a batalha contra a guerra" (SAGRA, Op. Cit., 2010, p. 33).
} 
constituição compromissória. Paralela e decisivamente, cuidou para que Rosa Luxemburgo e Karl Liebknecht, importantíssimos dirigentes revolucionários (apesar de algumas discordâncias com o bolchevismo), fossem eliminados, lançando as alas mais avançadas do operariado germânico numa crise de direção.

Moral da história: o capital fez concessões, mas o fez de modo a intervir no movimento operário, promovendo o conservadorismo da social-democracia e isolando o radicalismo dos setores mais à esquerda. Poucos anos depois, a revolução alemã foi derrotada, tendo como inimigo, além dos capitalistas, nada menos do que o principal partido de origem operária da Europa, herdeiro do prestígio amealhado pelos anos de sucesso da II Internacional. Não é tão simples, então, dizer que a burguesia teve de baixar a cabeça depois de sofrer um golpe. Politicamente, o compromisso weimariano foi muito mais oneroso para o operariado. O reformismo insculpido nos direitos da Carta de Weimar tem como pressuposto a promoção das organizações mais alinhadas e acomodadas ao regime político. $O$ SPD alemão, com sua política, avalizou não só um capitalismo decorado com medidas reformistas, mas também as instituições do regime burguês.

A colaboração de classes é indispensável para o dimensionamento dos direitos sociais, já que nela está inscrita uma concepção ideológica de cidadania social. Ela sugere que o capitalismo pode assegurar a todos um lugar ao sol, que é inteiramente concebível satisfazer as necessidades das massas sem se recorrer à drástica estratégia da abolição das classes.

Robert Castel chama a atenção para o fato de que o "social" surge, em suas origens do fim do século XIX, como uma alternativa essencialmente compromissória tanto à insuficiência da filantropia das igrejas e associações de socorro como ao radicalismo dos socialistas. Para o autor, significa:

(...) não mais dissolver os conflitos de interesse pelo gerenciamento moral nem subverter a sociedade pela violência revolucionária, mas negociar compromissos entre posições diferentes, superar o moralismo dos filantropos e evitar o socialismo dos 'distributivistas' ${ }^{\text {'161. }}$.

O elemento "social" contido nos direitos humanos de segunda dimensão advém da "questão social", comumente narrada como um novo olhar sobre o pauperismo. Um novo olhar, pois o pauperismo era considerado, em momento

${ }^{161}$ CASTEL, Op. Cit., 1998, p. 345. 
anterior, como mera fonte de $\operatorname{crimes}^{162}$, e não de revoluções. Pudera: o proletariado, como classe revolucionária, emergiu somente com a industrialização capitalista. A pobreza industrial demonstrou-se politicamente diferente da pobreza pré-industrial.

A conhecida encíclica Rerum Novarum, de 1891, é bastante ilustrativa. A Igreja Católica deixou de se contentar com o assistencialismo paroquial, convocando abertamente o Estado para intervir nas condições de trabalho e de vida dos operários. Era preciso combater as perigosas ideias socialistas, o que deveria se dar pelo combate às causas. Imaginava-se que a composição entre as classes poderia afastar a classe operária das aspirações radicais e subversivas pela atenuação de seu sofrimento.

Na época do constitucionalismo social (início do século XX), a ideologia da colaboração de classes, apesar de influente, ainda não havia atingido suas culminâncias. Foi apenas com os êxitos eleitorais da social-democracia europeia após a Segunda Guerra Mundial que ela se impôs com peso. Daí a incorporação do elemento social ao conceito liberal de cidadania. T. H. Marshall, ao testemunhar uma onda inédita de reformas sociais no Reino Unido, a começar pelo "audacioso" Plano Beveridge, anunciou que o bem-estar econômico estaria acobertado pelo conjunto de direitos básicos do cidadão ${ }^{163}$.

Foi no período imediatamente posterior à Segunda Guerra, então, que os direitos sociais estiveram no seu auge. O modelo do Werfare State ${ }^{164}$, embora circunscrito à Europa ocidental e a um intervalo de 30 anos, foi a menina dos olhos

\footnotetext{
${ }^{162} \mathrm{Na}$ época de Voltaire, anterior à indústria capitalista e ao aumento exponencial do contingente do proletariado, a pobreza extrema não era uma ameaça às elites. Os pequenos distúrbios que dela decorriam poderiam ser contornados, para o filósofo, pela assistência social: "Sendo de ordinário a gatunice, o furto e o roubo crimes de pobres, e como as leis foram feitas pelos ricos, não vos parece que todos os governos, que estão nas mãos dos ricos, devem começar por tentar destruir a mendicidade, em vez de ficar à espreita da ocasião de entregá-la aos carrascos?" (VOLTAIRE. 0 preço da justiça, 2. ${ }^{a}$ ed.. Tradução de Ivone Castilho Benedetti. São Paulo: Martins Fontes, 2006, p. 9). E adiciona, em nota de rodapé: "Em todo país onde, por efeito das más leis, uma grande parte dos habitantes não tem propriedade de raiz nem capital, a sociedade é afligida por esse flagelo. É bom, sem dúvida, que haja casas onde se ofereça pão àqueles que não podem ganhar a vida, sujeitandoos a um trabalho que eles sejam capazes de realizar; mas esses asilos devem ser livres. As pessoas humanas e justas sempre se sentirão tocadas ao verem um infeliz condenado à perda da liberdade por ter pedido ajuda a outro homem. Com boas leis, os mendigos seriam raros, e o pequeno número que ainda pudesse haver não seria incômodo nem perigoso".

${ }_{163}$ Confira-se este conceito ampliado de cidadania em MARSHALL, Thomas H. Cidadania, classe social e status. Tradução de Merton Porto Gadelha. Rio de Janeiro: Zahar, 1967.

${ }_{164} \mathrm{Com}$ efeito, é um tanto limitado referir-se à noção de Estado de bem-estar ignorando-se as suas variantes. Ocorre, porém, que não será preciso, para os objetivos desta pesquisa, que nos debrucemos sobre as "nuanças" do Welfare State nas nações nórdicas, nas potências da Europa continental e nos países anglo-saxões. De qualquer maneira, pode-se conferir uma análise mais detalhada em ESPING-ANDERSEN, Gosta. As três economias políticas do welfare state. Tradução de Dinah de Abreu Azevedo. Lua Nova, São Paulo, n. 24, set. 1991.
} 
do reformismo. O chamado eurocomunismo e as outras tendências reformistas declaram o fim da era das revoluções com base nas melhorias obtidas. Ainda atualmente, não obstante o desprezo do capital por tais direitos, os adeptos do reformismo sonham com um retorno à época romântica do compromisso, aos tempos áureos, como se houvesse algum horizonte que ao menos esboçasse uma nova inflexão da burguesia nesta direção. E enquanto aguardam que o passado converta-se em futuro e lhes absolva com a razão da história, estas viúvas lamuriantes do Welfare acompanham inertes (quando não implementam) as contrarreformas encomendadas e patrocinadas pela classe capitalista, que antes dividia a mesa com elas para repartir a riqueza.

Tomando por referência a luta de classes e a reprodução econômica, dois eixos de análise incontornáveis para uma investigação marxista, entenderemos por que o Estado social foi excepcional ${ }^{165}$ na história do capitalismo (tanto no tempo como no espaço) e por que, no instante em que estava presente, não promoveu a emancipação da classe trabalhadora ${ }^{166}$. O fundamental aqui é compreender que a conquista/concessão ${ }^{167}$ de direitos sociais em grande escala só foi possível numa conjuntura absolutamente singular.

O modelo do Welfare desponta num contexto em que o pacto fordistakeynesiano se impõe como a melhor saída para um sistema que não poderia se dar

\footnotetext{
165 "A ampliação dos direitos políticos e o conteúdo material dos direitos sociais tornou o pós-Segunda Guerra Mundial o período em que a emancipação e a reivindicação da democracia econômica e social chegaram ao seu momento mais elevado. No entanto, apesar dos avanços e conquistas, o Estado social do segundo pós-guerra e os trinta anos de 'consenso keynesiano' acabaram por se revelar uma exceção na história do capitalismo. Além disso, as constituições sociais vão, desde o início, enfrentar vários obstáculos para sua concretização, sendo apenas parcialmente cumpridas" (BERCOVICI, Op. Cit., 2008, p. 321).

${ }^{66}$ Houve recortes de gênero e de nacionalidade que conspurcaram a dita universalidade do Welfare: "A experiência dos Estados de Bem-Estar Social (ou do pacto fordista), na sua plenitude, nunca se mundializou: ficou restrita a alguns países mais desenvolvidos, dentre os quais a França ocupa lugar de destaque. Nesses países, os "trinta anos gloriosos" foram especialmente marcados por avanços sociais resultantes do pacto fordista: melhoria dos salários, das condições de trabalho e de vida da classe operária. Entretanto, três segmentos ficaram fora desses avanços negociados entre 0 patronato e os sindicatos: as mulheres, os jovens e os trabalhadores migrantes. Eles nunca foram convidados à mesa de negociação e permaneceram como força de trabalho precarizada no fordismo" (THÉBAUD-MONY, Annie; DRUCK, Graça. Terceirização: a erosão dos direitos dos trabalhadores na França e no Brasil. In: DRUCK, Graça e FRANCO, Tânia (orgs.). A perda da razão social do trabalho: terceirização e precarização. São Paulo: Boitempo, 2007, p. 25).

167 Conquista e concessão de direitos são fenômenos indissociáveis numa sociedade dividida em classes, sendo orquestrados numa unidade contraditória. Um é a negação do outro, mas nenhum deles pode excluir o outro concretamente e ser a causa única dos direitos da cidadania, já que a própria luta de classes, enquanto totalidade do movimento histórico, flui por contradições insolúveis no quadro das relações de produção atuantes. Ao fim e ao cabo, no entanto, prevalece o caráter capitalista das formas sociais existentes num mundo arquitetado pelo movimento conformador do capital.
} 
ao luxo de falhar. Cessados os combates na Europa, os trabalhadores não estavam dispostos a mansamente deixar as trincheiras e voltar para as fábricas nas mesmas condições anteriores. Engajaram-se por novos patamares de existência e de civilização, ocasionando uma onda revolucionária que assombrou boa parte da burguesia mediterrânea (na França, na Itália e na Grécia ${ }^{168}$ ). Esta radicalização do movimento operário era significativamente gravosa numa conjuntura em que a União Soviética saía fortalecida politicamente do confronto com as forças do Eixo. Se a mão invisível do mercado conduzisse a sociedade burguesa a um novo 1929, a ofensiva anticapitalista poderia prosperar ainda mais (viesse ela do campo degenerado pelo burocratismo da URSS ou das forças verdadeiramente comprometidas com a revolução socialista e com o socialismo científico de Marx e Engels). O risco era elevado em demasia para as classes dominantes.

Vale frisar que o contexto era muito diferente daquele de Weimar. Em 1919, a Rússia era um alerta para as classes dominantes. Em 1945, era um sistema alternativo ao capitalismo (com todas as duas deformidades), era real e concreto, sendo que, nele, milhões de trabalhadores no mundo encontravam uma referência tangível. O impacto político da existência de um bloco "pós-capitalista" é qualitativamente superior, tanto que, com a queda do muro de Berlim e com o fim da URSS, inúmeros partidos socialistas abdicaram de seu programa e estratégia originais, pois Ihes parecia que, de fato, o mercado havia triunfado em definitivo, que a última palavra no confronto entre as classes seria dada pelo capital.

Muito bem. Diante do complexo cenário em que se encontrava, a burguesia convocou seus representantes no aparelho estatal e as direções colaboracionistas da classe trabalhadora (social-democratas e stalinistas) para negociar um regime de acumulação capaz de, a um só tempo, levantar uma economia em ruínas e assegurar que o movimento operário não ultrapassaria o horizonte do reformismo. 0 resultado, por óbvio, foi a preservação do capitalismo, embora com características pouco usuais, a começar pela notável expansão do salário indireto (que liberou os assalariados para o consumo massivo de bens duráveis, a roda mestra do fordismo).

\footnotetext{
${ }^{168}$ Nesses países, os operários pegaram em armas e depuseram os regimes (os de ocupação, na França e na Grécia, e o fascista, na Itália). Por ordem de Stálin, irmanado que estava com o imperialismo em sua política de "coexistência pacífica", os PCs orientaram as classes trabalhadoras no sentido de entregarem as armas e retomarem a normalidade da produção, agora com as compensações da social-democracia. Processos revolucionários como esses foram sistematicamente sabotados pelo stalinismo, que iniciou sua carreira de aparelho contrarrevolucionário nos anos 1930, com os Processos de Moscou e a política de Frente Popular, e que a consolidou em 1943, quando dissolveu a III Internacional para agradar Churchill e Roosevelt.
} 
No mais, foram decisivas as condições objetivas para uma inédita concertação política e econômica entre os países capitalistas, sendo o controle do fluxo de capitais a maior evidência. Isto permitiu uma sujeição das finanças à produção, quadro este que se inverteu com as desregulamentações dos anos 1970 e as políticas estadunidenses sobre o dólar e a taxa de juros. Uma experiência como essa só se daria mediante as singularidades conjunturais descritas.

O pacto entre as classes, no regime welfarista, dá-se em torno do tesouro nacional. Criou-se, deste modo, um padrão de financiamento público da economia capitalista, em que o fundo público se colocou como pressuposto tanto dos investimentos empresariais quanto da reprodução da força de trabalho, atingindo globalmente a população por meio de gastos sociais. Interessará para nossa pesquisa sobre os direitos sociais, evidentemente, a intervenção estatal na reprodução da força de trabalho. Neste aspecto, nota-se o incremento do salário indireto em comparação ao salário direto com os serviços ofertados pelo Estado ${ }^{169}$. Houve ainda um aumento do salário direto, onerando-se o capital diretamente, e não só pela via da tributação (encargos trabalhistas também integram modelo welfarista e sua rede de proteção).

É fundamental visualizar que, no Welfare, a manutenção da mão-de-obra é um objetivo perseguido obstinadamente pelo ente estatal. A reprodução da força de trabalho, indispensável à reprodução econômica geral da sociedade capitalista, é elevada à hierarquia de tarefa de Estado, sendo importante demais para ser relegada ao alvitre individual de cada capitalista e à "moderação orçamentária" de cada família operária. Comentando a generalização da seguridade social, Robert Castel identifica o sentido desta intervenção:

\footnotetext{
Uma parte do salário (do valor da força de trabalho) escapa, de agora em diante, às flutuações da economia e representa uma espécie de propriedade para a seguridade, nascida do trabalho e disponível para situações de fora do trabalho, a doença, o acidente, a velhice. O Estado social é colocado, em vista disso, no coração do dispositivo salarial ${ }^{170}$.
}

169 "O salário não é mais apenas a retribuição do trabalho calculada exatamente para garantir a reprodução do trabalhador e de sua família. Comporta uma parte - 'o salário indireto' - que constitui uma renda do trabalho para situações fora de trabalho. Estas situações são inicialmente definidas de modo negativo: a doença, o acidente, a velhice improdutiva, pálidas compensações para o trabalho quando se deveria trabalhar. Mas poderiam ser - e também serão - definidas positivamente, como a possibilidade de consumir, de se instruir, de ter lazeres..." (CASTEL, Op. Cit., 1998, p. 405).

${ }^{170}$ CASTEL, Op. Cit., 1998, p. 485 
Aqui começam alguns notórios equívocos reformistas. Francisco de Oliveira, ilustrativamente, defende que os direitos que operaram como salários indiretos funcionaram "como antimercadorias sociais, pois sua finalidade não é a de gerar lucros, nem mediante sua ação dá-se extração da mais-valia ${ }^{171 " . ~ I s t o ~ p o r q u e ~}$ as políticas intervencionistas de indução do consumo fazem com que a produção de inúmeros bens e serviços seja orientada a partir do próprio salário como parâmetro. Para o autor, haveria uma tendência à desmercantilização da força de trabalho pelo peso crescente do salário indireto (composto pelas "antimercadorias sociais") na sua reprodução. Eis a razão pela qual o fundo público atrelado aos direitos sociais seria "o antivalor, menos no sentido de que o sistema não mais produz valor, e mais no sentido de que os pressupostos da reprodução do valor contêm, em si mesmos, os elementos mais fundamentais de sua negação ${ }^{172 " . ~}$

Em contrapartida, o próprio sociólogo faz referência na introdução de sua obra a uma crítica interessante que foi endereçada à sua teoria: os recursos fiscais que integram os fundos públicos, suportes do antivalor, derivam dos tributos recolhidos da população, predominantemente composta por trabalhadores (o que se reforça nos modelos de tributação regressiva). Esta crítica, inclusive, permite questionar a alardeada natureza distributivista do Welfare, ou mesmo indagar sobre um acréscimo na exploração da classe trabalhadora em nível global. E para além deste apontamento, cabe destacar que o caráter mercantil da força de trabalho na sociedade capitalista, ou seja, sua qualidade de objeto de troca mediante paga em pecúnia, continuou intacto sob o Estado de bem-estar social. A rede de proteção que Ihe é própria, em que pese seu caráter progressista (mais ainda quando instituída mediante lutas de massa), não rompe com o estado de despossessão em que se situam os assalariados. O risco de miserabilidade diminuiu, mas o comércio da força de trabalho como mercadoria única do operário prosseguiu e aumentou com as políticas anticíclicas de pleno emprego.

Acresce ainda que, para cada trabalhador, o serviço social é um complemento à renda salarial. A prestação em que se concretiza o direito social supre alguma necessidade de reprodução da força de trabalho (educação, saúde, seguro contra a improdutividade etc.) que, de outra forma, teria que ser suprida pelo empregador.

\footnotetext{
171 OLIVEIRA, Francisco de. Os direitos do antivalor: a economia política da hegemonia imperfeita. Petrópolis: Vozes, 1998, p. 29.

172 OLIVEIRA, Op. Cit., 1998, p. 35.
} 
Quando este compra a mercadoria força de trabalho, torna-se o responsável por ela, devendo mantê-la sob cuidados, tal como o faz com seu maquinário e insumos. $\mathrm{O}$ fornecimento pelo Estado de escolas, remédios e previdência pública, nesta perspectiva, é um apoio ao capital; é a formação e manutenção da mão-de-obra num processo que se desenrola fora do mercado, mas que é feito para o mercado, é dizer, para melhor abastecer a disponibilidade de força de trabalho; é a socialização de um dos custos do capital para se engajar na produção. Na época do Welfare State, os capitalistas precisaram como nunca de um suporte generalizado deste tipo. Precisavam, como dissemos antes, alavancar uma economia arrasada e convencer operários recém-saídos dos combates de que lhes aguardava, no retorno, algo mais do que a simples exploração fabril.

Definitivamente, não há nada de anticapitalista nisto. O que há, isto sim, é a aparência ilusória de direitos feitos para o trabalhador, como se seu advento decorresse apenas da luta de classes, e não de demandas econômicas de acumulação e reprodução. $O$ direito e o Estado são instâncias da burguesia, ou melhor, do modo de produção que a promove e que estabelece sua dominação de classe. No que concerne ao conteúdo dos direitos sociais, há de se levar em conta os apontamentos de Joachim Hirsch sobre as funções do Estado (e do Estado social especificamente) e suas consequências no plano da ideologia:

\footnotetext{
A intervenção 'econômica' do Estado - da criação 'de condições materiais gerais da produção' à garantia da reprodução da força de trabalho etc. - é, conseqüentemente, parte integrante da consolidação da dominação burguesa (...). A dominação significa sempre, ao mesmo tempo, repressão de classe e garantia do processo de reprodução material. Isto se exprime, nas condições capitalistas, por uma determinação de forma específica, a saber como 'intervenção' de uma instância coercitiva, colocada fora do processo de reprodução material, instância que, sob esta forma, é essencialmente organizada de modo reativo ao movimento de acumulação do capital e às lutas de classe.

Isto significa que o modo de reação concreto, quer dizer, a maneira pela qual o Estado age para assegurar a reprodução é determinada, em seu conteúdo, pelo movimento do capital e pelas lutas de classe e, em sua forma, pela sua transposição ao nível do aparelho de Estado. O Estado defende, na aparência, o interesse de todos os membros da sociedade (e ele o faz efetivamente na medida em que estes estão interessados em sua reprodução material); assim, a intervenção do Estado representa, por exemplo, uma condição de sobrevivência para o proletariado. É isto que fornece a base material do que chamamos as ilusões do Estado-providência e de sua neutralidade. Aqui também não se trata de simples fantasias, mas de uma ideologia que encontra sua base material numa relação específica das classes oprimidas com o aparelho de Estado ${ }^{173}$.
}

${ }^{173}$ HIRSCH, Op. Cit., 1977, p. 93. 
"Nunca antes no capitalismo testemunhou-se uma repartição de rendas tão equitativa", insistirão os saudosistas, negando a acusação de capitularem a uma concepção ideológica. "Nunca os trabalhadores vivenciaram condições econômicas tão favoráveis", bradarão. Deveriam, entretanto, dizer-nos como isto ocorreu, mencionando, de começo, o crescimento econômico anormal do período ${ }^{174}$. Se o tão estimado capitalismo dos reformistas crescesse mundialmente a taxas de 5 a $6 \%$, um observador otimista, que desconhecesse a natureza expansionista do capital, que ignorasse a tresloucada valorização de valor em que está baseado, até poderia admitir, por hipótese, que as classes dominantes, um dia, se resignariam a taxas de lucro mais "moderadas" e, por conseguinte, a uma repartição do bolo nos moldes welfaristas. Afinal, é menos oneroso fazer concessões nos períodos de prosperidade do que nos períodos de estagnação.

Infelizmente para o nosso observador otimista, o capitalismo não é assim. 0 crescimento econômico não é algo simples nesse sistema, sendo que, hodiernamente, as economias nacionais, em regra, esbarram em soberbas dificuldades para ao menos se aproximarem da marca de $3 \%$, considerada saudável pela imprensa financeira ${ }^{175}$.

Crescer significa realizar um movimento de reprodução ampliada, quer dizer, de reposição e expansão dos fatores de produção, empregando-se o excedente apanhado para a obtenção de novo excedente em áreas e nichos onde o potencial de exploração econômica ainda não se esgotou, numa cadeia de acumulação de capital que se pretende ininterrupta. À medida que o capitalismo cresce, maior é o volume de capitais que se exige movimentar para manter e ampliar a acumulação. David Harvey explica como a mundialização do capital faz do crescimento um trabalho de Hércules:

\footnotetext{
174 "O que parecia evidente até o começo da década de 70 revela agora a perturbadora singularidade de um período inédito na história da humanidade, ou pelo menos naquela dos países industrializados. Assiste-se então na França, entre 1953 e 1975 mais ou menos, com taxas anuais de crescimento de 5 a $6 \%$, praticamente à triplicação da produtividade, do consumo e da renda salarial" (CASTEL, Op. Cit., 1998, p. 479).

175 "Ao longo da história do capitalismo, a taxa composta de crescimento real foi de cerca de 2,25\%/ ao ano (negativa em 1930 e muito maior - cerca de 5\% - no período de 1945 a 1973). O consenso atual entre os economistas e na imprensa financeira é que uma economia 'saudável' do capitalismo, em que a maioria dos capitalistas obtém um lucro razoável, expande-se em $3 \%$ ao ano. Quando se cresce menos do que isso, a economia é considerada lenta. Quando se obtém abaixo de $1 \%$, a linguagem de recessão e a crise estouram (muitos capitalistas não têm lucro)" (HARVEY, David. 0 enigma do capital: e as crises do capitalismo. Tradução de João Alexandre Peschanski. São Paulo: Boitempo, 2011, p. 30).
} 
Quando o capitalismo era composto de atividades dentro um raio de cem quilômetros em torno de Manchester e Birmingham, na Inglaterra, e alguns outros pontos centrais em 1750, a acumulação de capital a uma taxa composta de $3 \%$ a um nível aparentemente infinito não representava um grande problema. Mas agora pense no crescimento composto infinito não só em relação a tudo o que está acontecendo na América do Norte, Oceania e Europa, mas também no Leste e Sudeste da Ásia, assim como em grande parte da Índia e do Oriente Médio, América Latina e áreas significantes da África. A tarefa de manter o capitalismo crescendo a esse ritmo composto é assustadora $^{176}$.

Se os saudosistas do Welfare State esperam uma nova onda de crescimento espetacular, é prudente que aguardem sentados. E ainda que ela caísse do céu, apenas neste intervalo sua aspiração de capitalismo edulcorado teria alguma viabilidade, caso considerássemos unilateralmente o fator em questão.

Os chamados "Anos dourados" da economia capitalista (1945-1973) só se abriram depois de uma crise catastrófica em 1929, de uma longa depressão ao longo dos anos 1930 e de uma guerra global que dizimou força de trabalho e meios de produção em escala sem precedentes. Os capitais que não encontravam aplicação lucrativa na etapa anterior foram escoados para reerguer os países dos escombros (embora em parte considerável já houvesse sido absorvida pelas obras de infra-estrutura e, sobretudo, pela indústria armamentista). A reconstrução foi um sucesso e, como já foi visto, teve como custo uma nova sobreacumulação de capitais, que desembocou na crise dos anos 1970.

Existe uma tendência no sistema capitalista no sentido de se gerar "excedentes de capital (em termos de mercadoria, moeda e capacidade produtiva) e excedentes de força de trabalho lado a lado, sem que haja aparentemente uma maneira de conjugá-los lucrativamente ${ }^{177 "}$. Marx vislumbrou o fato:

Com a queda da taxa de lucro, aumenta o mínimo de capital que tem de estar nas mãos de cada capitalista para o emprego produtivo de trabalho; 0 mínimo exigido para se explorar o trabalho em geral e ainda para que o tempo de trabalho aplicado seja o necessário para a produção das mercadorias, não ultrapassando a média do tempo de trabalho socialmente necessário para produzi-las. Ao mesmo tempo, aumenta a concentração, pois, além de certos limites, capital grande com pequena taxa de lucro

\footnotetext{
${ }^{176}$ HARVEY, Op. Cit., 2011, p. 31.

177 HARVEY, David. O novo imperialismo, 3. a ed. Tradução de Adail Sobral e Maria Stela Gonçalves. São Paulo: Edições Loyola, 2009, p. 78. As razões para a sobreacumulação podem ser as seguintes: "profit squeeze" (o preço da força de trabalho se eleva com o aumento da demanda), problemas de demanda efetiva (quando os lucros não realizam o valor investido) ou a própria lei tendencial da queda da taxa de lucro.
} 
acumula-se mais rapidamente que capital pequeno com taxa elevada. A certo nível, essa concentração crescente do capital, por sua vez, acarreta nova queda da taxa de lucro. A massa dos pequenos capitais dispersos é assim empurrada para as peripécias da especulação, das manobras fraudulentas com créditos e ações, das crises. A chamada pletora de capital é sempre e essencialmente a de capitais cujo montante não compensa a queda da taxa de lucro - e assim vão constantemente se formando os novos viveiros de capital - ou a pletora que, sob a forma de crédito, põe esses capitais, incapazes de ação autônoma, à disposição dos condutores dos grandes negócios. Essa pletora de capitais nasce das mesmas circunstâncias que provocam superpopulação relativa, sendo, portanto, fenômeno que a completa, embora ambas estejam em pólos opostos, de um lado capital desempregado e, do outro, população trabalhadora desempregada $^{178}$.

O mecanismo sistêmico de solução dos excessos de capital é a crise. Harvey sugere que as crises "assumem um papel fundamental na geografia histórica do capitalismo como 'racionalizadores irracionais' de um sistema inerentemente contraditório ${ }^{179, "}$. Valério Arcary vai além, localizando nestas intempéries uma oportunidade de se elevar o nível de espoliação sobre a classe operária:

O capitalismo precisa das crises. As crises são o processo de seleção dos capitais mais rentáveis, de eliminação das companhias obsoletas, de resolução temporária da competição entre os Estados no sistema internacional e, sobretudo, de medição de forças com o proletariado. A hora da crise é a hora em que o capital e trabalho são convocados frente a frente para um ajuste de contas. Em cada crise, se a classe trabalhadora não impuser resistência, o capital descarregará sobre suas costas o preço do ajuste. Apesar do imenso sofrimento humano sob o capitalismo, as crises têm um efeito regenerador do sistema e regulador das relações entre as classes e entre os Estados: é preciso que a concorrência entre as empresas e entre as nações alcance o paroxismo da ruína dos menos rentáveis e dos mais débeis para que aconteça a concentração de capitais; é preciso que o desemprego em massa pressione o salário médio para baixo, para que os lucros se recuperem ${ }^{180}$.

O projeto de um capitalismo reformado, atado a um rol amplo de direitos sociais que assegure alguma distribuição de riquezas ${ }^{181}$, ignora todos os obstáculos

${ }^{178}$ C., III, IV, pp. 329-330.

179 HARVEY, Op. Cit., 2011, pp. 99-100.

180 ARCARY, Valério. O encontro da revolução com a história: socialismo como projeto na tradição marxista. São Paulo: Instituto José Luís e Rosa Sundermann; Xamã, 2006, pp. 52-53.

${ }_{181}$ O problema, para os social-democratas, está na distribuição da riqueza, e nunca na maneira como ela é produzida. Eleutério Prado capta as raízes históricas desta ideologização: "O liberalismo social foi a ideologia apropriada ao período da grande indústria, quando sobrevieram as crises do final do século XIX e quando o capitalismo tornou-se monopolista. Na história do pensamento econômico, entretanto, ele aparece já nas teses de John Stuart Mill. Segundo esse autor, os fenômenos da produção estão subordinados às leis naturais, caracterizadas por um determinismo que não pode ser modificado pelo homem. A repartição, entretanto, pode ser objeto de legislação humana e esta pode promover uma melhor conciliação do interesse geral com os interesses privados. A essência do capitalismo não aparece nessa visão política como exploração, mas como má-repartição da renda e 
que citamos, e por isso esteve fadado, desde sempre, a ser de curta duração. A estruturação econômica da sociedade burguesa e sua dinâmica de crises assim exigem. O conjunto de direitos do Welfare só foi admitido em sua extensão enquanto mostrou-se compatível e mesmo conveniente ao padrão de acumulação. Com a guinada financeira, o consumo de massa foi deixado de lado na lista de tarefas prioritárias do Estado. Além disso, a circunscrição espacial da rede welfarista sempre foi extremamente limitada, e não por acaso. $O$ desenvolvimento desigual e combinado da economia capitalista permitiu que empresas estadunidenses, europeias e japonesas arcassem com encargos sociais e trabalhistas consideráveis em suas terras e, ao mesmo tempo, se esbaldassem nas nações periféricas, com seus salários ínfimos, seus recursos naturais abundantes e seus governos próimperialismo.

A derrocada do Estado social, em concreto, também remete à financeirização da economia capitalista, e é chegado o momento de aprofundar esta ideia. Ela revela a natureza íntima do capital, e é por desconhecê-la ou deliberadamente ignorá-la que o reformismo apresenta à humanidade uma proposta insustentável.

A financeirização da economia mundial é um fenômeno que se inicia nos anos 70, caracterizando-se como um dos refúgios onde os capitais sobreacumulados da "Era de Ouro" buscaram abrigo (os outros escoadouros foram a reestruturação produtiva, as políticas de cunho neoliberal e a restauração capitalista na China e no Leste Europeu). Esta financeirização, impulsionada pelo fim do padrão de Bretton Woods e pela desregulamentação dos mercados financeiros, inaugura um momento histórico em que a lógica financeira assume o controle da reprodução econômica, sobretudo no que tange à valorização. De acordo com Leda Maria Paulani, inclusive,

'“Dominância financeira da valorização' afigura-se um termo mais adequado
do que 'dominância da valorização financeira', pois enquanto o último
refere-se a momentos ou fases na história do capitalismo em que a
valorização rentista se exacerba e se sobrepõe à valorização produtiva de
um modo insustentável no longo prazo, o primeiro diz respeito à etapa
corrente do capitalismo, na qual a importância e a dimensão dos capitais e
da valorização financeira, combinados à peculiar forma assumida pelo
sistema monetário internacional, fazem com que a lógica da valorização
financeira contamine também a esfera produtiva, gerando um novo modo de
regulação adequado ao regime de acumulação financeira. As mudanças
operadas pelo toyotismo vão nessa direção. A chamada 'flexibilização do
trabalho', por exemplo, permite, entre outros: utilizar mais intensamente o

da riqueza, como diferença e desigualdade que o reformismo pode modificar" (PRADO, Eleutério. Desmedida do valor: crítica da pós-grande indústria. São Paulo: Xamã, 2005, p. 130) 
valor de uso da força de trabalho; repartir com o trabalho os riscos do capital, flexibilizando o próprio capital; em conjunto com a customização da produção, reduzir ao mínimo o custo de carregamento de estoques de matérias-primas e bens intermediários (que se torna um desperdício imperdoável num contexto de taxas de juros positivas e elevadas). Todas essas mudanças têm que ver com o contexto no qual hoje deve se dar a valorização produtiva, qual seja: o contexto rentista e curto-prazista da valorização financeira ${ }^{182, "}$.

O aprofundamento da financeirização foi tamanho que não coube no interior das fronteiras da rede bancária. Houve uma "desintermediação" que permitiu aos conglomerados capitalistas (e fundos de pensão) colocar títulos diretamente nos mercados financeiros. Rumou-se para uma hipertrofia da esfera destas operações, a ponto de hoje se constatar uma situação em que o conjunto dos ativos em circulação equivale a quatro vezes o valor do PIB mundial. A rentabilidade célere e flexível atrai os capitais, de sorte que uma empresa como a Sadia, antes de quebrar, aplicava mais da metade de seus investimentos não na produção de alimentos, e sim na especulação com o mercado de câmbio. A empresa estadunidense Enron, por sua vez, utilizava seus lucros para criar empresas-fantasmas que comprassem suas próprias ações, sinalizando para os investidores que seus ativos eram dignos de confiança. A descoberta gerou um escândalo e a subsequente falência da companhia, com todos os imagináveis desdobramentos econômicos e sociais. No caso da Enron, houve ainda um vasto prejuízo nos direitos de pensão, configurando um dano direto aos trabalhadores. Aliás, os fundos de pensão protagonizam diversos episódios em que o risco da atividade financeira se transfere parcial ou integralmente para os segurados. Eis o traço distintivo dos modernos sistemas previdenciários privados de capitalização, que vêm substituindo os sistemas públicos de repartição simples com matriz welfarista.

Com a financeirização, o capital fictício se propaga em ampla escala, e o mercado acionário ilustra com clareza esta realidade. Os dividendos são uma fração da mais-valia que remunera os acionistas ${ }^{183}$ que investiram, e não há nada de

\footnotetext{
182 PAULANI, Leda M. Brasil Delivery: servidão financeira e estado de emergência econômico. São Paulo: Boitempo, 2008, pp. 46-47.

${ }^{183}$ É interessante pontuar que os acionistas, sob o capitalismo financeirizado, foram sacralizados pela filosofia do "shareholder value". Segundo Kurz, "O primeiro mandamento dessa nova ética filosófica da administração prescreve: 'Não terá nenhum outro Deus senão teu acionista'. 'Shareholder value' significa portanto uma raivosa defesa dos interesses acionários por parte da política comercial das sociedades empresariais. (...) A vida humana como um todo, um conjunto dos compromissos sociais, o restante da cultura e até mesmo os interesses da burocracia estatal devem subordinar-se à 'produção de rendas atraentes para os acionistas' e, caso necessário, ser imolados nesse altar. A
} 
especulativo nesta atividade. Ocorre que a compra de ações, na imensa maioria das vezes, não tem por objetivo financiar algum empreendimento produtivo. Quer-se apenas a alienar o ativo a preço mais caro do que o de compra conforme as expectativas, independentemente do desempenho econômico real, sendo que é exatamente esta a raiz da formação de bolhas. Formam-se, então, montanhas de capital fictício, que drenam o produto social até que uma grande desvalorização de ativos desnude toda a farsa ${ }^{184}$.

Ainda com relação ao capital fictício, deve-se ter em vista o fator crucial do endividamento e da atuação dos bancos:

\begin{abstract}
Os bancos normalmente emprestam, digamos, três vezes o valor de seus depósitos sob a lógica de que os devedores nunca deixarão de pagar ao mesmo tempo. Quando um banco se defronta com muita inadimplência, certamente tem de fechar suas portas porque nunca vai ter dinheiro suficiente em mãos para cobrir suas obrigações. A partir da década de 1990, os bancos elevaram a razão dívida-capital frequentemente concedendo empréstimos uns aos outros. O setor bancário tornou-se mais endividado do que qualquer outro da economia. Até 2005, a razão chegou a estar tão alta como 30 para 1. Não admira que o mundo parecesse estar inundado com excesso de liquidez. Excedentes de capital fictício criados dentro do sistema bancário absorveram o excedente! $!^{185}$.
\end{abstract}

Não obstante sua destrutividade, o modelo segue firme, e graças ao respaldo estatal. Às quebradeiras, segue-se a intervenção socorrista do Estado, valendo-se do tesouro nacional para cobrir os rombos financeiros privados. E como não se pode simplesmente imprimir moeda (as consequências deletérias são inevitáveis, a começar pela inflação), os governos realizam drásticos ajustes fiscais (leia-se: cortes na área social) para sinalizar ao mercado que são "responsáveis" em suas políticas, que merecem receber novos empréstimos. Assim, apazigua-se temporariamente a intempérie no mundo das finanças, enquanto a classe trabalhadora se vê fustigada por medidas de arrocho salarial (destacadamente no funcionalismo), restrições a direitos previdenciários, desmonte nos serviços públicos etc. E numa economia de escopo como aquela oferecida pela acumulação flexível, em franco contraste com a economia de escala fordista, o consumo de massas não está na ordem do dia. A

humanidade, a par de seu ambiente natural, é mantida como refém dos grandes acionistas privados e institucionais" (KURZ, Op. Cit., 1998, pp. 216-217).

184 "A esfera financeira alimenta-se da riqueza criada pelo investimento e pela mobilização de uma força de trabalho de múltiplos níveis de qualificação. Ela mesma não cria nada. Representa a arena onde se joga um jogo de soma zero: o que alguém ganha dentro do circuito fechado do sistema financeiro, outro perde" (CHESNAIS, Op. Cit., 1996, p. 241).

${ }^{185}$ HARVEY, Op. Cit., 2011, p. 33. 
classe trabalhadora não é mais a destinatária por excelência da miríade de mercadorias lançadas à esfera mercantil, razão pela qual o salário indireto corporificado nos direitos sociais torna-se relativamente supérfluo. O consumismo das classes médias e o luxo das elites mantêm aquecida a demanda efetiva (parece completamente desarrazoada, ao menos atualmente, a noção de que o capitalismo padece de crises de subconsumo). Além do quê, o instrumento econômico mais atrativo de fomento ao consumo num contexto de financeirização, invariavelmente, é o crédito, que ocupa o lugar dos aumentos reais de salário e dos serviços públicos.

Que fique claro: uma cota mínima de direitos sociais é necessária ao capitalismo moderno, no sentido de uma socialização mínima dos custos com a força de trabalho. O segredo do neoliberalismo está em reduzir draconianamente este mínimo e em adequá-lo aos padrões da acumulação operantes.

O caso da Previdência social é exemplar: o regime de capitalização substitui o de repartição simples por expressar os interesses da valorização financeira e da acumulação flexível ${ }^{186}$. Libera-se campo para os fundos de pensão privados e para as aventuras especulativas, amparadas na avareza para entregar benefícios, quer dizer, no reforço do vínculo entre contribuição e benefício. Os recursos estatais são direcionados à rolagem da dívida pública em caráter prioritário, atendendo servilmente à ânsia insaciável do capital financeiro. A solidariedade intergeracional é abandonada. Deixa a cena o objetivo da segurança econômica numa sociedade de consumo massivo e entra o objetivo do lucro fácil, rápido e privado (além de arriscado ao extremo). No Welfare State, ao contrário, o regime de repartição simples era mais conveniente para uma economia em que a renda dos assalariados possuía um peso considerável no PIB. Cabia ao Estado organizar diretamente este arranjo.

As investidas neoliberais contra os direitos humanos de segunda dimensão ensejam dois equívocos muito recorrentes. Um é o reforço à tese de que esses direitos seriam anticapitalistas, ignorando-se completamente o fato de que só no capitalismo surgem os direitos sociais. Em outras formações sócio-econômicas, houve mecanismos estatais de reprodução de mão-de-obra, dir-se-á. Mas eles eram demasiado reduzidos em sua amplitude e complexidade. Nada seria mais

${ }^{186}$ Maiores informações sobre o assunto podem ser conferidas em PAULANI, Leda M. Seguridade social, regimes previdenciários e padrão de acumulação: uma nota teórica e uma observação sobre o Brasil. In: FAGNANI, Eduardo et alii. Previdência social: como incluir os excluídos. São Paulo: LTR, 2008. 
disparatado do que querer comparar o pacto fordista-keynesiano que financiou o Estado social com, por exemplo, o simplório sistema de armazenagem e distribuição de grãos no império romano. E ainda que fosse admissível a comparação, faltava em Roma, decisivamente, o formato jurídico na entrega do "benefício". O arrimo estatal à manutenção da mão-de-obra não se exercia mediante a forma jurídica.

O segundo equívoco está em atribuir a "culpa" das preferências do Estado nas suas despesas tão somente ao capital financeiro, e não ao modo de produção capitalista em si. A oposição entre capital produtivo e capital financeiro é fonte de inconcebíveis deslizes conceituais, e por ela passa a jornada épica dos socialdemocratas e dos stalinistas em busca de uma "dissidência progressista" da classe capitalista. Com efeito, a mítica fração progressista da burguesia foi o Santo Graal de boa parte da esquerda no século XX.

Em face do exacerbado domínio das finanças, do rentismo e dos desvarios do capital fictício, a resposta imediata do reformismo é sonhar com o status quo ante. $O$ sistema teria sido belo e aconchegante, até que uma ardilosa conspiração de aproveitadores resolveu desacorrentar a besta das finanças. $O$ capital financeiro seria uma forma insegura e parasitária, enquanto que o capital produtivo, como seu próprio nome parece sugerir, seria útil e benévolo. Uma nostalgia do fordismokeynesianismo faz supor que a chave para a salvação do mundo é recompor o modelo anterior para que a marcha do Welfare retome o rumo interrompido.

Contra os suspiros desta canção romântica, apresentamos, em outra ocasião, os argumentos reproduzidos abaixo:

Em verdade, cumpre esclarecer o seguinte: capital é sempre capital, nunca deixa de ser valor que busca se valorizar. As diferenças dos espaços de valorização trazem consigo suas peculiaridades, mas a essência da persecução do lucro permanece. Aliás, a finança é inerente ao capitalismo, é um corolário da produção capitalista (vide a imprescindibilidade de um sistema de crédito, por exemplo). Portanto, a ideia de um capitalismo pautado puramente pela produção é puramente cerebrina, e pressupõe a negação do sistema em si, pois a possibilidade do dinheiro se converter em capital já aponta para a forma financeira. Some-se a isto o caráter do capitalismo: o que importa é a expansão do valor, e não a produção de coisas úteis. O produto é um mero veículo do valor na produção capitalista, é a carcaça necessária ao consumo que permite a realização do lucro, único objetivo do empresário. Neste sentido, "burlar" a produção apresentase como um "atalho" extremamente desejável para os detentores do capital. Saltar de D - M - D' para D - D' é a tendência do capital em si, é o movimento que corresponde à sua íntima natureza de processo de valorização do valor e de maximização do lucro. E se o financista merece o anátema por extrair riqueza da produção como um todo, melhor juízo não merece o industrial, que se alimenta do trabalho alheio. 
Ora, sendo o Estado o conjunto dos aparelhos repressivos, ideológicos e econômicos a serviço da reprodução do capital e da sociedade burguesa como um todo, o que lhe cabe, essencialmente, é tutelar o processo de valorização. Se esta valorização é produtiva ou financeira, real ou fictícia, pouco importa. Não há que se imaginar, assim, um Estado paladino da indústria que caminha na contramão do próprio movimento do valor, que se choca com a tendência de um capital que enfim encontrou a liberdade que 0 faz corresponder a seu conceito de modo mais exato e direto ${ }^{187}$.

Abdicando do conceito marxista de capital, o reformismo enxerga na financeirização e na guinada neoliberal que lhe corresponde apenas um refluxo político. Ignora que o movimento de valorização do valor no capitalismo aspira ao infinito, encontrando no Estado o mais apto instrumento para a manutenção e a expansão dos lucros. O que está em curso é muito mais que um refluxo: é a realização plena de uma formação social governada pelo valor de troca das mercadorias em detrimento do seu valor de uso. O capitalismo sempre caminhou para isso. Eis o obstáculo estrutural a qualquer programa que se restrinja a reformas sociais, quer para implementá-las, quer para simplesmente conservá-las em longo prazo.

A perspectiva de um capitalismo sujeito a rédeas que neguem o seu fluxo inerente é o pressuposto insustentável dos apologistas da social-democracia e um frágil sustentáculo dos que concebem os direitos de segunda dimensão como oriundos de um aperfeiçoamento da dignidade humana, de um reconhecimento posterior de que este atributo comporta diferentes aspectos. O capital não existe para que as pessoas possam comer, habitar, se instruir e assegurar seu futuro. $\mathrm{Na}$ sociedade capitalista, são as pessoas que existem para abastecer o capital com sua necessidade de absorver trabalho vivo. Neste diapasão, Mészáros disserta sobre a feição totalitária e incontrolável desta forma social:

A razão principal por que este sistema forçosamente escapa a um
significativo grau de controle humano é precisamente o fato de ter, ele
próprio, surgido no curso da história como uma poderosa - na verdade, até
o presente, de longe a mais poderosa - estrutura "totalizadora" de controle
à qual tudo o mais, inclusive seres humanos, deve-se ajustar, e assim
provar sua 'viabilidade produtiva', ou perecer, caso não consiga se adaptar.
Não se pode imaginar um sistema de controle mais inexoravelmente
absorvente - e, neste importante sentido, 'totalitário' - do que o sistema do
capital globalmente dominante, que sujeita cegamente aos mesmos

187 BIONDI, Pablo. Acumulação por espoliação e direitos sociais: crítica do reformismo. Revista Crítica do Direito, n. 1, v. 13, jul. 2011. Disponível em: <http://www.criticadodireito.com.br/edicaoatual-numero-1-volume-13/acumulacao-por-espoliacao-e-direitos-sociais-critica-do-reformismo>.

Acesso em: 31 dez. 2011. 
imperativos a questão da saúde e a do comércio, a educação e a agricultura, a arte e a indústria manufatureira, que implacavelmente sobrepõe a tudo seus próprios critérios de viabilidade, desde as menores unidades de seu 'microcosmo' até as mais gigantescas empresas transnacionais, desde as mais íntimas relações pessoais aos mais complexos processos de tomada de decisão dos vastos monopólios industriais, sempre a favor dos fortes e contra os fracos ${ }^{188}$.

Uma demonstração mais concreta da posição que estamos advogando se dará a seguir.

\title{
4.4. Um exemplo prático: o direito do trabalho
}

O ramo justrabalhista oferece-nos uma nítida comprovação de como um direito social, aparentemente feito sob encomenda para os trabalhadores, está sujeito às diretrizes do capital e conspira para o favorecimento do modo de produção capitalista (e para a perpetuação das iniquidades que afligem a classe obreira).

Seja numa fábrica chinesa com condições de trabalho aviltantes, seja numa fábrica norueguesa com normas rígidas de segurança, tanto numa situação como na outra se realiza a extração de mais-valia em favor do capital. O direito do trabalho, enquanto forma contratual que acoberta esta operação, não impede a coleta do excedente produzido. Muito ao contrário, ele a viabiliza quando nivela explorador e explorado à condição de contratantes, de sujeitos de direito entrelaçados numa inocente relação jurídica.

Este nivelamento realiza-se na forma de uma intervenção do Estado no conflito capital-trabalho. A dimensão jurídica disto é esclarecida por Carlos Simões:

\begin{abstract}
O direito do trabalho emergiu então como intervenção do Estado nas relações entre capital e trabalho, com a finalidade de recompor a eqüidade, como direito dos empregados em contrapartida à superioridade econômica dos empregadores. Intervém contra a natural depredação do estoque, elevando a relação entre oferta e procura ao nível da respectiva acumulação capitalista, com a pretensão de compensar a inferioridade econômica dos trabalhadores por meio de normas de interesse público com sentido protecionista. A doutrina burguesa, diante do acirramento da luta operária, passou então a reconhecer os trabalhadores como classe 'pobre', uma espécie de sujeito jurídico caído em desgraça. A 'questão social' foi incorporada à teoria pela negação da luta de classes e da distinção qualitativa do operariado em relação aos capitalistas - reduzidos a diferenças de grau de riqueza. A doutrina passou então a elaborar o instituto do trabalhador como empregado hipossuficiente e individual ${ }^{189}$.
\end{abstract}

\footnotetext{
${ }^{188}$ MÉSZÁROS, Op. Cit., 2002, p. 96.

189 SIMÕES, Carlos Jorge Martins. Direito do trabalho e modo de produção capitalista. São Paulo: Símbolo, 1979, p. 228.
} 
O empregado, em sua relação jurídica com o empregador, é um sujeito de direito decaído, fragilizado pela desequilibrada distribuição de renda (o papel de cada contratante na produção é ignorado), cabendo ao direito, na sua incidência providencial, compensar a desigualdade. A igualdade perdida do código civil e das declarações de direitos humanos de primeira dimensão é enfim restaurada sob o marco da questão social. Assim, os homens se diferenciam apenas por gradações nos seus rendimentos. A equivalência contratual entre membros de classes estruturalmente antagônicas segue firme.

A origem intervencionista do direito do trabalho leva a crer que ele está lastreado numa atuação socorrista do Estado em favor dos trabalhadores, afastando-se $o$ individualismo e o contratualismo liberais. Nada mais falso. $O$ que se constata na realidade é que a providência estatal é inteiramente pautada pelas condições e exigências do contrato de trabalho, e isto é perceptível no direito material e no direito processual:

\begin{abstract}
O direito substantivo (CLT, códigos do trabalho) desenvolve-se claramente sob a estrutura das cláusulas do contrato de trabalho: identificação do empregado (Carteira de Trabalho, anotações, registros na empresa), horário de trabalho (horas normais, extras, diurnas, noturnas, extra-diurnas e extranoturnas, horários especiais), salário (salário-mínimo, in natura, critérios de remuneração - alteração, suspensão e interrupção contratual - prazo de pagamento, estabilidade, força-maior, aviso prévio, rescisão da relação de emprego), condições de trabalho (normas de segurança e higiene do trabalho), férias e normas especiais (mulheres, menores, bancários, empregados em telecomunicações, operadores cinematográficos, ferroviários, marinheiros, empregados em frigoríficos, estivadores, mineiros, jornalistas, professores e químicos). E o direito adjetivo mantém correspondência com a estrutura contratual (embora a relação processual não seja, em si mesma, contratual) instituindo-a como relação jurídica processual por meio da inclusão de um terceiro elemento, o juiz como razão objetiva, imparcial e estática. Sob a iniciativa, autonomia e responsabilidade dos contratantes em conflito, elevados a partes litigantes com faculdades e deveres processuais, o juiz atua sob o princípio basilar do contraditório, reconstituindo fenomenologicamente os fatos do conflito com vistas a recompor, na relação privada, a situação de equivalência e reciprocidade original $^{190}$
\end{abstract}

E nem se diga que o direito coletivo do trabalho escapa às limitações da forma jurídica. $O$ individualismo jurídico está enraizado em cada categoria deste ramo do direito, e imaginar que a dita "autonomia privada coletiva" rompe com esta lógica afigura-se como ledo engano. Trata-se, isto sim, de uma transposição da

${ }^{190}$ SIMÕES, Op. Cit., 1979, p. 187. 
forma contratual para o plano sindical, a exemplo do que ocorreu no sistema de Estados com o direito internacional. As liberdades coletivas não são mais do que liberdades individuais do sujeito de direito exercidas coletivamente ${ }^{191}$.

A negociação coletiva está inteiramente embebida numa estrutura contratual. É a contratualização do conflito, é a juridificação da luta econômica entre as classes, passível até de coerção judicial, quando se traduz numa lide entre suscitante e suscitado. Empregadores e empregados enviam representantes para negociar sobre remuneração e condições de trabalho, nada mais. No dissídio, não se admite por em causa nada que não se comunique diretamente com os contratos de trabalho. Só o que se autoriza, ou melhor, se exige, é a composição em comum de normas jurídicas, a coautoria de compromissos firmados mediante relações jurídicas. Começaram aí as panaceias da concertação social e do pluralismo jurídico.

Nem a greve, o ápice do conflito trabalhista, foge às limitações do direito. Supiot nota que "la grève se presente comme un choix ouvert aux individus, choix qui implique la liberte de ne pas faire greve, c'est-à-dire la liberte du travail ${ }^{192, " . ~ E l a ~ e ́ ~}$ ainda uma liberdade essencialmente individual. Pela óptica do direito, não só o empregador é digno de proteção contra piquetes. O fura-greves também o é.

No mais, o enquadramento jurídico do movimento paredista confidencia a quem serve o direito do trabalho. Suas referências são o contrato e a propriedade privada. Para Bernard Edelman, ele é contratualizado pelo direito. Nesta formatação, "la grève est licite dans la mesure du contrat de travail; là où il y a abus contractuel, il y a grève abusive. Autrement dit, lorsque la grève devient extracontractuelle elle devient, par voie de conséquence abusive, illicite ou illégale ${ }^{193, "}$.

Faltou apenas dizer: "selvagem". O contrato é a medida da civilização burguesa. Uma greve que não observa seus parâmetros carece dos rudimentos de

191 Até mesmo um autor não marxista como Alain Supiot foi capaz de perceber, ainda que com diversas limitações e contradições, o elemento de continuidade da forma jurídica. Para ele, a análise das liberdades coletivas consagradas pelo direito do trabalho demonstra que para "la liberté syndicale, du droit de greve ou du droit à la négociation collective, leur structure juridique est toujours la même, il s'agit de libertes individuelles d'agir collectivement' (SUPIOT, Alain. Critique du droit du travail, 2.. ed. Paris: Quadrige/PUF, 2007, p. 140). Traduzindo: para "a liberdade sindical, de direito de greve ou de direito à negociação coletiva, sua estrutura jurídica é sempre a mesma, tratam-se de liberdades individuais de agir coletivamente".

192 SUPIOT, Op. Cit., 2007, p. 142. Em nossa língua: "A greve apresenta-se como uma escolha aberta aos indivíduos, escolha que implica a liberdade de não fazer greve, é dizer, a liberdade de trabalho".

${ }^{193}$ EDELMAN, Bernard. La légalisation de la classe ouvrière, t. I: l'entreprise. Paris: Christian Bourgois, 1978, p. 38. Em vernáculo: "a greve é lícita na medida do contrato de trabalho; lá onde houver abuso contratual, há greve abusiva. Dito de outro modo, quando a greve se torna extracontratual, ela se torna, por via de consequência, abusiva, ilícita ou ilegal". 
civilidade, assemelhando-se à barbárie. Eis aí aonde chega a grandiosa liberdade coletiva no capitalismo!

A greve é um direito e, como qualquer direito, encontra barreira na liberdade do vizinho, com quem dialoga apenas pela mediação contratual de uma relação jurídica. Cada indivíduo-átomo usufrui egoisticamente sua liberdade, e encontra no outro um obstáculo para sua realização. Ao restringir a oferta de sua mercadoria força de trabalho, os trabalhadores devem respeitar os direitos de seus adversários. Devem lutar com "boa-fé", comunicando seus atos com antecedência e respeitando a propriedade privada. Ocupar o local de trabalho, por exemplo, é prática proibida, pois atenta contra a esfera individual de propriedade do empregador e extrapola 0 continente das relações jurídicas.

Finalmente, a forma jurídica interdita a política nas atividades paredistas. Sob o capitalismo, em virtude de suas feições mercantis, a economia e a política estão apartadas (a apropriação do excedente é feita por uma troca), cabendo ao direito (particularmente ao Poder Judiciário) cuidar para que a luta operária encerre-se em reivindicações puramente econômicas. Edelman capta esta circunstância a partir do tratamento que os tribunais dão às greves políticas da classe operária, pressupondo a distinção entre os domínios do profissional e do político como um desdobramento da distinção entre sociedade civil e Estado:

\begin{abstract}
Si, en effet, le travail est profissionnel, il ressortit à l'évidence à la sphere économique, aux intérêts privés, au droit privé; et tout le monde sait qu'au "privé" on oppose le "public" ou le général, au singulier l'universel... Bref, en qualifiant le travail de "profissionel", on le range du côté de l'économique: à l'Homme (le travailleur) l'économique, au citoyen la participation politique. Et la bourgeoisie pourra alors sereinement affirmer que la politique s'arrête aux portes de l'usine; elle pourra dénier à la classe ouvrière la seule pratique de classe qui lui soit propre - la greve - puisqu'elle esta la seule pratique ou la classe ouvrière s'organise elle-même, et pour elle-même, sur lês lieux de la production.

Ainsi, par ce simple qualificativ, les tribunaux vont cantonner les luttes ouvrières dans la legalité, entendez dans la legalité bourgeoise, c'est-à-dire dans le "non-politique".

Que nous revele alors la grève politique? La lutte de classe, sous la forme d'une lutte irréductible entre deux organisation de pouvoir: d'un côté l'organisation politique bourgeoise, dominante, triomphante, avec sés appareils constitués (l'appareil d'Etat); de l'autre côté l'organisation politique prolétarienne dominée, contaminée, sans cesse réduite à la lutte 'économique', à qui l'on nie tout caractere 'politique ${ }^{, 194}$.
\end{abstract}

194 EDELMAN, Op. Cit., 1978, pp. 53-54. Em língua vernácula: "Se, com efeito, o trabalho é profissional, ele sobressai, evidentemente, à esfera econômica, aos interesses privados, ao direito privado; e todo mundo sabe que ao 'privado' se opõe o 'público' ou o geral, ao singular o universal... Em suma, qualificando-se o trabalho de 'profissional', ele é colocado do lado do econômico: ao 
Ainda no ramo justrabalhista, nos domínios do direito coletivo, persiste a distinção entre Homem e cidadão dos direitos humanos de primeira dimensão, que corresponde à cisão entre as esferas da economia e da política. Afinal, "la politique, pour le droit, c'est le fonctionnement des instituitions constitutionnelles, qui exclut la classe ouvrière en tant que classe, et la transforme en une somme de citoyens ${ }^{195, "}$. Paralelamente, aprisiona-se a classe operária no campo sindical, nas disputas por melhores condições de existência nos marcos do modo de produção existente.

A luta econômica, que poderíamos chamar também de sindical, sendo a única reconhecida como legítima pelo direito do trabalho, consiste no cotidiano da exploração capitalista, no fator ordinário de oscilação das taxas de mais-valia, e jamais conspira contra a exploração em si ${ }^{196}$. Ela faz parte do conjunto de instrumentos de reprodução social, razão pela qual se revela incapaz de ensejar uma transformação verdadeira ${ }^{197}$.

Homem (trabalhador) o econômico, ao cidadão a participação política. E a burguesia poderá então serenamente afirmar que a política para às portas da fábrica; ela poderá negar à classe operária a única prática de classe que lhe é própria - a greve - já que ela é a única prática em que a classe operária se organiza ela mesma, e por si mesma, sobre o local da produção.

Assim, por este simples qualificativo, os tribunais vão confinar as lutas operárias à legalidade, admitida como legalidade burguesa, é dizer, 'não-política'.

O que nos revela, então, a greve política? A luta de classe, sob a forma de uma luta irredutível entre duas organizações de poder: de um lado, a organização política burguesa, dominante, triunfante, com seus aparelhos constituídos (o aparelho de Estado); do outro lado, a organização política proletária, dominada, contaminada, reduzida sem cessar à luta 'econômica', à qual se nega todo caráter 'político'”.

${ }^{195}$ EDELMAN, Op. Cit., 1978, p. 68. Passando para o nosso idioma: "a política, para o direito, é o funcionamento das instituições constitucionais, que exclui a classe operária enquanto classe, e a transforma numa soma de cidadãos".

196 "A luta econômica é a luta coletiva dos operários contra os patrões, para conseguir condições vantajosas de venda da força de trabalho, melhorar as suas condições de trabalho e de vida. Essa luta é, necessariamente, uma luta profissional, porque as condições de trabalho são extremamente variadas nas diferentes profissões" (LENIN, Vladimir llitch. Que fazer? Problemas candentes de nosso movimento. Tradução de Marcelo Braz. São Paulo: Expressão Popular, 2010, p. 125).

197 O "economismo" combatido por Lênin já preocupava Marx: "Ao mesmo tempo, e completamente à parte da servidão geral envolvida no sistema de salários, a classe operária não deverá exagerar para si própria a eficácia última (the ultimate working) destas lutas de todos os dias. Não deverá esquecer que luta com efeitos, mas não com as causas desses efeitos; que retarda o movimento descendente, mas não muda a sua direção; que aplica paliativos, mas não cura a doença. Por conseguinte, não deverá estar exclusivamente absorvida nestas inevitáveis lutas de guerrilha que incessantemente derivam das investidas sem fim do capital ou das mudanças do mercado. Deverá compreender que, juntamente com todas as misérias que lhe impõe, o sistema presente produz simultaneamente as condições materiais e as formas sociais necessárias para uma reconstrução econômica da sociedade. Em vez do motto conservador, 'Um salário diário justo para um trabalho diário justo'! deverá inscrever na sua bandeira a palavra de ordem revolucionária: 'Abolição do sistema de salários'!" (MARX, Karl. Salário, preço e lucro, 5a ed.. Tradução de Silvio Donizete Chagas. São Paulo: Centauro, 2005, pp. 89-90). 
Congregando estas conjecturas, Edelman é extremamente perspicaz no seu diagnóstico e na sua síntese sobre o direito de greve:

Le droit de grève est un droit bourgeois. Entendons-nous: je ne dis pas la grève est bourgeoise, ce qui serait un non-sens, mais le droit de grève est un droit bourgeois. Ce qui veut dire très précisément que la grève n'accède à la légalité qu'à certaines conditions, et que ces conditions sont celles-là mêmes qui permettent la reproduction du Capital ${ }^{198}$.

Agora, voltemos nossas atenções ao conteúdo econômico das relações jurídicas trabalhistas. Notaremos novamente o favorecimento do modo capitalista de produção.

A primeira coisa a se notar é que o direito do trabalho incide sobre o comércio da força de trabalho, e não sobre a figura abatida do trabalhador. O objeto da relação jurídica trabalhista não é o trabalho, tampouco o trabalhador (que é um dos sujeitos), e sim a alienação da força de trabalho mediante pecúnia. É a perpetuação desta operação basilar que interessa ao Estado capitalista, e puramente por ser o eixo de sustentação de todo o sistema social, pressuposto primeiro do modo de produção capitalista.

Como qualquer mercadoria, a força de trabalho é formada por um valor-detroca e um valor-de-uso. Este último se confunde com sua utilidade imediata de ser fonte de valorização para o capital. Nesta perspectiva, importa a existência concreta e corporificada da mercadoria, e não o valor nela encerrado.

Marx conceituou esta mercadoria força de trabalho, em espírito de síntese, como o "conjunto das faculdades físicas e mentais existentes no corpo e na personalidade viva de um ser humano, as quais ele põe em ação toda vez que produz valores-de-uso de qualquer espécie ${ }^{199}$ ". Se não houver oferta suficiente deste conjunto de faculdades, comprometer-se-á o processo produtivo. No caso do capitalismo, a compra e venda da mercadoria em comento pressupõe a sua disponibilidade na praça econômica em condições aptas. Um mínimo de integridade é necessário para que seu valor-de-uso não se esvaia.

\footnotetext{
198 EDELMAN, Op. Cit., 1978, pp. 52-53. Traduzindo: "O direito de greve é um direito burguês. Escutemo-nos bem: não digo que a greve é burguesa, o que seria sem sentido, mas que o direito de greve é um direito burguês. Isto quer dizer muito precisamente que a greve não chega à legalidade a não ser sob certas condições, e que estas condições são aquelas mesmas que permitem a reprodução do capital".

${ }^{199}$ C., I, I, p. 197.
} 
Com efeito, os primeiros cuidados com a força de trabalho se apresentaram na legislação que estabelecia tetos para a jornada de trabalho. Serviremo-nos dos estudos de Marx sobre o assunto para elucidar o segredo do conteúdo das relações justrabalhistas e de sua "proteção".

Estamos cientes de que as legislações de controle da jornada de trabalho testemunhadas pelo autor teutônico integram o que seria mais adequado chamar de "pré-história do direito do trabalho", e não a forma mais acabada e moderna deste ramo do direito, que remete ao primeiro quadrante do século $X X$, ou quiçá ao segundo quadrante. No entanto, a racionalidade da reprodução econômica é a mesma no essencial, e Marx a descreve como ninguém.

Numa economia voltada para a valorização eterna do capital, e não para o fornecimento de utilidades tangíveis, a exploração ao longo do tempo da força de trabalho, fonte viva do valor, não conhece limites externos. Para o capital, o dia de trabalho "compreende todas as 24 horas, descontadas as poucas horas de pausa sem as quais a força de trabalho fica absolutamente impossibilitada de realizar sua tarefa ${ }^{200 "}$.

É evidente que, para recompor suas faculdades físicas e mentais após sua utilização na jornada de trabalho, o trabalhador necessita de repouso. Há outros fatores, como uma educação que lhe fomente desenvolvimento intelectual, condições de higiene e saúde decentes, alimentação razoável etc. Porém, é no descanso que se encontra um mínimo de controle para o dispêndio de cérebro, músculos e nervos e um meio de se afiançar a reposição destes itens.

Acaso o capitalismo se ocupa deste dado objetivo? Coloquemos assim: o sistema, sim; o capitalista individual, não. Marx afirma:

\footnotetext{
Mas, em seu impulso cego, desmedido, em sua voracidade por trabalho excedente, viola o capital os limites extremos, físicos e morais, da jornada de trabalho. Usurpa o tempo que deve pertencer ao crescimento, ao desenvolvimento e à saúde do corpo. Rouba o tempo necessário para se respirar ar puro e absorver a luz do sol. Comprime o tempo destinado às refeições para incorporá-lo, sempre que possível, ao próprio processo de produção, fazendo o trabalhador ingerir os alimentos como a caldeira consome carvão, e a maquinaria, graxa e óleo, enfim, como se fosse mero meio de produção. O sono normal necessário para restaurar, renovar e refazer as forças físicas reduz o capitalista a tantas horas de torpor estritamente necessárias para reanimar um organismo absolutamente esgotado ${ }^{201}$.
}

\footnotetext{
${ }^{200}$ C., I, I, p. 306.

${ }^{201}$ C., I, I, pp. 306-307.
} 
O capitalista impõe este tipo de regime em suas fábricas não por sadismo ou por obtusidade inerente. Só o que faz é dar vazão à lógica ${ }^{202}$ que comanda seus movimentos:

\begin{abstract}
A produção capitalista, que essencialmente é produção de mais-valia, absorção de trabalho excedente, ao prolongar o dia de trabalho, não causa apenas a atrofia da força humana de trabalho, à qual rouba suas condições normais, morais e físicas de atividade e de desenvolvimento. Ela ocasiona o esgotamento prematuro e a morta da própria força de trabalho. Aumenta o tempo de produção do trabalhador num período determinado, encurtando a duração da sua vida.

O valor da força de trabalho compreende o valor das mercadorias necessárias para reproduzir o trabalhador, ou seja, para perpetuar a classe trabalhadora. Se o prolongamento da jornada contra as leis naturais (o qual - capital, necessariamente, quer conseguir, em seu impulso desmedido para expandir seu valor) encurta a vida do trabalhador e, com isso, a duração da força de trabalho, torna-se então necessária a mais rápida substituição dos elementos desgastados. Aumentam os custos de desgaste na reprodução da força de trabalho. O mesmo ocorre com uma máquina: quanto mais rápido ela se desgasta, tanto maior a proporção do valor a ser reproduzida diariamente. $O$ interesse do próprio capital parece indicar a conveniência da jornada normal de trabalho ${ }^{203}$.
\end{abstract}

Está posta a contradição: de um lado, o capitalista quer consumir a força de trabalho que adquiriu da maneira mais lucrativa para ele, ou seja, exaurindo-a. De outro, esta exaustão conspira contra a reprodução social do sistema, que demanda disponibilidade de um exército industrial de reserva. A racionalidade individual do empregador esbarra nos interesses totalizantes do sistema.

Como se resolve a contradição? Na totalidade histórica. Em longo prazo, interessa ao capitalista individual que exista uma razão de Estado capaz de compelilo a promover um consumo sustentável da força de trabalho. Afinal de contas, não seria imaginável numa sociedade de mercado, de livre iniciativa, que os empresários se preocupassem individualmente com a preservação da engrenagem social. Só se espera deles que cuidem de seus interesses particulares, e nada mais. E tudo num horizonte imediatista:

O capital, que tem tão 'boas razões' para negar os sofrimentos da geração de trabalhadores que o circundam, não se deixa influenciar, em sua ação prática, pela perspectiva de degenerescência futura da humanidade e do

\footnotetext{
202 "Longe de ser um sistema 'natural', como alguns apologistas tentam argumentar, o capitalismo histórico é um sistema patentemente absurdo. Acumula-se capital para que se possa acumular mais capital. Os capitalistas são como ratos brancos em uma roda de gaiola, correndo cada vez mais rápido para poder correr cada vez mais rápido" (WALLERSTEIN, Immanuel. Capitalismo histórico e civilização capitalista. Tradução de Renato Aguiar. Rio de Janeiro: Contraponto, 2007, p. 37).

${ }^{203}$ C., I, I, p. 307.
} 
irresistível despovoamento final. Tudo isso não o impressiona mais do que a possibilidade de a Terra chocar-se com o Sol. Todo mundo que especula em bolsa sabe que haverá um dia de desastre, mas todo mundo espera que a tempestade recaia sobre a cabeça do próximo, depois de ter colhido sua chuva de ouro e de ter colocado seu patrimônio em segurança. Après moi le déluge! é a divisa de todo o capitalista e de toda nação capitalista. O capital não tem, por isso, a menor consideração com a saúde e com a vida do trabalhador, a não ser quando a sociedade o compele a respeitá-las. (...) De modo geral, isto não depende, entretanto, da boa ou da má vontade de cada capitalista. A livre competição torna as leis imanentes da produção capitalista leis externas, compulsórias para cada capitalista individualmente considerado ${ }^{204}$.

Foi o movimento do capital em sua fase industrial, sob constante pressão da concorrência, que ensejou o advento do controle do consumo da força de trabalho, o qual, em seu estágio mais avançado, desembocou nas garantias justrabalhistas. Foi apenas neste cenário em que a indústria forjava massas de excedente populacional que o movimento operário pôde se organizar para obter conquistas/concessões trabalhistas. A concentração fabril foi decisiva para as necessidades da indústria e para as forças de organização dos operários. Não há espaço aqui, como se vê, para a marcha incessante do espectro fantástico da dignidade humana. A dinâmica do capital, na sua reprodução e na sua luta de classes, pariu os direitos trabalhistas.

Com o direito do trabalho, a violência do capital contra a força de trabalho tornou-se, em certa medida, controlável e calculável. Isto interessa aos negócios, e não só pelo estoque de mão-de-obra no futuro. Torna-se viável contabilizar os custos com capital variável nos empreendimentos capitalistas. O clima é de mais segurança nos investimentos. A "anarquia" de um mercado de trabalho entregue integralmente à lei de oferta e procura é evitada.

Não obstante, nossos capitalistas queixam-se obstinadamente dos encargos trabalhistas (que envolvem o limite de jornada e outros direitos trabalhistas), destilando todo o seu azedume. Anunciam despesas exorbitantes e o desperdício de oportunidades. O "Custo País" é apresentado como uma cadeia odiosa amarrada aos pés da competitividade. Os riscos que nos descrevem são alardeados à maneira apocalíptica das maldições do Antigo Testamento. Pagar direitos é, para eles, como sorver um cálice de fel. Mas seria leviano inferir algum traço de "anticapitalismo" no rol de direitos trabalhistas por conta desta circunstância. Os queixumes esperneantes do capitalista individual revelam apenas a parcialidade de sua perspectiva e o egoísmo embutido em seu interesse objetivo na estrutura produtiva.

${ }^{204}$ C., I, I, pp. 311-312. 
A ofensiva neoliberal nos domínios do direito do trabalho, diga-se logo, é apenas um ajuste da intervenção estatal à acumulação flexível, e não um atentado contra o direito do trabalho em si. Não traduz nenhuma incompatibilidade ou hostilidade. O capital pretende apenas, nos dias de hoje, lograr contratos e direitos flexíveis $^{205}$, e não aniquilar uma forma social sem a qual não conseguiria embolsar o produto excedente.

O direito do trabalho - e isto vale para todo o rol dos direitos sociais - não é o "braço esquerdo" do Estado capitalista, como querem alguns, tampouco um abrigo aconchegante situado à margem da sociedade do capital. Não há nada mais prosaico do que se esquecer que o direito revela "a parcialidade de sua própria dominação como 'direito do trabalho' ou dos trabalhadores ao salário", mas "não revela sua antítese como direito do capital à mais-valia ${ }^{206 " . ~}$

Que não haja enganos: o direito do trabalho, como o direito em geral, é o terreno da burguesia. Ou ainda: "O direito do trabalho é o direito do capital sobre o trabalho, a forma com que o capital estrutura as relações de trabalho ${ }^{207 "}$.

\footnotetext{
${ }^{205}$ A acumulação flexível, de inspiração toyotista, demonstra uma nova filosofia de gestão da força de trabalho, buscando-se otimizar o desempenho empresarial (bem como o açambarcamento da maisvalia): "Outro ponto essencial do toyotismo é que, para a efetiva flexibilização do aparato produtivo, é também imprescindível a flexibilização dos trabalhadores. Direitos flexíveis, de modo a dispor desta força de trabalho em função direta das necessidades do mercado consumidor. O toyotismo estruturase a partir de um número mínimo de trabalhadores, ampliando-os, através de horas extras, trabalhadores temporários ou subcontratação, dependendo das condições do mercado. O ponto de partida básico é um número reduzido de trabalhadores e a realização de horas extras" (ANTUNES, Ricardo. Adeus ao trabalho: ensaio sobre as metamorfoses e a centralidade do mundo do trabalho, $12^{\mathrm{a}}$ ed.. São Paulo: Cortez; Campinas, SP: Editora da Universidade Estadual de Campinas, 2007, p. 36).

${ }^{206}$ SIMÕES, Op. Cit., 1979, p. 249.

${ }^{207}$ SIMÕES, Op. Cit., 1979, p. 52.
} 


\title{
5. O SOCIALISMO COMO ALTERNATIVA SUPERIOR AOS DIREITOS HUMANOS
}

\begin{abstract}
Em uma fase superior da sociedade comunista, quando tiver desaparecido a subordinação escravizadora dos indivíduos à divisão do trabalho e, assim, a oposição entre trabalho intelectual e trabalho manual; quando o trabalho tiver se tornado, não apenas um meio de vida, mas o requisito precípuo da vida; quando, com o desenvolvimento diversificado dos indivíduos, suas forças produtivas tiverem se incrementado também, e todas as fontes da riqueza coletiva jorrarem com abundância - só então o horizonte estreito do direito burguês poderá ser totalmente suplantado, e a sociedade poderá inscrever em sua bandeira: 'De cada um, segundo suas habilidades; a cada um, de acordo com suas necessidades ${ }^{208}$ !'
\end{abstract}

Nossa caminhada até aqui, em apertado resumo, revelou que os direitos humanos, celebrados como a menina dos olhos da jubilosa civilização burguesa e da época moderna, não oferecem a esperada emancipação da humanidade. Nem mesmo a segunda geração destes direitos rompeu com a lógica de exploração que anima o modo de produção capitalista e que engendra a forma jurídica.

A reação imediata do jurista frente a tal quadro é a desesperança. Se nem os direitos humanos são capazes de se contrapor às misérias propiciadas pelo capitalismo, o que resta? E se esses direitos são burgueses por definição, o que fazer com eles?

Jamais ocorreu ao jurista bem intencionado que as mudanças necessárias para a construção de um novo mundo não necessariamente passam pelo direito, e que o direito, ao contrário, consubstancia-se num obstáculo a ser derrubado.

"A história de toda sociedade até nossos dias é a história da luta de classes $^{209}$ ”, ensinaram Marx e Engels. É nesta luta que aparecem as respostas para as indagações que os homens se fazem acerca de seus desafios. A resposta que a classe proletária encontrou para seus problemas, em seu devir histórico, é o socialismo. Não que esta palavra esteja na ordem do dia, longe disso. Se afirmamos que o socialismo é a saída encontrada pela classe dos trabalhadores, é por se tratar do único modelo que enfrenta as causas da barbárie, apresentando uma alternativa radical, uma nova forma de sociabilidade. É o único projeto que efetiva e objetivamente corresponde aos interesses de classe dos trabalhadores.

\footnotetext{
${ }^{208}$ MARX; ENGELS, Manifesto do Partido Comunista, Op. Cit., 2006, pp. 107-108. A citação vem do texto "Gotha: Comentários à margem do Programa do Partido Operário Alemão", de Karl Marx, que está contido no livro indicado como referência bibliográfica.

${ }^{209}$ MARX; ENGELS, Manifesto do Partido Comunista, Op. Cit., 2006, p. 23.
} 


\subsection{O socialismo científico}

É preciso deixar muito claro o que entendemos pela palavra "socialismo". Cabe atribuir-lhe o significado exato construído pelo marxismo clássico. As experiências do chamado "socialismo real" (quanta malícia ideológica nesta infeliz expressão!) não falam em nome do conceito que ora invocamos, tampouco aquilo que se convencionou chamar de "socialismo de mercado" (o excruciante capitalismo chinês) e de "socialismo do século XXI" (o capitalismo desenvolvimentista "bolivariano", já em acentuado declínio).

O socialismo de Marx, merecidamente concebido como científico, insere-se num universo maior de "igualitarismo". É justo que lembrar que, se por um lado, a revolucionarização das relações de produção não está na agenda das principais organizações políticas, por outro, assiste-se hoje a um clamor de igualitarismo bastante acentuado. Amorfo, limitado, até despolitizado, em alguma medida; mas é uma chama que arde sem cessar.

Movimentos como o "Occupy Wall Street" e o "Anonymous" iniciaram-se na maior fortaleza do capital, e se espalharam por diferentes países. Nas palavras dos organizadores, está colocada a luta dos $99 \%$ da população contra $0 \quad 1 \%$ endinheirado. Um combate ainda pouco intenso, apesar do barulho causado. $\mathrm{Na}$ Europa, sobretudo na Espanha e na Grécia, as massas fazem sentir sua força. Sua palavra de ordem: "democracia". Espera-se que o povo participe das decisões sobre os orçamentos públicos. No Oriente Médio e no norte da África, assistiu-se a uma onda revolucionária que, impulsionada por trabalhadores levados ao desespero, redefiniu a geopolítica da região, e ainda agora produz efeitos.

Foram muitos os movimentos igualitaristas ao longo da história. A rebelião de Espártaco, o cristianismo primitivo, o Quilombo de Palmares etc. Na era capitalista, o igualitarismo passa a ser chamado de socialismo. Encontramos ideais de uma sociedade alternativa, mais equânime nos seus fundamentos econômicos, no socialismo utópico do século XIX (os Falanstérios de Fourier, as cooperativas de Proudhon, a inédita gestão fabril de Robert Owen) e mesmo no início do século XXI, com o "altermundismo" das correntes majoritárias do Fórum Social Mundial.

A busca por igualdade e justiça (admitindo-se logo a polissemia e a contingência histórica destes termos) inspirou e ainda inspira inúmeros movimentos. 
Sua insuficiência foi ilustrada por Rosa Luxemburgo em sua crítica ferrenha às ilusões do reformismo na ideia vaga de justiça:

\begin{abstract}
Chegamos assim com muita felicidade ao princípio da justiça, esse velho cavalo de batalha há milênios montado, por todos os reformadores de todo o mundo, à falta de meios históricos de transporte mais seguros, àquele lamentável Rossinante que, levando às costas todos os Don Quixotes da história, galopou para a grande reforma do mundo, para afinal trazer de volta para casa tristemente os seus cavaleiros amarrotados ${ }^{210}$.
\end{abstract}

O socialismo científico é parte desta aspiração por igualdade. No entanto, na medida em que consiste num projeto para além de anseios individuais, é dizer, na medida em que repousa, dialeticamente, nas bases do mundo que se quer transformar, ele se destaca do seu gênero. Aposenta-se o Rossinante, substituindoIhe por um corcel exuberante e vigoroso, que se afigura como um "meio histórico de transporte mais seguro" nas batalhas pela transformação. Nada a ver com qualquer concepção linear de um avanço da dignidade humana por seus próprios pés.

Dizendo de outro modo, o socialismo científico está baseado na compreensão de que o modo de produção capitalista, por suas próprias contradições internas, criou a possibilidade de sua superação, mas de uma superação que conduza ao fim de todas as classes, ao fim da exploração do homem pelo homem.

Cumpre recorrer à dialética de Marx para que melhor se compreenda o assunto:

Desintegrada a velha sociedade, de alta a baixo, por esse processo de transformação, convertidos os trabalhadores em proletários e suas condições de trabalho em capital, posto o modo de produção capitalista de produção a andar com seus próprios pés, passa a desdobrar-se outra etapa em que prosseguem, sob nova forma, a socialização do trabalho, a conversão do solo e de outros meios de produção em meios de produção coletivamente empregados, em comum, e, consequentemente, a expropriação dos proprietários particulares. $\mathrm{O}$ que tem de ser expropriado agora não é mais aquele trabalhador independente, e sim o capitalista que explora muitos trabalhadores.

Essa expropriação se opera pela ação das leis imanentes à própria produção capitalista, pela centralização dos capitais. Cada capitalista elimina muitos outros capitalistas. Ao lado dessa centralização ou da expropriação de muitos capitalistas por poucos, desenvolve-se, cada vez mais, a forma cooperativa do processo de trabalho, a aplicação consciente da ciência ao progresso tecnológico, a exploração planejada do solo, a transformação dos meios de trabalho em meios que só podem ser utilizados em comum, o emprego econômico de todos os meios de produção manejados pelo trabalho combinado, social, o envolvimento de todos os

${ }^{210}$ LUXEMBURGO, Rosa. Reforma ou revolução?. Tradução de Lívio Xavier. São Paulo: Expressão Popular, 2007, p. 87. 
povos na rede do mercado mundial e, com isso, o caráter internacional do regime capitalista. À medida que diminui o número dos magnatas capitalistas que usurpam e monopolizam todas as vantagens desse processo de transformação, aumentam a miséria, a opressão, a escravização, a degradação, a exploração; mas cresce também a revolta da classe trabalhadora, cada vez mais numerosa, disciplinada, unida e organizada pelo mecanismo do próprio processo capitalista de produção. $O$ monopólio do capital passa a entravar o modo de produção que floresceu com ele e sob ele. A centralização dos meios de produção e a socialização do trabalho alcançam um ponto em que se tornam incompatíveis com o envoltório capitalista. O invólucro rompe-se. Soa a hora final da propriedade particular capitalista. Os expropriadores são expropriados ${ }^{211}$.

Como se observa, a proposta está calcada em dois elementos dados pela realidade: a coletivização da atividade produtiva (o processo de produção), que contrasta com a individualização da apropriação, própria do capitalismo, e a formação de uma classe explorada numerosa, desprovida de tudo, e que só pode se emancipar sob a condição de assumir o controle dos meios de produção. Ao fazê-lo, inicia uma jornada de abolição das classes, inclusive da sua própria. Numa sociedade em que todos são trabalhadores, em que ninguém vive do trabalho alheio (a não ser as crianças, os idosos e os incapacitados para o labor), não há extração de produto excedente, assim como não há uma classe social que dele se aproprie para seu sustento. É a este desfecho comunista que a revolução socialista tem por objetivo último, e é por isso que somente a camada proletária da população é portadora de um interesse que pode ser universalizado. Nenhuma outra pode oferecer um modelo em que não haja subjugação.

E é por partir de uma contradição real e concreta, por existir em potência no interior do capitalismo e, principalmente, no âmago da classe proletária, que o socialismo de Marx é científico, diferenciando-se de iniciativas que não ultrapassam o marco das boas intenções de algumas lideranças. A história é uma âncora mais firme do que a mera aversão moral à tirania e à iniquidade, a base dos demais igualitarismos:

O projeto socialista do marxismo não propõe somente um plano bemintencionado, embora seja impossível derrotar o capital sem uma repulsa moral contra a injustiça. O socialismo não nasce somente da imaginação humana, mas de uma experiência histórica. A defesa do igualitarismo repousa em uma análise das condições objetivas e subjetivas que a própria experiência do capitalismo amadureceu ao longo dos últimos dois séculos $^{212}$.

${ }^{211}$ C., I, II, p. 876.

212 ARCARY, Op. Cit., 2006, p. 292. 
Esperamos, com isso, ter esclarecido que o socialismo de Marx é científico por suas raízes históricas e suas bases materiais, em oposição aos projetos que são extraídos do "bom coração" ou do audacioso horizonte visionário de seus elaboradores. É um socialismo que não está à frente de seu tempo, mas que, ao contrário, surge como uma alternativa a ser cultivada somente quando se reuniram os requisitos sociais para tanto. Seu objetivo é promover a posse coletiva dos meios de produção, iniciando-se, com isso, uma revolucionarização das relações de produção que avance para o âmago da divisão do trabalho:

\footnotetext{
Todas as riquezas sociais, o solo com todos os tesouros que abriga no interior e na superfície, todas as fábricas e empresas, enquanto propriedades comuns do povo, precisam ser tiradas das mãos dos exploradores. O primeiro dever de um verdadeiro governo operário consiste em proclamar, através de uma série de decisões soberanas, os meios de produção mais importantes como propriedade nacional e em pô-los sob o controle da sociedade.

Só então começa propriamente a mais difícil tarefa: a construção da economia em bases totalmente novas ${ }^{213}$.
}

Contra o socialismo, exsurgem infindáveis objeções. Algumas enaltecem o que entendem por méritos da sociedade capitalista. Outras contemporizam, afirmando que a intenção é boa, mas que a ideia é impraticável. E há outras, ainda, que já não se dão ao trabalho de discutir o assunto, refutando-o sumariamente sob o argumento de que o socialismo falhou no teste da história, sendo, por isso, nada mais do que um artefato de museu.

Nosso foco será encarar esta última objeção. Não porque ela seja mais respeitável do que as demais, e sim porque ela é a mais convincente. O impacto do fim da URSS levou um sem número de ativistas e organizações a rever suas estratégias e suas referências teóricas. Aí está o ponto central da questão: o que ruiu em 1991 foi mesmo um regime socialista?

A polêmica sobre o regime soviético é decisiva. Não foram somente os arautos das classes dominantes que se referiram a ele como sendo socialista de fato. A grande maioria dos trabalhadores do mundo pensava assim, e isto por conta das lideranças stalinistas no movimento operário e da máquina de propaganda

213 LUXEMBURGO, Rosa. A socialização da sociedade. In: LOUREIRO, Isabel M.. Rosa Luxemburgo - Vida e obra, 3aㅡ Ed. Tradução de Isabel Maria Loureiro. São Paulo: Expressão Popular, 2003, p. 58. 
burguesa. Neste processo, o próprio marxismo foi incriminado como uma apologia às perseguições políticas e aos assassinatos promovidos pelas burocracias. A falsidade desta acusação foi explicada por Valério Arcary:

\begin{abstract}
Os liberais invocaram a história identificando bolchevismo com stalinismo e denunciando as ditaduras burocráticas na União Soviética e na China como totalitarismo. Acusaram o marxismo de ser uma ideologia autoritária responsável por aberrações como os Processos de Moscou nos anos 1930 e pelo massacre em Pequim em 1989. Esquecem de mencionar, com freqüência, que as vítimas de Vichinski - o promotor encarregado de inventar as acusações ao serviço de Stalin - também eram marxistas: a maioria da velha guarda bolchevique foi condenada à morte a partir de 1936. Esquecem que os estudantes da Praça Tian An Men caíram cantando a Internacional.

Imputar ao marxismo - uma teoria e um programa - as misérias econômicosociais que foram camufladas pela burocracia em seu nome, como na exUnião Soviética, seria o mesmo que culpar o cristianismo - uma doutrina religiosa e moral - pelos crimes da Inquisição do Vaticano; seria o mesmo que atribuir à biologia evolucionista darwinista a responsabilidade pelos crimes de eugenia do nazismo, ou incriminar a física einsteiniana pelo dolo das armas nucleares. Esse recurso polêmico é obtuso e anacrônico.

Os ensinamentos religiosos, as ideologias políticas, assim como as hipóteses científicas certamente exerceram influência no processo histórico, mas não é sequer razoável conferir-lhes um peso tão grande. As idéias são apropriadas pelos sujeitos políticos arbitrariamente, como as palavras, expressando os conflitos e lutas entre as classes. Assim como não se pode julgar uma época por aquilo que ela pensou sobre si mesma, não se devem julgar as idéias pelos atos dos homens que as reivindicaram ${ }^{214}$.
\end{abstract}

Para se apreender a real natureza do regime soviético, não se pode dar ouvidos ao discurso liberal, tampouco ao discurso stalinista, que em nada se coaduna com a dialética marxista. É necessário agarrar pela raiz o método de Marx, limpando-o de toda a imundície com que a religião oficial do Estado soviético o conspurcou. O que esperar de uma crença fundamentalista que lança a figura obscura de Stálin como seu sumo pontífice?

Ao dialogar-se com marxistas dignos desta alcunha, mesmo que dentro de um espectro considerável de divergências, nitidamente se enxerga que os descaminhos da URSS não se reportam ao modelo do socialismo científico. Conheceremos agora a crítica marxista à União Soviética.

Leon Trotsky, fundador da Quarta Internacional, engajou-se na crítica do regime soviético, contribuindo em muito para a discussão. Em 1936, ele lançou o seu diagnóstico:

${ }^{214}$ ARCARY, Op. Cit., 2006, pp. 297-298. 


\begin{abstract}
A União Soviética é uma sociedade contraditória no meio do caminho entre o capitalismo e o socialismo, na qual: a) as forças produtivas são ainda insuficientes para dar à propriedade de Estado um caráter socialista; b) a propensão para a acumulação primitiva, nascida da necessidade, manifesta-se por todos os poros da economia planificada; c) as normas de distribuição que preservam a natureza burguesa são a base da nova diferenciação social; d) o desenvolvimento econômico, melhorando lentamente a condição dos trabalhadores, contribui para a rápida formação de uma camada de privilegiados; e) a burocracia, explorando os antagonismos sociais, tornou-se uma casta incontrolável, estranha ao socialismo; f) a revolução social, traída pelo partido governante, ainda existe nas relações de propriedade e na consciência dos trabalhadores; g) a evolução das contradições acumuladas pode tanto levar ao socialismo como de volta para o capitalismo; h) no rumo do capitalismo, a contrarevolução deverá quebrar a resistência dos operários; i) no caminho para o socialismo, os trabalhadores terão que derrubar a burocracia. Em última instância, a questão será resolvida pela luta das duas forças sociais, tanto na arena nacional como na internacional ${ }^{215}$.
\end{abstract}

A caracterização de Trotsky é bastante acertada no geral, mas merece algumas ressalvas. Destarte, cabe alertar que o desenvolvimento da riqueza e das forças produtivas, embora seja condição para o socialismo, não é requisito exclusivo e suficiente, como parece indicar a passagem isolada. Somente com a assunção do controle do processo produtivo é que classe trabalhadora pode efetivamente afrontar o capital enquanto mecanismo de metabolismo social. Por esse mesmo motivo, a propriedade estatal dos bens de produção, ainda que necessária em um primeiro instante, em nada assegura o fim do capitalismo e a edificação do socialismo. Trotsky tinha isso em mente:

\begin{abstract}
A propriedade privada, para se tornar social, tem que passar inevitavelmente pela estatização, tal como a larva, para se tornar borboleta, tem de passar por crisálida. Mas a crisálida não é uma borboleta. Milhares de crisálidas morrem sem chegarem a ser borboletas. A propriedade do Estado só se torna a de 'todo o povo' à medida que desapareçam os privilégios e as distinções sociais e, conseqüentemente, o Estado perca sua razão de ser. Em outras palavras: a propriedade do Estado torna-se propriedade socialista à medida que vai deixando de ser propriedade do Estado. E o contrário é verdade: quanto mais o Estado soviético se elevar acima do povo, quanto mais se opuser a ele, como guardião da propriedade do povo e dilapidador dessa propriedade, mais obviamente testemunha contra o caráter socialista da propriedade estatal ${ }^{216}$.
\end{abstract}

A URSS foi uma dessas crisálidas que jamais se promoveu a borboleta. $O$ Estado soviético, construído no calor da ascensão revolucionária do operariado russo e sob os escombros do antigo aparato czarista, passou por um processo de

215 TROTSKY, Leon. A revolução traída. Tradução de Henrique Canary, Paula Maffei e Rodrigo Ricupero. São Paulo: Instituto José Luís e Rosa Sundermann, 2011, p. 228.

${ }^{216}$ TROTSKY, Op. Cit., 2011, p. 215. 
involução. Ele degenerou de Estado operário para Estado burocrático ${ }^{217}$. A gestão operária das fábricas nos albores da revolução regrediu ao status quo ante, interrompendo a revolucionarização das relações de produção que estava em andamento ${ }^{218}$. A narrativa de Leon Trotsky atesta este fato:

\begin{abstract}
A passagem das fábricas para o Estado só mudou a situação jurídica do operário; de fato, ele vive na necessidade, trabalhando certo número de horas por um dado salário. As esperanças que o operário tinha, antes no partido e nos sindicatos, transferiram-se depois da Revolução para o Estado criado por ele. Mas o trabalho útil desse Estado foi limitado pela insuficiência da técnica e da cultura. Para melhorar uma e outra, o novo Estado recorreu aos velhos métodos: a pressão sobre os músculos e os nervos dos trabalhadores. Criou-se um corpo de condutores de escravos. $\mathrm{O}$ gerenciamento da indústria tornou-se extremamente burocrática. Os operários perderam toda a influência sobre a direção das fábricas. Trabalhando por produção, vivendo em difíceis condições materiais, sem liberdade de se deslocar, sofrendo na própria fábrica uma terrível repressão policial, o operário dificilmente poderá se sentir um 'trabalhador livre'. A burocracia é, para ele, um chefe, o Estado um patrão. O trabalho livre é incompatível com a existência do Estado burocrático ${ }^{219}$.
\end{abstract}

Aproveitamos a passagem para demonstrar como o direito é incapaz de ser revolucionário, já que a mudança da situação jurídica não significa uma mudança na situação material e concreta. A revolucionarização das relações de produção depende "inteiramente da luta de classe operária contra a dominação burguesa, ela se verifica fora do campo de intervenção do direito burguês, em um terreno que é, rigorosamente, não-jurídico ${ }^{220 \text { ", }}$.

O estudo de Trotsky é bastante frutífero, mas não é impecável. Seu grande defeito é não identificar que a burocracia alçou-se a classe dominante, é dizer, ao

\footnotetext{
${ }^{217}$ Trotsky utilizava a expressão "Estado operário degenerado", que é um tanto inadequada. O Estado ou é operário ou não o é. Se a classe operária não o dirige diretamente por seus organismos, então sua natureza de classe não pode ser operária, ainda que não seja o caso de se falar num Estado tipicamente burguês. Comentaremos isto em breve.

${ }^{218}$ Até o fim dos anos 1920, a revolução russa ainda não havia se exaurido, apesar dos seus reveses. Com a consolidação da burocracia, esse processo se encerrou: "O caráter provisório das medidas anti-proletárias e o reconhecimento de sua natureza burguesa por setores do partido; a existência de uma certa atividade livre das massas - cada vez mais restrita, no entanto - e a possibilidade de estas se organizarem na defesa de seus interesses imediatos; a existência de uma luta de tendências garantida por uma relativa liberdade de expressão dentro do partido bolchevique; a possibilidade de que viesse a constituir-se uma verdadeira aliança operário-camponesa, todos esses elementos, mesmo que se revelassem insuficientes para permitir à classe operária retomar a ofensiva contra a persistência de relações sociais capitalistas na sociedade soviética, revelavam que o processo revolucionário ainda estava em curso, que ele ainda não houvera se esgotado, e que a classe operária e o conjunto das massas ainda não havia sofrido uma derrota irreversível' (NAVES, Márcio Bilharinho. Stalinismo e capitalismo. In: NAVES, Márcio Bilharinho (org.). Análise marxista e sociedade de transição. Campinas: UNICAMP, Instituto de Filosofia e Ciências Humanas, 2005, p. $61)$.

${ }^{219}$ TROTSKY, Op. Cit., 2011, pp. 218-219.

${ }^{220}$ NAVES, Análise marxista e sociedade de transição. Op. Cit., 2005, p. 59.
} 
posto de classe exploradora, que vive do excedente de trabalho. Talvez isto não fosse claro em 1936. Não obstante, fato é que Trotsky considerava a camada burocrática como um parasita do Estado apenas, e não como uma autêntica classe social. Esta burocracia estaria "obrigada a defender a propriedade de Estado, fonte do seu poder e de sua renda", e o seu domínio sobre uma parte enorme do rendimento nacional seria "um caso de parasitismo social ${ }^{221 " .}$

Ora, ao se levar em conta que a burocracia dirigia o conjunto da produção sem a participação do proletariado, e agia contra ele, absorvendo para si o sobreproduto social, não há dúvidas de que este comportamento é o mesmo do capitalista em face do operário, do nobre feudal em face do servo, do senhor em face do escravo, e assim por diante. A sociedade soviética, indubitavelmente, foi castigada pelo flagelo da exploração do homem pelo homem.

Não está claro, contudo, se esta exploração se realizou propriamente à maneira capitalista. Charles Bettelheim desenvolveu estudos econômicos muito avançados e concluiu afirmativamente. Afirma o teórico, a respeito da União Soviética:

\begin{abstract}
As normas de gestão das empresas soviéticas baseiam-se, de forma crescente, nas dos países capitalistas 'avançados', e numerosos managers soviéticos vão se graduar em escolas de administração de empresa (as business schools) dos Estados Unidos e do Japão. O que deveria dar origem a relações sociais cada vez mais socialistas determinou 0 surgimento de relações essencialmente capitalistas, embora sob o disfarce dos 'planos econômicos'. Isto acontece porque são as leis de acumulação capitalista, e portanto o lucro, que determinam o emprego dos meios de produção.

Os produtores continuam sendo assalariados que se ocupam simplesmente em operar os meios de produção. Estes funcionam como um capital coletivo administrado por uma burguesia estatal, que constitui (como toda classe capitalista) o corpo dos 'funcionários do capital', expressão utilizada por Marx para caracterizar a classe capitalista. $O$ partido não propõe aos trabalhadores soviéticos senão a renovação indefinida dessas relações sociais. Trata-se, na prática, do partido dos 'funcionários do capital', e age como tal tanto no plano interno quanto no âmbito internacional ${ }^{222}$.
\end{abstract}

Apesar da solidez dos argumentos, falta uma conceituação mais exata do capital, o que faz toda a diferença. O problema é identificar a aludida acumulação capitalista na estrutura econômica da república soviética.

${ }^{221}$ TROTSKY, Op. Cit., 2011, p. 224. O autor russo só falava em exploração ao se referir à criadagem doméstica da camarilha burocrática.

${ }^{222}$ BETTELHEIM, Charles. A luta de classes na União Soviética: primeiro período (1917-1923),

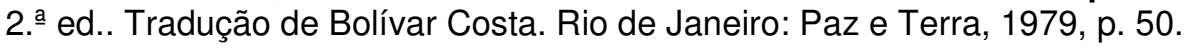


A sociedade soviética, como se sabe, era organizada, em suas bases, pelo assalariamento. O operário trabalhava para manter a si mesmo e para manter o Estado burocrático, que embolsava o trabalho excedente. Daí Bettelheim deduziu que se instalou "uma forma específica de capitalismo no qual a acumulação prossegue graças à centralização estatal da mais-valia e dos produtos do sobretrabalho", o que se daria por meio de aparelhos de Estado "constituídos principalmente pelo orçamento e pelo sistema bancário estatal ${ }^{223 " . ~}$

Com efeito, se quisermos identificar capitalismo com compra e venda de força de trabalho, não há como se negar a tese de Bettelheim. Mas esta operação mercantil está inserida num universo maior de fatores que não podem ser ignorados. Apresentaremos aqui algumas inquietações com a caracterização de capitalismo de Estado.

Verifica-se que, na URSS, a força de trabalho não circulava livremente pelo mercado, pois o único comprador era o Estado. O assalariado fabricava valor, é certo, mas e quanto ao preço dos produtos? Na ausência de uma rede mercantil interna, as leis da concorrência não operam, e com isso complica-se a noção exata de preço (que, por óbvio, transcende o valor, consistindo na oscilação em torno dele por força da autonomia relativa do dinheiro e das tendências de oferta e demanda). Estaríamos diante de um capitalismo desprovido de preços de produção?

No mesmo sentido, a ausência de circulação livre da força de trabalho conspira contra a ideia de um exército industrial de reserva, tão essencial ao modo de produção capitalista. A força de trabalho, mesmo sendo objeto de troca mercantil, era coagida por leis políticas, e não pelo mercado. Logo, diferentemente do que ocorre no modo de produção capitalista, a exploração ocorria fora do domínio exclusivamente econômico. Mais ainda: não se poderia amenizar este problema com a alusão à acumulação originária ou primitiva, e isto pela boa razão de que a continuidade de uma prática a descaracteriza como meramente "originária" ou "primitiva". Os operários soviéticos, no fim das contas, não estavam submetidos ao mesmo regime econômico que seus pares no ocidente capitalista, a despeito da paridade no processo de trabalho.

\footnotetext{
${ }^{223}$ BETTELHEIM, Charles; CHAVANCE, Bernard. O stalinismo como ideologia do capitalismo de Estado. In: NAVES, Márcio Bilharinho (org.). Análise marxista e sociedade de transição. Campinas: UNICAMP, Instituto de Filosofia e Ciências Humanas, 2005, p. 80.
} 
Outra dúvida que desponta é a questão das exportações de capitais. Uma economia gigantesca como a soviética, caso realmente fosse capitalista, não demandaria remeter massas de capitais para o exterior? Ao se contemplar o comércio internacional da União Soviética, nitidamente aparece a grande quantidade de mercadorias exportadas, mas a imagem de uma exportação de capitais não é muito convincente. Tanto é assim que o "imperialismo" da URSS sobre nações como o Afeganistão é de ordem muito diversa do imperialismo que, por exemplo, a França exerce sobre a Argélia. O segundo apresenta caráter tipicamente capitalista, sendo que o mesmo não vale para o primeiro.

Uma última inquietação: se a república soviética fosse capitalista, seria de se esperar que suas atividades estivessem orientadas pela lógica do valor, e não pela lógica do valor de uso. Colocando de outra forma, era de se esperar um movimento de acumulação infinita de capital. Ora, não nos parece comprovado que o regime da URSS tinha como objetivo valorizar o capital ao invés de abastecer a burocracia com valores de uso. Prova disto é a frágil atividade financeira soviética. Se o Estado soviético se comportasse autenticamente como agente capitalista, não deveria enveredar, ao menos em alguma medida, para o mercado financeiro?

Estas são apenas algumas dúvidas que nos impedem, no momento, de aderir ao modelo de Charles Bettelheim. Não nos é dado aqui, até pelo escopo desta obra (cujo cerne é a crítica dos direitos humanos e sociais, e não a crítica da URSS), realizar uma incursão mais aprofundada neste tema. Apenas para não ficarmos "em cima do muro", fazendo observações e questionamentos aqui e acolá, pairando confortavelmente sobre as polêmicas sem qualquer comprometimento (uma prática acadêmica comum e indesejável), propomo-nos a arriscar uma hipótese muito singela, algo absolutamente distante do que vem a ser uma tese científica.

Entendemos, ainda que com inúmeras limitações teóricas, que a União Soviética foi uma formação social em que o capitalismo conviveu lado a lado com um modo de produção que poderíamos chamar de "burocrático", oriundo da contrarrevolução burocrática que interrompeu a revolução socialista na Rússia. Um modo de produção em que a classe dominante se apossa diretamente do Estado, atrelando-se umbilicalmente a ele e, de certo modo, confundindo-se com ele.

O "modo de produção burocrático" foi uma excrescência histórica que nunca angariou existência autônoma. Ele surgiu e existiu por um curto período apenas por ter sido o resultado de uma revolução social interrompida, por ter sido o fruto amargo 
de um movimento que, ao não avançar, retrocedeu. Quando uma sociedade se encontra a "meio caminho entre o capitalismo e o socialismo", para se usar a expressão de Trotsky, e a classe trabalhadora não consegue intensificar a revolução que desencadeou, o retrocesso subsequente, que costuma se concretizar num afastamento drástico entre direção e base, enseja uma burocratização tal que acaba desfigurando o Estado que as massas ergueram para atender os seus interesses.

Coexistindo com o modo de produção capitalista, e dominando-o nos primórdios, o modo de produção burocrático experimenta um revés: ele perde a sua hegemonia no interior da formação social. Acaba dominado e, por fim, dissolvido, cedendo espaço para o expansionismo do capital, que pressiona por dentro e por fora, quer dizer, pelas contradições internas e pelo mercado mundial ${ }^{224}$. A burocracia converte-se definitivamente em burguesia, dando boas-vindas ao capital estrangeiro e incentivando os novos capitais nacionais. A restauração capitalista o demonstrou cabalmente na Rússia, na China e, mais recentemente, em Cuba.

O leitor há de ter notado que nossa hipótese é, em alguma medida, intermediária entre o modelo de Trotsky e o modelo de Bettelheim, pendendo para o primeiro.

Polêmicas à parte, resta incontestável que a União Soviética não foi uma real experiência socialista, e por isso seu exemplo não deveria ser usado nas objeções ao socialismo. É o que importa para nós neste capítulo.

\subsection{Socialismo e direitos humanos}

A trilha da revolução, com efeito, é perigosa, está carregada de incertezas. Fatores muito influentes incidiram sobre a jovem república soviética, que sucumbiu à contrarrevolução burocrática $^{225}$. O jurista, amedrontado, é o primeiro a desertar, esgueirando-se pelo primeiro atalho que encontra.

\footnotetext{
${ }^{224}$ Neste ponto em particular, a contribuição de Maria Turchetto está de acordo com o que expusemos: "O capital expande-se 'despedaçando' os modos de produção precedentes, quebrando os modos de produção precedentes, quebrando os nexos existentes dentro deles entre elementos objetivos e subjetivos do processo de trabalho, e subsumindo-os desse modo não tanto ao sistema das trocas, quanto à lei da valorização" (TURCHETTO, Maria. As características específicas da transição ao comunismo. In: NAVES, Márcio Bilharinho (org.). Análise marxista e sociedade de transição. Campinas: UNICAMP, Instituto de Filosofia e Ciências Humanas, 2005, p. 54).

${ }^{225}$ Convém evitar o longo debate e indicar as causas determinantes, sem examinar-lhes o peso específico no desfecho trágico. Além de alguns equívocos da direção bolchevique (o menor dos problemas), cumpre citar o frágil desenvolvimento econômico da Rússia czarista (agravado ainda pela guerra imperialista), a desmobilização do Exército Vermelho, as contingências extraordinárias da
} 
Não há nada mais atraente para o reformista que lida com o direito, e nele deposita sua fé, do que formular, em linguagem e conceituação jurídica, o ideal de uma nova sociedade. Mesmo nos juristas mais à esquerda, verifica-se uma insistente tentação de imaginar que a eficácia total dos belos enunciados das declarações de direitos humanos e das constituições redundaria no socialismo e na emancipação.

O jurista marxista é constantemente assediado por pensamentos como esses, até porque os sindicatos e os movimentos sociais esperam dele soluções jurídicas para os desafios que enfrentam. É como o "espinho na carne" de que Paulo se queixava, como a prova constante a que Satanás, segundo dizia, submetia a sua fé e a sua perseverança no apostolado. E quantos operadores do direito envolvidos em lutas, inclusive em revoluções, não fracassaram no seu "testemunho" em favor da radicalidade contida na estratégia socialista?

Recordemos apenas de José Joaquim Gomes Canotilho, que acreditou ser possível acomodar um programa socialista dentro da forma jurídica constitucional. Não causa espanto o malogro de uma pretensão como esta, inviável na perspectiva pasukaniana que abraçamos. Chegados os fatídicos anos 1990, o conteúdo da teoria do autor foi, enfim, oferecido em holocausto à forma burguesa, com o abandono da ousadia de outrora ${ }^{226}$. É o que acontece quando o jurista se aventura, sem qualquer ânimo crítico, a esperar alguma subversividade do direito: o fracasso, no instante imediato, e a capitulação, no instante posterior. Cedo ou tarde acaba acontecendo (com o jurista português, demorou décadas, mas aconteceu). Entre o caminho estreito e árduo da revolução e o aconchegante discurso jurídico, a maioria dos operadores do direito faz a escolha que lhes é óbvia enquanto operadores do direito. Não obstante o constitucionalismo progressista embutido na doutrina de

guerra civil e o isolamento oriundo da derrota da revolução mundial. O fracasso da revolução alemã foi o golpe mais duro - não se deve olvidar o internacionalismo como condição inerente e necessária ao socialismo científico.

226 A lastimável travessia do autor coincide com a lastimável travessia do seu conceito de "constituição dirigente", como se depreende da narrativa de Flávio Batista: "A expressão "constituição dirigente' foi cunhada pelo jurista português José Joaquim Gomes Canotilho, socialista e coautor do texto da Constituição portuguesa de 1975, para interpretar o significado de tal documento na história de seu país. A ideia foi expressa em sua tese de doutoramento, que acabou se tornando um livro clássico. Em sua adaptação ao estudo da Constituição brasileira, a ideia de direção jurídica para o socialismo implícita ao conceito de constituição dirigente transformou-se, de forma muito mais abstrata, em direção jurídica para objetivos de justiça social, com o que a constituição dirigente e suas normas programáticas passaram a significar a constituição de objetivos de Estado, e não mais a transição de modo de produção" (BATISTA, Op. Cit., 2012, p. 148). 
Canotilho, muito útil ao jurista de esquerda na sua atividade prática, o apego às categorias jurídicas revela-se incompatível com a práxis classista e socialista.

Ainda assim, convém reconhecer que se está diante de algo realmente tentador. Por que engajar-se numa causa tão radical, direcionada para um fim tão drástico, se já temos, aqui no Brasil, uma nobre constituição que, logo no seu preâmbulo, institui um Estado Democrático "destinado a assegurar o exercício dos direitos sociais e individuais, a liberdade, a segurança, o bem-estar, o desenvolvimento, a igualdade e a justiça como valores supremos de uma sociedade fraterna, pluralista e sem preconceitos, fundada na harmonia social e comprometida, na ordem interna e internacional, com a solução pacífica das controvérsias"? Por que combater as instituições de uma República que tem por objetivo fundamental "construir uma sociedade livre, justa e solidária" (art. 3.ำ I, CF/1988)? Não seria o caso de se envidar esforços para aplicar o que já está legalmente dado?

Numa formulação tipicamente altermundista, Fábio Comparato propõe que o conjunto dos direitos humanos como um sistema tem se contraposto ao capitalismo predatório:

\begin{abstract}
Felizmente, em contraste com o desnorteamento e o caráter mundialmente predatório do capitalismo, assistimos à progressiva formação do conjunto dos direitos humanos como um sistema, no sentido que este conceito assume hoje na biologia e nas ciências humanas. Nos mais diversos países, assim como no plano das relações internacionais, reforça-se continuamente a conexão entre direitos individuais e direitos sociais, entre direitos dos povos e direitos da humanidade. Nesse ambiente comunitário, tudo se submete ao princípio da igualdade fundamental dos seres humanos, com a preservação de suas legítimas diferenças biológicas e culturais ${ }^{227}$.
\end{abstract}

A primazia dos direitos humanos sobre os imperativos econômicos do capitalismo seria, afinal, um roteiro para a "humanização do mundo". Uma legítima reedição do socialismo jurídico, ou quiçá o "socialismo jurídico do século XXl”!

Acreditamos que os laços íntimos entre capitalismo e direitos humanos e sociais estejam devidamente explanados. Estamos em condições, então, de perceber que a oposição entre esses direitos e o capitalismo é inteiramente falsa, e que o incremento das relações jurídicas não pode conspirar contra o tipo de sociedade que as desenvolve.

${ }^{227}$ COMPARATO, Fábio Konder. Ética: direito, moral e religião no mundo moderno. São Paulo: Companhia das Letras, 2006, p. 699. A conexão entre os direitos humanos sugerida, é bom que se diga logo, jamais ultrapassou a esfera acadêmica. 
O renomado filósofo do direito deseja um mundo onde haja mais direitos civis e políticos. Sem o constatar, ele enaltece a democracia burguesa e o liberalismo, que jamais tutelarão os interesses de todos os homens. Outrossim, ele deseja um mundo onde haja mais direitos sociais. Sem o saber, ele almeja que o mercado capitalista seja continuamente suprido em sua demanda por força de trabalho.

Não ignoramos o clima de liberdade superior e o nível civilizatório material que os direitos humanos propiciam. Seria bastante insensato pretender que as belas páginas escritas por Comparato estejam desprovidas de qualquer fundamento real. O que não se pode ignorar, porém, é a constante conversão da liberdade burguesa em despotismo contra o trabalhador insatisfeito, bem como a oscilação do bem-estar do operário ao arbítrio dos padrões de acumulação. Está meridianamente claro, para quem quiser enxergar, que nem as mais sublimes categorias jurídicas estão aptas para enfrentar as raízes do problema. Pelo direito, o operador pode ser progressista, combativo, audacioso... só não consegue ser radical!

Ao jurista é dado fazer o que quiser e crer naquilo que melhor lhe aprouver, desde que aceite as consequências. Pode acreditar que o direito comporte instrumentos capazes de reverter os males do capitalismo, e que os direitos humanos conspirem contra este sistema. No entanto, o mais adequado é que, ao seguir esse caminho, reconheça a renúncia a uma leitura marxista. Não que Fábio Comparato a tenha reivindicado em algum instante, longe disto.

Mas mesmo entre os juristas marxistas, há de se notar, por vezes, algum encantamento pelo direito, e em particular pelos direitos humanos; enxerga-se neles algum papel de destaque nas lutas obreiras. É como se eles servissem como um "chamado" ou uma "ponte" para o socialismo, ou quiçá um atalho. Quando se vê, até um autor extremamente versado nas letras do marxismo, como Tarso de Melo, acaba cedendo em parte ao ardiloso "charme" do direito. Acompanhe-se uma proposição do autor:

A dinâmica entre conservação e transformação da sociedade, que caracteriza a ambiguidade do direito e, em especial, dos direitos sociais encontra na Constituição de 1988 um exemplo preciso. Mesmo numa observação rápida de seus artigos é possível concluir que se trata exatamente de uma Constituição que se propõe mais a transformar do que a conservar a sociedade: desde a forma como foram fixados os seus princípios fundamentais até a decisão sobre quais são os objetivos fundamentais da República, passando por artigos que detalham como devem ser respeitados aqueles princípios e alcançados estes objetivos, todo o texto constitucional pode ser lido como um projeto para transformar 
profundamente a sociedade brasileira. Um país que, após os anos de ditadura militar, pouco tinha a conservar, é normal que se apresente constitucionalmente por meio de um grande e quase revolucionário projeto de transformação ${ }^{228}$.

Importa apresentar, por justiça ao autor e por integridade intelectual, a sua preocupação quanto ao conteúdo semântico das categorias de "ambiguidade" e à "resistência" a que se reporta:

Optei pelos termos ambiguidade e resistência, em vez de algo como contradição e revolução, porque acredito que o nível dos conflitos ideológicos e políticos que se colocam no direito não atinge a profundidade de uma contradição concreta no sistema, tampouco permitem uma transformação completa das estruturas sociais. O que interessa, aqui, é perceber as possibilidades de elaboração de lutas que, mirando contra o direito, visam atingir, na verdade, alvos muito mais ambiciosos ${ }^{229}$.

A ressalva é oportuna, reconhecemos; ainda assim, não nos damos por satisfeitos. Não há como se admitir a hipótese de uma constituição vocacionada para a transformação. Uma constituição nada mais é do que o universo do jurídicopolítico por excelência, o ponto de intersecção entre o conservantismo do direito e o conservantismo do Estado; é o elo entre a forma que reveste as relações capitalistas e a violência de classe concentrada. É o direito burguês organizando as entranhas institucionais do Estado burguês. Como extrair deste arranjo algum élan transformador? É mais fácil identificar o oposto: a história do constitucionalismo é a história do Termidor e da contrarrevolução, é a torrente voltada para a contenção das forças desencadeadas pelo conflito de classe ${ }^{230}$.

O autor persegue na constituição, destarte, algum espaço capaz de prover à classe obreira um patamar básico de cidadania, sem o qual ela pereceria. Em seguida, foca-se nos seus "alvos muito mais ambiciosos". Da defesa de condições basilares, avança ao intuito declarado de desarranjo do mundo do capital, com a pretensão de exaurir suas possibilidades, distender seu discurso até o limite, forçar

\footnotetext{
${ }^{228}$ MELO, Tarso Menezes de. Ambiguidade e resistência: direito, política e ideologia na neoliberalização constitucional. Tese (doutorado). São Paulo: USP, 2011, p. 54.

${ }^{229}$ MELO, Op. Cit., 2011, p. 17.

230 "Em 1789, constituição e revolução coincidem. A concretização da revolução é a constituição. Com a perpetuação do estado revolucionário, tornam-se incompatíveis. A constituição passa a ser exigida por aqueles preocupados em terminar a revolução, vista agora como geradora de desordem, e não de ordem. (...) Na passagem do estado revolucionário para o estado ordinário, se faz necessária a função ordenadora e estabilizadora da constituição. O ato constitucional vai, assim, bloquear a revolução" (BERCOVICI, Op. Cit., 2008, p. 158).
} 
seus recursos. É cabível, em sua obra, uma distinção entre objetivos mais modestos e objetivos mais ousados.

Sabemos que Melo não sugeriu o viés transformador da Carta de 1988 por conta do discurso nela inserido. Nenhum marxista efetivamente julgaria um fenômeno apenas pela imagem que ele apresenta de si mesmo. É óbvio que o autor tem em mente a intensa mobilização operária e popular dos anos 1980. Esta percepção está corretíssima. O que lhe falta é entender a que veio a constituição. Não para impulsionar o processo que desembocou nela, e sim para the tolher, para Ihe traçar as fronteiras finais, agindo com toda a força do novo regime de democracia burguesa. Não à toa, o entulho corporativista da organização sindical foi recepcionado, apesar da hipócrita anunciação de liberdade sindical.

A linguagem "esquerdista" do texto constitucional, que de maneira alguma está isenta dos ornamentos ideológicos que rendem homenagem aos valores da burguesia, corresponde realmente ao ascenso das massas (um ascenso vitorioso, que derrotou uma ditadura); a reestruturação do regime burguês pela reorganização dos aparelhos de Estado, por outro lado, ditou o conteúdo da nova constituição, atrelando-Ihe às funções reprodutivas do direito e do Estado.

Essa linguagem do texto constitucional, e das declarações de direitos em geral, é bom que se diga, reforça o fetiche do fenômeno jurídico. O direito parece usurpar a autoria de conquistas que foram obra dos trabalhadores, e não da varinha de condão de entes fantasmagóricos como o "Constituinte" e o "Legislador". O pouco que o operariado obtém a duras penas acaba colocado na conta do direito, e não da classe em ação! Nem mesmo a consecução dos objetivos mais modestos é confiada aos obreiros. É bastante útil, no debate, a contraposição de Juary Chagas:

\footnotetext{
Portanto, não é o direito que garante avanços imediatos, econômicos ou parciais aos trabalhadores, mas, a própria organização e a luta da classe explorada que alteram a correlação de forças e conseguem fixar essas novas condições dentro do próprio capitalismo, impondo sua consagração legal pelo direito ${ }^{231}$.
}

Por esta citação, entende-se agora algo que os juristas dificilmente aceitam: o direito não evolui. O direito não é dialético. Ele não muda, não há nele nenhum motor interno. Ele é apenas tensionado, "de fora para dentro", pelo embate entre as

\footnotetext{
${ }^{231}$ CHAGAS, Juary. Sociedade de classe, direito de classe: uma perspectiva marxista e atual.
}

São Paulo: Instituto José Luís e Rosa Sundermann, 2011, p. 95. 
forças socialmente operantes. O confronto político é a substância, a forma jurídica é a carcaça que circunscreve aquilo que the foi politicamente imposto nos patamares da estrutura capitalista. Os "excessos" da luta política são extraídos do político e enquadrados no jurídico. Quando o sujeito-cidadão extrapola o campo do sufrágio e a zona de tolerância para ações diretas (protestos, passeatas etc.), o direito é chamado para cumprir seu papel.

Perceba-se, em adendo, que quando Chagas diz "consagração legal pelo direito", não restam dúvidas acerca da recepção de um conteúdo por uma forma. $\mathrm{E}$ diríamos mais: extrai-se daí um decisivo intervalo de tempo. A apreensão da resultante política pelos contornos jurídicos é invariavelmente a posteriori, configurando a consumação de um quadro já estabelecido.

Imaginar que o direito cria política é como imaginar que uma máquina produza valor. Ledo engano: assim como a máquina não passa de trabalho morto, objetivado, que não serve para nada sem o trabalho vivo do operário, os direitos humanos cristalizados nas constituições e declarações eventualmente forjadas no calor de um levante de massas são, de certo modo, "política morta, objetivada". Os avanços econômicos resultam da "política viva", do pulsar da ação coletiva. A política corporificada na ossatura jurídica é política pretérita, inapta para colocar em movimento o que está parado.

As garantias constitucionais, nesta ordem de considerações, são efeitos, e não causa, do embate político. As classes exploradas não se colocam em movimento porque existe um documento institucional que lhes reconhece um direito ao bem-estar material. Elas se colocam em movimento porque é objetivamente necessário, e a ordem jurídica jamais as estimula a isto. Só o que ela faz é envolver as classes laborais em rituais reformistas e institucionalizados.

Trabalhemos com o exemplo do MST, que tanto interessa a Tarso de Melo. As ocupações de terra não ocorrem porque a constituição prevê que a propriedade deve atender a uma função social. Elas ocorrem porque um considerável contingente de trabalhadores sem-terra está privado dos bens de produção e condenado à pobreza. A ordem jurídica, associando-se ao Estado, nunca os convidou a ocupar terreno algum. Ela os convida, isto sim, a aderir aos órgãos oficiais de colonização e reforma agrária (compute-se aí o peso decisivo da administração petista), cuja atuação não é capaz sequer de arranhar os interesses dos antigos latifundiários e do agronegócio. A constituição até "almeja" a reforma 
agrária, desde que em observância aos ritos legais e sob a direção dos órgãos oficiais. O intento é cristalino: retirar da luta de classes o debate em torno da estrutura fundiária e encerrá-lo na institucionalidade.

Se a reforma agrária e outros direitos figuram no âmbito constitucional, daí se tem nada mais do que um estorvo para as contrarreformas neoliberais. Um estorvo desejável, mas incapaz de assegurar indefinidamente as conquistas do passado. A exigência de um quorum parlamentar qualificado para emendar a constituição representa, aqui, uma relativa zona de conforto, e só. Esta posição hierárquica, por si, não desperta nas camadas exploradas nenhum ímpeto subversivo. Sua relevância será significativa nas querelas doutrinárias e, até certo ponto, na jurisprudência. A correlação de forças entre os sujeitos sociais não depende do direito, embora uma modificação nesta correlação de forças, não raro, se exprima pelo direito, ainda que momentaneamente.

O importante aqui é se notar que, sobretudo em constituições de caráter "dirigente", a política acaba capturada para dentro da institucionalidade. Os obreiros contemplam com perplexidade estes documentos pretensiosos, carregados de ecos do passado, quando deveriam estar olhando para o conflito concreto e real de um presente já assombrado pelo porvir. Esperam respostas de uma luta que já foi travada e se defendem com os reflexos dela. As muralhas jurídicas são feitas de manteiga. A legítima argamassa está fora do direito.

E se o direito se revela inadequado para fins defensivos, o que esperar de fins "ofensivos", como "elaborar lutas", ou então impulsioná-las?

Cabe levar em conta que, na sociedade burguesa, os programas políticos inevitavelmente assumem a clássica roupagem de reivindicações jurídicas ${ }^{232}$. A luta por educação, moradia e cultura aparece como a luta pelo direito à educação, à moradia e à cultura. A pauta, porém, é o conteúdo, e não a forma. O direito é a mediação formal que acomoda o combate político ao devir do capitalismo.

Com isso, tem-se que o direito não "elabora lutas". Pensar assim é atribuir ao direito um poder exagerado, quase sobrenatural. As lutas, ao contrário, encontram nele um obstáculo, ou ao menos um filtro. Aceitar que a luta de classes seja reduzida a uma luta por direitos é decretar a falência da estratégia revolucionária,

232 "As reivindicações resultantes dos interesses comuns de uma classe só podem ser realizadas quando esta classe conquiste o poder político e suas reivindicações alcancem validade universal sob a forma de leis. Toda classe em luta precisa, pois, formular suas reivindicações em um programa, sob a forma de reivindicações jurídicas" (ENGELS; KAUTSKY, Op. Cit., 1995). 
que encara a questão do direito como um assunto rigorosamente tático. Lidar com o direito, e com os direitos humanos não é diferente, deve ser um exercício de conveniência e oportunidade para a classe trabalhadora. Se a classe proletária santificar os direitos sociais, ou seja, enaltecê-los acriticamente, por exemplo, agarrando-se à forma jurídica, como poderá questionar a propriedade privada e o império dos contratos? Restar-lhe-ia apenas explorar a vagueza de termos como função social dos contratos e da propriedade, e depois orar para o Judiciário acolhesse suas teses.

O uso tático da legalidade, isto é, a sua utilização conforme o juízo de conveniência e oportunidade dos trabalhadores organizados, é a negação da ideia mesma de legalidade. Assumir que o apelo e a observância ao sistema jurídico estejam subordinados a um juízo político, quer dizer, ao talante de uma reflexão externa à racionalidade do direito, implica a falência da ideologia jurídica. O respeito totêmico pelo império da lei cai por terra, e com ele o fundamento ideológico da ordem burguesa liberal.

Com o repertório dos direitos humanos, não se consegue ir assim tão longe. É simplesmente incogitável, na seara jurídica, um discurso que caprichosamente escolhe os itens da constituição e das declarações de direitos que devem ser respeitados. Aquele que se situa no terreno jurídico, e que a ele se limita, não pode contestar o direito de propriedade e aprovar o direito à moradia ao mesmo tempo. Politicamente, a disjunção entre o desfrute da propriedade e o acesso à habitação é possível, na eventualidade de um conflito possessório. Juridicamente, "domínio" e "habitação" são bens que se equivalem hierarquicamente e que dependem um do outro. Um não pode negar o outro, pois uma carta constitucional não poderia consagrar, em seu interior, direitos fundamentais incompatíveis entre si. Lembremos que o raciocínio jurídico-dogmático é hostil à dialética e ao seu espírito contraditório. No máximo, admite alguma aporia kantiana!

É inútil que alguns juristas progressistas acreditem num Estado e num direito "divididos" e "em disputa", como se comportassem uma alma cindida em personalidades opostas, com duas naturezas distintas e em guerra. A constituição, espelhando esse fantasioso antagonismo, teria uma face esquerda (os direitos humanos e sociais) e uma face direita (os institutos do liberalismo clássico de mercado e da ossatura estatal). Ora, não é a propriedade privada um direito 
humano? O mesmo vale para a "livre iniciativa" contratual. Como apartar o lado esquerdo do lado direito?

A chamada "disputa" pelo direito não é nada mais e nada menos do que uma atenuação do liberalismo. Mas uma ordem "menos liberal" não deixa de ser liberal ainda em sua essência, do mesmo modo que a propriedade e o contrato com função social não deixam de ser propriedade e contrato.

Não caberia falar, então, em coisas como duas constituições num mesmo diploma, ou dois projetos coexistindo na mesma moldura. A constituição é uma só, e não é por acaso que, nela, os direitos do homem e as regras do mercado estão de mãos dadas. O confronto épico pela prevalência da "alma progressista" do direito, em detrimento de sua "alma conservadora", existe apenas na imaginação dos juristas dotados de boas (mas insuficientes) intenções ${ }^{233}$. É de se supor que também não tenham entendido "O Médico e o Monstro" antes que Robert Louis Stevenson escancarasse, no capítulo final, o que há muito figurava nas entrelinhas: Jekyll e Hyde eram um único e mesmo ente. "Jekkyl/Hyde” era "ambíguo", sabemos. Sua ambiguidade estava enraizada na indivisibilidade do seu ser aparentemente conflituoso. O cordato Dr. Jekyll era o perverso Sr. Hyde, e o perverso Sr. Hyde era o cordato Dr. Jekyll. Seria muito cômodo acolher um e afastar o outro ao mesmo tempo. Infelizmente, a realidade não nos oferece comodidades. Não é concebível apegar-se aos direitos humanos e deixar de lado sua condição burguesa, a não ser que eles sejam aproveitados de forma estritamente tática e residual. Aí, porém, o horizonte deixa de ser o da ideologia jurídica. A legalidade dos direitos humanos não pode ser "opcional". Ao se adotar a lei apenas quando for do interesse da classe, a legalidade não se impõe como dogma e como roteiro; e se ela não se impõe assim, as amarras do direito ficam mais frouxas. Nada ofende tanto o universalismo burguês como a atitude de desprezo pelo império da lei, isto é, o comportamento pelo qual a política de classe toma a liberdade de decidir se emprega ou se desdenha o direito ${ }^{234}$. Colocar a razão política e classista acima da razão jurídica

${ }^{233}$ Fica a indagação: não haveria aí algum "pluralismo jurídico" enrustido? Não se assume abertamente a hipótese de ordens jurídicas alternativas, mas se propõe uma alternativa internalizada na própria ordem oficial. Caberia ao jurista e aos trabalhadores, cada um no seu espaço, o papel de destrinchá-la, até que ela deixasse de ser alternativa e se tornasse "hegemônica". Pensar a constituição como "campo de luta social" fatalmente conduz a embaraços como este.

${ }^{234}$ A reflexão de Lukács sobre a questão da legalidade e da ilegalidade vai ao encontro do que propomos: "A questão da legalidade e da ilegalidade para o Partido Comunista se reduz à tática momentânea, sobre a qual dificilmente poderiam ser indicadas diretrizes gerais, uma vez que ela deve ser decidida inteiramente com base numa conveniência imediata. Nessa tomada de posição, 
universalista é um petulante desaforo que nega o discurso do capital e nega o direito como aposta estratégica. Melhor ainda: faz troça desta aposta.

Debalde se aguarda que o direito presenteie a humanidade com uma solução. O grito de guerra do socialismo científico contra o capital ainda não calou fundo nos corações da esquerda jurídica. Mas isto não importa. O materialismo históricodialético não se modula ou se ajusta de acordo com as cândidas intenções dos juristas progressistas. Os esforços cotidianos nos fóruns e os votos por um direito mais equânime não devem afastar o rigor da análise. Marx e Pasukanis iluminaram o caminho da investigação sobre o lugar da forma jurídica na revolução socialista, esta sim uma empreitada emancipatória. A construção do socialismo atua no sentido de aniquilar o direito, e não de afirmá-lo.

Considerando-se que o socialismo caracteriza-se pela contínua e progressiva superação da forma mercantil, ou seja, que numa sociedade como esta as relações de produção não convertem os produtos em mercadorias, deduz-se que o direito, enquanto forma de mediação originada pelo mercado capitalista, tende a ser igualmente superado. Se os homens deixam de trocar bens que fabricaram isoladamente (indivíduos com interesses isolados na comunidade) e começam a prover sua existência no plano coletivo, não será cabível dizer que continuam se comportando como sujeitos de direito, e não haverá nenhuma relação jurídica entre as pessoas. Quanto mais se avançar na edificação da sociedade socialista, tanto mais se aproximará o dobre de finados da forma jurídica, pois esta só encontra seu substrato econômico na permuta social de equivalentes.

Esta conclusão é óbvia e necessária quando se assume a concepção pasukaniana sobre o direito, que propõe um elo indissolúvel entre capitalismo e forma jurídica - elo este cuja identificação já estava em Marx ${ }^{235}$. A prova decisiva é a rejeição expressa da ideia de um "direito socialista":

que não se atém a nenhum princípio, encontra-se a única forma de rejeitar na prática e por princípio a validade da ordem jurídica burguesa. Semelhante tática é prescrita aos comunistas não somente por motivos de conveniência. Não apenas porque somente assim sua tática pode adquirir flexibilidade e capacidade de adaptação às exigências do momento dado, ou porque as armas legais e ilegais têm de ser sempre alternadas e muitas vezes até mesmo usadas simultaneamente nos mesmos casos, a fim de poder combater a burguesia de maneira realmente eficaz. Essa tática também é necessária para a formação revolucionária e autodidata do proletariado. Pois este só consegue se libertar de sua dependência ideológica relativa às formas de vida criadas pelo capitalismo quando aprende a impedir que elas influenciem internamente suas ações e quando consegue vê-las como motivos sem a menor importância" (LUKÁCS, Op. Cit., 2012, pp. 477-478).

${ }_{235}$ "Marx mostra ao mesmo tempo a condição fundamental, enraizada na estrutura econômica da própria sociedade, da existência da forma jurídica, isto é, da unificação dos diferentes rendimentos do 
"O desaparecimento de certas categorias (de certas categorias, precisamente, e não de tais ou quais prescrições) do direito burguês não significa em hipótese alguma a sua substituição por categorias do direito proletário. Igualmente o desaparecimento das categorias Valor, Capital, Lucro, etc., no período de transição para o socialismo evoluído, não significa o aparecimento de novas categorias proletárias de Valor, Capital, etc.

O desaparecimento das categorias do direito burguês significará nestas condições o desaparecimento do direito em geral, isto é, o desaparecimento do momento jurídico das relações humanas ${ }^{236 " . ~}$

\section{Oportuno se faz trazer o raciocínio de Márcio Bilharinho Naves:}

O problema da relação entre o direito e o socialismo é o 'centro nervoso' da teoria pachukaniana. Poderíamos mesmo dizer que é com base nela, isto é, no modo como Pasukanis apresenta esta questão e a resolve, que a sua análise da relação entre a forma jurídica e a forma mercantil se ilumina e ganha pleno significado - a um tempo teórico e político. De fato, se Pachukanis admitisse a possibilidade de um direito 'socialista', toda a sua construção teórica estaria comprometida. Se o socialismo implica a gradativa superação das formas mercantis, um direito que se qualificasse como 'socialista' seria tanto uma impossibilidade teórica como um objeto a ser combatido politicamente. Se o socialismo implica a gradativa reapropriação pelas massas das condições materiais da produção, com a superação da separação entre os meios de produção e a classe operária e a extinção das formas mercantis, isso significa que o fundamento último da existência do direito é negado na fase de transição, e a persistência do direito só pode aparecer como um obstáculo ao socialismo - mesmo que o direito possa, durante certo tempo, cumprir determinado papel 'revolucionário'237.

Esta é uma má notícia para o jurista. Note-se que a afirmação é categórica: desaparece o "direito em geral", ou seja, encerra-se o "momento jurídico das relações humanas". Nem os direitos humanos são poupados! A menos, claro, se os concebêssemos como "não jurídicos", isto é, como meras aspirações e expressões da civilização. Mas isto seria absurdo. Os direitos humanos, de primeira ou de segunda dimensão, são formas desenvolvidas, mais elaboradas, do direito comum, e não claridades do entendimento humano.

É preciso estar profundamente embebido na ideologia burguesa para se lastimar a destruição do fenômeno jurídico. O fim do direito nada mais é do que o fim de uma superestrutura a serviço da exploração e da desigualdade. A superação socialista e revolucionária do direito implica a sua substituição por uma sociabilidade interno existente entre a forma jurídica e a forma mercantil" (PASUKANIS, Op. Cit., 1989, p. 28).

${ }^{236}$ PASUKANIS, Op. Cit., 1989, pp. 25-26.

${ }^{237}$ NAVES, Marxismo e direito: um estudo sobre Pachukanis. Op. Cit., 2008, p. 87. 
isenta de fetichismo e alienação. Como sentir "saudades" de um mecanismo social que, como bem disse Marx na crítica ao programa "socialista" de Gotha, "só pode consistir no emprego de uma mesma unidade de medida ${ }^{238}$ " que abstrai as desigualdades operantes?

A recusa à erradicação do direito ocorre numa frente teórico-conceitual e numa frente político-ideológica (ambas entrelaçadas entre si), como se verifica do trecho citado da obra de Márcio Naves. Vejamos o que ocorre.

O senso comum, encabeçado pelo jurista, escandaliza-se com a proposta de uma sociedade que se desenvolva no sentido da extinção do direito. A última coisa que seu cérebro adestrado pela ideologia pode processar é uma organização social para além do direito - pelo mesmo motivo que não consegue processar uma organização para além do capital. O que querem os radicais exaltados? A anomia? O fim da civilização?

O esquema pasukaniano precisa ser compreendido no rigor de suas formulações. A leviandade do jurista médio o leva a julgar apressadamente que, numa sociedade rumo ao comunismo, não haveria nenhuma forma de disciplina e de organização social. Bastar ler atentamente a obra de Pasukanis para que se perceba que o que a derrocada do direito é a derrocada de seus elementos constituintes enquanto fenômeno específico, e não da normatividade em si, embora se deva reconhecer que as normas numa sociedade como esta são de natureza diversa, desde o modo como são concebidas até a sua função na totalidade da reprodução social. Observe-se como o autor soviético aclara o debate:

A dogmática jurídica conclui, então, que todos os elementos existentes na
relação jurídica, inclusive o próprio sujeito, são criados pela norma. Na
realidade, a existência de uma economia mercantil e monetária é
naturalmente a condição fundamental sem a qual todas estas normas
concretas não possuem qualquer significado. É somente sob esta condição
que o sujeito de direito possui um substrato material na pessoa do sujeito
econômico egoísta que a lei não cria, mas que encontra diante de si. Onde
inexiste este substrato, a relação jurídica correspondente é, a priori,
inconcebível ${ }^{239}$.

O fim do direito opera-se, então, pelo fim das condições materiais que ensejam as suas categorias elementares, e nada mais. Não há dúvidas de que, mesmo no comunismo evoluído, a comunidade demandaria regras de convivência.

\footnotetext{
${ }^{238}$ MARX; ENGELS, Manifesto do partido comunista. Op. Cit., 2006, p. 106.

${ }^{239}$ PASUKANIS, Op. Cit., 1989, pp. 63-64.
} 
O ponto central, aqui, é que tais regras definitivamente não seriam jurídicas. $O$ planejamento democrático da produção, escorado em assembleias obreiras, seria claramente um encadeamento de normas, cuja natureza técnica inibiria qualquer traço de direito.

O insistente fetiche do ubi societas, ibi ius é objeto de crítica constante na obra de Pasukanis. Contra ele, o autor propôs a interessante diferenciação entre direito e técnica:

Não podemos contestar que, mesmo entre os animais, existe uma vida coletiva e que esta é regulamentada de uma maneira ou de outra. Mas não ousaríamos afirmar que as relações entre as abelhas e as formigas são regulamentadas juridicamente. Se passamos aos povos primitivos, neles verificamos algumas características de um embrião de direito, mas a maioria das relações é regulada extrajuridicamente, por exemplo, sob a forma de mandamentos religiosos. Finalmente, mesmo na sociedade burguesa, atividades tais como a organização de serviços postais, de estradas de ferro, do exército, etc. só podem ser internamente relegadas ao campo da regulamentação jurídica se as considerarmos muito superficialmente e se não nos deixarmos desconcertar pela forma externa das leis, estatutos e decretos. A planificação ferroviária regula o tráfego nas estradas de ferro em um sentido inteiramente diverso daquele, digamos, que a lei regula sobre responsabilidade das estradas de ferro na entrega de mercadorias transportadas. O primeiro tipo de regulamentação é sobretudo técnico, o segundo basicamente jurídico. A mesma relação existe entre um plano de mobilização e a lei sobre o serviço militar obrigatório, entre a investigação criminal e o código de processo penal ${ }^{240}$.

O critério de diferenciação é, do lado do direito, a oposição de interesses privados; do lado da técnica, a unidade de objetivos:

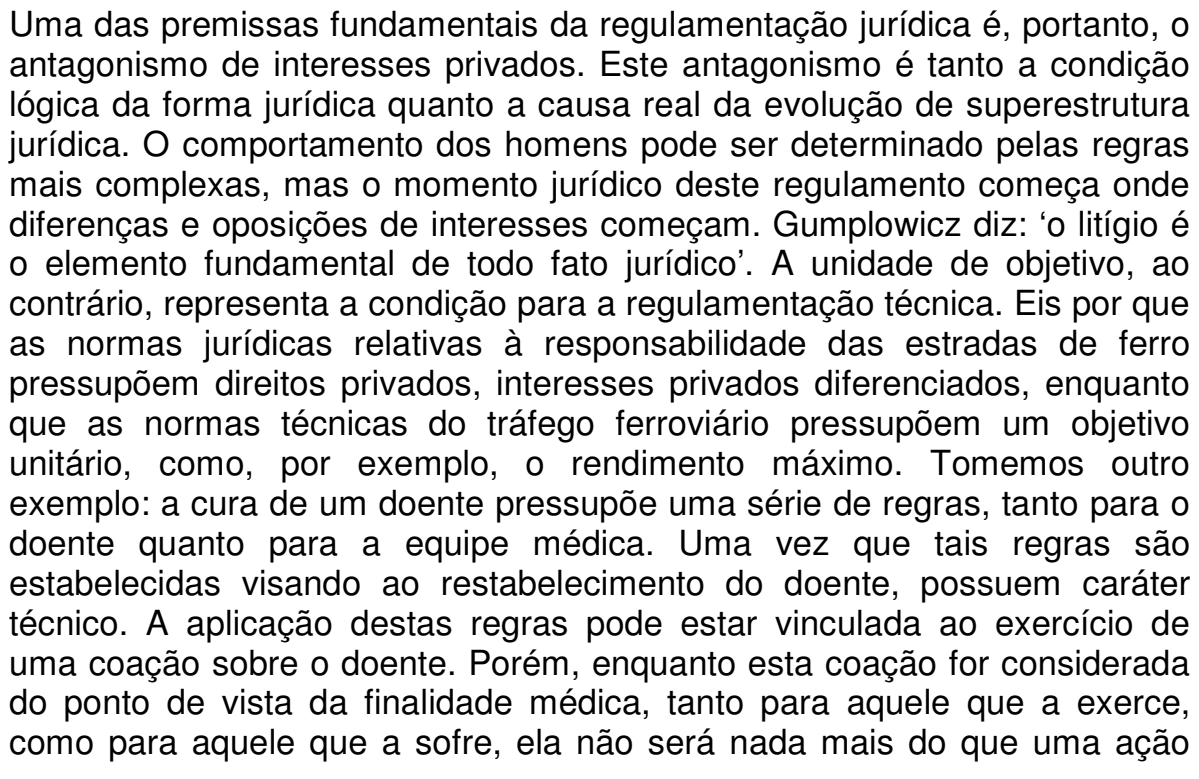

${ }^{240}$ PASUKANIS, Op. Cit., 1989, p. 48 
tecnicamente racional. O conteúdo desta regra é determinado no âmbito da ciência médica e evolui à medida que esta progride. Aqui o jurista nada tem a fazer. A sua tarefa começa onde se é obrigado a abandonar este terreno de unidade de objetivos e assumir outra perspectiva, a perspectiva de sujeitos distintos que se opõem e que possuem, cada qual, seus próprios interesses privados. O doente e o médico transformam-se, então, em sujeitos possuidores de direitos e deveres, e as regras que os unem, em normas jurídicas Destarte, a coação não é mais considerada apenas a partir do ponto de vista da racionalidade do objetivo, mas, igualmente, do ponto de vista de seu caráter formal, quer dizer, juridicamente lícito ${ }^{241}$.

Inúmeras são as possibilidades de disciplina social que escapam às determinações da forma jurídica, sendo que algumas chegam a coexistir com 0 direito burguês. Os prognósticos de caos e anomia não se sustentam, não há razão para histeria.

De outra ordem é a objeção político-ideológica à extinção do direito. A questão aqui não é tanto a dificuldade de se imaginar um mundo sem direito, ou melhor, uma regulamentação social não jurídica ou extrajurídica, e sim o receio de uma sociedade que, ao abolir as categorias jurídicas, afaste com elas a "liberdade" e a "igualdade". É praticamente o anúncio de uma distopia. O mal-estar advém da noção de uma sociedade sem direitos humanos.

Novamente, porém, o conhecimento acurado do marxismo, enquanto método e enquanto programa, proporciona a correta leitura do que está em causa.

\subsection{Liberdade e igualdade no socialismo}

A revolução socialista, ao se aprofundar, aniquila as bases do direito e dos direitos humanos. Nesta incursão, não estaria atentando contra valores como a liberdade e a igualdade?

No que diz respeito à liberdade e à igualdade burguesas, a resposta é afirmativa. Resta saber se outras formas de liberdade e igualdade são cogitáveis, ou se, ao contrário, o socialismo inauguraria um reinado de despotismo e iniquidade ao combater o direito.

O fim da figura do sujeito jurídico carrega com ele a extinção da liberdade e da igualdade enquanto categorias do direito burguês. Isto não quer dizer que a revolução socialista não seja uma empreita libertária e igualitarista. Liberdade e

\footnotetext{
${ }^{241}$ PASUKANIS, Op. Cit., 1989, pp. 50-51.
} 
igualdade no socialismo adquirem uma nova significação, em nítido contraste com aquela que se encontra no capitalismo.

A primeira coisa a se reparar é que, no capitalismo, liberdade e igualdade estão separadas e contrapostas, ao passo que, no socialismo, elas são indissociáveis. Não é por acaso que o liberalismo, doutrina oficial da burguesia, desconfia de qualquer inclinação "coletivista", denunciando-a como despótica:

\begin{abstract}
Os liberais responderam ao desafio socialista asseverando que a luta pela igualdade destruiria, inexoravelmente, a liberdade. Denunciaram a ambição coletivista do igualitarismo como incompatível com o direito à busca individual da felicidade. A premissa da desigualdade natural, inata ou adquirida, condenava logo de saída qualquer projeto igualitarista ao uso da violência contra os mais tenazes ou arrojados. Sendo os homens desiguais, toda tentativa de construir a igualdade social seria artificial, e só poderia ser erguida recorrendo à força do Estado ${ }^{242}$.
\end{abstract}

Uma nuvem de despautérios encobre o debate acerca do socialismo. As superexcitadas imaginações conservadoras apavoram-se com a ideia de um mundo onde o indivíduo seja esmagado. Opiniões, gostos e idiossincrasias seriam brutalmente macerados pela autoridade estabelecida. Nada mais falso. Aliás, esta acusação é suficientemente ingênua para ignorar que o capitalismo, ao alavancar forças até então desconhecidas do intelecto e ao aprofundar a miséria das massas, responde por uma incalculável frustração de talentos individuais. Expliquemos como um rápido raciocínio: os gênios da arte e da ciência são muitos, mas os conheceríamos em número infinitamente maior, e nas mais diversas regiões, caso o pauperismo crônico fomentado pelo capital não privasse populações inteiras de bens essenciais.

É próprio do capitalismo opor a liberdade à igualdade. Esta cisão aparece na superestrutura jurídica como uma necessidade de ponderação entre princípios. Marcus Orione Gonçalves Correia explica:

Aqui, entende-se por que alguns preferem fazer uma leitura dicotômica da igualdade em relação à liberdade. Ao se colocar em lados opostos igualdade e liberdade, fica muito mais fácil à lógica capitalista a sua própria consolidação. Um capitalismo, em que igualdade e liberdade, e acrescento aqui, solidariedade, fossem postas lado a lado, certamente seria muito difícil - senão impossível - de concretizar.

No direito, por exemplo, certamente que os postulados que fundamentam qualquer lógica de ponderação não teriam condições de vigorar. Aliás, a ponderação de princípios é a clara expressão de que o direito somente se

${ }^{242}$ ARCARY, Op. Cit., 2006, p. 284. 
dá onde uma liberdade, sem igualdade e solidariedade consideradas em conjunto, supere outra liberdade.

Aliás, aqui gostaria de ressaltar que toda ponderação de princípios, na realidade, esconde um único conflito existente no sistema (tanto capitalista, quanto jurídico): uma colisão de liberdades e de igualdades ${ }^{243}$.

E não poderia ser diferente sob o domínio do modo de produção capitalista, um sistema que, ao constituir as pessoas em sujeitos guardiões de mercadorias, em proprietários ensimesmados, lançou a humanidade no aviltante "cada um por si" do individualismo burguês. Lembremos das citações d'A Questão Judaica ${ }^{244}$, onde já se advertia que os direitos humanos ofereciam ao indivíduo uma liberdade que esbarrava na do outro indivíduo.

Ao "homem versus homem", corresponde a fórmula "liberdade versus igualdade". O único igualitarismo aceito (e até exigido) pelo capitalismo é a isonomia legal, o igual tratamento pela lei. Este tipo de igualdade não ofende a liberdade burguesa, já que se trata de uma igualdade que não ameaça a propriedade privada. Ela é, antes, um pressuposto.

Entende-se, por esta cisão, porque as classes dominantes e seus representantes são dotados de uma sensibilidade extraordinária. Entende-se, afinal, como uma suave crítica às "imperfeições" do mercado é capaz de enervar nossos bons liberais. O desabafo do espirituoso Dom Helder Câmara é revelador: "Quando dou comida aos pobres, me chamam de santo. Quando pergunto por que eles são pobres, chamam-me de comunista".

O acesso universal e igualitário às benfeitorias da civilização não é um atentado à liberdade, como imaginam os liberais. No máximo, é um atentado à liberdade burguesa. Os socialistas, em sentido oposto, advogam que o acesso universal e igualitário às mencionadas conquistas, que só pode ser obtido pelo comando da produção pelo proletariado, é condição da liberdade, e não um obstáculo.

Para conciliar liberdade e igualdade, os socialistas reinventaram o significado destas aspirações. Quando os marxistas invocam liberdade e igualdade, emprestam a estas palavras uma conotação muito diversa daquela que se acha na mente dos liberais. Novamente, Valério Arcary mostra o caminho:

${ }^{243}$ CORREIA, Marcus Orione Gonçalves. O conflito de princípios e as falácias da liberdade. Revista TRF 3.. Região, São Paulo, n. 107, pp. 48-55, maio e jun./2011, p.51.

${ }^{244} \mathrm{O}$ assunto foi explorado há dois capítulos atrás. 


\begin{abstract}
A igualdade social - uma relação dos homens entre si - tem como premissa, portanto, o acesso à abundância para todos. $\mathrm{E}$ a liberdade humana - uma relação dos homens com a natureza - tem como premissa a satisfação das necessidades de todos. São um único e mesmo conceito que se desdobra em dois, se estabelecemos a relação dos homens entre si na sociedade ou com a natureza. Liberdade e igualdade seriam, portanto, inseparáveis e estariam historicamente condicionadas pela possibilidade da fartura, ou seja, pela capacidade social de gerar uma produção econômica que pudesse satisfazer às necessidades mais intensas de todos. Para serem iguais entre si, os homens precisariam ser capazes de se emancipar da penúria ou, em outras palavras, libertar-se da opressão da natureza, desenvolvendo as forças produtivas para além das limitações materiais e culturais herdadas do passado ${ }^{245}$.
\end{abstract}

A igualdade, para os marxistas, não é a equivalência formal e jurídica entre as pessoas, assim como não é uma distribuição igual de "oportunidades", para que os indivíduos se lancem à luta pela vida num jogo mais "equilibrado". Ela é, isto sim, a satisfação igual e universal das necessidades, o que pressupõe a extinção das classes sociais e da exploração. A igualdade como equivalência subsiste apenas num momento inicial do socialismo. Do mote socialista, "de cada um segundo sua capacidade, a cada um segundo seu trabalho", avança-se para o mote comunista, "de cada um segundo sua capacidade, a cada um segundo suas necessidades". O último resquício da equivalência jurídica cai por terra.

Acerca da igualdade, em particular, a ponderação de Engels é indispensável, demonstrando que, "intuitivamente", o proletariado clama pelo fim das classes sociais, o que se dá, historicamente, por mediações ideológicas que, apesar de ideológicas (consciências "distorcidas"), autorizam que se entreveja o potencial emancipatório dessa classe:

Desde o instante em que se proclama o postulado burguês da abolição dos privilégios de classe, ergue-se o postulado proletário da abolição das próprias classes, postulado êsse que adota primeiro a forma religiosa, baseada no cristianismo primitivo, e que, mais tardem se apóia nas próprias teorias burguesas da igualdade. Os proletários colhem a burguesia pela palavra: é preciso que a igualdade exista não só na aparência, que não se circunscreve apenas à órbita do Estado, mas que tome corpo e realidade, fazendo-se extensiva à vida social e econômica. (...)

O postulado da igualdade tem, pois, na bôca do proletariado, uma dupla acepção. Às vezes - como sucedeu sobretudo nos primeiros tempos, na guerra dos camponeses, por exemplo, - êste postulado significa a reação natural contra as desigualdades sociais clamorosas, contra o contraste entre ricos e pobres, senhores e servos, famintos e glutões. Êste postulado da igualdade não é mais que uma explosão do instinto revolucionário e somente isso é que o justifica. Outras vêzes, no entanto, nasce êsse postulado como reação contra o postulado de igualdade da burguesia e tira

\footnotetext{
${ }^{245}$ ARCARY, Op. Cit., 2006, p. 288.
} 
dêle muitas conseqüências avançadas, mais ou menos exatas, sendo utilizado como meio de agitação para levantar os operários contra os capitalistas, usando para isso frases tomadas dos próprios capitalistas e, considerado dêsse aspecto, se organiza e cai por terra êsse postulado juntamente com essa mesma liberdade burguesa. Tanto num como noutro caso, o verdadeiro conteúdo do postulado da igualdade proletária é a aspiração de alcançar a abolição das classes. Qualquer outra aspiração de igualdade que transcenda a tais limites desborda, necessariamente, para o absurdo $^{246}$.

No tocante à liberdade, recorremos novamente à explicação de Engels, agora numa outra obra:

Ao apossar-se a sociedade dos meios de produção, cessa a produção de mercadorias e, com ela, o domínio do produto sobre os produtores. A anarquia reinante no seio da produção social cede o lugar a uma organização planejada e consciente. (...) As condições que cercam o homem e até agora o dominam, colocam-se, a partir desse instante, sob o seu domínio e seu comando, e o homem, ao tornar-se dono e senhor das suas próprias relações sociais, converte-se pela primeira vez em senhor consciente e efetivo da natureza. (...) Só a partir de então, ele começa a traçar a sua história com plena consciência do que faz. E só daí em diante as causas sociais postas em ação por ele começam a produzir predominantemente, e cada vez em maior medida, os efeitos desejados. É o salta da humanidade do reino da necessidade para o reino da liberdade ${ }^{247}$.

Os liberais, diante destas definições, argumentariam que os marxistas não levam em conta as liberdades democráticas, e que se contentariam com um regime que, a despeito de seus abusos e desmandos, abastecesse as massas com mantimentos, instrução e recreação. Que a cobertura das necessidades exigiria, em contrapartida, a escravização do povo pela chamada "ditadura do proletariado". Uma ditadura preconizada e celebrada Karl Marx em pessoa, não havendo, então, nenhum desvio stalinista!

O que é a ditadura do proletariado? Decerto que a palavra "ditadura", aqui, não está imbuída da carga pejorativa que lhe é dada nos dias atuais. Podemos supor com alguma segurança que o fundador do materialismo histórico-dialético a pegou emprestada do jacobinismo, que, a seu tempo, a invocou em remissão à antiga república romana. Nesta acepção, a ditadura não é um regime opressivo e despótico, e sim um governo de exceção instaurado para enfrentar uma crise institucional aguda. Seria um governo de "salvação nacional", uma medida

\footnotetext{
${ }^{246}$ ENGELS, Op. Cit., 1990, pp. 89-90.
}

247 ENGELS, Friedrich. Do socialismo utópico ao socialismo científico, $8^{a}$ ed.. Tradução de Armandina Venâncio. São Paulo: Global editora, 1986, pp. 76-77. 
republicana de emergência. Por óbvio, há um desconforto inerente deste conceito em relação ao que se espera de um governo revolucionário da classe proletária, cuja condução estaria atrelada ao objetivo de expropriação da burguesia e de transformação da base econômica até então estabelecida.

A escolha da palavra "ditadura", ao que parece, deve-se à centralidade do elemento de emergência citado, ao estado de exceção que se inaugura, no qual o jogo político segue desregradamente. Por outro lado, o conceito marxista de Estado envolve sempre a existência de classes e a dominação política de uma sobre a outra. Nesta perspectiva, qualquer Estado exerceria seu poder por uma espécie de ditadura ${ }^{248}$.

Mas basta de especulações. A discussão sobre o nome do regime operário é de pouca utilidade e, até certo ponto, secundária. Como dizia Marx, "O nome de uma coisa é extrínseco às suas propriedades. Nada sei de um homem por saber apenas que se chama Jacó ${ }^{249, "}$.

A fim de conhecer a ditadura do proletariado, cumpre nos reportarmos às suas manifestações reais ao longo da história. O rosto desta forma política "enfim encontrada" foi a Comuna de Paris ${ }^{250}$.

A Comuna iniciou um processo de destruição do Estado capitalista na capital francesa, sendo detida apenas por uma repressão sanguinária. Nela, o aparelho repressivo do Estado foi desmantelado, colocando-se, no lugar do exército e da polícia, o proletariado em armas. A administração foi entregue a organismos operários, extinguindo-se os privilégios burocráticos. O resumo das mudanças está em Marx:

\footnotetext{
${ }^{248}$ Conferimos esta posição com Poulantas no capítulo primeiro. Em acréscimo, reproduzimos os dizeres de Márcio Naves: "O Estado que a classe operária constitui após a tomada do poder é, para Marx, uma ditadura, a ditadura do proletariado. Não nos enganemos quanto aos termos: ele entende que todo Estado é uma ditadura, na medida em que ele é a forma política de dominação de uma classe. Assim, um Estado poder ser 'democrático', isto é, ele pode admitir um certo grau de liberdades públicas, o parlamento e o sufrágio universal, e nem por isso deixar de ser uma ditadura, porque o poder político continua a ser exercido pela classe dominante. Ao contrário da ditadura burguesa - que é a ditadura de uma minoria, em favor dessa minoria - a ditadura do proletariado é uma ditadura exercida pela maioria, pelos trabalhadores, contra a antiga classe dominante" (NAVES, Marx: Ciência e Revolução, Op. Cit., 2008, pp. 134-135).

${ }^{249}$ C., I, I, p. 128.

250 "O filisteu socialdemocrata caiu recentemente, outra vez, em salutar terror, ao termo: ditadura do proletariado. Bem, senhores, quereis saber que rosto tem essa ditadura? Olhai para a Comuna de Paris. Era a ditadura do proletariado". Foram esses os dizeres de Friedrich Engels na sua introdução ao texto "A Guerra Civil na França", de Karl Marx. Ver em MARX, A revolução antes da revolução, Op. Cit., 2008, p. 355. Acrescentamos que revoluções como a russa e a chinesa, antes de degenerarem, igualmente propiciaram ditaduras do proletariado.
} 


\begin{abstract}
A Comuna foi formada por conselheiros municipais, eleitos por sufrágio universal nos vários bairros da cidade, responsáveis e revogáveis em qualquer momento. A maioria dos seus membros eram naturalmente operários ou representantes reconhecidos da classe operária. A Comuna havia de ser não um corpo parlamentar, mas operante, executivo e legislativo ao mesmo tempo. Em vez de continuar a ser o instrumento do governo central, a polícia foi logo despojada dos seus atributos políticos e transformada no instrumento da Comuna, responsável e revogável em qualquer momento. $\mathrm{O}$ mesmo aconteceu com os funcionários de todos os outros ramos da administração. Dos membros da Comuna para baixo, o serviço público tinha de ser feito em troca de salários de operários. Os direitos adquiridos e os subsídios de representação dos altos dignitários do Estado desapareceram com os próprios dignitários do Estado ${ }^{251}$.
\end{abstract}

Que pensar desta "ditadura", se comparada à "democracia" liberal? Qual das "avançadas" e "civilizadas" potências democráticas do Ocidente estende a seus cidadãos alguma participação política desta profundidade? $\mathrm{O}$ contraste com a Comuna revela que a democracia dos liberais é obstáculo, e não caminho, para a participação popular nos assuntos públicos. Aliás, o que se assiste em diversos países agora é um contínuo processo de pilhagem, deveras "democrático" e "liberal", dos tesouros nacionais pela aristocracia do capital financeiro fragilizado pela crise, uma drenagem de recursos que adota, por contrapartida, severos ajustes fiscais que anulam garantias sociais elementares. Acaso os trabalhadores europeus foram consultados quanto a isto nos seus regimes ditos democráticos? Não, há que se aguardar as eleições para que a vontade da maioria se exerça por mecanismos legítimos! Até lá, cabe ao povo contemplar, com estoica resignação, o desmoronamento da antiga muralha welfarista sobre sua cabeça. Eis aí uma postura "democrática", pois se o proletariado destronasse os capitalistas, interrompe-se o parasitismo crônico do rentismo financeiro e alocasse os recursos públicos para abastecer as demandas da população, estaríamos diante de uma atitude "autocrática" e "ditatorial". Tal é o raciocínio dos liberais, representantes oficiais das classes confortáveis.

Numa visão marxista, não há como se tolerar uma ação estatal nos moldes da "ditadura/democracia" da burguesia, que impõe medidas extorsivas às massas. $\mathrm{Na}$ ditadura do proletariado, e a Comuna de Paris assim confirma, o Estado não é uma autoridade estranha ao povo, não é um ente que impõe sua dominação. $O$ Estado operário, fruto da revolução, deve estar em "definhamento" constante. Ele existe apenas, e rigorosamente, para despossuir a burguesia e para organizar a luta dos

${ }^{251}$ MARX, A revolução antes da revolução, Op. Cit., 2008, p. 402. 
trabalhadores contra ela. E quanto mais avança neste propósito, mais ele perde a sua razão de ser:

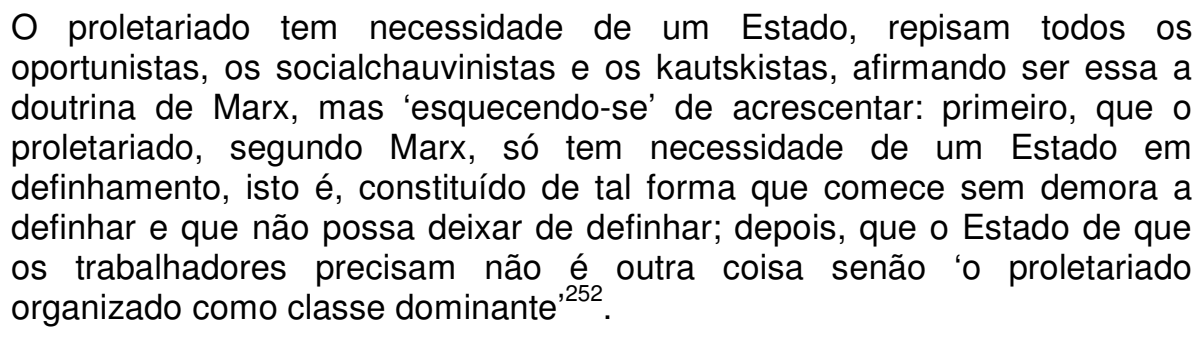

E a fim de realizar este desiderato, o Estado operário, diz Lênin, "deve ser, pois, um Estado democrático (para os proletários e os não-possuidores em geral) inovador e um Estado ditatorial (contra a burguesia) igualmente inovador ${ }^{253}$ ". Sua missão é armar a maioria explorada com os meios necessários para derrotar a minoria exploradora, até que se apague da face da Terra esta erva daninha chamada exploração.

Nisto consiste a ditadura do proletariado.

\footnotetext{
${ }^{252}$ LENIN, O Estado e a revolução: o que ensina o marxismo sobre o Estado e o papel do proletariado na revolução, Op. Cit., 2007, pp. 42-43. O trecho traz, ainda, novo indício de que a URSS não responde pelo socialismo. Bem ao contrário de um definhamento, o Estado daquele país se agigantou, convertendo-se num Moloch insaciável.

${ }_{253}$ LENIN, O Estado e a revolução: o que ensina o marxismo sobre o Estado e o papel do proletariado na revolução, Op. Cit., 2007,p. 53.
} 


\title{
6. CONCLUSÃO
}

\begin{abstract}
Méfions-nous de l'utilisation des droits de l'homme! Si, dans un premier temps, et pour un court instant, ils peuvent constituer une base de lutte, si, en un sens, l'extension de ces droit aux travailleurs peut réaliser un "progrès", ce "progrès" emporte ses propres limites. Car, la revendication d'égalité qui ne quitte pas le terrain du droit, ne peut aller au-delà de l'égalité juridique, donc des rapports de production capitalistes ${ }^{254}$.
\end{abstract}

Enfim, após um longo trajeto, já é tempo de expormos nossas últimas reflexões sobre o tema.

Nosso exame do fenômeno jurídico apontou sua origem burguesa e sua inserção no modo de produção capitalista, em que ele se espraia da circulação mercantil para outros ramos de relações sociais. Os direitos humanos aparecem neste movimento, carregando com eles a marca indelével da mercadoria, ou melhor, do indivíduo abstrato que a conduz ao mercado.

Na dita primeira dimensão dos direitos humanos, que raiou, não por acaso, concomitantemente ao sistema capitalista de produção, as determinações capitalistas estão imediatamente colocadas. O "homem" das declarações de direitos foi feito com a mesma argamassa que a burguesia, e pelas mesmas mãos. As liberdades democráticas esboçadas naqueles elegantes documentos limitam-se a acomodar (e não sem atritos e reviravoltas) a luta de classes a um regramento que alivia a fúria de sua torrente, esforçando-se para que o "homem" não se transfigure em burguês ou proletário. O Estado de direito, a forma com que os capitalistas exercem sua dominação na normalidade, é uma máquina que, operando as mencionadas liberdades, favorece a burguesia em duas frentes: exercendo o monopólio da violência de maneira calculável, adequada aos negócios, e encarcerando a política na cela parlamentar; ou, em caráter subsidiário, tolerando um "regime semiaberto", em que os insatisfeitos fazem sua crítica respeitando a "ordem pública", as instituições, a "paz social" etc. O direito de manifestação do descontente esbarra numa multiplicidade de outros direitos. Ser-lhe-ia mais sensato ficar em casa, despido de sua pertença a uma classe, e aguardar o desenrolar das

\footnotetext{
${ }^{254}$ EDELMAN, Op. Cit., 1978, p. 91. Em português: "Desconfiemos da utilização dos direitos humanos! Se, num primeiro momento, e por um curto instante, eles podem constituir uma base de luta, se, num sentido, a extensão desses direitos aos trabalhadores pode realizar um 'progresso', este 'progresso' carrega seus próprios limites. Pois a reivindicação de igualdade que não abandona o terreno do direito não por ir além da igualdade jurídica e, portanto, das relações de produção capitalistas".
} 
eleições. E se o Estado de Direito não for muito convincente, a razão de Estado pode deixar de lado a legalidade, temporariamente ou em definitivo, para acalmar os ânimos dos mais exaltados.

Os encantadores direitos humanos, destinados a exprimir uma razão universal, destinados a abençoar todos os homens, fracassaram, afirmam-nos os juristas progressistas. Esses direitos, reconhecendo humildemente seu fracasso e carecendo de complementação, deram a si mesmos uma nova oportunidade, pelo que nos contam. A segunda chance foi apelidada de segunda dimensão dos direitos humanos - os direitos sociais.

O capitalismo, algo amadurecido, repensou os excessos do frescor de sua juventude. Conjuntamente com o próprio direito, considerou o liberalismo clássico como uma aventura que não deveria ser revivida em sua total intensidade. A prudência o exige, dado que o corpo não é mais o mesmo quando se alcança certa idade. E foi assim que surgiu o "social".

$\mathrm{Na}$ sua estreia e ainda na atualidade, o "social" exerce um fascínio incomensurável sobre a classe operária e sobre a intelectualidade. A maioria não percebeu a continuidade do individualismo da forma jurídica burguesa nos direitos sociais. Não compreendeu que até a mais abrangente rede de seguridade social carrega consigo o pecado original da equivalência jurídica, do amesquinhamento das relações sociais à semelhança da forma mercantil. Não entendeu que a mais meticulosa e exigente das legislações trabalhistas incide sobre um contrato em que o aviltamento está dado na própria contratação, que encobre a extração da maisvalia, e não apenas nas suas cláusulas. Não decodificou, dentro das ramificações dos direitos sociais, a armadilha do direito coletivo do trabalho, que é, ao fim e ao cabo, terreno do inimigo. Pior: acreditou que havia encontrado a "estrada de Damasco" da forma jurídica!

E há mais. O oferecimento, pelo Estado, de serviços de educação, seguridade social, moradia etc., não é nenhum indício de superação do capital. Pelo contrário: o nível de intervenção do Estado na reprodução econômica, que aqui se afigura como reprodução da força de trabalho, não depende da evolução autodidata do direito ou do aperfeiçoamento do espírito humano, imbuído de um coração mais brando após a industrialização capitalista. Ele depende das relações entre as classes antagônicas num dado instante histórico, ou seja, de uma correlação de forças momentânea, e das necessidades de acumulação apresentadas pelo próprio capital. Esta é a razão 
pela qual o Welfare State (Requiescat in pace!) foi uma exceção no tempo e no espaço. Como é amplamente conhecido, não sobreviveu ao descenso operário e aos rearranjos da financeirização e da acumulação flexível.

Nos dois primeiros capítulos, portanto, submetemos os direitos humanos e sociais a uma crítica ferrenha e radical.

O jurista progressista, ao se deparar com o percurso descrito, tende a se revoltar. Com algum esforço, conseguimos até imaginá-lo suspirando "à la Luís XV": "Après le droit le déluge"! Uma paráfrase que, descontando-se nossa incorrigível ironia, sumariza a angústia de quem entregou suas esperanças aos direitos humanos. Com o coração partido e os pensamentos em desalinho, nosso personagem perambularia por um desértico e monótono vale de lágrimas, munido apenas de "duas mãos" e do "sentimento do mundo", para usarmos a linguagem de Drummond. Criticar o direito é uma coisa, mas os direitos humanos? O que sobra então?

Se o jurista enveredar por esse caminho de desalento, que não nos culpe, já que tivemos o cuidado de dedicar algumas páginas de estudo a um projeto alternativo. Diferenciamos este projeto da corrompida União Soviética de Stálin e demonstramos a necessidade de se refundar a sociedade, de se reorganizar as suas bases materiais. Evidentemente, não perdemos a oportunidade de deixar claro que o direito não é um instrumento apto a este fim. $E$, como se não bastasse, acalentamos os ideais do jurista com novas (e marxistas) formas de se buscar liberdade e igualdade ${ }^{255}$. Tudo isso dentro das limitações de nosso tema e das leituras e conhecimentos que tínhamos à disposição.

Eis a síntese da ópera.

Nossos interlocutores progressistas, chocados com a perspectiva que adotamos, poderão indagar acerca da pertinência de uma crítica dos direitos humanos em tempos de neoliberalismo. Retrucamos com uma frase que resume nossa primeira conclusão: a crítica dos direitos humanos é a crítica do direito, da

\footnotetext{
${ }^{255}$ Registramos aqui nossa discordância com Mészáros quando diz que "os direitos humanos de 'liberdade', 'fraternidade' e 'igualdade' são, portanto, problemáticos, de acordo com Marx, não por si próprios, mas em função do contexto em que se originam, enquanto postulados ideais abstratos e irrealizáveis, contrapostos à realidade desconcertante da sociedade de indivíduos egoístas" (MÉSZÁROS, István. Filosofia, ideologia e ciência social: ensaios de negação e afirmação. Tradução de Ester Vaisman. São Paulo: Boitempo, 2008, p. 161). Em contraste com o que afirma o autor, constatamos que os direitos humanos são burgueses pela sua derivação da forma jurídica e mercantil. A crítica de Marx cabe não porque esses direitos sejam "irrealizáveis" em sua extensão absoluta, mas sim pela maneira capitalista como se realizam.
} 
forma jurídica; e a crítica da forma jurídica comporta nela a crítica do capital. A radicalidade do método marxista conduz-nos a uma inquirição cada vez mais a fundo, da qual não é certo que nos furtemos por razões de "conveniência conjuntural".

Enganam-se redondamente, contudo, se esperam encontrar algum legítimo revolucionário fazendo coro ao Consenso de Washington e aos ataques à classe proletária desferidos no âmbito jurídico. Equivocam-se se esperam resignação dos socialistas neste campo. Os socialistas batalham intransigentemente pelos direitos básicos da classe obreira (ao contrário dos reformistas, especialistas na arte de fazer concessões ao empresariado), bem como pelas liberdades democráticas necessárias a este enfrentamento. A diferença está na postura perante o direito, um dos elementos de divisão entre reformistas e revolucionários.

Essa divisão existe, querendo-se ou não. Nosso trabalho acabou revolvendo a ferida oriunda desta cisão na esquerda, abrindo um novo front. Iniciamos pelo combate ao conservadorismo liberal tradicional, e eis que o fogo de nossas baterias estendeu-se a território "aliado".

Com que finalidade optamos por criticar os reformistas, se eles dividem, com os revolucionários, as escassas fileiras da esquerda? Com que objetivo polemizamos com autores que contribuíram e contribuem para a defesa dos interesses imediatos dos trabalhadores? E, já que o fizemos, como justificar a intensidade da luta empenhada?

É que os revolucionários caminham com os reformistas apenas até certo ponto. Além dele, interrompem-se os canais de diálogo. Num dado instante, a defesa do reformismo deixa de ser uma mera autolimitação de horizontes e degenera em defesa do capitalismo. E pior: diversos trabalhadores são levados a crer que o capitalismo é passível de emendas que o dignifiquem, e que o direito seria o remédio ideal.

Os reformistas não estão errados quando postulam que os direitos humanos representam melhoras para as classes populares, e é altamente admirável o engajamento de alguns autores que criticamos neste sentido. A crítica que lhes dirigimos não é contra as reformas, no âmbito jurídico, pelas quais se empenham, e sim contra a ilusória crença no direito como ferramenta redentora. Campanhas pela redução da jornada de trabalho e pelo fim da criminalização dos movimentos sociais, 
apenas para citar alguns exemplos, são elogiáveis e necessárias ${ }^{256}$. Nosso inconformismo é destinado, que fique claro, à ideia falsa de que o direito seja determinante nestes avanços, e que estes mesmos avanços, ao se exprimirem juridicamente, lancem luz sobre uma estrada para a emancipação até então ignorada ou desdenhada.

Não duvidamos que o fardo do capital sobre o trabalho seria mais leve se os juristas progressistas existissem em quantidade superior. A questão é: isto basta? $\mathrm{E}$ até quando? Convidamos o reformismo jurídico a se indagar se o que falta ao mundo são mais advogados, juízes e promotores de esquerda, ou, diferentemente, se faltam organizações do operariado que conspirem permanentemente contra o capitalismo, que preparem a classe para os embates com o capital e que, casualmente, recorram a alguns aliados táticos. Quanto a nós, já adiantamos que não podemos aquiescer com promessas irrealizáveis que alimentem ilusões numa ideologia burguesa, entorpecendo a razão e cerceando o livre agir do proletariado.

E é pela magnitude do que está em jogo que nos entregamos às polêmicas com dedicação e espírito militantes, conscientemente. Que nossos interlocutores aliados nos perdoem pelo calor de nossas considerações e por nossas figuras de linguagem não represadas nos instantes de discordância. Nossas exacerbações atribuem-se ao fato de que não se discute o destino do movimento operário por mero diletantismo. Não é admissível, aqui, a dissociação entre a busca da interpretação e a busca da transformação ${ }^{257}$. Não nos dispusemos a uma análise marxista dos direitos humanos apenas para nos comprazermos com a superioridade metodológica do materialismo histórico-dialético sobre o idealismo jurídico. Anunciamos nosso intuito já na introdução: diagnosticar os horizontes reformistas de aposta estratégica no direito, e nos direitos humanos em especial. Esta é uma preocupação claramente militante.

Os reformistas nos perguntam: o que dizer, afinal, dos direitos humanos?

\footnotetext{
${ }^{256}$ O uso tático das reformas sociais pelo seu conteúdo de agitação, subordinado a uma estratégia socialista que alia o nível de consciência das massas às necessidades objetivas do movimento operário, de modo a compor um programa político de catarse e ruptura rumo ao socialismo, foi engenhosamente elaborado por Trotsky. Confira-se uma de suas obras de maior repercussão: TROTSKY, Leon. O programa de transição para a revolução socialista. Tradução de Elisabeth Marie e Luiz Gustavo Soares. São Paulo: Instituto José Luís e Rosa Sundermann, 2008.

257 "Os filósofos interpretaram o mundo de diferentes maneiras; o que importa é transformá-lo" (MARX; ENGELS, A ideologia alemã: crítica da mais recente filosofia alemã em seus representantes Feuerbach, B. Bauer e Stirner, e do socialismo alemão em seus diferentes profetas. Op. Cit., 2007, p. 535.).
} 
Respondemos: estão entre as realizações mais elevadas logradas no interior do capitalismo, portando em seu bojo diversas lutas históricas, todas elas respeitáveis e decisivas.

Mas não só. Dizemos ainda: essas realizações, no entanto, são lírios colhidos de um pântano enorme. Elas surgiram de um sistema que acumula capital com a única finalidade de acumular mais capital (obedecendo cegamente à tautologia infernal da lei do valor), e que, ao fazê-lo, condena milhões à indigência, à exploração e a outras formas de miséria. E elas somente poderiam eclodir neste sistema. Nem antes e nem depois.

Os lírios são belos e exuberantes. Mas um lírio não é apenas as pétalas e o caule. Não tem ele uma raiz? E se esta raiz está escondida no lamaçal do pântano, não partilha ela da essência do domínio em que foi fecunda?

Esta é a verdade, por mais "dolorosa" que seja. O charme dos lírios não os exime: eles são uma extensão do pântano. Os direitos humanos, em suas diferentes dimensões, são uma extensão do capitalismo. Prova disto está na epígrafe de Edelman: qualquer reivindicação que não ultrapassa o jurídico terreno dos direitos humanos está fadada a se compor com o capital, a consentir com a sua reprodução perpétua.

Se fizemos questão de escrever um capítulo sobre o socialismo científico, foi para declarar que os direitos humanos não devem ser o horizonte último da civilização. Os socialistas almejam o fim dos direitos humanos, dada a sua insuficiência e a sua relação íntima com o capital, mas com a condição de que sejam suplantados por uma nova forma de sociabilidade, capaz de propiciar a abolição das classes sociais e de todas as aflições resultantes desta divisão entre os homens.

Por certo, nossa leitura não colide somente com o reformismo clássico. Não faltarão autores marxistas para criticar nossos "exageros". Alertar-nos-ão dos perigos em que incorremos e da improdutividade deste ceticismo. Afinal, não seria aceitável dizer que o direito "não serve para nada". Esta resposta estaria excluída a priori por ser indesejável.

Destarte, cabe-nos especificar: ceticismo resoluto em relação ao direito como instrumento de transformação? Sim, somos réus confessos quanto a isto, e acreditamos que o marxismo não permita outra conclusão.

Daí não se infere, contudo, que este ceticismo redunde em fatalismo. Por sua própria dialética, o marxismo está ciente de que o operariado não está condenado a 
pena perpétua de capitalismo. Não que este modo de produção possa "cair de maduro", ruindo catastroficamente ${ }^{258}$. Por outro lado, a existência de classes implica a luta de classes, e a luta implica um resultado em aberto, uma história inacabada (ou jamais iniciada propriamente, para Marx).

Esperança não nos falta. A diferença é que, ao invés de desperdiçá-la com o direito, aplicamo-la ao movimento de massas e às suas organizações mais radicais, engajadas na estratégia socialista e atentas aos estratagemas das frequentes reedições do socialismo jurídico. Esta é aposta que nos parece condizente, de fato, com o legado do marxismo.

É óbvio que o uso eventual dos direitos humanos, mesmo fora dos marcos da agitação política, dificilmente comprometeria uma estratégia revolucionária consciente e prevenida dos perigos do direito. Uma organização que se recusasse a acionar o Judiciário para tentar, via habeas corpus, libertar um ativista detido - o que não exclui campanhas de mobilização e solidariedade, ou outras formas de intervenção mais eficazes -, certamente não iria muito longe se sua recusa repousasse num capricho "purista". O que importa é dar o devido tratamento ao direito. Abandoná-lo por princípio, sem qualquer avaliação conjuntural, sem estudar as chances de um uso restrito, "homeopático", com ressalvas mil, seria um erro infantil. O erro simétrico, qual seja, idolatrá-lo, confiar a ele os sonhos de uma geração, acomodar-se a ele, assimilar o seu modus operandi conservador, é tão ruim quanto, ou até pior.

Concluindo, acreditamos que o correto seja postar-se perante o direito com o desprezo idêntico ao que Brás Cubas, impagável figura machadiana, reservava a seu leitor. Se, na eventualidade da situação concreta, e com estrita parcimônia, o direito puder ser de alguma utilidade à classe trabalhadora, muito que bem. Caso contrário - e esta é a imensa maioria das ocasiões -, "um piparote e adeus"!

E se o jurista, inconformado com tudo o que vimos, insistir no seu "messianismo jurídico", lembremos da firme advertência marxiana, inabalavelmente materialista e dialética: "O direito jamais pode ser mais elevado do que a estrutura econômica da sociedade e o desenvolvimento cultural correspondente ${ }^{259, "}$.

\footnotetext{
258 "O capitalismo nunca vai cair por si próprio. Terá de ser empurrado. A acumulação do capital nunca vai cessar. Terá de ser interrompida. A classe capitalista nunca vai entregar voluntariamente seu poder. Terá de ser despossuída" (HARVEY, Op. Cit., 2011, p. 209).

${ }^{259}$ MARX; ENGELS, Manifesto do partido comunista. Op. Cit., 2006, p. 107. A assertiva está contida na crítica ao programa de Gotha.
} 


\section{REFERÊNCIAS BIBLIOGRÁFICAS}

AGAMBEN, Giorgio. Estado de exceção, 2.. ed.. Tradução de Iraci D. Poleti. São Paulo: Boitempo, 2007.

ALAPANIAN, Silvia. A crítica marxista do direito: um olhar sobre as posições de Evgeni Pachukanis. In: NAVES, Márcio Bilharinho (org.). 0 discreto charme do direito burguês: ensaios sobre Pachukanis. Campinas, SP: UNICAMP, Instituto de Filosofia e Ciências Humanas, 2009.

ALTHUSSER, Louis. A favor de Marx, 2. a ed.. Tradução de Dirceu Lindoso. Rio de Janeiro: Zahar, 1979.

Aparelhos ideológicos de Estado: nota sobre os aparelhos ideológicos de Estado. Tradução de Walter José Evangelista e Maria Laura Viveiros de Castro. São Paulo: Graal, 2007.

ANTUNES, Ricardo. Adeus ao trabalho: ensaio sobre as metamorfoses e a centralidade do mundo do trabalho, $12^{\mathrm{a}}$ ed.. São Paulo: Cortez; Campinas, SP: Editora da Universidade Estadual de Campinas, 2007.

ARCARY, Valério. O encontro da revolução com a história: socialismo como projeto na tradição marxista. São Paulo: Instituto José Luís e Rosa Sundermann; Xamã, 2006.

Um reformismo quase sem reformas: uma crítica marxista do governo Lula em defesa da revolução brasileira. São Paulo: Instituto José Luís e Rosa Sundermann, 2011.

BALIBAR, Étienne. Sobre os conceitos fundamentais do materialismo histórico. In: ALTHUSSER, Louis (org.). Ler O capital: vol. II. Tradução de Nathanael C. Caixeiro. Rio de Janeiro: Zahar, 1980.

BATISTA, Flávio Roberto. Crítica da tecnologia dos direitos sociais: uma contribuição materialista histórico-dialética. Tese (doutorado). São Paulo: USP, 2012. 
BERCOVICI, Gilberto. Soberania e constituição: para uma crítica do constitucionalismo. São Paulo: Quartier Latin, 2008.

BETTELHEIM, Charles. A luta de classes na União Soviética: primeiro período (1917-1923), 2. a ed.. Tradução de Bolívar Costa. Rio de Janeiro: Paz e Terra, 1979.

BETTELHEIM, Charles; CHAVANCE, Bernard. O stalinismo como ideologia do capitalismo de Estado. In: NAVES, Márcio Bilharinho (org.). Análise marxista e sociedade de transição. Campinas: UNICAMP, Instituto de Filosofia e Ciências Humanas, 2005

BIONDI, Pablo. Acumulação por espoliação e direitos sociais: crítica do reformismo. Revista Crítica do Direito, n. 1, v. 13, jul. 2011. Disponível em: <http://www.criticadodireito.com.br/edicao-atual-numero-1-volume-13/acumulacaopor-espoliacao-e-direitos-sociais-critica-do-reformismo>. Acesso em: 31 dez. 2011.

BOBBIO, Norberto. A era dos direitos. Tradução de Carlos Nelson Coutinho. Rio de Janeiro: Campus, 1992.

- Liberalismo e democracia, 6. ${ }^{a}$ ed.. Tradução de Marco Aurélio Nogueira. São Paulo: Brasiliense, 2005.

O futuro da democracia: uma defesa das regras do jogo.

Tradução de Marco Aurélio Nogueira. Rio de Janeiro: Paz e Terra, 1986.

BOITO JR., Armando. Os problemas da análise poulantziana de Estado feudal. Crítica Marxista, São Paulo, n. 7, pp. 67-88, 1998.

CASTEL, Robert. As metamorfoses da questão social: uma crônica do salário. Tradução de Iraci D. Poleti. Petrópolis: Vozes, 1998.

CHAGAS, Juary. Sociedade de classe, direito de classe: uma perspectiva marxista e atual. São Paulo: Instituto José Luís e Rosa Sundermann, 2011.

CHESNAIS, François. A mundialização do capital. Tradução de Silvana Finzi Foá. São Paulo: Xamã, 1996. 
COMPARATO, Fábio Konder. A afirmação histórica dos direitos humanos, 7aㅡ. ed.. São Paulo: Saraiva, 2010.

Ética: direito, moral e religião no mundo moderno. São Paulo: Companhia das Letras, 2006.

CORREIA, Marcus Orione Gonçalves. Interpretação dos direitos fundamentais sociais, solidariedade e consciência de classe. In: CANOTILHO, J. J. Gomes; CORREIA, Marcus Orione Gonçalves; CORREIA, Érica Paula Barcha (Coord.). Direitos fundamentais sociais. São Paulo: Saraiva, 2010.

O conflito de princípios e as falácias da liberdade. Revista TRF 3. a Região, São Paulo, n. 107, pp. 48-55, maio e jun./2011

COUTINHO, Carlos Nelson. A democracia como valor universal: notas sobre a questão democrática no Brasil. São Paulo: Livraria Editora Ciências Humanas, 1980.

DIGUIT, Léon. Fundamentos do direito. Tradução de Eduardo Salgueiro. Porto Alegre: Sergio Antonio Fabris Editor, 2005.

DOBB, Maurice. A evolução do capitalismo. Tradução de Affonso Blacheyre. Rio de Janeiro: Zahar, 1965.

DWORKIN, Ronald. Levando os direitos a sério, 2. ${ }^{\text {a }}$ ed.. Tradução de Nelson Boeira. São Paulo: Martins Fontes, 2007.

EDELMAN, Bernard. La légalisation de la classe ouvrière, t. I: l'entreprise. Paris: Christian Bourgois, 1978.

. Le droit saisi par la photographie: élements pour une théorie marxiste du droit. Paris: Flammarion, 2001.

ENGELS, Friedrich. Anti-Dühring: filosofia, economia política, socialismo, 2ª . ed.. Rio de Janeiro: Paz e Terra, 1990. 
Do socialismo utópico ao socialismo científico, $8^{\text {a }}$ ed.. Tradução de Armandina Venâncio. São Paulo: Global editora, 1986.

ENGELS, Friedrich; KAUTSKY, Karl. O socialismo jurídico, 2. ${ }^{a}$ ed.. Tradução de Lívia Cotrim e Márcio Bilharinho Naves. São Paulo: Ensaio, 1995.

ESPING-ANDERSEN, Gosta. As três economias políticas do welfare state. Tradução de Dinah de Abreu Azevedo. Lua Nova, São Paulo, n. 24, set. 1991.

FAUSTO, Ruy. Marx: Lógica e Política: Investigações para uma reconstituição do sentido da dialética: tomo II. São Paulo: Brasiliense, 1987.

FERNANDES, Florestan. Apontamentos sobre a "Teoria do Autoritarismo". São Paulo: Hucitec, 1979.

HARVEY, David. Condição pós-moderna: uma pesquisa sobre as origens da mudança cultural, 16. a ed.. Tradução de Adail Ubirajara Sobral e Maria Stela Gonçalves. São Paulo: Edições Loyola, 2007.

. O enigma do capital: e as crises do capitalismo. Tradução de João Alexandre Peschanski. São Paulo: Boitempo, 2011.

O novo imperialismo, 3. ${ }^{a}$ ed. Tradução de Adail Sobral e Maria Stela Gonçalves. São Paulo: Edições Loyola, 2009.

HIRSCH, Joachim. Observações teóricas sobre o Estado burguês e sua crise. In: POULANTZAS, Nicos (org.). Estado em crise. Tradução de Maria Laura Viveiros de Castro. Rio de Janeiro: Graal, 1977.

. Teoria materialista do Estado: processos de transformação do sistema capitalista de Estado. Tradução de Luciano Cavini Martorano. Rio de Janeiro: Revan, 2010.

HOBSBAWM, Eric J.. A era das revoluções: Europa 1789-1848, 12ª . ed.. Tradução de Maria Tereza Lopes Teixeira e Marcos Penchel. Rio de Janeiro: Paz e Terra, 2000. 
. Era dos extremos: o breve século XX: 1914-1991, 2.. ed.. Tradução de Marcos Santarrita. São Paulo: Companhia das Letras, 2001.

KASHIURA JÚNIOR, Celso Naoto. Crítica da Igualdade Jurídica: contribuição ao pensamento jurídico marxista. São Paulo: Quartier Latin, 2009.

Dialética e forma jurídica - considerações acerca do método de Pachukanis. In: NAVES, Márcio Bilharinho (org.). 0 discreto charme do direito burguês: ensaios sobre Pachukanis. Campinas, SP: UNICAMP, Instituto de Filosofia e Ciências Humanas, 2009.

KURZ, Robert. Os últimos combates, 5. ํㅡ. ed.. Tradução de José Marcos Macedo. Petrópolis: Editora Vozes, 1998.

LENIN, Vladimir llitch. 0 Estado e a revolução: o que ensina o marxismo sobre o Estado e o papel do proletariado na revolução. Tradução revista por Aristides Lobo. São Paulo: Expressão Popular, 2007.

O imperialismo: fase superior do capitalismo, $4 .^{a}$ ed. Tradução de Olinto Beckerman. São Paulo: Global, 1987.

. Que fazer? Problemas candentes de nosso movimento. Tradução de Marcelo Braz. São Paulo: Expressão Popular, 2010.

LIEBKNECHT, Karl. Acerca da Justiça de Classe. Tradução de Emil von München. São Paulo: Instituto José Luís e Rosa Sundermann, 2002.

LOPES, José Reinaldo de Lima. Direito subjetivo e direitos sociais: o dilema do Judiciário no Estado Social de Direito. In: FARIA, José Eduardo Campos de Oliveira (org.). Direitos humanos, direitos sociais e justiça. São Paulo: Malheiros, 1994.

LOSURDO, Domenico. Democracia ou bonapartismo: triunfo e decadência do sufrágio universal. Tradução de Luiz Sérgio Henriques. Rio de Janeiro: Editora UFRJ; São Paulo: Editora UNESP, 2004. 
LUKÁCS, Georg. História e consciência de classe: estudos sobre a dialética marxista, 2. ${ }^{a}$ ed.. Tradução de Rodnei Nascimento. São Paulo: Martins Fontes, 2003.

LUXEMBURGO, Rosa. A socialização da sociedade. In: LOUREIRO, Isabel M.. Rosa Luxemburgo - Vida e obra, 3ª Ed. Tradução de Isabel Maria Loureiro. São Paulo: Expressão Popular, 2003.

. Reforma ou revolução?. Tradução de Lívio Xavier. São Paulo: Expressão Popular, 2007.

MARIUTTI, Eduardo Barros. Balanço do debate: a transição do feudalismo ao capitalismo. São Paulo: Hucitec, 2004.

MARX, Karl. A revolução antes da revolução. Tradução de José Barata-Moura e Eduardo Chitas. São Paulo: Expressão Popular, 2008.

. Contribuição à crítica da economia política, 2. ${ }^{a}$ ed.. Tradução de Florestan Fernandes. São Paulo: Expressão Popular, 2008.

. Manuscritos econômico-filosóficos. Tradução de Jesus Ranieri. São Paulo: Boitempo, 2009.

Miséria da Filosofia: Resposta à Filosofia da Miséria de Proudhon, 2ª ed.. Tradução de Torrieri Guimarães. São Paulo: Martin Claret, 2007.

O capital: crítica da economia política: livro I, vol. I, 26. a ed.. Tradução de Reginaldo Sant'Anna. Rio de Janeiro: Civilização Brasileira, 2008.

O capital: crítica da economia política: livro I, vol. II, 23. a ed. Tradução de Reginaldo Sant'Anna. Rio de Janeiro: Civilização Brasileira, 2009.

O capital: crítica da economia política: livro III, vol. IV, $26 .{ }^{a}$ ed.. Tradução de Reginaldo Sant'Anna. Rio de Janeiro: Civilização Brasileira, 2008.

O capital: crítica da economia política: livro III, vol. V, $26 .^{a}$ ed.. Tradução de Reginaldo Sant'Anna. Rio de Janeiro: Civilização Brasileira, 2008. 
. Para a questão judaica. Tradução de José Barata-Moura. São Paulo: Expressão Popular, 2009.

. Salário, preço e Iucro, 5ª ed.. Tradução de Silvio Donizete Chagas. São Paulo: Centauro, 2005.

MARX, Karl; ENGELS, Friedrich. A ideologia alemã: crítica da mais recente filosofia alemã em seus representantes Feuerbach, B. Bauer e Stirner, e do socialismo alemão em seus diferentes profetas. Tradução de Rubens Enderle, Nélio Schneider e Luciano Cavini Martorano. São Paulo: Boitempo, 2007.

Manifesto do Partido Comunista. Tradução de Sueli Tomazzini Barros Cassal. Porto Alegre: L\&PM, 2006.

MARSHALL, Thomas H. Cidadania, classe social e status. Tradução de Merton Porto Gadelha. Rio de Janeiro: Zahar, 1967.

MASCARO, Alysson Leandro. Crítica da legalidade e do direito brasileiro. São Paulo: Quartier Latin, 2003.

Introdução ao estudo do Direito. São Paulo: Quartier Latin, 2007.

MELO, Tarso Menezes de. Ambiguidade e resistência: direito, política e ideologia na neoliberalização constitucional. Tese (doutorado). São Paulo: USP, 2011.

MÉSZÁROS, István. Filosofia, ideologia e ciência social: ensaios de negação e afirmação. Tradução de Ester Vaisman. São Paulo: Boitempo, 2008.

- Para além do capital: rumo a uma teoria da transição. Tradução de Paulo Cezar Castanheira e Sérgio Lessa. São Paulo: Boitempo, 2009.

MIAILLE, Michel. Introdução crítica ao Direito, 3. a ed.. Tradução de Ana Prata. Lisboa: Estampa, 2005.

MISES, Ludwig von. O mercado. Tradução de Donald Stewart Jr.. Rio de Janeiro: José Olympio, 1987. 
NAVARRO, Sílvio; COSTA, Breno. Construtoras ajudam a eleger $54 \%$ dos novos congressistas. Folha de São Paulo, São Paulo, 07 nov. 2010. Disponível em $<$ http://www1.folha.uol.com.br/poder/826575-construtoras-ajudam-a-eleger-54-dosnovos-Congressistas.shtml>. Acesso em: 07 fev. 2010.

NAVES, Márcio Bilharinho. Direito, circulação mercantil e luta social. In: ALVES, Alaôr Caffé et al. Direito, sociedade e economia: leituras marxistas. Barueri: Manole, 2005.

. Marx: Ciência e Revolução. São Paulo: Quartier Latin, 2008.

. Marxismo e direito: um estudo sobre Pachukanis. São Paulo: Boitempo, 2008.

- Stalinismo e capitalismo. In: NAVES, Márcio Bilharinho (org.). Análise marxista e sociedade de transição. Campinas: UNICAMP, Instituto de Filosofia e Ciências Humanas, 2005.

NEUMANN, Franz. Estado democrático e Estado autoritário. Tradução de Luiz Corção. Rio de Janeiro: Zahar, 1969.

OLIVEIRA, Francisco de. Os direitos do antivalor: a economia política da hegemonia imperfeita. Petrópolis: Vozes, 1998.

PAINE, Thomas. Senso comum. Tradução de Ricardo Doninelli-Mendes. Porto Alegre: L\&PM, 2009.

PASUKANIS, Eugeny B. A teoria geral do direito e o marxismo. Tradução de Paulo Bessa. Rio de Janeiro: Renovar, 1989.

PAULANI, Leda M. Brasil Delivery: servidão financeira e estado de emergência econômico. São Paulo: Boitempo, 2008.

Seguridade social, regimes previdenciários e padrão de acumulação: uma nota teórica e uma observação sobre o Brasil. In: FAGNANI, Eduardo et alii. Previdência social: como incluir os excluídos. São Paulo: LTR, 2008. 
POULANTZAS, Nicos. Fascismo e ditadura. Tradução de João G. P. Quintela e M. Fernanda S. Granado. São Paulo: Martins Fontes, 1978.

O Estado, o poder, o socialismo, 4. ${ }^{a}$ ed.. Tradução de Rita Lima. São Paulo: Paz e Terra, 2000.

Poder político e classes sociais. Tradução de Francisco Silva. São Paulo: Martins Fontes, 1977.

PRADO, Eleutério. Desmedida do valor: crítica da pós-grande indústria. São Paulo: Xamã, 2005.

SAGRA, Alicia. A Internacional: um permanente combate contra o oportunismo e o sectarismo, 2. a ed.. Tradução de Paula Maffei. São Paulo: Instituto José Luís e Rosa Sundermann, 2010.

SILVA, Leandro Alves. Direito e marxismo: um encontro necessário. Disponível em: $\quad<$ http://www.fmauriciograbois.org.br/portal/impriminot.php?id sessao=8\&id

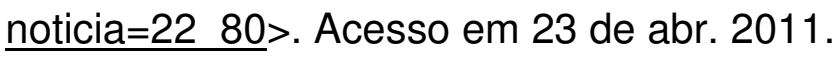

SIMÕES, Carlos Jorge Martins. Direito do trabalho e modo de produção capitalista. São Paulo: Símbolo, 1979.

SOUTO MAIOR, Jorge Luiz; CORREIA, Marcus Orione Gonçalves. O que é Direito Social?. In: CORREIA, Marcus Orione Gonçalves (org.). Curso de direito do trabalho. Vol. I. São Paulo: LTr, 2007.

SUPIOT, Alain. Critique du droit du travail, 2. ${ }^{a}$ ed. Paris: Quadrige/PUF, 2007.

THÉBAUD-MONY, Annie; DRUCK, Graça. Terceirização: a erosão dos direitos dos trabalhadores na França e no Brasil. In: DRUCK, Graça e FRANCO, Tânia (orgs.). A perda da razão social do trabalho: terceirização e precarização. São Paulo: Boitempo, 2007.

TROTSKY, Leon. A revolução traída. Tradução de Henrique Canary, Paula Maffei e Rodrigo Ricupero. São Paulo: Instituto José Luís e Rosa Sundermann, 2011. 
A teoria da revolução permanente. Tradução de Diego Siqueira e Hermínio Sacchetta. São Paulo: Instituto José Luís e Rosa Sundermann, 2010.

. O programa de transição para a revolução socialista. Tradução de Elisabeth Marie e Luiz Gustavo Soares. São Paulo: Instituto José Luís e Rosa Sundermann, 2008.

Questões do modo de vida. A moral deles e a nossa. Tradução de Diego Siqueira e Daniel Oliveira. São Paulo: Instituto José Luís e Rosa Sundermann, 2009.

TURCHETTO, Maria. As características específicas da transição ao comunismo. In: NAVES, Márcio Bilharinho (org.). Análise marxista e sociedade de transição. Campinas: UNICAMP, Instituto de Filosofia e Ciências Humanas, 2005.

VOLTAIRE. O preço da justiça, 2. a ed.. Tradução de Ivone Castilho Benedetti. São Paulo: Martins Fontes, 2006.

WALLERSTEIN, Immanuel. Capitalismo histórico e civilização capitalista. Tradução de Renato Aguiar. Rio de Janeiro: Contraponto, 2007.

ZOLO, Danilo. Teoria e crítica do Estado de Direito. In: COSTA, Pietro; ZOLO, Danilo. O Estado de Direito: História, teoria, crítica. Tradução de Carlo Alberto Dastoli. São Paulo, Martins Fontes, 2006. 